UNIVERSIDADE DE SÃO PAULO

INSTITUTO DE GEOCIÊNCIAS

\title{
MINERALOGIA E PETROLOGIA DE XENÓLITOS MANTÉLICOS DAS REGIÕES DE UBATUBA (SP) E MONTE CARMELO (MG): EVIDÊNCIAS DE FUSÃO PARCIAL E METASSOMATISMO NO MANTO SUPERIOR DO SUDESTE DO BRASIL
}

\author{
Vidyã Vieira de Almeida \\ Orientador: Prof. Dr. Valdecir de Assis Janasi \\ DISSERTAÇÃO DE MESTRADO \\ Programa de Pós-Graduação em Mineralogia e Petrologia \\ SÃO PAULO \\ 2009
}




\section{Resumo}

Estudos mineralógicos e petrológicos foram realizados em amostras de xenólitos do manto inclusos em dique de kaersutita lamprófiro de Ubatuba (SP) (Província Ígnea da Serra do Mar) e no Kimberlito Limeira 1 (Monte Carmelo, MG; Província Alcalina do Alto Paranaíba) utilizando petrografia e geoquímica de elementos maiores e traços em minerais por microssonda eletrônica e LA-ICPMS.

Os espinélio Iherzolitos de Ubatuba, para os quais foram estimadas temperaturas de equilíbrio entre 750 e $950^{\circ} \mathrm{C}$, representam um manto fértil, afetado por proporções variáveis, mas sempre moderadas de empobrecimento. Evidências de dois tipos de metassomatismo mantélico foram observadas em amostras distintas. Cristais de clinopiroxênio das amostras com evidências de empobrecimento prévio mais acentuado (maior Mg\# de olivina e piroxênios, menor Al e $\mathrm{Na}$ em piroxênios, pouco espinélio) mostram enriquecimento caracterizado por alta razão LILE/HFSE, atribuído a fluidos/fundidos provenientes de zonas de subducção. Em amostra de wehrlito pobre em espinélio, por outro lado, observa-se enriquecimento de LILE e HFSE no clinopiroxênio, sugestivo de interação com fluidos/fundidos alcalinos.

Os xenólitos do manto do Kimberlito Limeira 1 representam Iherzolitos e dunitos, com maior variedade mineralógica e textural, para os quais foram estimadas temperaturas de equilíbrio entre 760 e $820^{\circ} \mathrm{C}$. Evidências de metassomatismo modal mantélico são identificadas pela presença frequente de bolsões com concentração de minerais secundários, com notável enriquecimento de LILE e HFSE, em alguns casos com fases exóticas exclusivamente relacionadas a metassomatismo no manto superior. As assinaturas químicas das fases secundárias são semelhantes às presentes na suíte MARID e em peridotitos venulados metassomatizados de xenólitos de kimberlitos da África do Sul. Evidências petrográficas e químicas de descompressão (sugerindo a presença pretérita de granada) foram observadas em uma amostra afetada por enriquecimento com alta razão LILE/HFSE.

As diferentes evidências de processos de empobrecimento e metassomatismo observadas entre os dois grupos de xenólitos estudados (Ubatuba e Monte Carmelo), são indicativas da variabilidade lateral do manto superior de fácies espinélio do sudeste brasileiro, refletindo os processos geológicos (tectônicos e magmáticos) distintos vivenciados pelas duas regiões. 


\section{Abstract}

Mineralogical and petrological studies were conducted in mantle xenoliths included in a kaersutite lamprophyre dyke from Ubatuba (SP) (Serra do Mar Igneous Province), and in the Limeira 1 Kimberlite (Monte Carmelo, MG; Alto Paranaíba Alkalic Province), using petrography and major and trace element geochemistry in minerals by electron microprobe and LA-ICPMS.

The Ubatuba spinel Iherzolites, with equilibrium temperatures ranging from 750 to $950^{\circ} \mathrm{C}$, represent a fertlie mantle affected by variable but moderate depletion. Evidence of two types of mantle metasomatis were detected in different samples. Clinopyroxene crystals of the samples with evidence of stronger previous depletion (olivine and pyroxenes with higher Mg\#, pyroxenes with lower $\mathrm{Al}$ and $\mathrm{Na}$, few proportion of spinel) show enrichment with high LILE/HFSE, attributed to fluids/melts derived from subduction zone. On the other hand, a spinelpoor wehrlite shows a clinopyroxene with both LILE and HFSE enrichment, suggestive of interaction with alkaline fluids/melts.

The Limeira 1 mantle xenoliths correspond to Iherzolites and dunites showing more textural and mineralogical variety and equilibrium temperatures ranging from 760 to $820^{\circ} \mathrm{C}$. Modal metasomatism was identified by the presence of abundant pockets with concentration of LILE and HFSE-rich secondary minerals, including in some cases, exotic phases typical of upper mantle metasomatism. The chemical signature of the metasomatic minerals is similar to those found in MARID and in veined metasomatic peridotites from South Africa kimberlite xenoliths. Petrographic and chemical evidences of decompression (suggesting the former presence of garnet) were observed in a sample affected by enrichment with high LILE/HFSE.

The different evidences of depletion and enrichment processes observed in the two groups of xenoliths (Ubatuba and Monte Carmelo) indicate a lateral variability of the spinelfacies upper mantle in southeast Brazil, which may reflect the distinct tectonic and magmatic processes that affected these two regions. 


\section{Agradecimentos}

O desenvolvimento e a conclusão deste trabalho foram possíveis graças ao auxílio de várias pessoas às quais expresso meu profundo agradecimento.

Ao Prof. Dr. Valdecir de Assis Janasi, pela orientação, apoio, compreensão e estímulo durante todas as fases do trabalho.

Ao Prof. Dr. Darcy Pedro Svisero, colaborador do projeto, que cedeu parte de suas amostras de xenólitos do Kimberlito Limeira 1 e também contribuiu com sugestões e discussões sobre o tema.

Os dados de elementos traços em minerais por LA-ICPMS foram obtidos no Laboratório de Química do IGc-USP com a colaboração e auxílio de Sandra Andrade, Margareth Sugano Navarro e da Dra. Lucelene Martins. Análises químicas em minerais por Microssonda Eletrônica tiveram auxílio de Marcos Mansueto, enquanto análises e imagens no Microscópio Eletrônico de Varredura tiveram o apoio de Isaac Jamil Sayeg.

Ao pessoal da pós-graduação do IGc-USP, Liza, Adriana, Lucelene, Luana, Leandro, Vivian, Gabriel, Rogério, Félix, Carlos, Renato, Bruna, Felipe, Maurício, Rafael, Vinícius, John e Marta.

Agradeço a Luiz Antônio Chieregati e José Carlos Garcia da CPRM-Serviço Geológico do Brasil (Sureg-SP) pelo período parcial utilizado na dissertação, e os colegas de CPRM: Luiz Gustavo, Sérgio, Fabrizzio, Elizete, Viviane, Mônica, Márcio, Eduardo Longo, Eduardo Jorge, Vilmario, Andréa, Dinorá, Arivane e José da Costa.

Ao geólogo Vicente Sérgio da Costa (CPRM-SP), pesquisador de xenólitos do manto, que contribuiu com discussões sobre o tema.

Aos funcionários do IGc-USP, em especial Ana Paula Cabanal, Magali Rizzo, Tadeu, Maria Inês, Angélica, José Paulo, Henrique, Paulo, Luizinho e Cláudio (Laminação).

À Fundação de Amparo à Pesquisa do Estado de São Paulo (FAPESP) agradeço o suporte financeiro referente à bolsa de mestrado (processo 2006/01925-4) e ao projeto de auxílio à pesquisa (processo 2007/00635-5).

À CNPq agradeço o suporte financeiro referente a um período parcial de bolsa de mestrado.

O apoio incondicional dos meus pais, Mirian e Sidney, foi fundamental para o meu ingresso no mestrado e para a realização de todo o trabalho. Também agradeço minha irmã Ananda e meus sogros Lúcia e Jair pelo auxílio em várias etapas.

Ao meu marido, Frederico Meira Faleiros, pelo apoio em tudo, desde a redação do texto, petrografia e discussões sobre os mais diversos assuntos. Um agradecimento especial para o Frederico e nosso querido filho Samuel que nasceu no início do mestrado. 
Índice

1. INTRODUÇÃO__ 1

1.1. Objetivos e justificativas __ 2

1.2. Materiais e métodos 3

1.2.1. Pesquisa bibliográfica __ 3

1.2.2. Levantamentos de campo e amostragem __ 4

1.2.3. Análise petrográfica ___ 4

1.2.4. Microscopia eletrônica de varredura __ 4

1.2.5. Química mineral __ 4

1.2.6. Análise química de rocha total ___ 7

2. LEVANTAMENTO BIBLIOGRÁFICO __ 7

2.1. Xenólitos do manto___ 7

2.2. Registros de xenólitos do manto no Brasil ___ 11

3. XENÓLITOS DO LAMPRÓFIRO DA PRAIA VERMELHA (UBATUBA - SP) ___ 14

3.1. Situação geológica _r 14

3.2. Petrografia 17

3.2.1. Grupo 1: Espinélio Iherzolitos com textura protogranular___ 18

3.2.2. Grupo 2: Wehrlitos _ 24

3.2.3. Grupo 3: Fragmentos menores __ 27

3.2.4. Xenocristais/Fenocristais ___ 28

3.3. Química mineral _ 29

3.3.1. Olivina__ 29

3.3.2. Ortopiroxênio — 29

3.3.3. Clinopiroxênio

3.3.4. Espinélio _ 33

3.3.5. Análises semi-quantitativas por EDS em fases acessórias ___ 34

3.4. Geoquímica de elementos-traços em minerais

3.4.1. Residência dos elementos traços em espinélio peridotitos __ 35

3.4.2. Análises de elementos-traços por LA-ICPMS _ 36

3.5. Petrogênese _ 40

3.5.1. Estimativas de temperatura _ 40

3.5.2. Modelos de fusão em equilíbrio e fusão fracionada__ 42

3.6. Discussão — 44

4. XENÓLITOS DO KIMBERLITO LIMEIRA 1 (MONTE CARMELO- MG)___ 47

4.1. Situação geológica _ـ 47

4.2.Petrografia 49

4.2.1. Grupo 1: Espinélio peridotitos com textura protogranular __ 51

4.2.2. Grupo 2: Espinélio-flogopita peridotitos com texturas protogranular e transicional 55 
4.2.3. Grupo 3: Xenólitos com predominância de fases metassomáticas 67

4.2.4. Macrocristais/Xenocristais 73

4.3. Geoquímica de rocha total __ 73

4.4. Química Mineral__ 75

4.4.1. Olivina 75

4.4.2. Ortopiroxênio —— 75

4.4.3. Clinopiroxênio 77

4.4.4. Espinélio 79

4.4.5. Fases minerais metassomáticas __ 80

4.5. Análises de elementos traços por LA-ICPMS _ 93

4.6. Petrogênese _ 97

4.6.1. Estimativas de temperatura $\quad 97$

4.6.2. Elementos traços em rocha total vs. elementos traços em clinopiroxênio ___ 98

4.6.3. Modelos de fusão em equilíbrio e fusão fracionada___ 98

4.7. Discussão 100

5. DISCUSSÃO INTEGRADA E CONSIDERAÇÕES FINAIS___ 103

6. REFERÊNCIAS BIBLIOGRÁFICAS 105

ANEXOS 


\section{Índice de Figuras}

\section{INTRODUÇÃO}

Figura 1: Mapas rodoviários com localização das áreas

\section{LEVANTAMENTO BIBLIOGRÁFICO}

Figura 2: Diagrama de classificação de Streckeisen (1976) para peridotitos e piroxenitos

Figura 3: Diagrama de P e T com as fácies plagioclásio, espinélio e granada

Figura 4: Localização de xenólitos mantélicos na América do Sul

\section{XENÓLITOS DO LAMPRÓFIRO DA PRAIA VERMELHA (UBATUBA - SP)}

Figura 5: Mapa com a localização do dique de lamprófiro na Praia Vermelha de Ubatuba (SP)

Figura 6: Feições de campo do dique de lamprófiro da Praia Vermelha (Ubatuba)

Figura 7: Seção delgada do lamprófiro encaixante

Figura 8: Diagrama de Streckeisen (1976) com classificação dos xenólitos de Ubatuba

Figura 9: Fotomontagem da lâmina do xenólito Ln9xm1

Figura 10: Cristal de clinopiroxênio esverdeado em contato com olivina

Figura 11: Fotomontagem do xenólito Ln9xm3

Figura 12: Fotomontagem do xenólito Ln9h

Figura 13: Borda de reação entre o xenólito Ln9xm3 e o lamprófiro encaixante

Figura 14: Cristais de ortopiroxênio, clinopiroxênio e olivina associada a material de alteração

Figura 15: Borda de reação do xenólito Ln9xm2 com o lamprófiro

Figura 16: Intercrescimento de clinopiroxênio e olivina no xenólito Ln9xm

Figura 17: Visão geral do xenólito Ln9g

Figura 18: Borda de reação rosada em cristal de ortopiroxênio do xenólito Ln9g

Figura 19: Xenocristais de ortopiroxênio e olivina no lamprófiro

Figura 20: Diagrama de Morimoto (1988) com classificação dos cristais de ortopiroxênio

Figura 21: Composições de núcleos de cristais de ortopiroxênio

Figura 22: Diagrama de Morimoto (1988) com classificação dos cristais de clinopiroxênio

Figura 23: Composições de núcleos de cristais de clinopiroxênio

Figura 24: Composições de cristais de espinélio

Figura 25: Diagrama ternário para cristais de espinélio

Figura 26: Imagem BSE de sulfeto de Fe e Ni do xenólito Ln9h

Figura 27: Razões LILE/HFS (La/Nb e La/Zr) dos cristais de clinopiroxênio

Figura 28: Padrões de elementos terras raras de cristais de clinopiroxênio

Figura 29: Padrões de elementos incompatíveis de cristais de clinopiroxênio

Figura 30: Curvas geradas por modelamentos de fusão em equilíbrio e fusão fracionada

Figura 31: Padrões de elementos incompatíveis previstos por fusão em equilíbrio e fracionada 


\section{XENÓLITOS DO KIMBERLITO LIMEIRA 1 (MONTE CARMELO-MG)}

Figura 32: Localização geográfica do Kimberlito Limeira 1

Figura 33: Exemplos de xenólitos estudados do Kimberlito Limeira 1

Figura 34: Diagrama de Streckeisen (1976) com a classificação dos xenólitos do Kimberlito Limeira 1

Figura 35: Fotomontagem do xenólito Klxm1

Figura 36: Cristal de ortopiroxênio com borda de alteração cor marrom acinzentada

Figura 37: Cristais de clinopiroxênio com concentração de trilhas de inclusões fluidas_

Figura 38: Detalhe na banda com ortopiroxênio, clinopiroxênio e espinélio

Figura 39: Fotomontagem do xenólito Klxm2

Figura 40: Neoblastos em microfraturas e no limite dos cristais de olivina

Figura 41: Clivagem proeminente e dobrada em cristal de olivina

Figura 42: Borda de alteração de cristal de ortopiroxênio com cristais fibrosos

Figura 43: Cristal de ortopiroxênio com inclusões de flogopita e clinopiroxênio

Figura 44: Contato irregular entre ortopiroxênio e clinopiroxênio

Figura 45: Bolsão zonado com clinopiroxênio, flogopita e minerais opacos

Figura 46: Cristal de flogopita dobrado

Figura 47: Cristal de flogopita no contato com o kimberlito

Figura 48: Relação entre clinopiroxênio, ortopiroxênio e olivina

Figura 49: Ortopiroxênio em contato com olivina

Figura 50: Relação entre olivina, clinopiroxênio e flogopita mais tardia

Figura 51: Fotomicrografia do xenólito KIxm4

Figura 52: Fotomontagem do xenólito Klxm6

Figura 53: Cristais de olivina com contatos poligonizados

Figura 54: Cristal poiquilítico de flogopita

Figura 55: Fotomontagem do xenólito Klxm3

Figura 56: Imagem BSE da massa policristalina de minerais opacos

Figura 57: Indicação das inclusões vermiformes de calcita

Figura 58: Inclusões de cristal euédrico, esverdeado em carbonato

Figura 59: Inclusões em carbonato

Figura 60: Inclusões e zoneamento em flogopita

Figura 61: Cristais de clinopiroxênio em contato interlobado

Figura 62: Cristal de olivina sem inclusões

Figura 63: Cristais de olivina no kimberlito

Figura 64: Padrões de elementos terras raras de análises de rocha total dos xenólitos e do Kimberlito Limeira 1

Figura 65: Padrões de elementos incompatíveis dos xenólitos e do Kimberlito Limeira 1

Figura 66: Diagrama de Morimoto (1988) com classificação dos cristais de ortopiroxênio

Figura 67: Composições de núcleos de cristais de ortopiroxênio

Figura 68: Diagrama de Morimoto (1988) com classificação dos cristais de clinopiroxênio

Figura 69: Composições de núcleos de cristais de clinopiroxênio

Figura 70: Composições de cristais de espinélio

Figura 71: Diagrama ternário para cristais de espinélio

Figura 72: Diagrama com membros finais de micas trioctaédricas

Figura 73: Diagrama $\mathrm{FeO} \times \mathrm{Al}_{2} \mathrm{O}_{3}$ com campos composicionais de micas

Figura 74: Detalhe de cristal de ilmenita com lamelas de cromita

Figura 75: Imagens BSE e de microscópio de luz transmitida mostrando cristal de cromita manteado por mathiasita

Figura 76: Imagem no microscópio de luz transmitida e imagem BSE com relação entre cromita, Ilmenita e mathiasita

Figura 77: $\mathrm{K}(\mathrm{A}) \times \mathrm{Fe}(\mathrm{M})$ de cristais de mathiasita 
Figura 78: Diagrama ternário com análises de mathiasita obtidas neste trabalho

Figura 79: Dados composicionais de mathiasita do xenólito Klxm2 projetados no diagrama de Haggerty (1995)

Figura 80: Imagem no microscópio de luz transmitida e BSE de cristal de ilmenita e lamelas de priderita

Figura 81: Imagem no microscópio de luz transmitida e BSE de priderita manteada por ilmenita

Figura 82:Relação inversamente proporcional entre Ti (M) e Fe (M)

Figura 83: Dados composicionais de priderita do xenólito Klxm3 projetados no diagrama de Haggerty (1995)

Figura 84: Razões LILE/HFS dos cristais de clinopiroxênio

Figura 85: Padrões de elementos terras raras de cristais de clinopiroxênio

Figura 86: Padrões de elementos incompatíveis de cristais de clinopiroxênio

Figura 87: Curvas geradas por modelamentos de fusão em equilíbrio e fracionada

Figura 88: Padrões de elementos incompatíveis previstos por fusão em equilíbrio e

fracionada

\section{Índice de Tabelas}

Tabela 1: Padrões químicos utilizados nas análises químicas por microssonda eletrônica

Tabela 2: Limites de detecção médios e desvio padrão de análises por LA-ICPMS

Tabela 3: Caracterização geral dos xenólitos maiores de Ubatuba

Tabela 4: Temperaturas estimadas para xenólitos de Ubatuba

Tabela 5: Quadro comparativo com as características gerais dos xenólitos de Ubatuba

Tabela 6: Caracterização geral dos xenólitos de Monte Carmelo

Tabela 7: Temperaturas estimadas para xenólitos de Monte Carmelo

Tabela 8: Quadro comparativo com as características gerais dos xenólitos do Kimberlito Limeira 1 


\section{INTRODUÇÃO}

O conhecimento da composição e estrutura do manto superior é tema fundamental para diversas áreas das geociências, com implicações diretas para a geração de magmas de qualquer natureza, sejam eles graníticos, basálticos ou alcalinos. Mesmo no caso do magmatismo granítico, volumetricamente mais abundante na crosta continental, e onde a contribuição da reciclagem de material crustal é geralmente importante, um componente derivado do manto tem sido identificado na significativa maioria dos casos (e.g. Barbarin, 1999; Patiño-Douce, 1999).

Embora contribuições provenientes da petrologia ígnea (a partir da geoquímica e das estimativas das condições de geração dos magmas de derivação mantélica) e da geofísica (através de métodos sísmicos, gravimétricos, magneto-telúricos e outros) ofereçam suporte fundamental para o conhecimento da estrutura da litosfera e astenosfera terrestres, a caracterização do manto superior continental de uma determinada região é criticamente dependente da amostragem direta, apenas possível com o estudo de xenólitos trazidos por certos tipos de magma de ascensão rápida (e.g., kimberlitos, lamproítos, lamprófiros e basaltos alcalinos).

Desde os anos 1970 o estudo de xenólitos mantélicos tem trazido importantes contribuições para os modelos de evolução do manto, permitindo estimativas diretas de sua composição mineralógica, química e isotópica e de sua variabilidade vertical (pela estimativa da composição, profundidade e temperatura de cristalização de diferentes xenólitos) e lateral (pela comparação entre xenólitos amostrados em diferentes locais). Grande parte dos progressos alcançados desde então estão reunidos nas monografias específicas de Nixon $(1980,1987)$, Dawson (1980) e Pearson et al. (2003) bem como em inúmeros artigos distribuídos na literatura geológica recente.

São poucos os registros de ocorrências conhecidas de xenólitos do manto no sudeste brasileiro, o que constitui um sério limitante para modelos petrológicos e geofísicos nessa vasta região. Assim é que o papel do manto litosférico ou astenosférico na geração do magmatismo basáltico (e.g. Hawkesworth et al., 1988; Peate \& Hawkesworth, 1996), alcalino (CominChiaramonti et al., 1997) e granítico (e.g. Janasi et al., 1993; Wernick \& Menezes, 2001) é tema amplamente debatido, mas que claramente demanda o conhecimento direto desses reservatórios.

O presente estudo propõe contribuir para o conhecimento do manto superior do sudeste brasileiro através do estudo petrográfico e geoquímico de detalhe de xenólitos do manto que ocorrem em intrusões subvulcânicas de duas regiões distintas: (a) Kimberlito Limeira 1, localizado $26 \mathrm{~km}$ a norte da cidade de Monte Carmelo (MG) e $25 \mathrm{~km}$ a sudoeste de 
Coromandel (MG) (Figura 1) e (b) Dique de kaersutita lamprófiro da Praia Vermelha, Ubatuba (SP) (Figura 1).

A
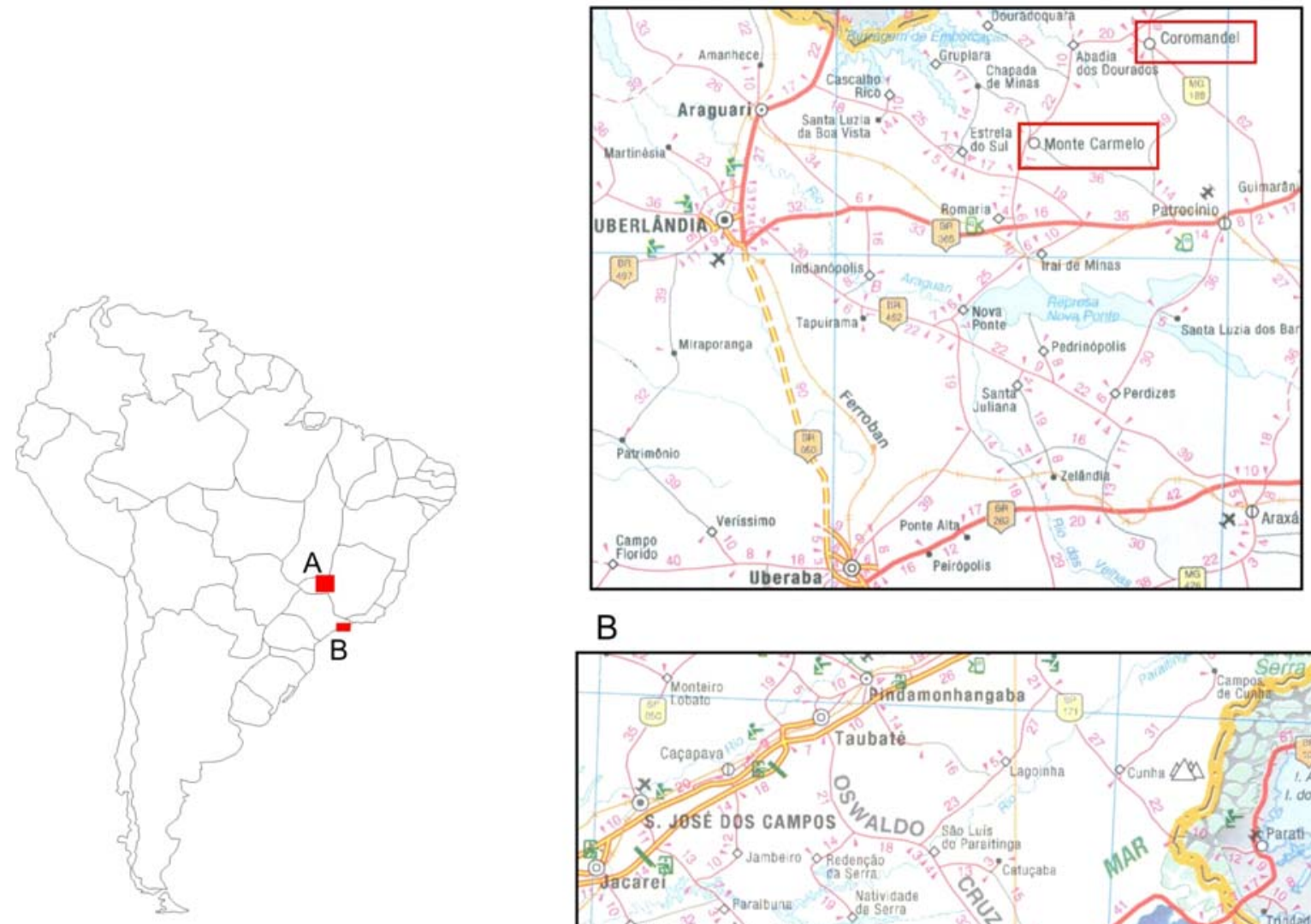

B

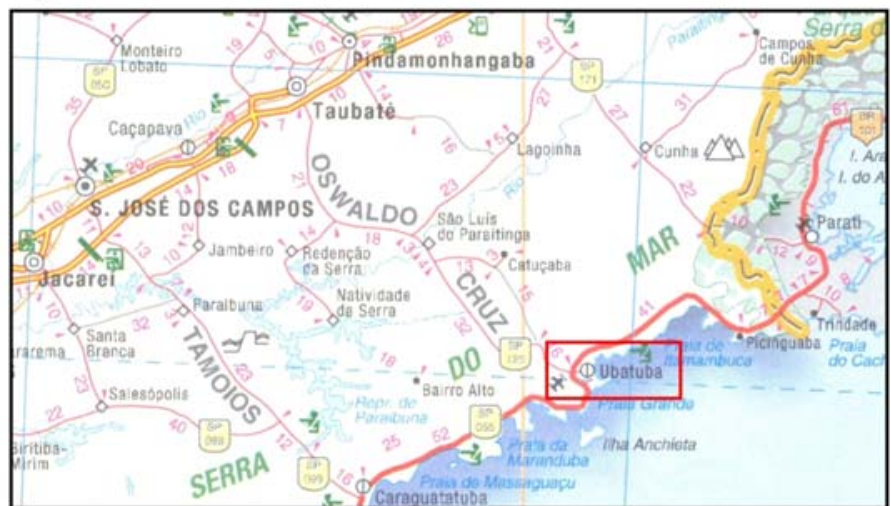

Figura 1: Mapas rodoviários com localização das cidades de Monte Carmelo (A), Coromandel (A) e Ubatuba (B).

\subsection{Objetivos e justificativas}

Xenólitos do manto são considerados como únicas amostras diretas dos reservatórios mais importantes dos quais são derivados os magmas que constituem a crosta continental terrestre. No caso do sudeste brasileiro, as únicas ocorrências conhecidas e estudadas com algum detalhe são as da região de Coromandel e Monte Carmelo (MG) (e.g. Leonardos et al., 1993; Svisero et al., 1984, Meyer \& Svisero, 1991; Carvalho, 1997) e mais recentemente de Córrego da Cachoeira (MG) (e.g. Costa et al., 2008).

O presente trabalho foi estimulado pela descoberta de xenólitos de espinélio Iherzolito no Estado de São Paulo (Janasi et al., 2006), e pela possibilidade de obter microanálises de elementos traços nos minerais dessas rochas por LA-ICPMS, recém implantado no IGc-USP, e cujo potencial na caracterização e identificação dos processos evolutivos registrados em 
xenólitos do manto tem sido largamente reconhecido (e.g., Griffin et al., 1996; Norman et al., 1998, Eggins et al., 1998).

O estudo de xenólitos equivalentes provenientes do Kimberlito Limeira 1, cedidos pelo Prof. Dr. Darcy Pedro Svisero, colaborador deste projeto, permitiu comparar as duas ocorrências, ambas de fácies espinélio, contribuindo para uma avaliação de variações laterais no manto do sudeste do Brasil. Análises in situ de elementos traços não foram até o momento reportadas na literatura para minerais de xenólitos da região de Monte Carmelo, de modo que os resultados aqui obtidos trazem contribuição importante para a caracterização desse material, com implicações diretas para o magmatismo alcalino da Província do Alto Paranaíba ou Minas-Goiás (e.g. Gibson et al., 1995; Araújo et al., 2001)

Os principais objetivos deste trabalho são:

a) Estudo petrográfico de detalhe das amostras mais favoráveis e caracterização textural, mineralógica e modal dos tipos litológicos existentes nas suítes de xenólitos de Limeira 1 e Ubatuba;

b) Determinação da composição química dos minerais constituintes em termos de elementos maiores e menores (por microssonda eletrônica) e traços, incluindo os elementos terras raras (por LA-ICPMS);

c) Determinação das condições de equilíbrio $(P, T)$ e dos processos evolutivos (e.g. extração de magmas, metassomatismo associado à interação com fluidos/ fundidos) registrados nos xenólitos;

d) Discussão acerca da natureza e evolução do manto no sudeste do Brasil e comparação das duas ocorrências a partir dos dados novos obtidos.

\subsection{Materiais e métodos}

Foram analisadas amostras de xenólitos do manto previamente coletadas por Darcy Pedro Svisero (no Kimberlito Limeira 1) e Valdecir de Assis Janasi (no dique lamprofírico de Ubatuba). Tratam-se, em ambos os casos, de fragmentos com dimensões máximas da ordem de 1 a $10 \mathrm{~cm}$ (em média menores em Ubatuba).

\subsubsection{Pesquisa bibliográfica}

A pesquisa bibliográfica foi realizada procurando cobrir a literatura nacional sobre o tema. Especial atenção foi dada à literatura internacional recente, utilizada para orientar o tratamento e interpretação dos resultados. 


\subsubsection{Levantamentos de campo e amostragem}

Os levantamentos de campo e amostragem necessários para a dissertação foram realizados pelo Prof. Dr. Valdecir de Assis Janasi (xenólitos de Ubatuba) e Prof. Dr. Darcy Pedro Svisero (xenólitos de Monte Carmelo).

\subsubsection{Análise petrográfica}

O estudo de seções delgadas ao microscópio petrográfico de luz transmitida e refletida foi realizado no Instituto de Geociências da Universidade de São Paulo com a finalidade de caracterizar os minerais dos xenólitos e as relações texturais. Algumas estimativas modais foram feitas, nos xenólitos maiores, utilizando charriot e contador de pontos. Imagens fotográficas digitais compostas da área total amostrada dos xenólitos foram obtidas com 0 intuito de visualizar de modo integrado e com o máximo de detalhe os fragmentos de xenólito estudados.

\subsubsection{Microscopia eletrônica de varredura}

Imagens de elétrons retroespalhados (BSE) e análises semi-quantitativas foram feitas no Microscópio Eletrônico de Varredura (MEV) do Departamento de Geologia Sedimentar e Ambiental do Instituto de Geociências da Universidade de São Paulo a fim de melhor caracterizar as fases acessórias e localizar possíveis zoneamentos composicionais. $O$ equipamento LEO-440I foi utilizado e apresenta capacidade de geração de imagens com aumentos de $5 x$ a 250.000x dependendo do detector e da amostra. As microanálises foram feitas por meio de espectômetro de energia dispersiva de raios-x Oxford com voltagem de aceleração de 20 kv.

\subsubsection{Química mineral}

\section{Elementos maiores por microssonda eletrônica}

As análises químicas em fases minerais foram realizadas no Laboratório de Microssonda Eletrônica do Departamento de Mineralogia e Getectônica do Instituto de Geociências da Universidade de São Paulo. Foi utilizado o equipamento da marca JEOL, modelo JXA-8600, composto por cinco espectômetros de dispersão de comprimento de onda 
(WDS) cada um com dois cristais analisadores, com automação de fabricação NORAN e sistema Voyager 3.6.1. Correções de efeitos de matriz foram feitas com o procedimento PROZA (Bastin et al., 1984).

As seções delgadas polidas analisadas foram metalizadas com carbono em câmara de vácuo.

As análises quantitativas foram feitas com $15 \mathrm{kv}$ de voltagem de aceleração e $20 \mathrm{nA}$ de corrente do feixe eletrônico com diâmetro de $5 \mu \mathrm{m}$. Diâmetro de $10 \mu \mathrm{m}$ foi utilizado em cristais com finas lamelas. Os padrões químicos utilizados nas análises de piroxênios, micas e titanatos encontram-se na Tabela 1. Os dados obtidos foram tratados para o cálculo das fórmulas estruturais das fases minerais analisadas e lançados em diagramas classificatórios e de variação catiônica utilizando os programas Minpet 2.02 e Excel.

Tabela 1: Padrões químicos utilizados nas análises por microssonda eletrônica em piroxênio, mica (flogopita) e titanatos.

\begin{tabular}{|c|c|c|c|}
\hline \multicolumn{2}{|c|}{ Piroxênio e mica } & \multicolumn{2}{|r|}{ Titanatos } \\
\hline Elemento & Padrão & Elemento & Padrão \\
\hline Si & Wollastonita & $\mathbf{N b}$ & Nióbio metálico \\
\hline $\mathrm{Ti}$ & Rutilo & Si & Wollastonita \\
\hline Al & Anortita & $\mathrm{Ti}$ & Rutilo \\
\hline $\mathrm{Fe}$ & Olivina & $\mathrm{Zr}$ & Zircônio metálico \\
\hline Mn & Olivina & Al & Anortita \\
\hline Mg & Diopsídio & $\mathrm{Cr}$ & Óxido de Crômio Cr2O3 \\
\hline $\mathrm{Ca}$ & Wollastonita & Mg & Diopsídio \\
\hline $\mathrm{Na}$ & Albita & $\mathrm{Ca}$ & Wollastonita \\
\hline K & Asbeto & Mn & Olivina \\
\hline $\mathbf{F}$ & Apatita & $\mathrm{Fe}$ & Olivina \\
\hline $\mathrm{Cl}$ & Fosfato de Cloro sintético & $\mathrm{Sr}$ & Silicato de Sr (SRAN) \\
\hline \multirow[t]{5}{*}{$\mathrm{Ba}$} & Silicato de Bário natural & $\mathrm{Ba}$ & Silicato de Bário natural \\
\hline & & $\mathrm{Na}$ & Albita \\
\hline & & K & Asbeto \\
\hline & & La & Vidro terras raras REE3 \\
\hline & & $\mathrm{Ce}$ & Vidro terras raras REE3 \\
\hline
\end{tabular}

\section{Elementos traços por LA-ICPMS}

Análises químicas de elementos traços em minerais constituem uma ferramenta fundamental no estudo de xenólitos do manto, e seu uso, inicialmente limitado a um pequeno número de laboratórios dotados de microssonda iônica (SIMS), tem ganhado grande impulso 
com a implantação de espectrômetros ICP-MS dotados de amostradores por "laser ablation". O interesse pela análise de elementos traços reflete não apenas a possibilidade de determinar com precisão a composição de diversos elementos incompatíveis de grande significado na petrologia de magmas derivados do manto (e.g. ETR, Nb, Ta, Th, $\mathrm{U}$ etc), mas também a grande vantagem de identificar zoneamentos químicos que muitas vezes podem ser preservados devido aos baixos coeficientes de difusão desses elementos em algumas fases minerais. Além de estimativas adicionais e/ou mais precisas de parâmetros físico-químicos como temperatura e pressão, os dados obtidos por LA-ICPMS permitem estimar o controle de processos como a fusão parcial e extração de fundidos e a adição de fluidos/fundidos metassomáticos sobre a composição do manto, e também calcular a partição dos elementos traços entre as fases minerais (e.g. Norman et al., 1998, Bianchinni et al., 2007, Witt-Eickshen et al., 2005, Eggins et al., 1998, Fodor et al., 2002).

O amostrador "laser ablation" de $216 \mathrm{~nm}$ marca New-Wave foi implantado em abril de 2006 no espectrômetro quadrupolo ICP-MS Perkin-Elmer modelo ELAN-600 dotado de uma célula de reação dinâmica, em rotina no Laboratório de ICP do Instituto de Geociências desde o ano de 2004. As rotinas de análise permitem alcançar limites de detecção da ordem de subppm para a maior parte dos elementos traços nos minerais de interesse, com resolução espacial da ordem de 20 a $40 \mu \mathrm{m}$. O sinal produzido pelos íons amostrados é quantitativamente estimado a partir da calibração contra materiais de referência certificados, que incluem um padrão externo e ainda um padrão interno (um elemento químico cuja concentração no volume amostrado é conhecida de modo independente, e.g. Jackson et al.,1992).

Foram analisados cristais de clinopiroxênio, ortopiroxênio e olivina dos xenólitos, utilizando-se como padrões químicos a composição de vidros artificiais (NIST-610) e como controle de qualidade vidro de basalto $(\mathrm{BCR})$. Os diâmetros dos spots utilizados nas análises variaram de 20 a $40 \mu \mathrm{m}$. Como padrões internos foram utilizados teores de $\mathrm{CaO}$, obtidos por microssonda eletrônica, para normalização das análises de clinopiroxênio, e MgO para as de ortopiroxênio e olivina.

Os limites de detecção médios por elemento, juntamente com o desvio padrão, de análises em materiais de referência (BCR-2G, BHVO-2 e BIR-1G) são mostrados na Tabela 2. Os valores dos limites de detecção obtidos nas análises dos minerais dos xenólitos foram por vezes menores em relação aos mostrados na Tabela 2 e mostraram variações entre os minerais. 
Tabela 2: Limites de detecção médios (LD) (em ppm) e desvio padrão (S) obtidos em análises em materiais de referência.

\begin{tabular}{|c|c|c|c|c|c|c|c|c|}
\hline Elemento & LD & $\bar{S}$ & Elemento & LD & $\bar{s}$ & Elemento & LD & $\bar{S}$ \\
\hline${ }^{7} \mathrm{Li}$ & 0,53 & 0,101 & ${ }^{88} \mathrm{Sr}$ & 0,050 & 0,008 & ${ }^{159} \mathrm{~Tb}$ & 0,030 & 0,003 \\
\hline${ }^{9} \mathrm{Be}$ & 3,05 & 0,264 & & 0,040 & 0,007 & ${ }^{163} \mathrm{Dy}$ & 0,12 & 0,011 \\
\hline${ }^{25} \mathrm{Mg}$ & 1,40 & 0,267 & ${ }^{90} \mathrm{Zr}$ & 0,07 & 0,014 & ${ }^{165} \mathrm{Ho}$ & 0,030 & 0,004 \\
\hline${ }^{31} \mathrm{P}$ & 19,74 & 2,973 & ${ }^{93} \mathrm{Nb}$ & 0,050 & 0,006 & ${ }^{166} \mathrm{Er}$ & 0,09 & 0,015 \\
\hline${ }^{42} \mathrm{Ca}$ & 0,03 & 0,011 & 95 Mo & 0,38 & 0,053 & ${ }^{169} \mathrm{Tm}$ & 0,030 & 0,002 \\
\hline${ }^{45} \mathrm{Sc}$ & 0,60 & 0,079 & ${ }^{118} \mathrm{Sn}$ & 0,70 & 0,081 & ${ }^{173} \mathrm{Yb}$ & 0,17 & 0,034 \\
\hline${ }^{49} \mathrm{Ti}$ & 2,09 & 0,182 & ${ }^{121} \mathrm{Sb}$ & 0,13 & 0,018 & ${ }^{175} \mathrm{Lu}$ & 0,030 & 0,005 \\
\hline${ }^{51} \mathrm{~V}$ & 0,45 & 0,089 & ${ }^{133} \mathrm{Cs}$ & 0,040 & 0,005 & ${ }^{179} \mathrm{Hf}$ & 0,20 & 0,012 \\
\hline${ }^{52} \mathrm{Cr}$ & 2,43 & 0,202 & ${ }^{137} \mathrm{Ba}$ & 0,27 & 0,050 & ${ }^{181} \mathrm{Ta}$ & 0,030 & 0,004 \\
\hline${ }^{55} \mathrm{Mn}$ & 0,61 & 0,281 & ${ }^{139} \mathrm{La}$ & 0,040 & 0,005 & ${ }^{208} \mathrm{~Pb}$ & 0,090 & 0,009 \\
\hline${ }^{59} \mathrm{Co}$ & 0,11 & 0,018 & ${ }^{140} \mathrm{Ce}$ & 0,030 & 0,007 & ${ }^{232} \mathrm{Th}$ & 0,030 & 0,001 \\
\hline${ }^{60} \mathrm{Ni}$ & 0,52 & 0,085 & ${ }^{141} \mathrm{Pr}$ & 0,030 & 0,004 & ${ }^{238} U$ & 0,030 & 0,004 \\
\hline${ }^{65} \mathrm{Cu}$ & 0,55 & 0,052 & ${ }^{143} \mathrm{Nd}$ & 0,23 & 0,031 & & & \\
\hline${ }^{66} \mathrm{Zn}$ & 1,43 & 0,313 & ${ }^{147} \mathrm{Sm}$ & 0,19 & 0,031 & & & \\
\hline${ }^{71} \mathbf{G a}$ & 0,19 & 0,056 & ${ }^{151} \mathrm{Eu}$ & 0,060 & 0,009 & & & \\
\hline${ }^{85} \mathrm{Rb}$ & 0,11 & 0,020 & ${ }^{155} \mathrm{Gd}$ & 0,24 & 0,050 & & & \\
\hline
\end{tabular}

\subsubsection{Análise química de rocha total}

Foram feitas análises químicas de rocha total dos xenólitos de maior volume do Kimberlito Limeira 1 no Laboratório de ICP do Instituto de Geociências da Universidade de São Paulo. Os resultados foram comparados com dados químicos existentes na literatura (Carlson et al., 2007). As metodologias utilizadas foram ICP-OES para os elementos maiores (após abertura por fusão alcalina; cf. metodologia em Janasi et al., 1995) e ICP-MS para os elementos traços (após abertura por ataque ácido; cf. metodologia em Navarro et al., 2008).

\section{LEVANTAMENTO BIBLIOGRÁFICO}

\subsection{Xenólitos do manto}

"Xenólitos do manto" são todas as inclusões minerais ou de rocha com presumida derivação mantélica encontradas em rocha encaixante de origem vulcânica (Pearson et al, 2003). Pearson et al. (2003) classifica as ocorrências desses xenólitos com base no seu ambiente tectônico: oceânico ou continental. Os xenólitos de ambiente continental podem ser subdivididos pela idade e história tectônica da área. De forma geral, xenólitos de áreas estáveis cratônicas e circum-cratônicas são encontrados em kimberlitos e rochas relacionadas (e.g. orangeitos, lamproitos) enquanto os de áreas não cratônicas ocorrem em basaltos alcalinos, nefelinitos, melilititos, lamprófiros e relacionados (minetes, monchiquitos e alnoitos). De acordo 
com Dawson (1980) xenólitos mantélicos em kimberlitos podem ser divididos em cinco grupos principais:

-Grupo da suíte peridotítica-piroxenítica.

-Grupo de eclogitos e grospyditos.

-Grupo de peridotitos metassomatizados ricos em anfibólio e/ou mica.

-Grupo da suíte MARID e glimmeritos.

-Grupo de miscelânea de xenólitos.

O primeiro grupo (suíte peridotítica-piroxenítica) geralmente predomina em volume sobre os demais no entanto, ocorrem algumas raras intrusões onde eclogitos compreendem grande proporção dos xenólitos (e.g. kimberlito Roberts Victor, África do Sul) (Dawson, 1980).

As rochas da suíte peridotítica-piroxenítica são Iherzolitos, harzburgitos, dunitos, websteritos e piroxenitos. As nomenclaturas são baseadas na proporção modal de olivina, ortopiroxênio e clinopiroxênio de acordo com a nomenclatura da IUGS proposta por Streckeisen (1976) (Figura 2). Peridotitos, por definição, apresentam mais de $40 \%$ de olivina e proporções menores de orto e clinopiroxênio. Uma fase aluminosa (plagioclásio, espinélio ou granada) pode estar presente dependendo da pressão de equilíbrio e define a fácies (plagioclásio, espinélio ou granada) de onde o xenólito foi amostrado (Figura 3) (Pearson et al., 2003).

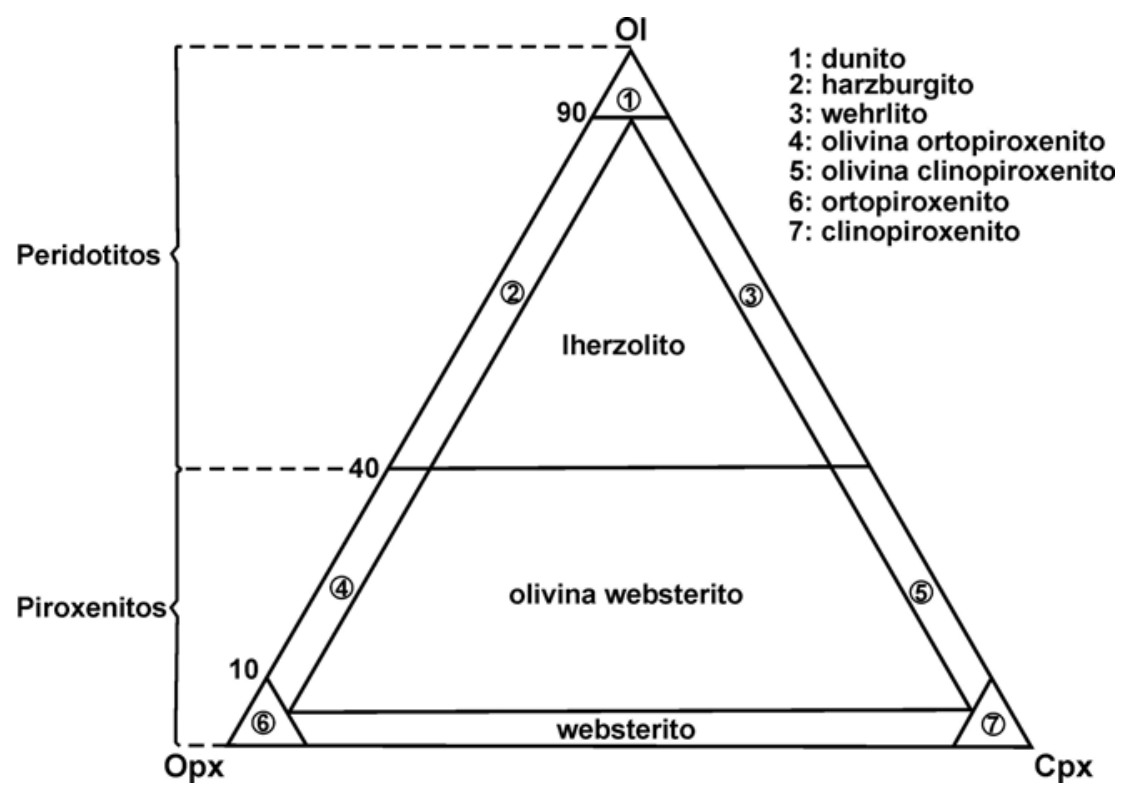

Figura 2: Diagrama de classificação de Streckeisen (1976) para peridotitos e piroxenitos. 


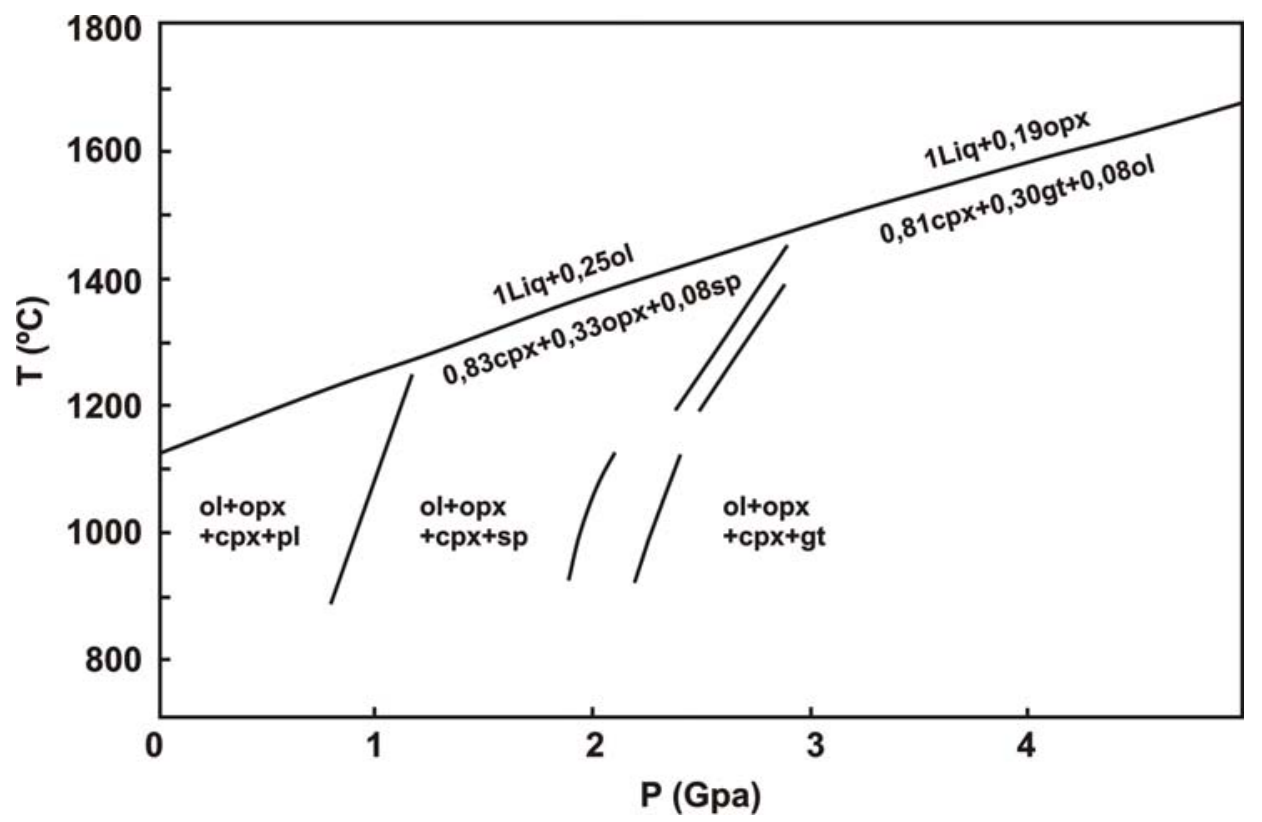

Figura 3: Diagrama de pressão e temperatura mostrando os solidus (Hirschmann, 2000) e os limites das fases (Koga et al., 1999) que definem as fácies plagioclásio (pl), espinélio (sp) e granada (gt) de peridotitos. Extraído de Pearson et al. (2003).

As texturas de xenólitos de peridotitos e piroxenitos são bastante variáveis. Como tectonitos metamórficos, as texturas refletem a temperatura, pressão e esforço diferencial do momento em que são acidentalmente coletados e transportados pelo magma (Pearson et al., 2003). O tamanho dos grãos, orientação e interrelação entre as fases minerais são critérios utilizados na classificação. Nesse trabalho optou-se pela classificação textural de Mercier \& Nicolas (1975) bastante utilizada em xenólitos de outras partes do mundo, na qual são definidas texturas: protogranular (i), porfiroclástica (ii), equigranular (iii) e texturas transicionais entre esses tipos. Em (i) a granulação geral é grossa e os contatos entre os cristais são retos a levemente curvados. Segundo Pearson et al. (2003), essa textura é desenvolvida por esforços diferenciais muito pequenos e constantes por milhões de anos na litosfera. Com um alto esforço diferencial ou fluxo plástico, a textura protogranular evolui para a textura porfiroclástica (ii) identificada pela presença de mais de $50 \%$ de matriz composta por pequenos neoblastos de olivina e porfiroclastos que podem ser de olivina, ortopiroxênio, granada e espinélio. A recristalização desta última textura evolui para a textura equigranular (iii) com granulação fina, onde os cristais apresentam mesma dimensão e os contatos são retos e formam ângulos de $120^{\circ}$. Mercier \& Nicolas (1975) subdividem esta textura em dois subtipos: textura equigranular tabular e equigranular em mosaico. Na primeira, boa parte dos cristais estão orientados e definem uma forte foliação. Na segunda, ocorre pouca orientação dos cristais. Cumpre ressaltar que existem outras classificações texturais como a de Harte (1977), também amplamente utilizada. 
O segundo grupo de xenólitos mantélicos de Dawson (1980) corresponde aos eclogitos e grospyditos. Eclogitos são rochas de granulação grossa compostas principalmente por granada, clinopiroxênio e um número limitado de fases acessórias como: coesita, escapolita, ortopiroxênio, olivina, anfibólio, quartzo, cianita, flogopita, rutilo, ilmenita, grafita e diamante. Grospyditos são um tipo especial de eclogito peraluminoso cuja principal diferença com cianita eclogito é a presença de granada com mais de $50 \%$ da molécula Grossulária (Dawson, 1980).

Os peridotitos metassomatizados compõem o terceiro grupo de xenólitos e representam peridotitos com evidência de formação de novos minerais, geralmente flogopita, ilmenita, rutilo, sulfetos, richterita e carbonato, por interação dos minerais pré-existentes com fluidos/fundidos. Segundo Harte (1987) a formação desses novos minerais é evidência de metassomatismo modal, mas também pode ocorrer o metassomatismo por enriquecimento dos cristais préexistentes por elementos maiores, menores e traços na ausência do metassomatismo modal, e também enriquecimento exclusivamente de elementos traços também sem envolvimento de formação de novos minerais, nomeado por Dawson (1982) de metassomatismo críptico.

Xenólitos de glimmeritos e da suíte MARID compõem o quarto grupo de xenólitos. O termo "glimmerito" é utilizado para xenólitos compostos dominantemente por flogopita e com proporções variáveis de anfibólio, clinopiroxênio, ilmenita, rutilo, apatita e olivina (Dawson, 1980). Aoki (1974) e Dawson \& Smith (1977) encontraram variações consideráveis na química dos minerais deste tipo de xenólito dos kimberlitos sul-africanos. Dawson \& Smith, particularmente, reconheceram a suíte MARID dentre os xenólitos. Esta consiste em xenólitos com variadas proporções de flogopita, anfibólio (K-richterita), rutilo, ilmenita e diopsídio com composições peculiares. Dawson \& Smith (1977) consideraram que a suíte MARID representa rochas que cristalizaram de um magma similar ao kimberlito em um ambiente oxidante do manto superior. A presença de anfibólio restringe a profundidade até aproximadamente 100 $\mathrm{km}$.

O grupo "miscelânea de xenólitos" de Dawson (1980) se refere a xenólitos de alkremitos e de rocha com ortopiroxênio e ilmenita em desequilíbrio (quenched orthopyroxene-ilmenite rock). O primeiro consiste em rochas de granulação grossa compostas por granada e espinélio verde escuro, enquanto o segundo é composto por xenólitos com intercrescimentos de ortopiroxênio e Mg ilmenita em macro-esferulitos.

Ocorrências de xenólitos em ambientes não cratônicos inclusos em basaltos alcalinos, nefelinitos, melilititos, lamprófiros e relacionados (minettes, monchiquitos e alnoitos) são subdivididas por Pearson et al. (2003) em cinco grupos:

-Grupo de Cr-diopsídio Iherzolitos.

-Grupo de Al-augita wehrlito-piroxenitos.

-Grupo de Granada piroxenito. 
-Grupo com metassomatismo modal.

-Megacristais.

Os três primeiros grupos se encaixam dentro do grupo da suíte peridotítica-piroxenítica de Dawson (1980) e para eles são usadas as mesmas classificações modais (Streckeisen, 1976) e texturais (Mercier \& Nicolas, 1975).

O grupo de Cr-diopsídio Iherzolitos apresenta xenólitos dominantemente de fácies espinélio (Al ou Cr-espinélio), porém também compreendem xenólitos de fácies granada e fácies granada-espinélio (e.g. Vitim, lonov et al. 1993a). Este grupo também compreende harzburgitos, ortopiroxenitos, clinopiroxenitos, websteritos e wehrlitos. O grupo de Al-augita wehrlito-piroxenitos compreende rochas ricas em clinopiroxênio portadoras de Al-espinélio e por vezes plagioclásio. Os minerais deste grupo apresentam menores $\mathrm{Mg \# ,} \mathrm{Cr} \#$ e maior $\mathrm{Ti}$ em relação aos xenólitos do primeiro grupo. O grupo de granada piroxenitos é menos abundante e compreende granada clinopiroxenitos e websteritos.

O grupo de xenólitos com metassomatismo modal compreende wehrlitos e clinopiroxenitos com mica e glimmeritos. Fases metassomáticas típicas incluem: pargasita/kaersutita, flogopita, apatita e óxidos (e.g. rutilo). Não são citadas ocorrências de xenólitos da suíte MARID.

O grupo de megacristais compreende cristais com mais de $1 \mathrm{~cm}$. Pearson et al. (2003) os divide em dois subgrupos: A e B. O subgrupo A compreende megacristais de Al-augita, Albronzita, olivina, kaersutita, piropo, pleonasto e plagioclásio, sendo que alguns podem ter cristalizado no magma encaixante. O subgrupo B compreende anortoclásio, mica, apatita, Fe$\mathrm{Na}$ salita, magnetita, ilmenita, zircão, rutilo, esfeno e córindon, todos com grande probabilidade de serem xenocristais.

Xenólitos de áreas não cratônicas tendem a representar profundidades de até $140 \mathrm{~km}$, enquanto os cratônicos podem ser provenientes de profundidades maiores, em parte superiores a $200 \mathrm{~km}$ (Pearson et al., 2003).

\subsection{Registros de xenólitos do manto no Brasil}

Meyer \& Svisero (1987) apresentaram uma compilação das ocorrências de xenólitos do manto até então conhecidos no continente sul-americano (Figura 4). 


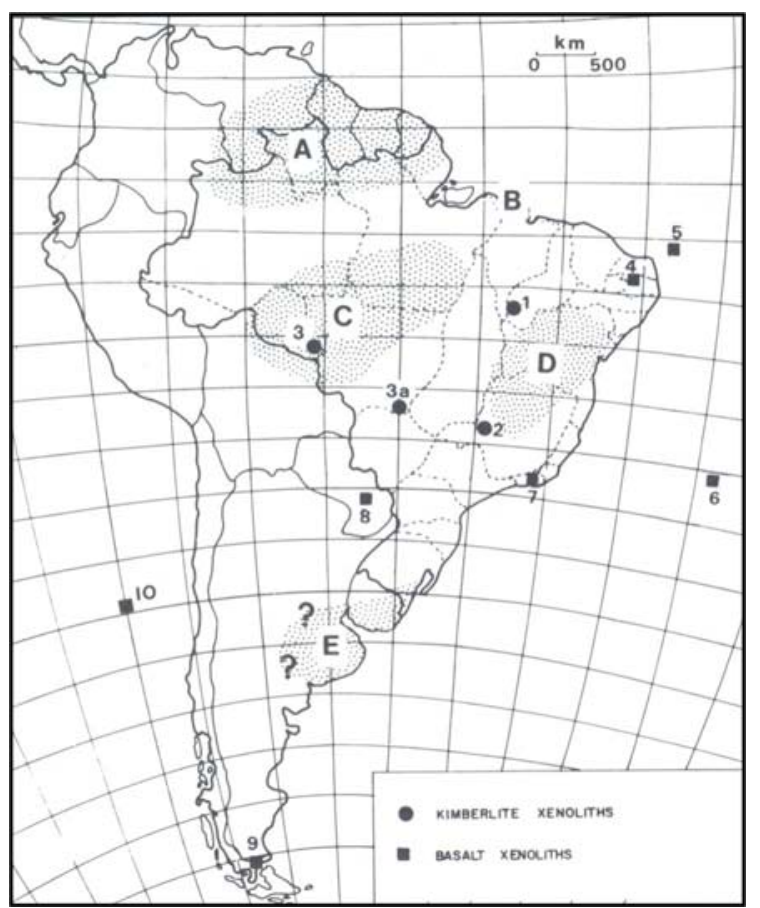

Figura 4: Localização de xenólitos mantélicos na América do Sul. 1: Redondão e Belmonte (Pi); 2: Coromandel (MG); 3: Concordo (RO); 3 a: Batovi (MT); 4: Paraíba e Rio Grande do Norte; 5: Ilha de São José; 6: Trindade; 7: Guaratiba; 8: Assunción; 9: Pali-Aike, Patagônia; 10: Iha Juan Fernandez. A: Craton da Guyana. B: Craton São Luiz. C: Craton Brasil Central. D: Craton São Francisco. E: Craton Rio de La Plata.

Círculos: xenólitos em kimberlitos. Quadrados: xenólitos em basaltos. Extraído de Meyer \& Svisero (1987).

Um expressivo número de trabalhos está relacionado às ocorrências de xenólitos do manto da região nordeste do país. Esses xenólitos são de fácies espinélio, têm dimensões variando de cerca de 1 a $35 \mathrm{~cm}$ e texturas protogranular e porfiroclástica (Rivalenti et al. 2000, Fodor et al. 2002). Encontram-se inclusos em basaltos alcalinos terciários, relacionados com a pluma de Fernando de Noronha, presentes nos estados do Rio Grande do Norte e Pernambuco, incluindo Fernando de Noronha. Xenólitos de peridotito em basaltos alcalinos no Rio Grande do Norte foram primeiro reportados por Sial (1977). Comin-Chiaramonti et al. (1986), Sial (1991), Princivalle et al. (1994), Rivalenti et al. (2000) e Fodor et al. (2002) prosseguiram com o estudo desses xenólitos. Comin-Chiaramonti et al. (1986) notaram uma heterogeneidade regional ao comparar xenólitos provenientes do Rio Grande do Norte e do Paraguai, mostrando que as amostras mais ricas em elementos incompatíveis são provenientes desta última região. Xenólitos de Fernando de Noronha foram primeiro referidos por Almeida (1958). Trabalhos posteriores focados nesses xenólitos incluem os de Rivalenti et al. (2000) e Kogarko et al. (2001).

O primeiro xenólito mantélico com granada do Brasil foi encontrado no Kimberlito Redondão no estado do Piauí por Svisero et al. (1977). Este também foi o primeiro kimberlito descoberto no país e apresenta xenólitos da crosta inferior e amostras de granada lherzolito. $O$ kimberlito Belmonte ocorre nessa mesma região e também exibe xenólitos de granada Iherzolito (Meyer \& Svisero, 1987). No estado da Bahia, porção norte do cráton do São Francisco, Donatti Filho (2008) descreve macrocristais de olivina e flogopita e granada de derivação eclogítica, harzburgítica e Iherzolítica incluídos em rochas kimberlíticas da Província kimberlítica diamantífera de Braúna, de idade proterozóica (682 $\pm 20 \mathrm{Ma}$, K-Ar, Pisani et al. 2001). 
Na região centro-oeste do Brasil, xenólitos mantélicos foram identificados na Província do Paranatinga (idades de 122,6-126,3 Ma, U-Pb, Heaman et al., 1998), situada na borda sul do Cráton Amazônico, Estado do Mato Grosso, onde ocorrem corpos kimberlíticos como o Batovi 6, com xenólitos de granada Iherzolito (Weska \& Svisero, 2001). A Província kimberlítica de Juína ou Aripuanã (91,6-94,6 Ma, U-Pb, Heaman et al., 1998), também localizada na parte meridional do Cráton Amazônico no Mato Grosso, apresenta intrusões com xenólitos de granada peridotitos, granada \pm espinélio peridotitos, eclogitos biminerálicos e coesita-sanidina eclogitos (Costa \& Gaspar, 2001). Ainda ocorrem megacristais de granada, ilmenita, clinopiroxênio, flogopita e espinélio, além de raros nódulos com mica e anfibólio e nódulo com intercrescimento gráfico de ilmenita e clinopiroxênio. Este último, encontrado principalmente em kimberlitos, representa amostra cristalizada em grandes profundidades no manto (Costa \& Gaspar, 2001). Xenólitos de espinélio Iherzolitos presentes em kamafugitos também são descritos na Província Alcalina de Goiás (Carlson et al., 2007).

Nas regiões de Coromandel e Monte Carmelo (SW de Minas Gerais), inseridas na Província Alcalina do Alto do Paranaíba, a ocorrência de xenólitos do manto é reportada com freqüência, como constituintes de corpos intrusivos kimberlíticos, kamafugíticos e afins (Meyer \& Svisero, 1991; Leonardos et al. 1993; Carlson et al. 2007; Costa, 1996; Carvalho, 1997). O kimberlito Três Ranchos é um exemplo cujos xenólitos de granada Iherzolito apresentam registros de pressão e temperatura relativas ao campo de estabilidade do diamante (Leonardos et al.,1993). Segundo Carlson et al. (2007) os xenólitos de Coromandel representam restitos antigos de fusão parcial ocorrida no Arqueano a Paleoproterozóico com metassomatismo no Ciclo Brasiliano (tardi-Neoproterozóico). A região de Córrego da Cachoeira (MG), na borda sul do cráton São Francisco, também mostra ocorrências de xenólitos de peridotitos com granada e espinélio e eclogitos inclusos no kimberlito mineralizado Canastra 1 (Costa et al., 2008).

Xenólitos de espinélio Iherzolito foram identificados no litoral do Estado do Rio de Janeiro, associado a blocos soltos em costão na região de Guaratiba, cerca de $40 \mathrm{~km}$ a oeste da cidade do Rio de Janeiro e estudados preliminarmente por Helmbold (1968). Há também referências a xenólitos de espinélio Iherzolito em dique no maciço de Itatiaia (Riccomini et al., 2005). 


\section{XENÓLITOS DO LAMPRÓFIRO DA PRAIA VERMELHA (UBATUBA - SP)}

\subsection{Situação geológica}

O lamprófiro da Praia Vermelha é parte de um enxame de diques de orientação típica ENE aflorante no litoral norte do Estado de São Paulo e integrante da Província Ígnea da Serra do Mar (Thompson et al., 1998) (Figura 5) com ocorrências magmáticas (intrusões alcalinas e enxames de diques) que intrudem o embasamento cristalino de terrenos metamórficos proterozóicos da Faixa de Dobramentos Ribeira (Brotzu et al., 2005).

Os diques e as intrusões estão estruturalmente relacionadas com um sistema de falhas de direção ENE-EW desenvolvidos no Ciclo Brasiliano e reativados no Cretáceo por movimentos extensionais relacionados com a abertura do Atlântico e/ou por um soerguimento regional relacionado com a trilha da pluma de Trindade (Thompson et al., 1998).

As intrusões alcalinas maiores (Itatiaia, Passa Quatro, Ilha de São Sebastião, Tinguá, Tanguá, Soarinho, Rio Bonito, Mendanha) são encontradas do maciço de Poços de Caldas até Cabo Frio e Morro de São João (Figura 5) (Brotzu et al., 2005). Uma característica comum dos complexos intrusivos é a presença dominante de alkali sienitos e nefelina sienitos, sendo que alguns dos complexos (e.g. Itatiaia, Soarinho) mostram também afloramentos de sienitos com quartzo e granitos.

Descrições detalhadas sobre os diques podem ser encontradas em Garda (1995), Garda et al. (1995) e Brotzu et al. (2005). Segundo Garda (1995), os litotipos principais dos diques costeiros entre as cidades de São Sebastião e Ubatuba variam de básicos a intermediários, com ocorrências de lamprófiros alcalinos. As rochas dos diques alcalinos integram uma suíte mais insaturada em sílica (foiditos/basanitos e rochas fonolíticas) e uma suíte pouco insaturada em sílica (basaltos alcalinos, traquibasaltos, hawaiitos, traquiandesitos e traquitos) (Brotzu et al., 2005). Os lamprófiros, suíte mais insaturada, têm composição variada, mas parecem, em sua maior parte, associados temporal e geneticamente ao magmatismo de idade Cretácea ( $85 \mathrm{Ma}$ ) que gerou os corpos alcalinos expressivos como as intrusões São Sebastião, Serraria e Mirante na llha de São Sebastião (Bellieni et al., 1990), além das ilhas de Búzios, Montão de Trigo e Vitória, entre outras (Rojas et al., 2005). As ocorrências básicas a intermediárias parecem estar relacionadas com o magmatismo da Bacia do Paraná (130 Ma) (Garda, 1995). 


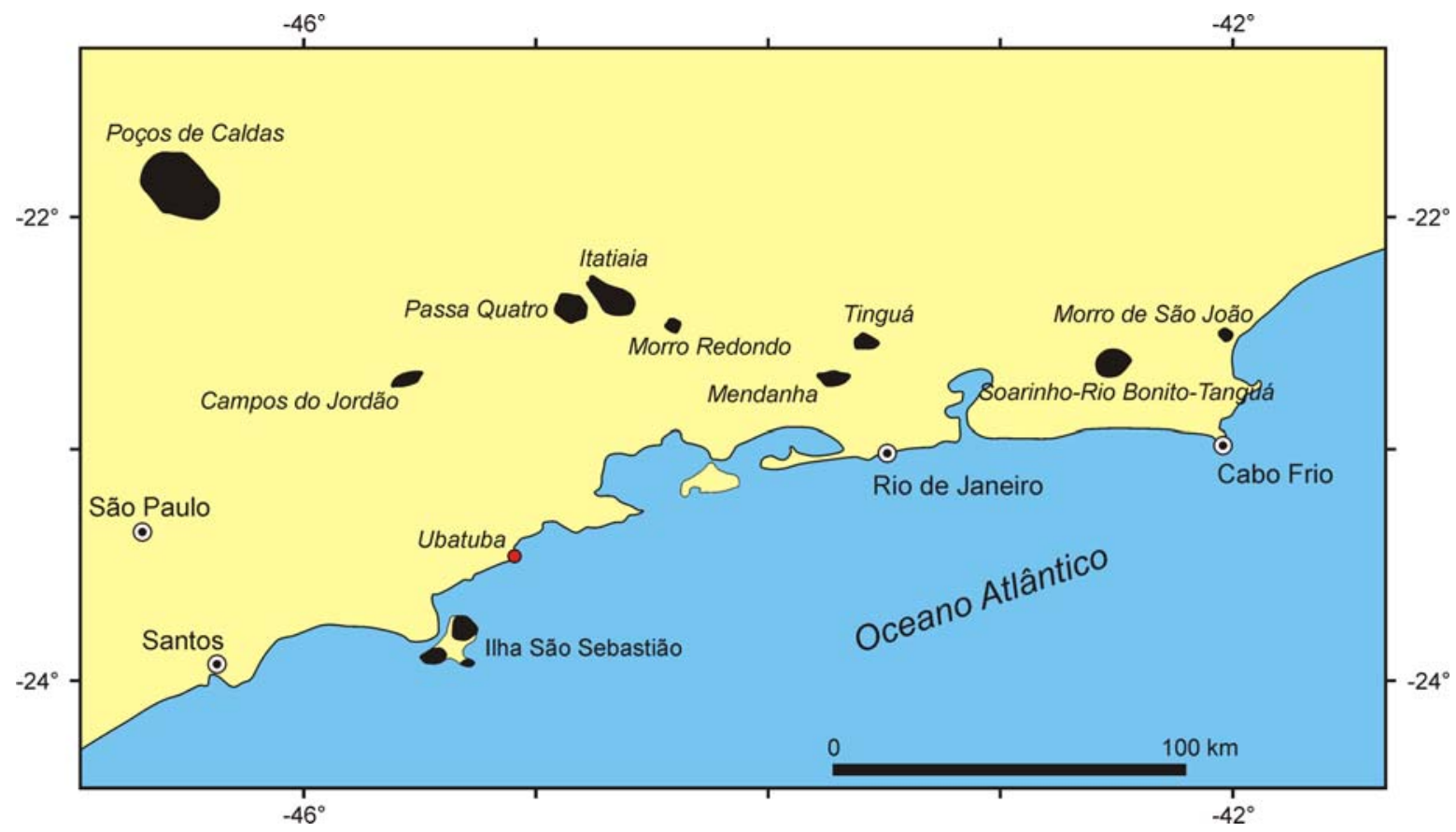

Figura 5: Mapa com a localização do dique de lamprófiro na Praia Vermelha de Ubatuba (SP) (ponto em vermelho) e sua relação geográfica com as principais intrusões alcalinas de idade mesozóica. Modificado de Brotzu et al. (2005).

O dique subvertical da Praia Vermelha que hospeda os xenólitos (Figuras 6a e 6b), tem espessura da ordem de 1,5 m, e é constituído por um kaersutita lamprófiro de coloração cinzaescura, que mostra significativo zoneamento entre a borda afanítica e o centro, normalmente de granulação fina a média. Em dois locais, no entanto, ocorrem no núcleo do dique zonas de contorno elipsoidal (Figura 6c) constituídas, em planta, por uma brecha com clastos de granito gnáissico (rocha encaixante) e localmente vidro vulcânico, sustentados por matriz de rocha vítrea esferulítica, interpretadas como brechas de conduto vulcânico (Garda et al., 1995).

Os xenólitos, todos com composição de espinélio peridotitos, foram identificados em trabalhos de campo da disciplina de graduação Petrologia ígnea, e reportados em Janasi et al. (2006). Ao microscópio petrográfico o lamprófiro apresenta feno/xenocristais de olivina imersos em matriz (Figura 7) composta por piroxênio amarronzado (Ti-augitas), kaersutita, olivina, biotita, feldspatóides e minerais opacos. 


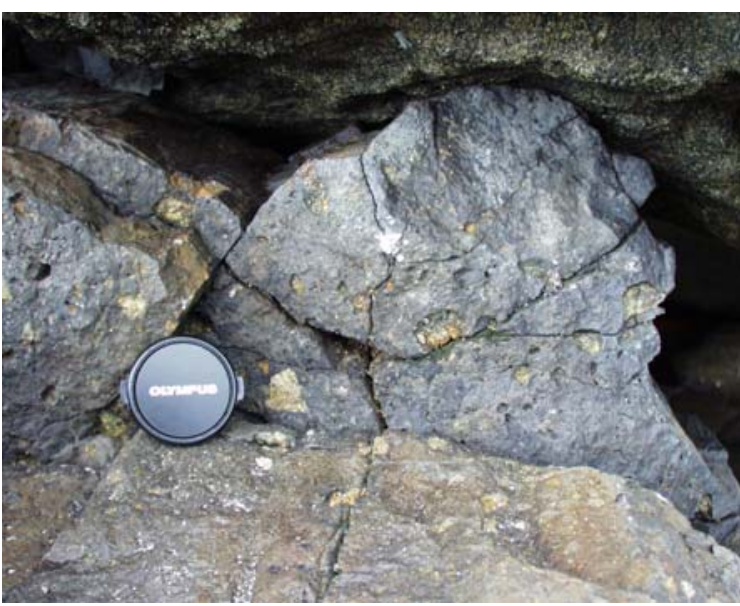

(a)

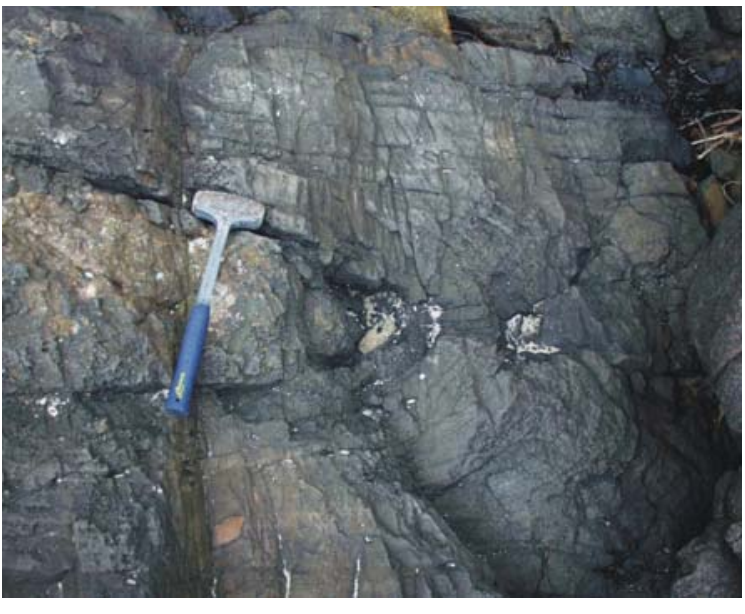

(c)

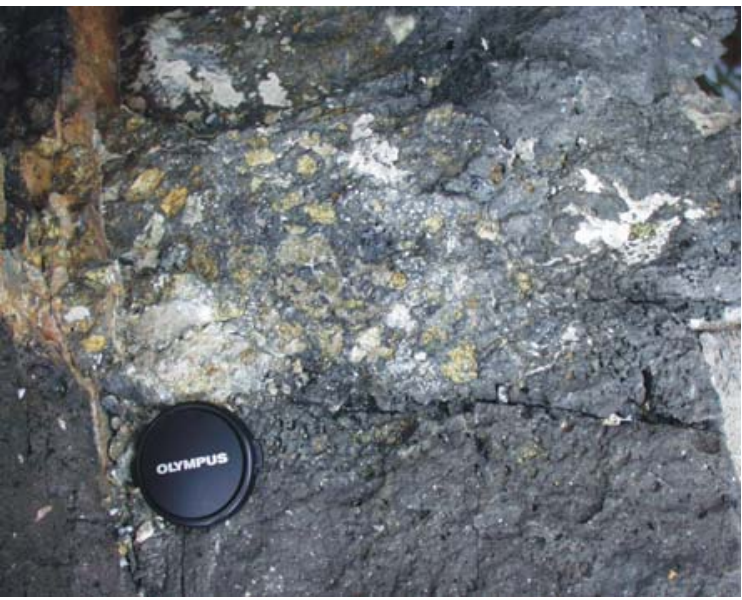

(b)

Figura 6: Dique de lamprófiro da Praia Vermelha (Ubatuba). (a) e (b) xenólitos mantélicos com alteração marrom esverdeada, (c) Região do dique com contorno elipsoidal.

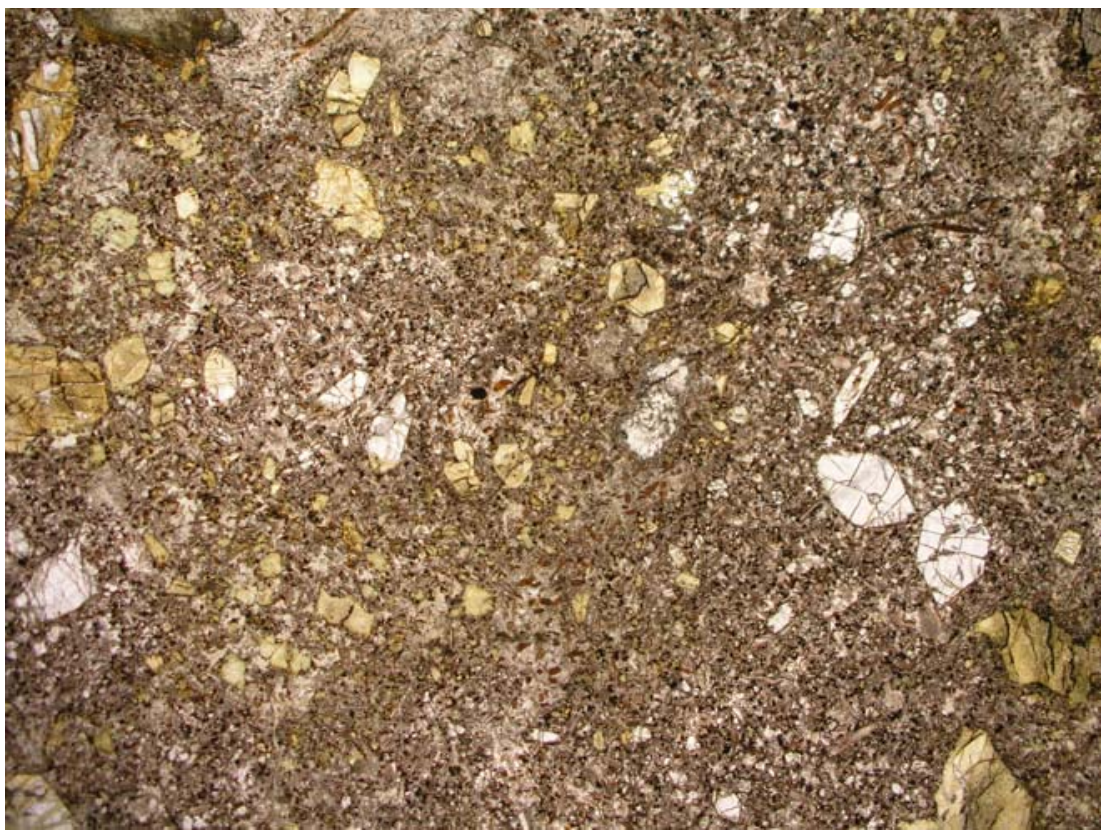

Figura 7: Seção delgada do lamprófiro encaixante mostrando feno/xenocristais de olivina euédrica a subédrica em matriz fina. Lado maior da foto: 10,4 mm. 


\subsection{Petrografia}

O estudo petrográfico foi focado nos xenólitos maiores. No total foram descritos em detalhe 5 xenólitos com dimensão de até $2 \mathrm{~cm}$ com cores verde e amarelo-esverdeado. A granulação é média a grossa. Os xenólitos maiores possuem forma subarredondada, por vezes assemelhada à de gotas (xenólito Ln9xm3).

A textura geral é protogranular, onde os cristais são delimitados por contatos curvados e retos. Foram realizadas estimativas modais por contagem de pontos de dois xenólitos (Ln9xm1 e Ln9xm3). Os resultados encontram-se na Tabela 3, juntamente com as estimativas visuais dos outros xenólitos. O diagrama de Streckeisen (1976), com classificação dos xenólitos, encontra-se na Figura 8. Todos os xenólitos correspondem a peridotitos. Os xenólitos Ln9xm1 e Ln9xm3, submetidos à contagem de pontos, foram classificados como espinélio Iherzolitos, mas apresentaram diferenças significativas quanto à proporção modal dos minerais. O xenólito Ln9xm2 foi o único classificado como wehrlito, no entanto, a estimativa foi feita em uma lâmina que representa um fragmento de um xenólito maior cuja composição global não foi estimada.

Alguns autores utilizam a química mineral como um auxílio na classificação de xenólitos pequenos, já que a proporção modal, nesses casos, não é considerada representativa. Fodor et al. (2002), por exemplo, classificaram xenólitos do Rio Grande do Norte pelo $\mathrm{Cr} \#(\mathrm{Cr} /(\mathrm{Cr}+\mathrm{Al}))$ dos cristais de espinélio, com base em trabalhos como os de Fan \& Hooper (1989) e Batanova \& Sobolev (2000), onde espinélios com Cr\# maior que 30 definem o campo de harzburgitos com clinopiroxênio (clinopyroxene-bearing harzburgite) e Cr\# menor que 30 o campo de Iherzolitos. Essa classificação será discutida com mais detalhe no capítulo da química mineral.

Tabela 3: Caracterização geral dos xenólitos maiores de Ubatuba.

\begin{tabular}{lllcccccc}
\hline Xenólito & Dimensão & Textura & Ol & Opx & Cpx & Sp & Ops & Classificação \\
\hline Ln9xm1* & $1 \mathrm{~cm}$ & Protogranular & 81,8 & 6,7 & 10,7 & 0,6 & 0,2 & sp-lherzolito \\
Ln9xm2 & $2 \mathrm{~cm}$ & Protog. c/ simplectito & 72 & 3 & 25 & - & - & wehrlito \\
Ln9xm3* & $2 \mathrm{~cm}$ & Protogranular & 49,4 & 34,7 & 11,8 & 3,5 & 0,6 & sp-Iherzolito \\
Ln9h & $1 \mathrm{~cm}$ & Protogranular & 66 & 10 & 15 & 8 & 1 & sp-lherzolito \\
Ln9g & $7 \mathrm{~mm}$ & Protogranular & - & - & - & - & - & não classificado \\
\hline
\end{tabular}

*estimativa por contagem de pontos. 


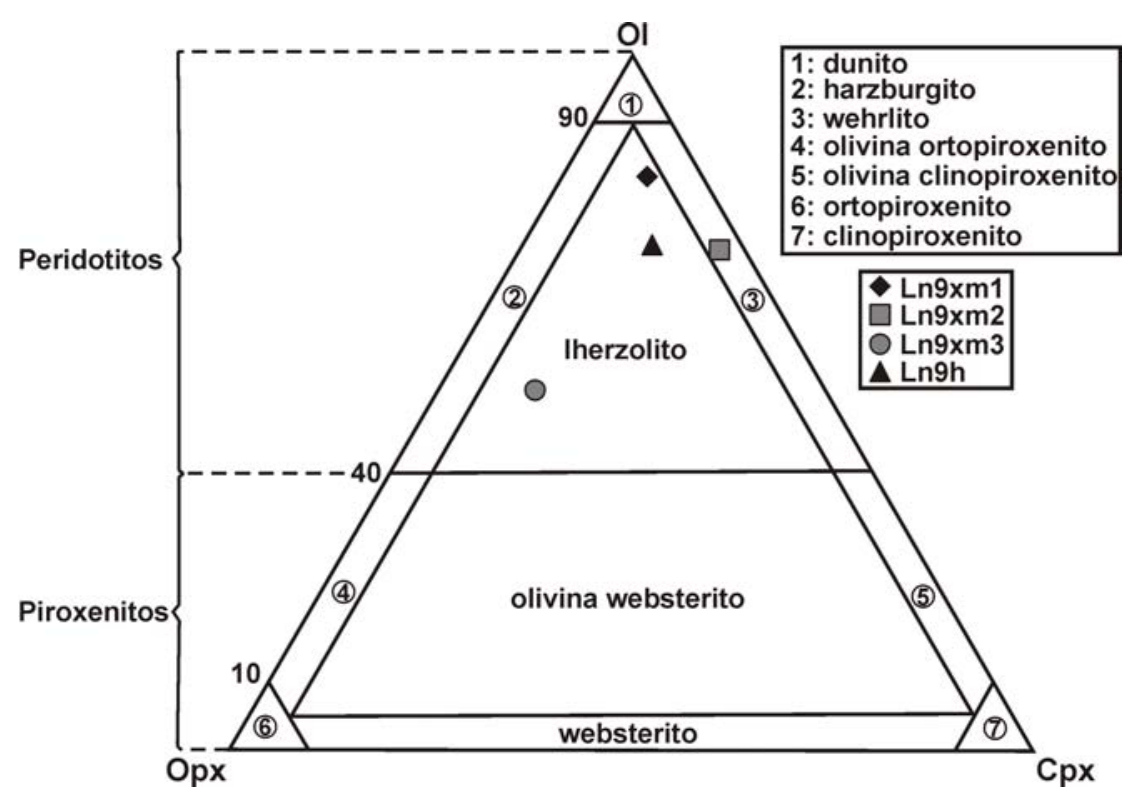

Figura 8: Diagrama de Streckeisen (1976) com classificação dos xenólitos maiores de Ubatuba.

Os xenólitos foram separados petrograficamente nos grupos 1 (espinélio Iherzolitos), 2 (wehrlitos) e 3 (fragmentos menores) de acordo com a proporção modal dos minerais essenciais de espinélio peridotitos e da textura. Xenólitos com características semelhantes foram descritos em um mesmo item da petrografia. Foi feita mais de uma seção delgada de alguns xenólitos e todas as seções foram consideradas na descrição.

\subsubsection{Grupo 1: Espinélio Iherzolitos com textura protogranular}

\section{Xenólito Ln9xm1}

Esse xenólito apresenta dimensão de $1 \times 1 \mathrm{~cm}$. A textura geral é protogranular. A fotomicrografia encontra-se na Figura 9.

A olivina apresenta-se como cristais anédricos com 1 a $4 \mathrm{~mm}$ e está em contato curvado com cristais anédricos de ortopiroxênio com 0,7 a 1,5 mm. Sua extinção nem sempre é reta. Os cristais menores de ortopiroxênio estão incluídos em olivina. Cristais de clinopiroxênio são esverdeados, anédricos e com dimensões variando de 0,5 a $2 \mathrm{~mm}$ (Figura 10). Assim como em outros xenólitos, apresentam concentração de inclusões fluidas. Contatos levemente irregulares são observados entre clinopiroxênio e olivina e entre clinopiroxênio e ortopiroxênio. Apenas um cristal de espinélio ocorre na lâmina e está localizado próximo ao contato entre o xenólito e o lamprófiro hospedeiro. O cristal apresenta $2 \mathrm{~mm}$, cor marrom escuro e borda de cor preta. 


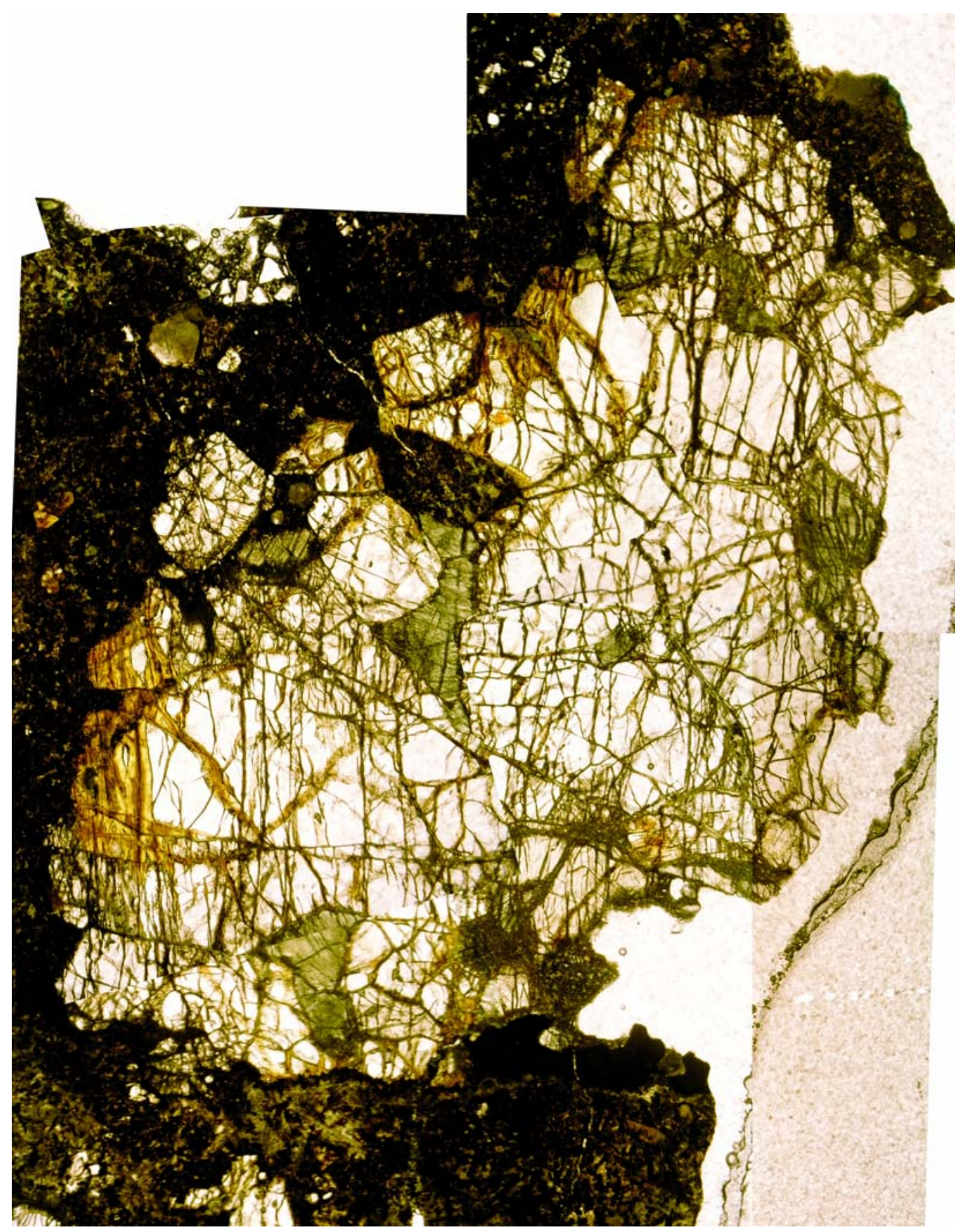

Figura 9: Fotomontagem da lâmina do xenólito Ln9xm1 a partir de fotomicrografias obtidas com a objetiva de 1,25x. Lado maior da montagem: 1,3 mm. Lado menor da montagem: 1,1 $\mathrm{mm}$. Lâmina com espessura de $60 \mu \mathrm{m}$. 


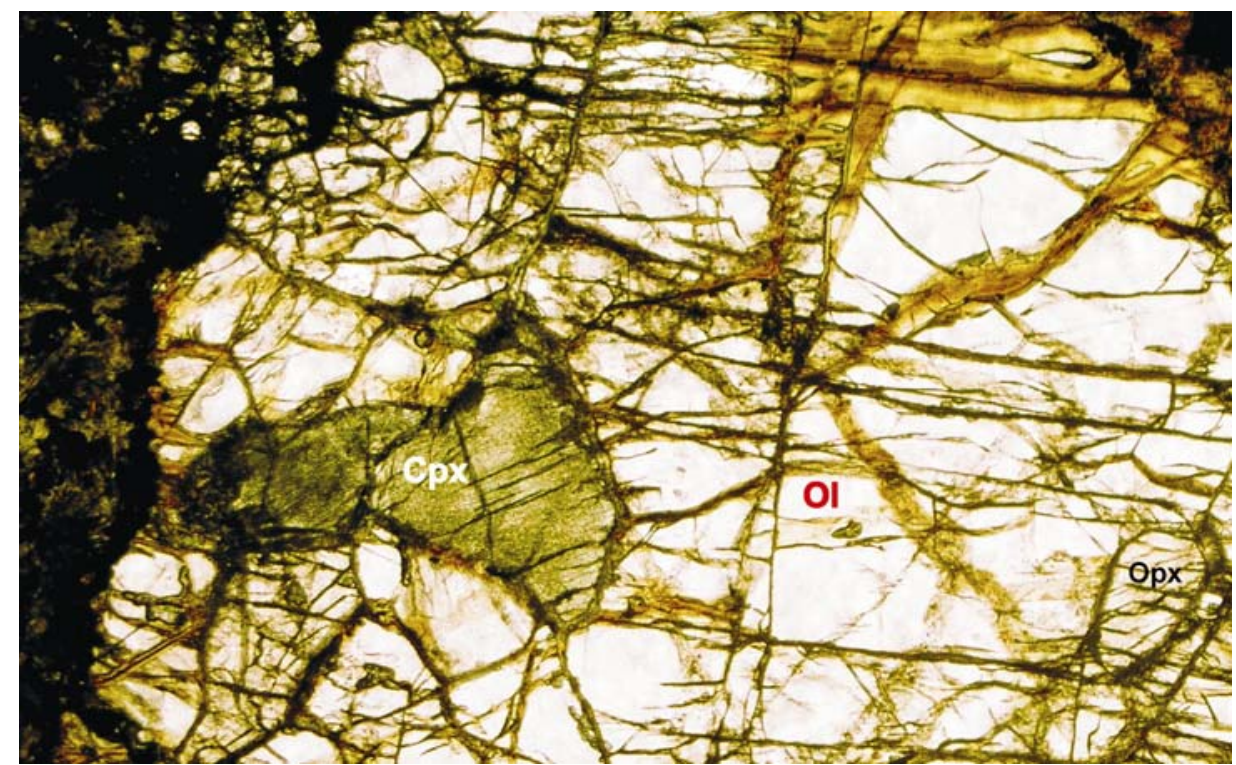

Figura 10: Cristal de clinopiroxênio (Cpx) esverdeado em contato com olivina (Ol). Ortopiroxênio (Opx) incluso em olivina (Ol) também é mostrado. Lâmina do xenólito Ln9xm1 com espessura de $60 \mu \mathrm{m}$. Polarizadores paralelos. Lado maior da foto: $4 \mathrm{~mm}$.

\section{Xenólitos Ln9xm3 e Ln9h}

Os xenólitos Ln9xm3 e Ln9h (Figuras 11 e 12) apresentaram maior proporção de cristais de espinélio.

No xenólito Ln9xm3 os contatos com o lamprófiro hospedeiro são curvados e limitados por uma borda de reação (Figura 13) com espessura variável entre 0,2 e 1,6 mm. A borda de reação apresenta pequenos cristais de minerais opacos na interface com o lamprófiro e pequenos cristais com 0,01 a $0,02 \mathrm{~mm}$ de clinopiroxênio com cor cinza esverdeado a marrom esverdeado na região interna, próxima ao xenólito.

A textura dos dois xenólitos é protogranular onde os cristais se limitam através de contatos curvados e até retos em algumas regiões.

A olivina do xenólito Ln9xm3 está presente na forma de pequenos cristais anédricos com 0,3 a 0,4 mm, geralmente substituída nas bordas ou totalmente alterada para material muito fino, fibroso, com cor amarelo amarronzado. Apresenta extinção levemente ondulante. Cristais de olivina por vezes estão inclusos total a parcialmente em cristais de ortopiroxênio. No xenólito Ln9h, a olivina pode apresentar maior dimensão (até $4,5 \mathrm{~mm}$ ), extinção levemente ondulante, e por vezes também é encontrada inclusa em ortopiroxênio anédrico com até $4 \mathrm{~mm}$. 


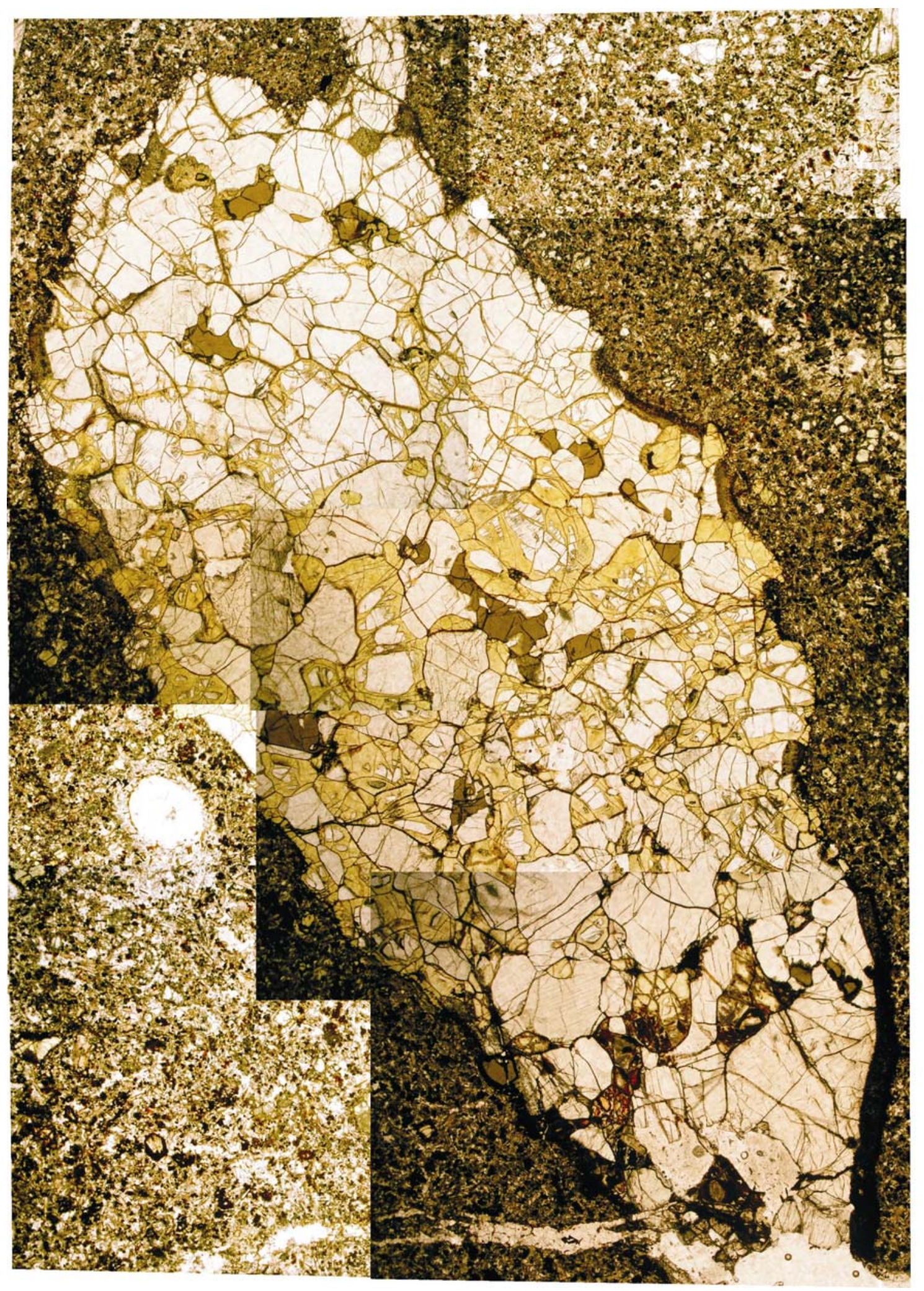

Figura 11: Fotomontagem da lâmina do xenólito Ln9xm3 a partir de fotomicrografias tiradas com objetiva de 1,25x. Lado maior da montagem: 2,2 cm. Lado menor da montagem: 1,4 cm. 


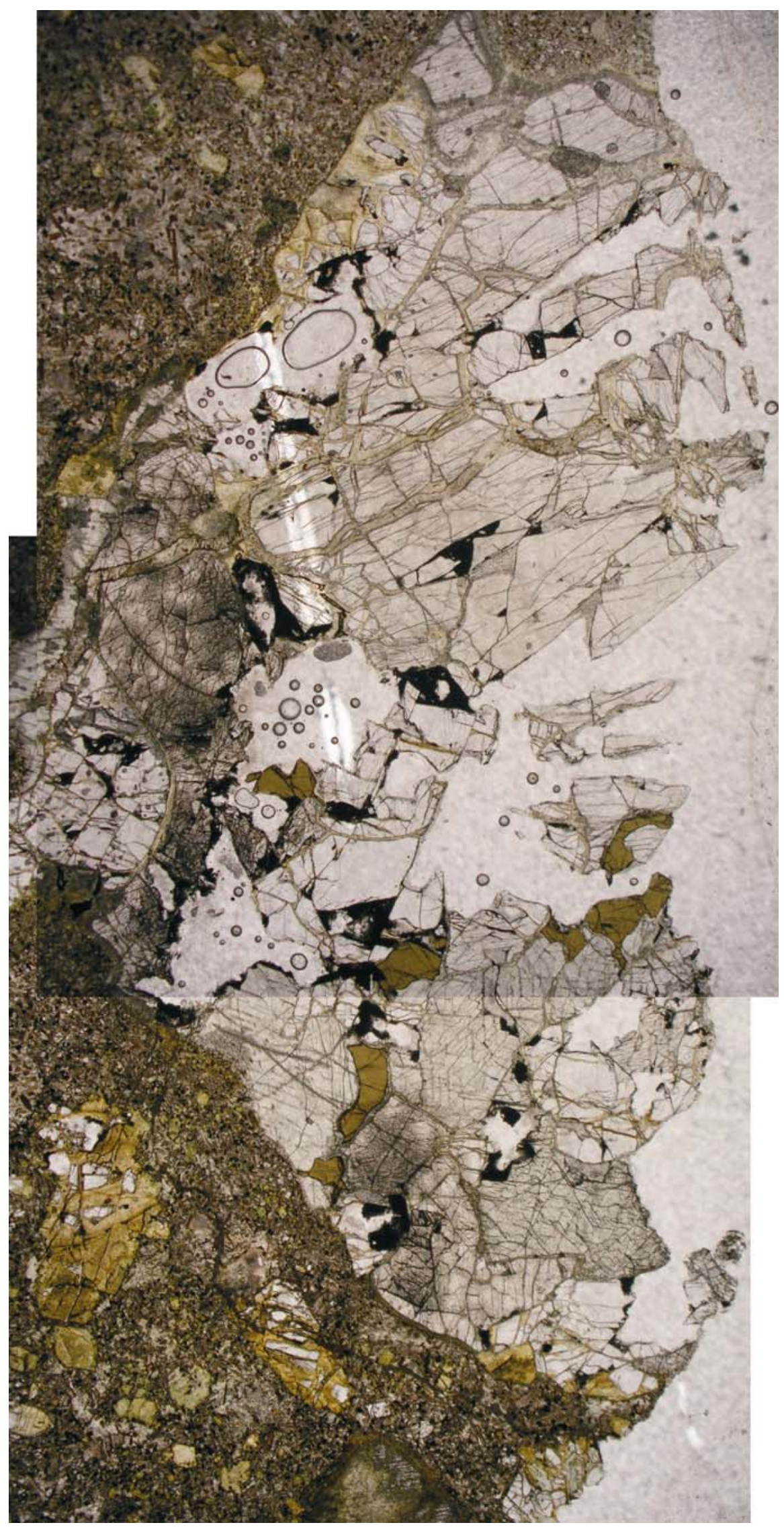

Figura 12: Fotomontagem da lâmina do xenólito Ln9h a partir de fotomicrografias tiradas com objetiva de 1,25x. Lado maior da montagem: 1,5 cm. Lado menor da montagem:1 cm. 


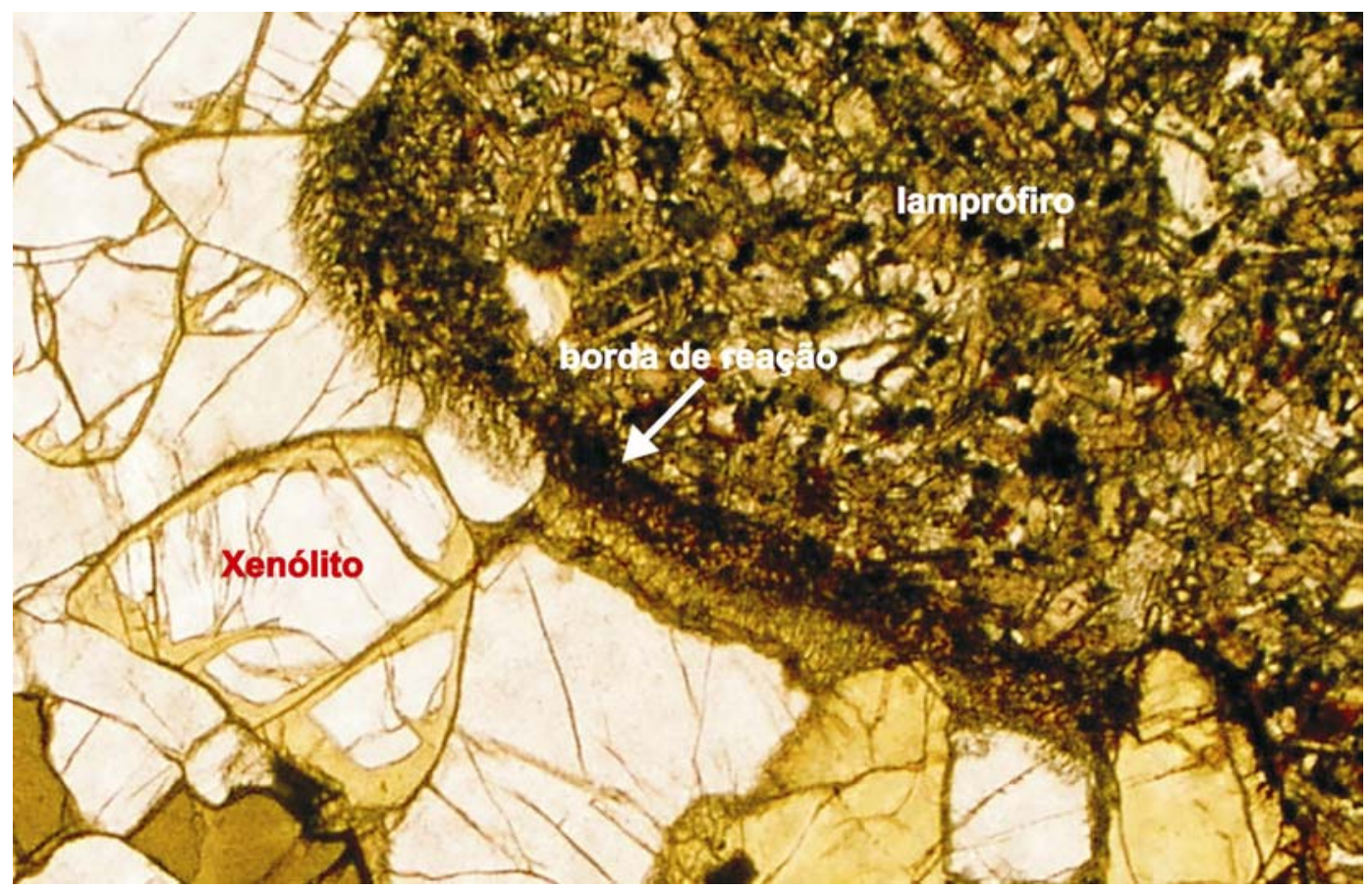

Figura 13: Borda de reação entre o xenólito Ln9xm3 e o lamprófiro encaixante. Polarizadores paralelos. Lado maior da foto: 2,6 $\mathrm{mm}$.

Os cristais de ortopiroxênio de Ln9xm3 também são anédricos e apresentam tonalidade cinza amarronzada. Apresentam tamanhos menores (1,5 a 3,1 mm) em relação aos de Ln9h e são mais fraturados em relação à olivina. Lamelas de exsolução muito finas concentradas próximo ao núcleo do cristal ocorrem em alguns casos (Figura 14). Os cristais de clinopiroxênio do xenólito Ln9xm3 apresentam 0,6 a 2,3 mm. Apresentam tons esverdeados e são no geral anédricos, com exceção de um cristal subédrico. Parecem intersticiais em algumas regiões. Lamelas de exsolução muito finas podem ser observadas (Figura 14). O contato do clinopiroxênio com os outros minerais é curvado ou mais raramente reto. Algumas trilhas de inclusões fluidas são observadas principalmente nos piroxênios. Os cristais de olivina apresentam inclusões fluidas em proporção bem menor.

No xenólito Ln9h os cristais de clinopiroxênio são anédricos, com dimensão máxima de $2 \mathrm{~mm}$. Alguns são intersticiais, e apresentam concentração de inclusões fluidas nas bordas e talvez de líquido magmático. Não é observado desequilíbrio desses cristais com o restante do xenólito.

Os cristais de espinélio dos dois xenólitos apresentam cor verde oliva. Maior dimensão é observada no xenólito Ln9xm3 (até $2 \mathrm{~mm}$ ). São anédricos, podendo estar presentes nos interstícios ou, no caso de Ln9xm3, inclusos em ortopiroxênio. Geralmente apresentam borda muito fina $(\sim 0,02 \mathrm{~mm})$ de cor preta. Um cristal do xenólito Ln9xm3 está presente próximo à borda de reação do xenólito. Nesse caso apresenta cor marrom esverdeada e borda preta mais espessa $(0,2 \mathrm{~mm})$. Cristais de espinélio de Ln9h por vezes envolvem parcialmente os cristais de clinopiroxênio deste xenólito. 
Alguns pequenos cristais $(0,2$ a $0,4 \mathrm{~mm})$ anédricos de sulfetos são observados em associação com a alteração de olivina. Venulação preenchida por carbonato corta o lamprófiro e parcialmente o xenólito Ln9xm3.

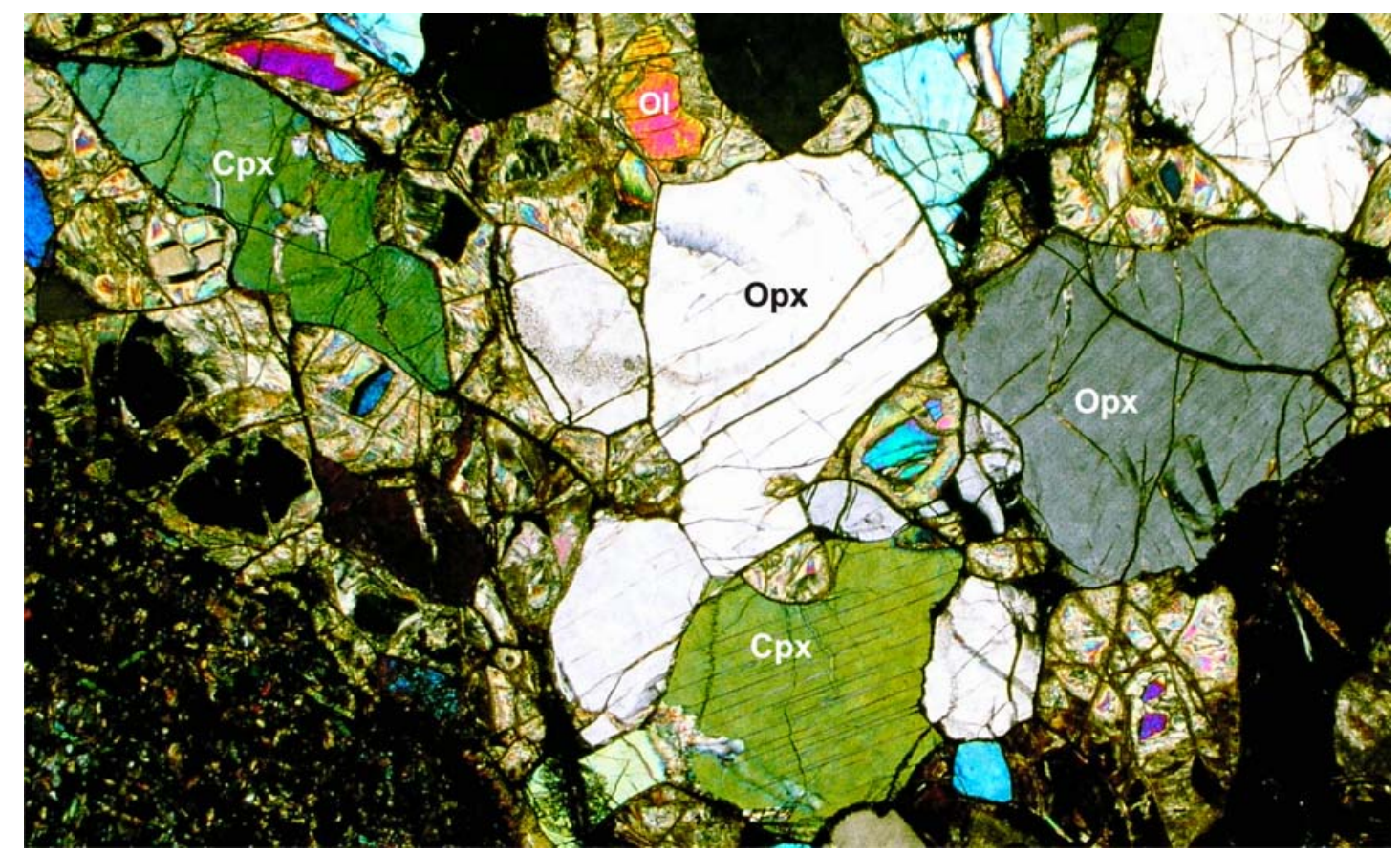

Figura 14: Cristais de ortopiroxênio (Opx), clinopiroxênio (Cpx) e olivina (Ol) associada a material de alteração do xenólito Ln9xm3. Notar as lamelas de exsolução nos cristais de piroxênio. Polarizadores cruzados. Lado maior da foto: $3 \mathrm{~mm}$.

\subsubsection{Grupo 2: Wehrlitos}

\section{Xenólito Ln9xm2}

A lâmina deste xenólito representa um fragmento de $2 \times 0,5 \mathrm{~cm}$ de um xenólito maior com contatos curvados com a rocha encaixante e cor amarela esverdeada.

O xenólito apresenta uma borda de reação com o lamprófiro com 1 a $2 \mathrm{~mm}$ de espessura (Figura 15). Essa borda de reação é composta por clinopiroxênio, cristais muito pequenos de até $0,15 \mathrm{~mm}$ de minerais opacos e cristais anédricos com cerca de $0,4 \mathrm{~mm}$ de olivina em continuidade óptica com cristal maior de olivina do xenólito. Cristais de kaersutita (do lamprófiro) também são encontrados nessa borda de reação e por vezes formam regiões circulares (estruturas globulares) com 0,3 a 0,8 mm. Os cristais de clinopiroxênio desta borda de reação são euédricos e apresentam 0,02 a $0,5 \mathrm{~mm}$. Os de maior dimensão são bastante alongados e formam conjuntos de cristais orientados segundo uma direção que se entrelaçam a um outro conjunto com diferente orientação. Cristais de carbonato com 0,03 mm também estão presentes. 


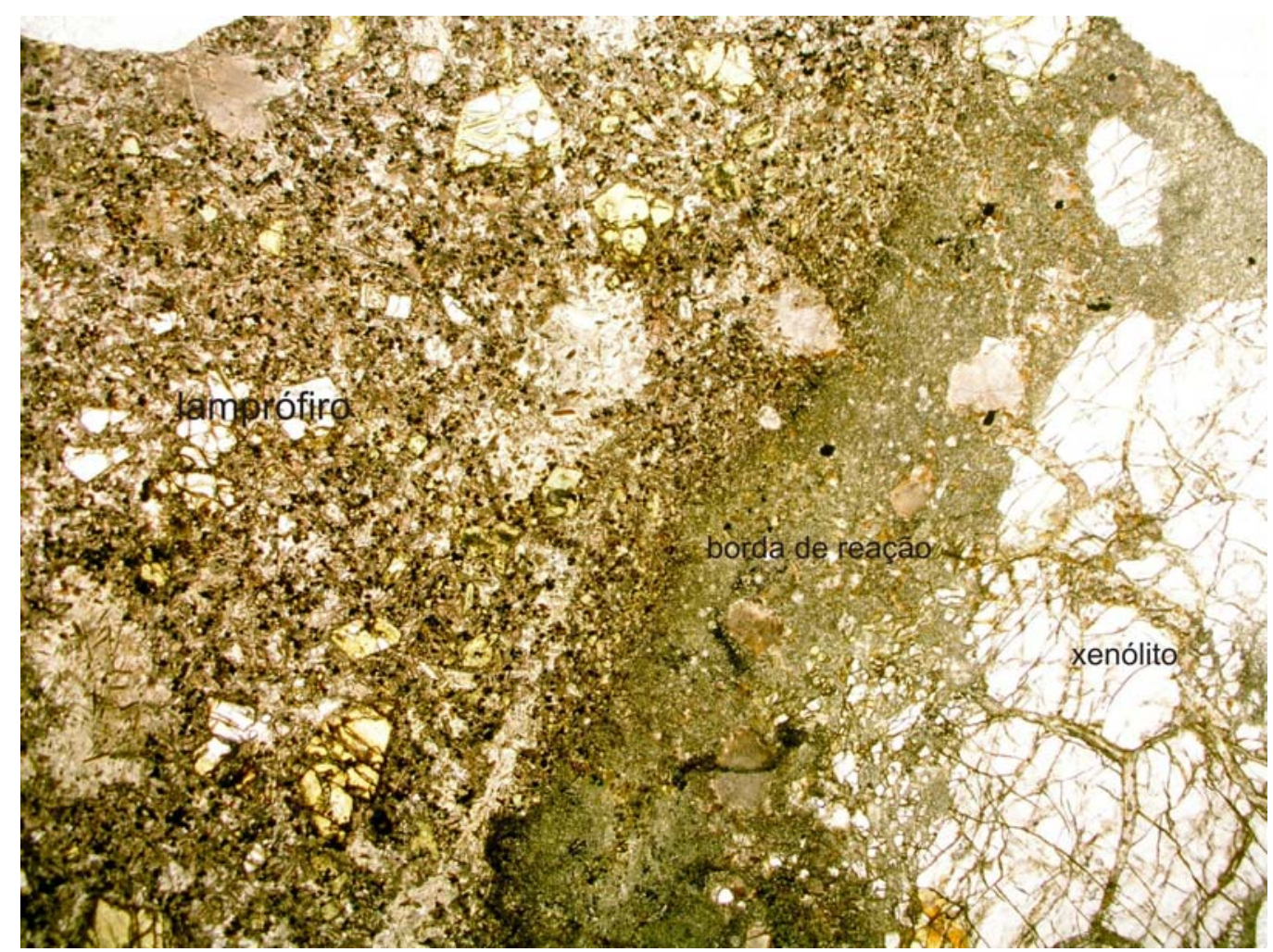

Figura 15: Borda de reação do xenólito Ln9xm2 com o lamprófiro. Polarizadores paralelos. Lado maior da foto: $10,4 \mathrm{~mm}$.

A parte mais interna do xenólito é composta por olivina, clinopiroxênio e ortopiroxênio em textura geral protogranular, com cristais em contatos curvados e retos em algumas regiões.

A olivina é representada por cristais pequenos, com 0,1 a 0,4 mm, anédricos, parcialmente substituídos, nas bordas e microfraturas, por serpentina. Esses cristais muito pequenos encontram-se associados com pequenos cristais euédricos de clinopiroxênio. Cristais maiores de olivina têm no máximo $4 \mathrm{~mm}$ e por vezes apresentam clivagem mais proeminente e trilhas de inclusões fluidas.

Cristais incolores e subédricos de clinopiroxênio com dimensão média de 1,8 mm encontram-se concentrados em uma região do xenólito intercrescidos com cristais menores e alongados de olivina com continuidade óptica que ocupam preferencialmente as suas clivagens (Figura 16). Alguns cristais alongados de olivina possuem orientação discordante da direção de clivagem. Contatos irregulares são observados entre esses cristais maiores de clinopiroxênio e os cristais maiores de olivina. 

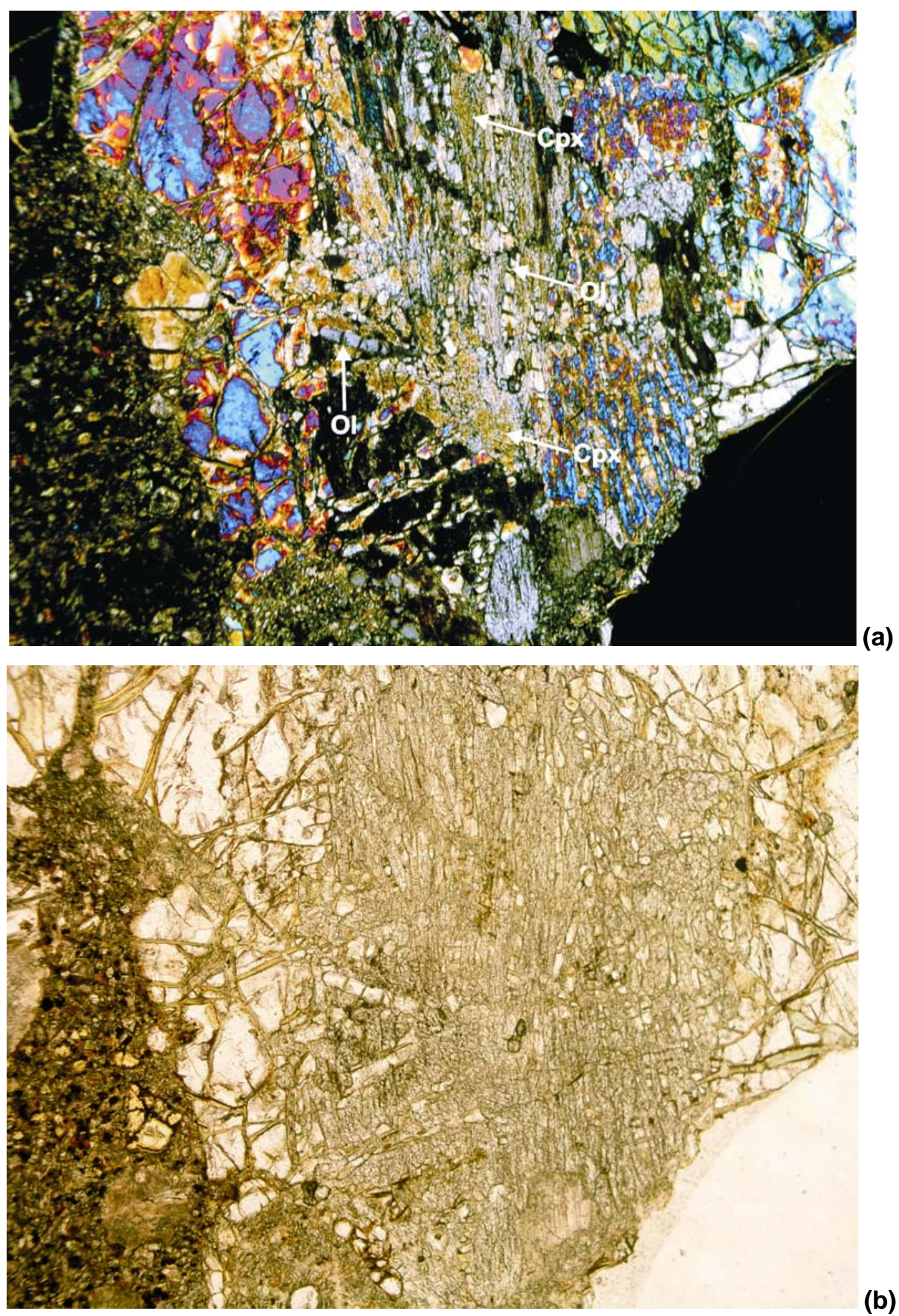

(a)

(b)

Figura 16: Intercrescimento de clinopiroxênio e olivina (centro da foto) no xenólito Ln9xm2. Polarizadores cruzados (a) e paralelos (b). Lado maior da foto: 3,25 mm.

O ortopiroxênio está presente na forma de pequenos cristais $(0,3 \mathrm{~mm})$ anédricos e subédricos em contato irregular com o clinopiroxênio.

Venulações com 0,1 a 0,2 mm de espessura cortam o xenólito e o lamprófiro. Esses veios apresentam cor cinza amarronzado e estão preenchidos por cristais muito pequenos de flogopita, minerais opacos e carbonato. 


\subsubsection{Grupo 3: Fragmentos menores}

\section{Xenólito Ln9g}

O xenólito Ln9g é o menor estudado, e tem dimensão maior de $7 \mathrm{~mm}$. A fotomicrografia encontra-se na Figura 17. Apresenta borda de reação com o lamprófiro composta por cristais muito finos de clinopiroxênio nas bordas do cristal de ortopiroxênio do xenólito. Uma segunda seção delgada deste mesmo xenólito mostrou borda de reação com cor rosada (clinopiroxênio) no mesmo cristal de ortopiroxênio (Figura 18). Este cristal representa quase a totalidade do xenólito É um cristal anédrico com cor cinza amarronzado e finas lamelas de exsolução. Apresenta inclusões de cristais anédricos de olivina e clinopiroxênio esverdeado, ambos em contato. Cristais maiores de olivina estão em contato curvado com o ortopiroxênio.

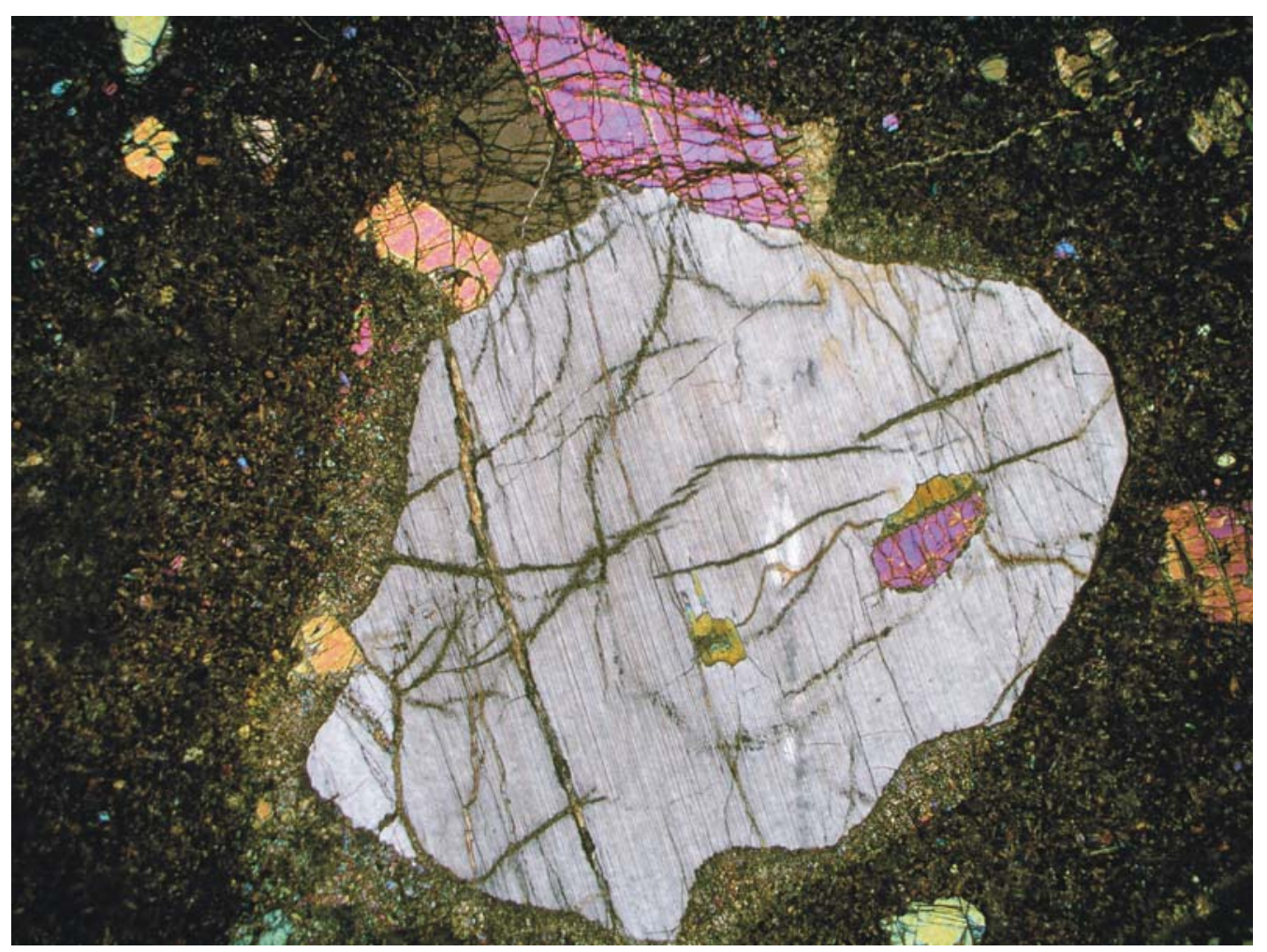

Figura 17: Visão geral do xenólito Ln9g com cristal de ortopiroxênio (centro da foto) com inclusão de olivina. Polarizadores cruzados. Lado maior da foto: 10,4 mm. 


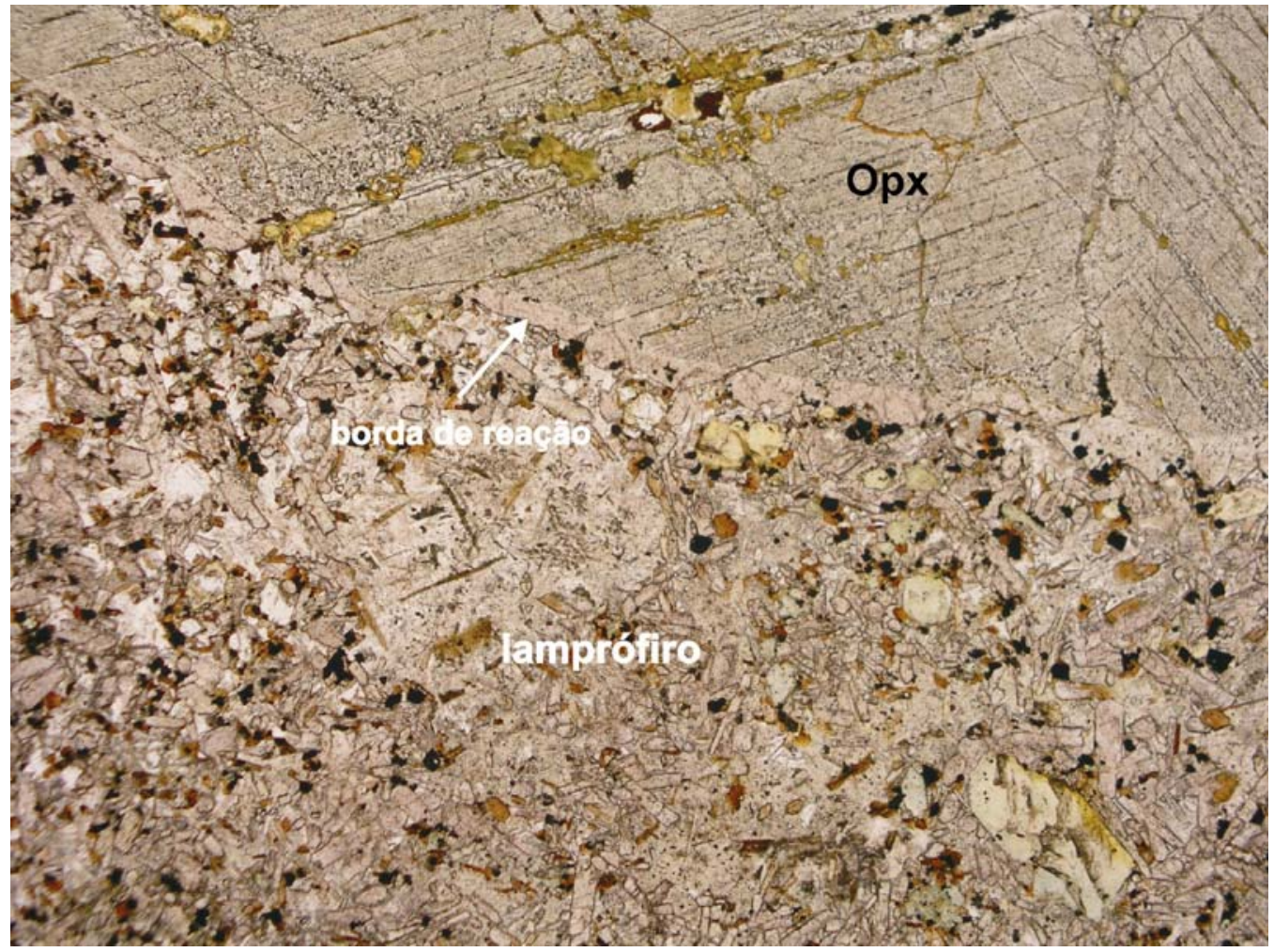

Figura 18: Borda de reação rosada em cristal de ortopiroxênio do xenólito $\mathrm{Ln9g}$ em contato com lamprófiro. Polarizadores paralelos. Lado maior da foto: 3,25 mm.

\subsubsection{Xenocristais/Fenocristais}

O lamprófiro hospedeiro também apresenta possíveis xenocristais dispersos na matriz que mostram evidências texturais de reação com a matriz. Os xenocristais observados são de olivina e ortopiroxênio e apresentam dimensão maior com cerca de 5 a $7 \mathrm{~mm}$. O ortopiroxênio pode apresentar lamelas de exsolução (Figura 19) como também observado em cristais dos xenólitos. Apesar de terem provável origem mantélica, não foram focados nesse estudo.

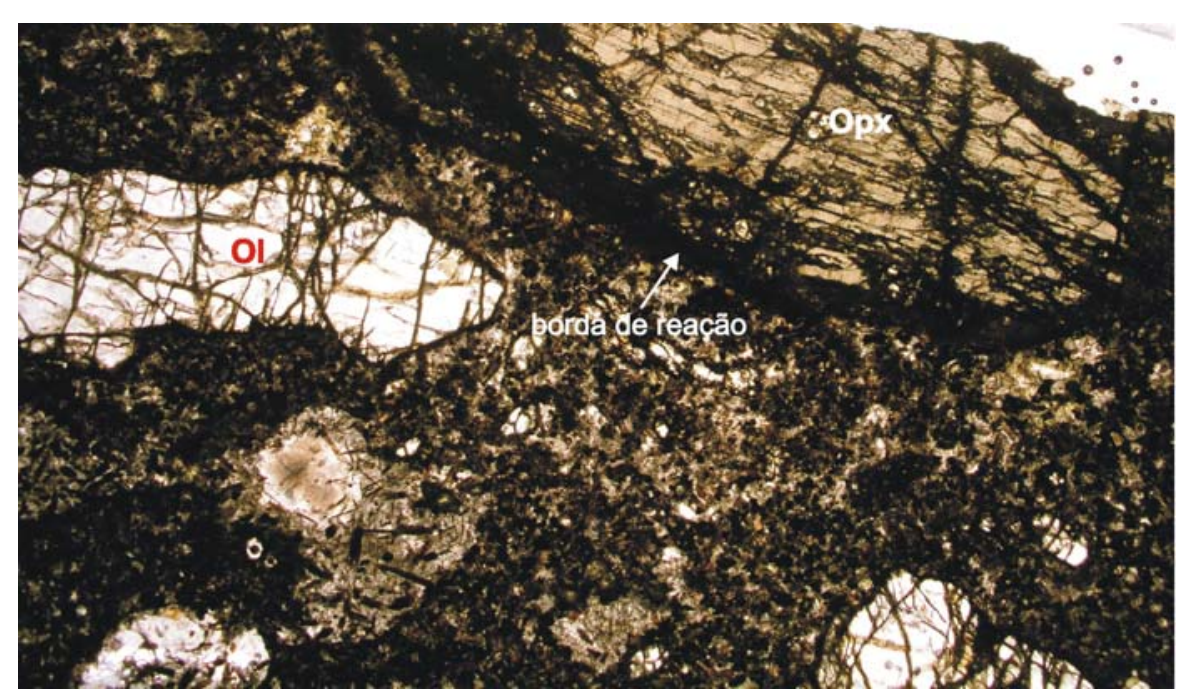

Figura 19: Xenocristais de ortopiroxênio (Opx) e olivina (OI) no lamprófiro. Polarizadores paralelos. Lâmina com espessura de $60 \mu \mathrm{m}$. Lado maior da foto: $10,4 \mathrm{~mm}$. 


\subsection{Química mineral}

Xenólitos dos grupos 1 (Ln9xm1, Ln9xm2 e Ln9h), 2 (Ln9xm2) e 3 (Ln9g) do lamprófiro da Praia Vermelha de Ubatuba foram analisados por microssonda eletrônica. Análises quantitativas por WDS foram feitas em cristais de olivina, piroxênio (ortopiroxênio e clinopiroxênio) e espinélio. Análises semiquantitativas por EDS foram feitas em sulfetos por microssonda eletrônica e microscópio eletrônico de varredura.

\subsubsection{Olivina}

Os resultados das análises de olivina dos xenólitos de Ubatuba encontram-se no Anexo 1. As composições variam de $\mathrm{Fo}_{88}$ a $\mathrm{Fo}_{91}$. Maiores teores em forsterita $\left(\mathrm{Fo}_{91}\right)$ foram encontrados em cristais dos xenólitos Ln9xm1 (grupo 1) e Ln9g (grupo 3). Esse último apresenta cristal com leve zoneamento próximo ao contato com o lamprófiro (borda $\mathrm{Fo}_{91}$ e núcleo $\mathrm{Fo}_{86}$ ). A olivina dos xenólitos Ln9h e Ln9xm3 (grupo 1) apresenta teores intermediários de $\mathrm{Fo}\left(\mathrm{Fo}_{89}\right.$ e $\left.\mathrm{Fo}_{90}\right)$ e a do xenólito $\mathrm{Ln} 9 \mathrm{xm} 2$ (grupo 2) os teores mais baixos $\left(\mathrm{Fo}_{88}\right.$ e $\mathrm{Fo}_{89}$ ), em todos os casos sem variação entre núcleo e borda. Teores de $\mathrm{NiO}$ variam de 0,2 a $0,4 \%$ e $\mathrm{Cr}_{2} \mathrm{O}_{3}$ apresenta máximo de 0,04\% no xenólito Ln9g.

\subsubsection{Ortopiroxênio}

Os resultados das análises de ortopiroxênio encontram-se no Anexo 2. O diagrama de Morimoto (1988) (Figura 20) mostra a classificação dos cristais de ortopiroxênio. Todas as análises se situam no campo da enstatita, com composição variando de $W_{0,5} \mathrm{En}_{89} \mathrm{Fs}_{10,5}$ a $\mathrm{Wo}_{2} \mathrm{En}_{89} \mathrm{Fs}_{9}$, sem variação significativa entre núcleo e borda. Os valores de $\mathrm{Mg \#}$ $(100 * \mathrm{Mg} /(\mathrm{Mg}+\mathrm{Fe}))$ dos núcleos dos cristais variam de 89,6 (Ln9xm3) a 91,2 (Ln9g).

O cristal com lamelas de exsolução do xenólito Ln9g apresentou teores de $\mathrm{CaO}$ variando de 0,5 a $1 \%$. Variações significativas são observadas principalmente nos teores de $\mathrm{Al}_{2} \mathrm{O}_{3}$ e $\mathrm{TiO}_{2}$ entre os xenólitos. O xenólito do grupo 2 ( $\mathrm{Ln9xm2)}$ apresentou cristais com os menores teores de $\mathrm{Al}_{2} \mathrm{O}_{3}$ (máximo 2,4\%) e valores não detectáveis de $\mathrm{TiO}_{2}$, enquanto $\mathrm{Ln} 9 \times \mathrm{xm} 3$ apresentou o maior teor de $\mathrm{Al}_{2} \mathrm{O}_{3}$ (máximo de 4,9\%) e $\mathrm{TiO}_{2}$ (máximo de 0,2\%). O gráfico $\mathrm{Al}_{2} \mathrm{O}_{3}$ $x \mathrm{TiO}_{2}$ (Figura 21a) mostra a correlação positiva entre esses óxidos. Leve correlação negativa é observada entre os valores de $\mathrm{Al}_{2} \mathrm{O}_{3}$ e $\mathrm{Mg \#} \mathrm{(Figura} \mathrm{21b),} \mathrm{à} \mathrm{exceção} \mathrm{da} \mathrm{análise} \mathrm{do} \mathrm{xenólito}$ Ln9xm2. Maiores teores de $\mathrm{Cr}_{2} \mathrm{O}_{3}$ são encontrados no ortopiroxênio de $\operatorname{Ln9g}(0,7 \%)$. O ortopiroxênio dos xenólitos Ln9h e Ln9xm3 do grupo 1 (mais ricos em espinélio) apresentam 
menores teores de $\mathrm{Cr}_{2} \mathrm{O}_{3}$ em relação aos encontrados em Ln9xm1 (0,2 a 0,3\% nos primeiros contra 0,3 a $0,4 \%$ no último).

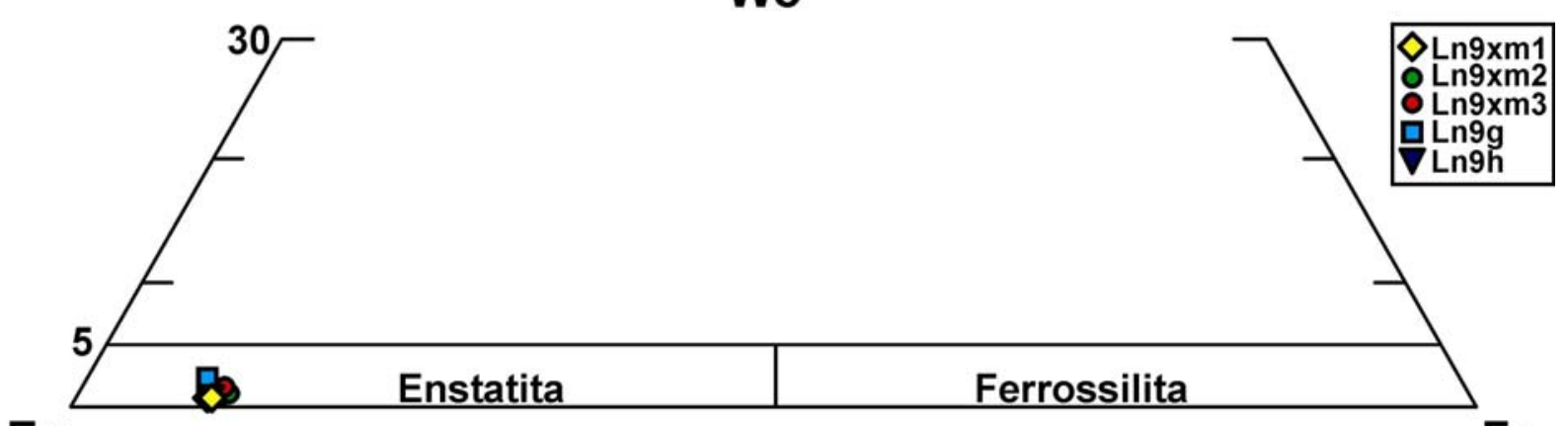

En

\section{Wo}

Figura 20: Diagrama de Morimoto (1988) com classificação dos cristais de ortopiroxênio analisados em xenólitos do manto de Ubatuba.

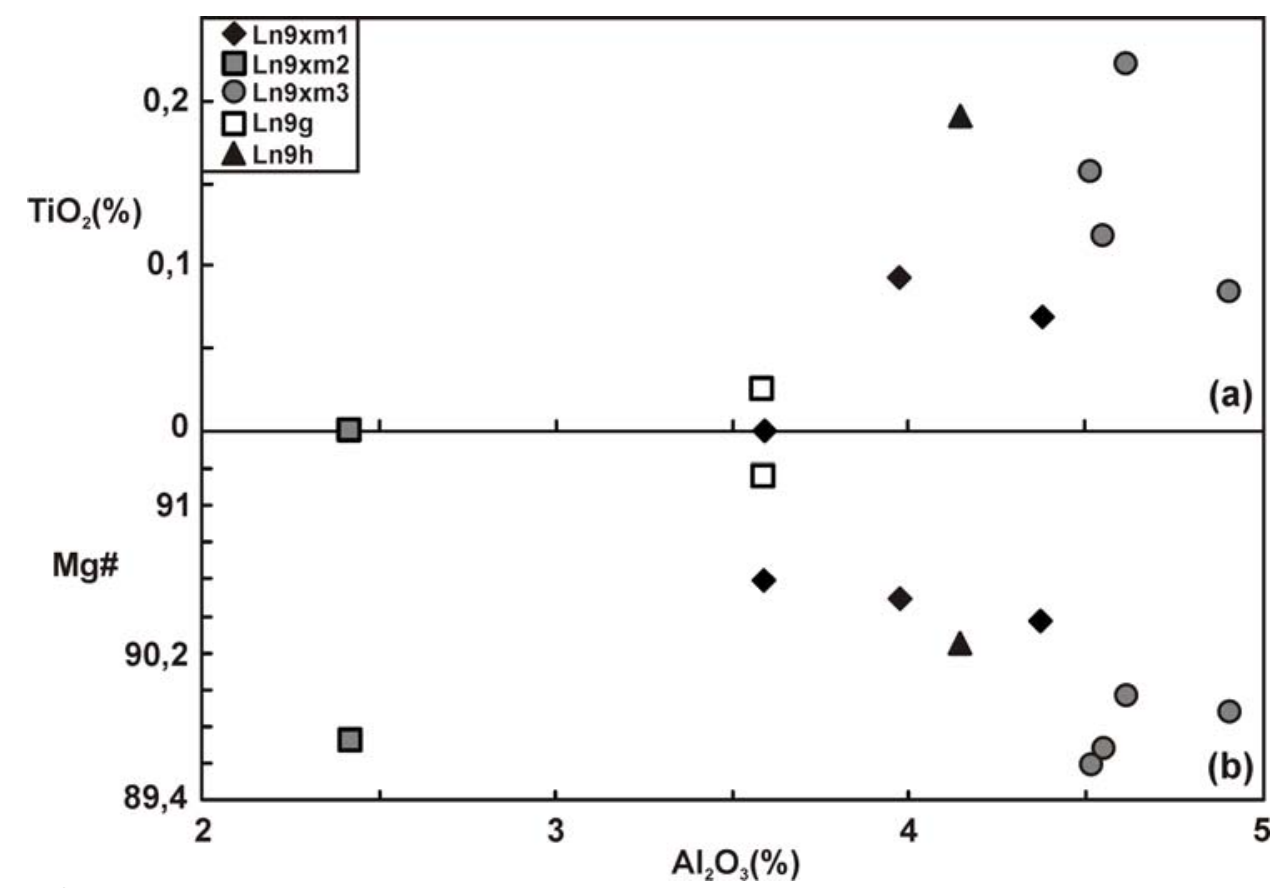

Figura 21: Composições de núcleos de cristais de ortopiroxênio de xenólitos do manto de Ubatuba mostrando a correlação positiva entre $\mathrm{Al}_{2} \mathrm{O}_{3}$ e $\mathrm{TiO}_{2}$ (a) e negativa entre $\mathrm{Al}_{2} \mathrm{O}_{3}$ e $\mathrm{Mg \#}$ (b) (exceção da análise do xenólito Ln9xm2).

\subsubsection{Clinopiroxênio}

Os resultados das análises de clinopiroxênio encontram-se no Anexo 3. As análises químicas de clinopiroxênio dos diferentes xenólitos foram representadas no quadrilátero (Quad) com a divisão de campos de Morimoto (1988) (Figura 22). Essa figura (diagrama WEF x Jd x 
Ae) também mostra diferença composicional do clinopiroxênio quanto à proporção de jadeíta $\left(\mathrm{NaAISi}_{2} \mathrm{O}_{6}\right)$, menor no xenólito Ln9xm2 (grupo 2) $\left(\mathrm{WEF}_{96} \mathrm{Jd}_{1} \mathrm{Ae}_{3}\right)$ e maior em Ln9h $\left(\mathrm{WEF}_{85} \mathrm{Jd}_{15} \mathrm{Ae}_{0}\right)$.

Os cristais podem ser classificados como diopsídio, à exceção de uma análise que se situa no limite dos campos da augita cálcica e do diopsídio $\left(\mathrm{Wo}_{44} \mathrm{En}_{50} \mathrm{Fs}_{6}\right.$, xenólito Ln9xm3, núcleo). Valores de $\mathrm{Mg \#} \mathrm{(Mg/(Mg+Fe)})$ de núcleos de cristais variam de 90,2 (Ln9xm3) a 91,6 (Ln9xm1).

Variações químicas significativas entre análises de núcleo e borda foram observadas em um cristal localizado no contato entre o xenólito Ln9xm3 e o lamprófiro. Nesse caso a borda é ligeiramente mais rica em $\mathrm{FeO}_{\mathrm{t}}$ e $\mathrm{CaO}$ em relação ao núcleo (respectivamente, $\mathrm{Wo}_{51} \mathrm{En}_{41} \mathrm{Fs}_{9}$ e $\mathrm{Wo}_{50} \mathrm{En}_{45} \mathrm{Fs}_{5}$ ). Esta mesma borda se localiza acima do limite da linha Di-Hd do quadrilátero e também é caracterizada por maiores teores de $\mathrm{TiO}_{2}(1,5 \%)$ e menores de $\mathrm{Al}_{2} \mathrm{O}_{3}(6,9 \%)$. As bordas dos cristais do xenólito Ln9h, algumas das quais longe do contato com o lamprófiro, também apresentam por vezes menores teores em $\mathrm{Al}_{2} \mathrm{O}_{3}$.

Diferenças marcantes ocorrem entre os cristais dos xenólitos quanto aos teores de $\mathrm{Al}_{2} \mathrm{O}_{3}$ e $\mathrm{TiO}_{2}$. O clinopiroxênio dos xenólitos Ln9h e Ln9xm3 do grupo 1 (com maior proporção de espinélio) apresenta os maiores teores de $\mathrm{Al}_{2} \mathrm{O}_{3}(6,2$ a $7,6 \%)$ e $\mathrm{TiO}_{2}(0,55$ a 0,76\%). $\mathrm{O}$ gráfico $\mathrm{Al}_{2} \mathrm{O}_{3} \times \mathrm{TiO}_{2}$ (Figura 23a) mostra a correlação positiva entre os dois óxidos. Baixos teores são encontrados nos cristais do xenólito Ln9xm2, mas observa-se que sua borda de reação apresenta um diopsídio com composição distinta, mais rica em $\mathrm{Al}_{2} \mathrm{O}_{3}(3 \%)$ e $\mathrm{TiO}_{2}(0,3 \%)$ e também com teor de $\mathrm{Cr}_{2} \mathrm{O}_{3}$ maior do que o observado em todos os xenólitos (máximo de $1,4 \%$ no xenólito $\mathrm{Ln9h})$. O gráfico $\mathrm{Al}_{2} \mathrm{O}_{3} \times \mathrm{Mg} \#(\mathrm{Mg} /(\mathrm{Mg}+\mathrm{Fe})$ (Figura 23b) mostra correlação com tendência negativa, exceção da análise do xenólito Ln9xm2. Uma correlação positiva bem definida é observada entre $\mathrm{Al}_{2} \mathrm{O}_{3}$ e $\mathrm{Na}_{2} \mathrm{O}$ (Figura 23c) onde os maiores teores deste último óxido são encontrados para Ln9h (1,8 a 2,3\%).

Cristal de clinopiroxênio do lamprófiro se localiza acima do limite da linha Di-Hd do quadrilátero. Esta análise apresenta $5,7 \%$ de $\mathrm{TiO}_{2}, 10 \%$ de $\mathrm{Al}_{2} \mathrm{O}_{3}$ e $8 \%$ de $\mathrm{FeO}_{\mathrm{t}}$, teores bem mais altos que os encontrados em cristais dos xenólitos. Teores mais baixos em relação aos cristais dos xenólitos são encontrados principalmente para $\mathrm{SiO}_{2}(40 \%), \mathrm{Cr}_{2} \mathrm{O}_{3}(0,07 \%)$ e $\mathrm{Na}_{2} \mathrm{O}$ $(0,5 \%)$. Nas bordas de reação também foram encontrados cristais com composição semelhante a esse último cristal e também Ti-augitas com $0,4 \%$ de $\mathrm{TiO}_{2}, 1,8 \%$ de $\mathrm{Al}_{2} \mathrm{O}_{3}$ e $1,6 \% \mathrm{Cr}_{2} \mathrm{O}_{3}$ na borda de ortopiroxênio do xenólito Ln9g. 


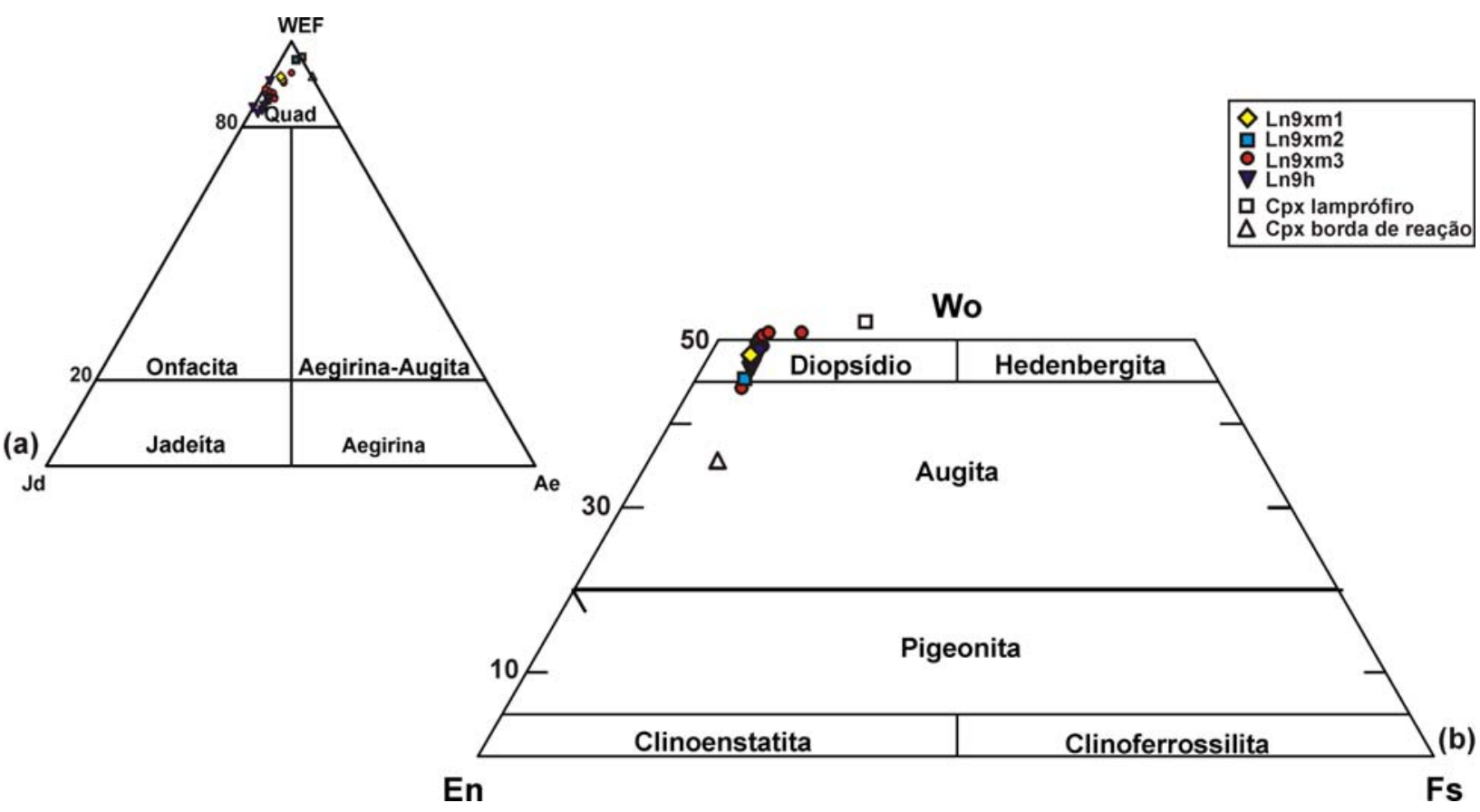

Figura 22: (a) Diagrama de Morimoto (1988) com indicação de que todos os cristais de piroxênio dos xenólitos do manto de Ubatuba devem ser classificados no quadrilátero (Quad). (b) Quadrilátero. Diagrama de Morimoto (1988) com classificação dos cristais de clinopiroxênio.

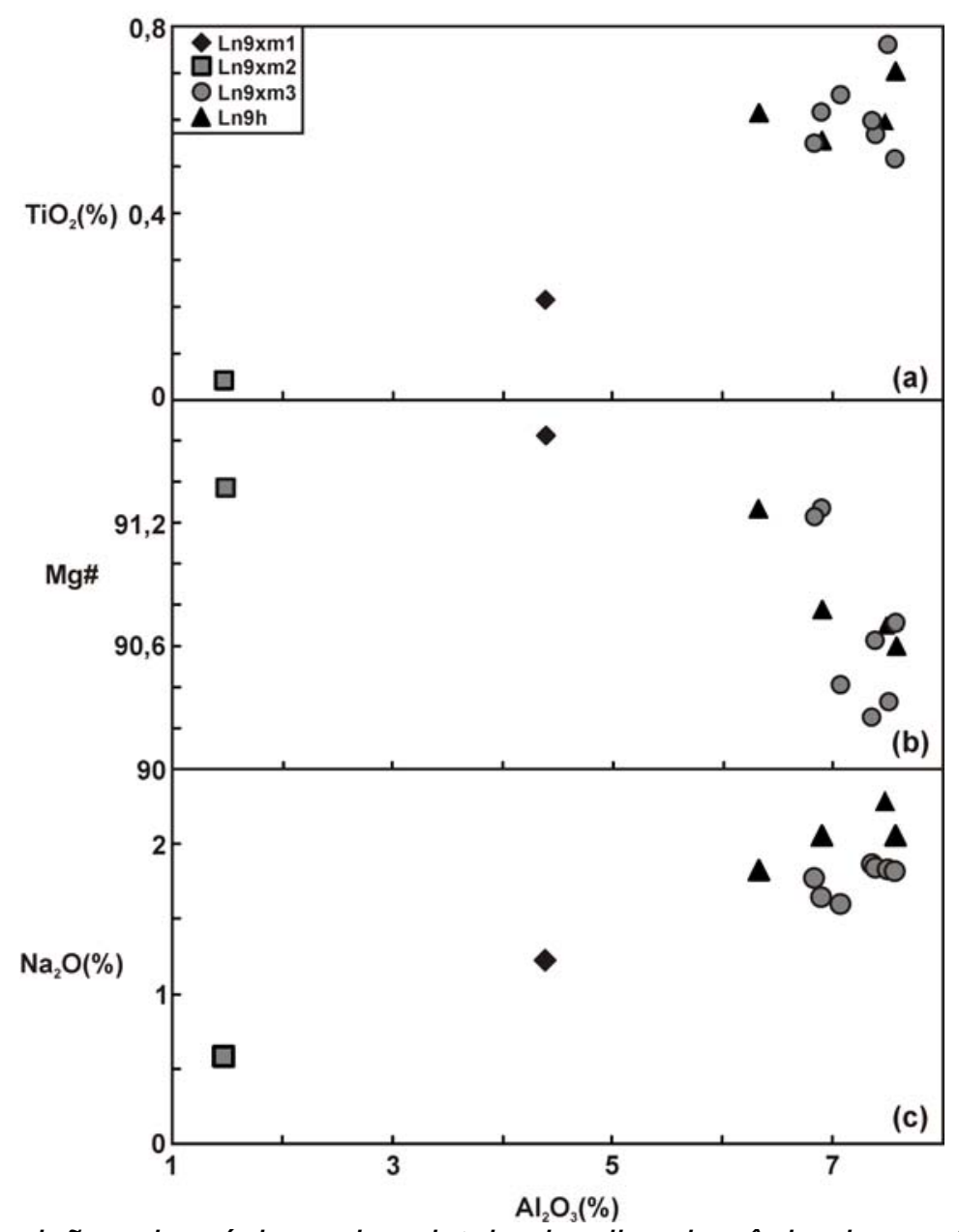

Figura 23: Composições de núcleos de cristais de clinopiroxênio de xenólitos do manto de Ubatuba mostrando correlações positivas entre $\mathrm{Al}_{2} \mathrm{O}_{3}$ e $\mathrm{TiO}_{2}$ (a) e $\mathrm{Al}_{2} \mathrm{O}_{3}$ e $\mathrm{Na}_{2} \mathrm{O}$ (c) e a correlação negativa entre $\mathrm{Al}_{2} \mathrm{O}_{3}$ e $\mathrm{Mg \#}(\mathrm{Mg} /(\mathrm{Mg}+\mathrm{Fe}))(\mathrm{b})$. 


\subsubsection{Espinélio}

Foram analisados cristais de espinélio presentes no grupo 1 (Ln9xm1, Ln9xm3 e Ln9h). Os resultados encontram-se no Anexo 4. O teor de $\mathrm{Fe}_{2} \mathrm{O}_{3}$ foi calculado por meio da razão $\mathrm{Fe}^{2+} / \mathrm{Fe}^{3+}$ estimada pelo procedimento de Carmichael (1967). As composições foram plotadas na Figura 24. No geral, os cristais dos xenólitos Ln9h e Ln9xm3 são bastante aluminosos ( 58 a $61 \%$ de $\left.\mathrm{Al}_{2} \mathrm{O}_{3}\right)$, mas os de $\mathrm{Ln9h}$ apresentam teores maiores de $\mathrm{Cr}_{2} \mathrm{O}_{3}(9,2$ a 9,6\%) em relação a Ln9xm3 (6,2 a 7,7\% de $\left.\mathrm{Cr}_{2} \mathrm{O}_{3}\right)$, e têm portanto maior $\mathrm{Cr} \#(\mathrm{Cr} /(\mathrm{Cr}+\mathrm{Al}))$ e razões $\mathrm{Fe}^{2+} /\left(\mathrm{Fe}^{2+}+\mathrm{Mg}\right)$ por vezes levemente maiores .

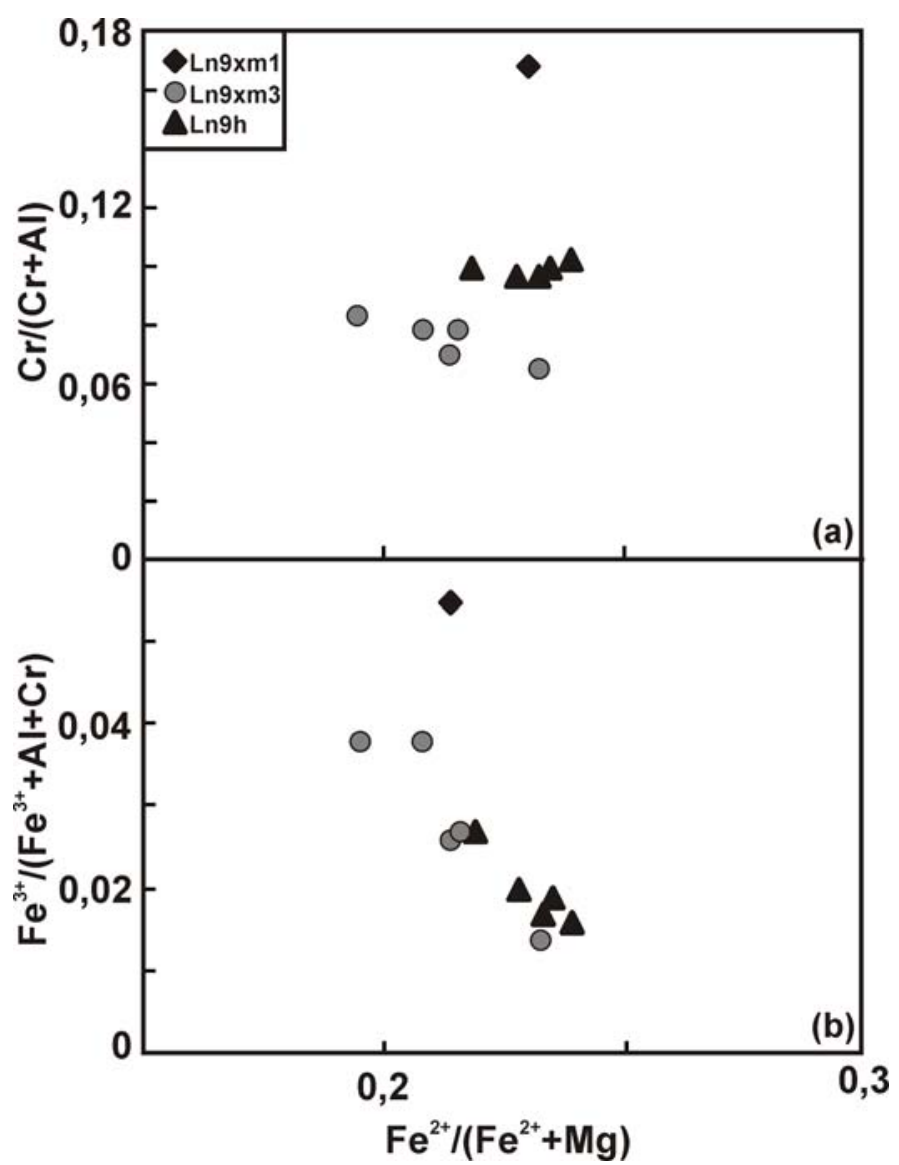

Figura 24: Composições de cristais de espinélio de xenólitos do manto de Ubatuba com relação entre as razões $\mathrm{Fe}^{2+} /\left(\mathrm{Fe}^{2+}+\mathrm{Mg}\right) \operatorname{com~} \mathrm{Cr} /(\mathrm{Cr}+\mathrm{Al})$ (a) e $\mathrm{Fe}^{3+} /\left(\mathrm{Fe} \mathrm{e}^{3+}+\mathrm{Al}+\mathrm{Cr}\right)(\mathrm{b})$.

Os cristais de espinélio do xenólito Ln9xm1 se diferenciam pelo maior $\mathrm{Cr} \#$ em relação aos demais xenólitos, refletindo tanto o maior teor de $\mathrm{Cr}_{2} \mathrm{O}_{3}(15 \%)$ como o menor teor de $\mathrm{Al}_{2} \mathrm{O}_{3}$ (50\%). Como já citado na petrografia, a seção petrográfica deste xenólito apresentou apenas um cristal de espinélio que está localizado próximo ao contato com o lamprófiro. É importante observar que tanto o clinopiroxênio como o ortopiroxênio deste xenólito também apresentam menores teores de $\mathrm{Al}_{2} \mathrm{O}_{3}$ em relação aos xenólitos Ln9h e Ln9xm3. 
A razão $\mathrm{Fe}^{3+} /\left(\mathrm{Fe}^{3+}+\mathrm{Al}+\mathrm{Cr}\right)$ do espinélio dos xenólitos $\mathrm{Ln9h}$ e Ln9xm3 é bastante variável, porém é sempre menor que a do espinélio de Ln9xm1, que tem maior teor de $\mathrm{Fe}_{2} \mathrm{O}_{3 \text { calculado }}(5,4 \%)$. Teores de $\mathrm{TiO}_{2}$ são baixos, com máximo de $0,15 \%$ na borda de cristal de Ln9xm3.

A classificação dos xenólitos tem sido feita por alguns autores por meio do Cr\# dos cristais de espinélio. Segundo Fodor et al. (2002) o $\mathrm{Cr} \#(\mathrm{Cr} /(\mathrm{Cr}+\mathrm{Al}))$ maior que 0,3 define o campo de harzburgitos com clinopiroxênio (clinopyroxene-bearing harzburgite), enquanto $\mathrm{Cr} \#$ menor que 0,3 define o campo dos Iherzolitos. No caso dos xenólitos de Ubatuba, todas as amostras portadoras de espinélio se encaixam no campo dos Iherzolitos, já que os Cr\# são menores que 0,18. Arai (1994) considera que os Cr\# menores que 0,2 representam Iherzolitos férteis. As análises também se encaixam no campo definido por Barnes \& Roeder (2001) para espinélio de xenólitos de basaltos alcalinos (Figura 25).

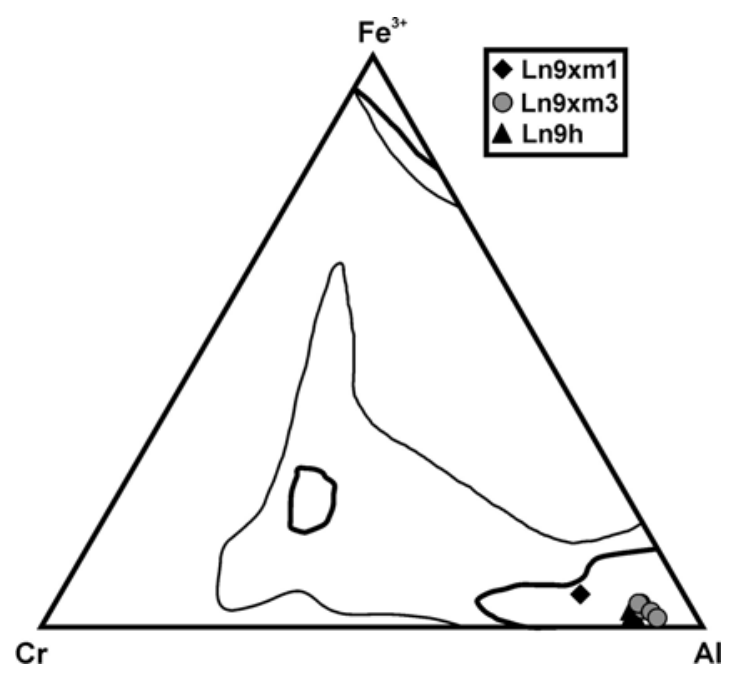

Figura 25: Diagrama ternário de Barnes \& Roeder (2001) para cristais de espinélio em xenólitos de basaltos alcalinos. As linhas mais fortes indicam regiões com maior concentração de análises.

\subsubsection{Análises semi-quantitativas por EDS em fases acessórias}

Análises semi-quantitativas por EDS foram feitas no microscópio eletrônico de varredura (MEV) com o objetivo de classificar cristais de minerais opacos identificados na microscopia óptica. As únicas fases encontradas foram sulfetos de Fe e Ni (provável pentlandita, com 33\% $\mathrm{Fe}$ e $\sim 12 \% \mathrm{Ni}$, em proporção atômica). Imagem de elétrons retroespalhados (BSE) foi feita em um dos cristais, mostrando uma heterogeneidade composicional sob a forma de lamelas escuras e regiões mais claras dentro do cristal (Figura 26). 


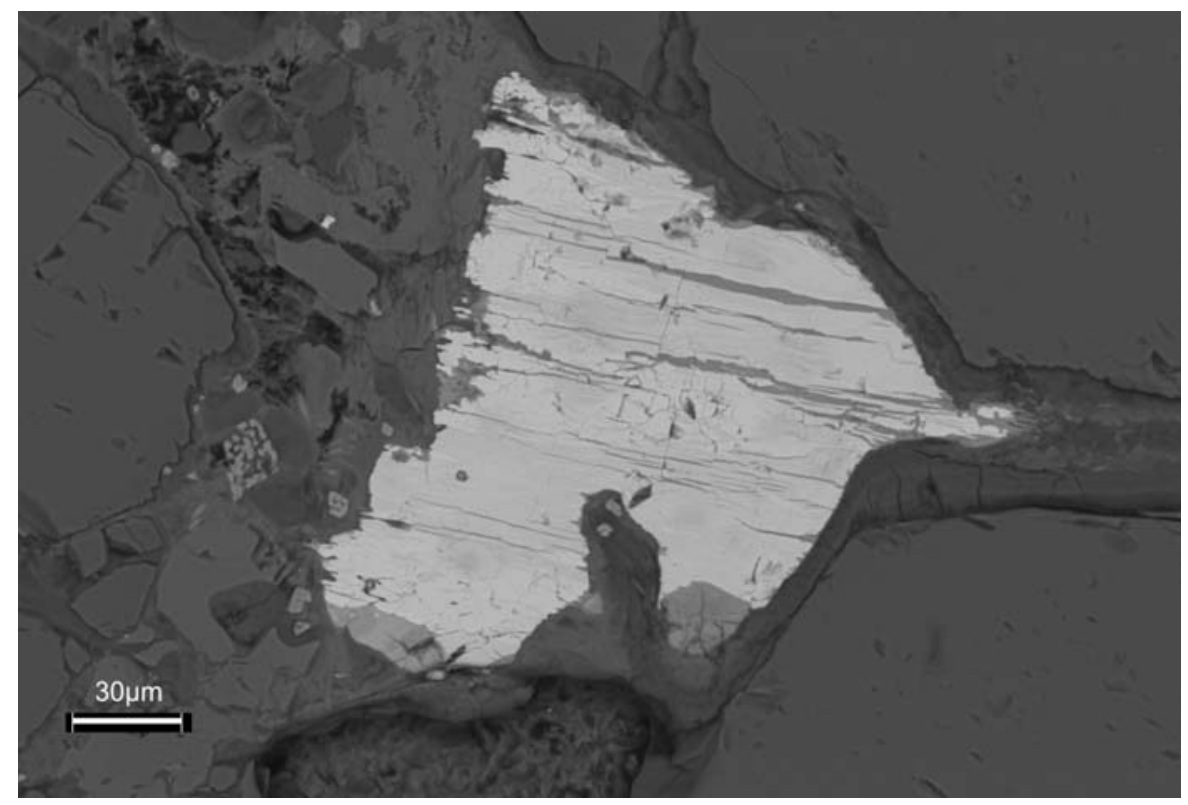

Figura 26: Imagem BSE de sulfeto de $\mathrm{Fe}$ e Ni do xenólito Ln9h.

\subsection{Geoquímica de elementos-traços em minerais}

\subsubsection{Residência dos elementos traços em espinélio peridotitos}

As estruturas cristalinas dos minerais do manto superior (silicatos e espinélio) são desfavoráveis para íons litófilos com grande raio iônico (e.g. K, Rb, Cs, Ba, Th, U) e para alguns elementos HFS (high field strength) (Ti, V, Nb, Ta) (Bedini \& Bodinier, 1999). Entre os minerais mantélicos dominantes, apenas o clinopiroxênio é considerado um hospedeiro significativo de elementos altamente incompatíveis. No entanto, alguns elementos traços como HFS e P podem estar distribuídos em mais de uma fase mineral, o que acrescenta importância ao estudo da composição de ortopiroxênio, olivina e espinélio em espinélio peridotitos. Fases acessórias como anfibólio, flogopita, apatita e titanatos, inclusões fluidas e bordas de grãos também podem representar significativos reservatórios de elementos traços.

Elementos incompatíveis trivalentes, como os elementos terras raras (ETR) (Blundy \& Wood, 2003) substituem principalmente $\mathrm{Ca}^{2+}$ no sítio octaédrico M2 do clinopiroxênio. Esta substituição é sensível a pequenas variações na composição deste mineral e bastante dependente da concentração de Al tetraédrico (Blundy \& Wood, 2003). Elementos como Sr, Ba e $\mathrm{Pb}$ formam íons bivalentes com grande raio iônico e substituem $\mathrm{Ca}^{2+}$ (Witt-Eickshen et al., 2005). Ti e outros elementos HFS, de alta carga ( $\mathrm{Ta}, \mathrm{Zr}, \mathrm{Hf}, \mathrm{Nb}$ ), substituem Mg e Fe ${ }^{2+}$ no sítio octaédrico M1 (McDonough et al., 1991).

A ocorrência de substituições heterovalentes induz substituições adicionais para balanço de carga. Um exemplo é a incorporação de lantanídeos trivalentes $\left(\mathrm{ETR}^{3+}\right)$ no sítio M2 
do clinopiroxênio, normalmente ocupado pelos bivalentes $\mathrm{Ca}$ e $\mathrm{Mg}$. Esta incorporação necessita de uma compensação de carga em outro local do retículo, dada, por exemplo, pelas substituições $\mathrm{ETR}^{3+}+\mathrm{Na}^{+}=2 \mathrm{Ca}^{2+}$ (Blundy \& Wood, 2003) ou Al no lugar de Si (Witt-Eickshen et al., 2005). Um outro exemplo consiste na substituição de Ti em piroxênios, que envolve a entrada da molécula $\mathrm{CaTiAl}_{2} \mathrm{O}_{6}$ com substituição por $\mathrm{Al}$ no sítio tetraédrico, Ca no sítio M2 e Ti no sítio M1 (McDonough et al., 1991).

Diferenças na composição do clinopiroxênio podem levar ao fracionamento de elementos traços. Composições ricas em Ca apresentam sítios M2 com dimensão similar ao íon $\mathrm{Ca}^{2+}$, o que facilita a incorporação do íon $\mathrm{Th}^{4+}(1,05 \AA)$ em relação a $\mathrm{U}^{4+}(1,00 \AA)$ (Blundy \& Wood, 2003).

O ortopiroxênio apresenta os sítios octaédricos maior (M2) e menor (M1) comumente ocupados por Fe e Mg. O sítio M1 possui dimensão similar ao seu correspondente M1 do clinopiroxênio, porém o sítio M2 é menor em relação ao equivalente M2 do clinopiroxênio (Wood \& Blundy, 2003).

Lantanídeos são mais incompatíveis na estrutura do ortopiroxênio em relação ao clinopiroxênio. No entanto, segundo Witt-Eickshen et al. (2005), os valores de coeficientes de partição de ETR entre os dois minerais $\left(D^{\mathrm{cpx} / \mathrm{opx}}\right)$ diminuem sistematicamente com o aumento do número atômico, e em condições anidras (dry solidus) o $D^{\mathrm{cpx} / \mathrm{opx}}$ pode ser tão baixo quanto 2 a 3 para ETRP (elementos terras-raras pesados). No caso de resíduos anidros de fusão parcial com baixa razão modal cpx/opx, como peridotitos abissais, o ortopiroxênio pode apresentar maiores teores em ETRP e até em ETRL (elementos terras-raras leves) em relação ao clinopiroxênio.

Elementos HFS (e.g. Ti) também podem estar mais concentrados em ortopiroxênio em relação ao clinopiroxênio, como observado por McDonough et al. (1991).

A olivina, assim como o espinélio, apresenta estrutura incompatível para ETR e outros elementos traços. No entanto, em peridotitos altamente empobrecidos, a olivina pode apresentar maiores teores em ETRP em relação ao clinopiroxênio (Witt-Eickshen et al., 2005). Teores significativos de $\mathrm{P}$ também podem estar presentes na olivina, que é, juntamente com o clinopiroxênio, reservatório dominante de $\mathrm{P}$ entre os minerais essenciais de espinélio peridotitos anidros (McDonough et al., 1991).

\subsubsection{Análises de elementos traços por LA-ICPMS}

Foram analisados cristais de olivina, ortopiroxênio e clinopiroxênio nos xenólitos dos grupos 1 (Ln9xm1 e Ln9xm3) e 2 (Ln9xm2) por LA-ICPMS, selecionados a partir da análise das texturas e da química de elementos maiores por microssonda eletrônica. 


\section{Olivina}

Os resultados obtidos nas análises de elementos traços em olivina são apresentados no Anexo 11. Boa parte dos elementos litófilos de grande raio iônico (LILE) (e.g. Rb, Ba, Sr, ETRL) e alguns HFS (e.g. $\mathrm{Zr}, \mathrm{Nb}$ ) apresentam teores muito baixos, na maioria das vezes abaixo do limite de detecção (I.d.). Elementos terras-raras pesados (ETRP) apresentam por vezes teores acima do I.d., com destaque para uma concentração de Gd do xenólito Ln9xm3 com 0,2 ppm.

Os teores mais significativos são encontrados para $\mathrm{P}, \mathrm{Ti}, \mathrm{Mn}, \mathrm{V}, \mathrm{Cr}$, Co, Ni e Zn. A olivina do xenólito Ln9xm3 caracteriza-se por apresentar maiores concentrações de Ti (até 35 ppm, contra 4 a 5 ppm nos demais) e P (até 74 ppm, contra 57 a 68 ppm). A olivina de Ln9xm1 tem maior concentração de $\mathrm{P}$ em relação ao ortopiroxênio, com $C_{o p x} / C_{o l}$ (concentração no ortopiroxênio / concentração na olivina) de cerca de 0,75 , sendo o segundo principal hospedeiro, depois do clinopiroxênio, deste elemento. A olivina desse xenólito também se destaca por apresentar maiores concentrações de Ni (até 3335 ppm), Cr (até 25 ppm, contra 8 ppm em Ln9xm3), V (até 1,5 ppm), Cu (até 1 ppm). A olivina de Ln9xm2 (grupo 2) apresenta alto teor de $\mathrm{Zn}$ ( 120 ppm contra 33 a 45 ppm nos demais). A distribuição $C_{o p x} / C_{o l}$ para $\mathrm{Ni}, \mathrm{Zn}$, Co e Cu tem valores inferiores a $1(\sim 0,2$ para Ni, 0,8 para $\mathrm{Zn}, 0,4$ para Co e 0,7 para $\mathrm{Cu})$ nos xenólitos Ln9xm1 e Ln9xm3, o que também se observa para a distribuição $C_{c p x} / C_{o l}$ para esses mesmos elementos.

\section{Ortopiroxênio}

Cristais de ortopiroxênio dos xenólitos do grupo 1 (Ln9xm1 e Ln9xm3) foram analisados. Os resultados das análises encontram-se no Anexo 12. A maioria dos LILE apresentou baixos teores, alguns abaixo do limite de detecção (e.g. Rb). O ortopiroxênio do xenólito Ln9xm1 é mais rico em LILE (Ba e Sr com até 0,7 e 1,2 ppm, respectivamente) e ETRL (até $0,1 \mathrm{ppm}$ de La e 0,2 ppm de $\mathrm{Ce}$ ) com teores cerca de 10 vezes superiores aos do ortopiroxênio de Ln9xm3, este no entanto, apresenta maiores concentrações de $P$ (até 86 ppm), V (até $106 \mathrm{ppm}$ ), Co (até $60 \mathrm{ppm}$ ), Ni (até $688 \mathrm{ppm}$ ), Ga (até $4 \mathrm{ppm}$ ), Zr (até 0,9 ppm) e $\mathrm{Y}$ (até $0,9 \mathrm{ppm})$. Entre os ETRP, os teores maiores são de $\mathrm{Yb}(\sim 0,2 \mathrm{ppm}$ em ambos os xenólitos).

\section{Clinopiroxênio}

Os cristais de clinopiroxênio foram analisados nos xenólitos dos grupos 1 (Ln9xm1 e Ln9xm3) e 2 (Ln9xm2). As análises encontram-se no Anexo 13. O clinopiroxênio é o principal 
hospedeiro de LILE e elementos HFS, enquanto os elementos $\mathrm{Mn}$, Co, $\mathrm{Ni}$ e $\mathrm{Zn}$ se concentram preferencialmente na olivina e ortopiroxênio.

Os cristais analisados do xenólito do grupo 2 (Ln9xm2), que se encontram em desequilíbrio textural com as demais fases, são os mais enriquecidos em elementos incompatíveis como ETRL ( 18 ppm de La e $\sim 80$ ppm de Ce) e HFS ( $\sim 2$ ppm de Zr). Inclusões ou zoneamentos químicos envolvendo principalmente $\mathrm{Rb}, \mathrm{Ba}, \mathrm{Sr}$ e $\mathrm{Nb}$ foram identificados neste xenólito por meio do exame da variação da forma dos picos no perfil analítico observado no software Glitter. No clinopiroxênio de Ln9xm1, as inclusões ou zoneamentos identificados envolvem $\mathrm{Ba}$ e muito provavelmente $\mathrm{Sr}$, como indicado pelo significativo aumento dos teores desses elementos em porções de alguns cristais.

Diferenças nos teores de ETR entre orto e clinopiroxênio apontam razões $C_{c p x} / C_{o p x}$ muito altas (206 para Ce e cerca de 15 para $\mathrm{Yb}$ ) para esses elementos.

Entre os cristais de clinopiroxênio do grupo 1, os de Ln9xm1 (com menor proporção de espinélio) apresentam maiores concentrações de ETRL (até 22,5 ppm de La e 32,6 ppm de Ce) e Pb (até 3 ppm) e menores de Y (até 9 ppm) e ETRP (até 1,3 ppm de Yb e 0,2 ppm de Lu) se comparados aos de Ln9xm3 (até 2,8 ppm de La, 9,3 ppm de Ce, 0,5 ppm de Pb, 19 ppm de Y, 3 ppm de Yb e 0,4 ppm de Lu).

Razões LILE/HFS representadas pelos pares La/Nb e La/Zr (Figura 27) apresentaram altos valores no Ln9xm1 mostrando o enriquecimento de LILE. As análises do xenólito Ln9xm2 não foram consideradas devido à existência de inclusões ou zoneamentos envolvendo $\mathrm{Nb}$.

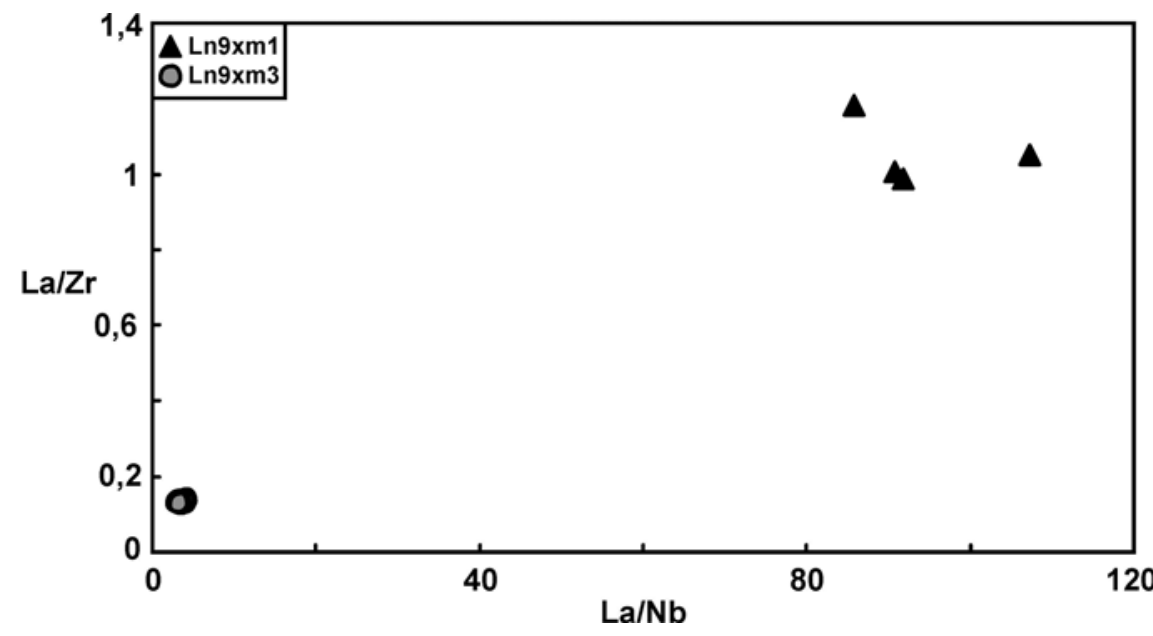

Figura 27: Razões LILE/HFS (La/Nb e La/Zr) dos cristais de clinopiroxênio.

Os padrões de elementos terras-raras normalizados pelo condrito $\mathrm{C} 1$ de Mcdonough \& Sun (1995) são apresentados na Figura 28. Os clinopiroxênios do xenólito Ln9xm3 (com Mg\# = 90,2 a 91,3) apresentam padrões praticamente planos por vezes com empobrecimento muito leve em ETRL, com razões $(\mathrm{La} / \mathrm{Yb})_{N}$ de 0,6 a 1 e concentrações da ordem de 10 vezes o condrito. Já nos outros dois xenólitos, existe notável enriquecimento de ETRL, porém com padrões distintos (Figura 28), sendo as razões $(\mathrm{La} / \mathrm{Yb})_{N}$ maiores em Ln9xm1 (9 a 15 contra $\sim 3$ 
em Ln9xm2). O enriquecimento observado no clinopiroxênio de Ln9xm1 (Mg\# = 91,6) é restrito aos ETRL, já que entre os terras-raras médios e pesados os padrões são praticamente planos, com razões $(\mathrm{Gd} / \mathrm{Lu})_{\mathrm{N}}$ de 0,8 a 1,4 e concentrações cerca de 6 vezes o condrito. O clinopiroxênio de Ln9xm2 (Mg\# = 91,4) é o mais enriquecido, mas apresenta padrão ETR peculiar, com forma convexa entre os ETRL, com pico no $\mathrm{Nd}$ (com razão $(\mathrm{La} / \mathrm{Nd})_{\mathrm{N}}<1$ ). Discretas anomalias positivas de $\mathrm{Eu}\left(\mathrm{Eu}_{N} / \mathrm{Eu}^{*}=1,1\right.$ a 1,3 , onde $\left.\left.E u^{*}=\left(\mathrm{Sm}_{N}+\mathrm{Gd}_{N}\right) / 2\right)\right)$ são esboçadas no clinopiroxênio de Ln9xm1.

Os padrões de elementos incompatíveis normalizados pelo manto primitivo de Sun \& Mcdonough (1989) são apresentados na Figura 29.

O clinopiroxênio de Ln9xm3 tem padrão mais regular, com teores em torno de 5 vezes o condrito perturbado por discretas anomalias negativas de $\mathrm{Zr}$ e Hf (razões $(\mathrm{Sm} / \mathrm{Zr})_{\mathrm{N}}=1,8$ a 3,2), $\left.\mathrm{Sr}(\mathrm{Nd} / \mathrm{Sr})_{\mathrm{N}}=1 \mathrm{a} 1,2\right)$ e destacado empobrecimento de elementos LILE e $\mathrm{Nb}(\mathrm{La} / \mathrm{Nb})_{\mathrm{N}}=3,2 \mathrm{a}$ $4,3)$.

O clinopiroxênio de Ln9xm1 é mais pobre em elementos menos incompatíveis que o Eu (Figura 29), com destaque para uma anomalia negativa de $\mathrm{Ti}$ bem definida $\left((\mathrm{Gd} / \mathrm{Ti})_{\mathrm{N}}=1,9\right.$ a 2,6), e notável enriquecimento em elementos mais incompatíveis que o $\mathrm{Nd}$, à exceção do $\mathrm{Nb}$ (a razão La/Nb é excepcionalmente alta, $\sim 90$ a 100). Uma discreta anomalia positiva de $\mathrm{Sr}$ também é perceptível $\left((\mathrm{Nd} / \mathrm{Sr})_{\mathrm{N}}<1\right)$.

O padrão do clinopiroxênio de Ln9xm2 é enriquecido na maior parte dos elementos incompatíveis, com a exceção notável de $\mathrm{Ti}$, gerando-se uma forte anomalia negativa com $(\mathrm{Gd} / \mathrm{Ti})_{\mathrm{N}}$ de 32 e, em parte, os LILE (e.g. Ba, Th). O enriquecimento de Sr e Zr-Hf é mais discreto que o dos elementos vizinhos, resultando em maiores razões $\mathrm{Nd} / \mathrm{Sr}$ e $\mathrm{Sm} / \mathrm{Zr}$.

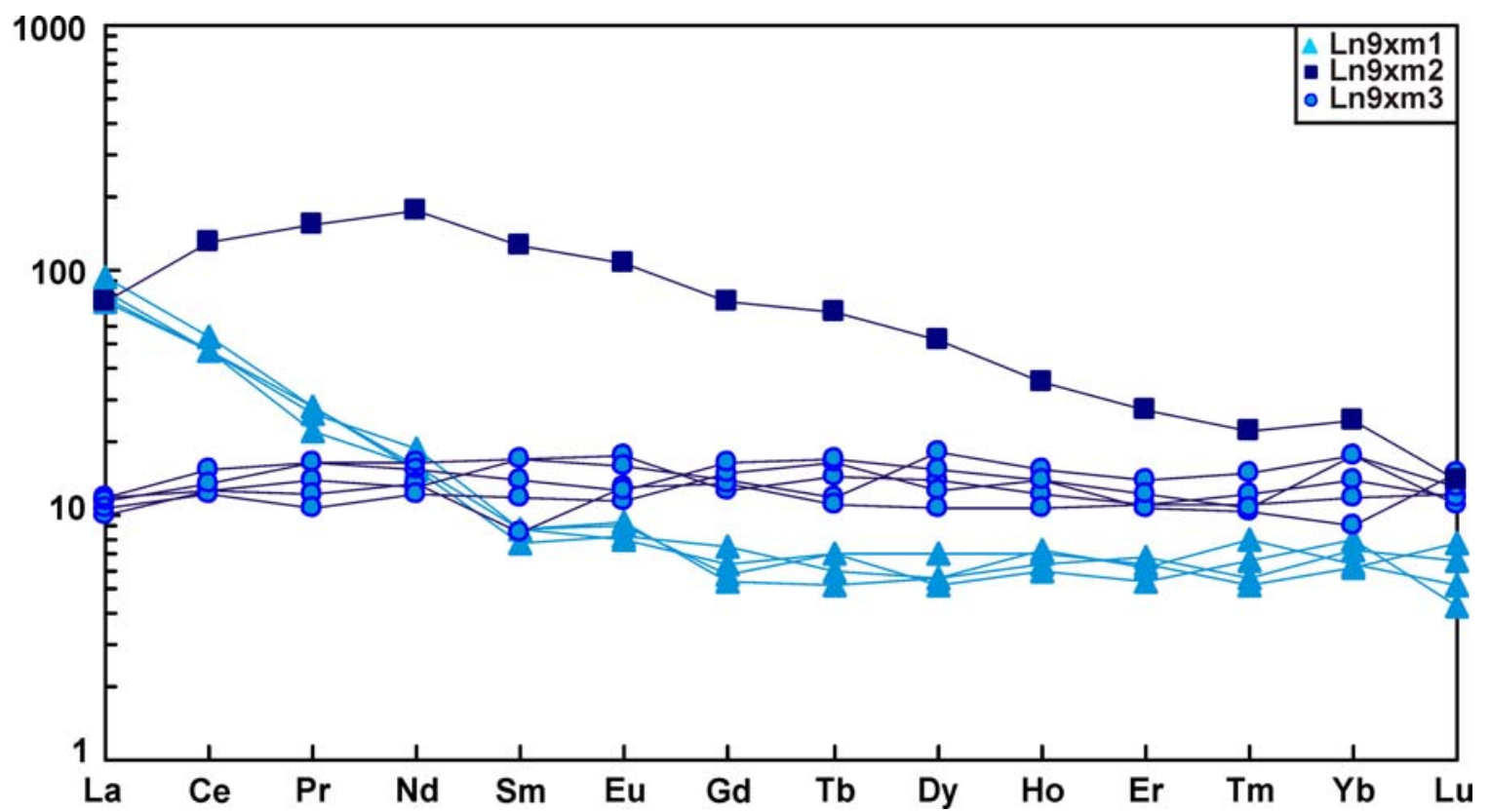

Figura 28: Padrões de elementos terras-raras de cristais de clinopiroxênio de xenólitos de Ubatuba normalizados ao padrão condrítico C1 de McDonough \& Sun (1995). 


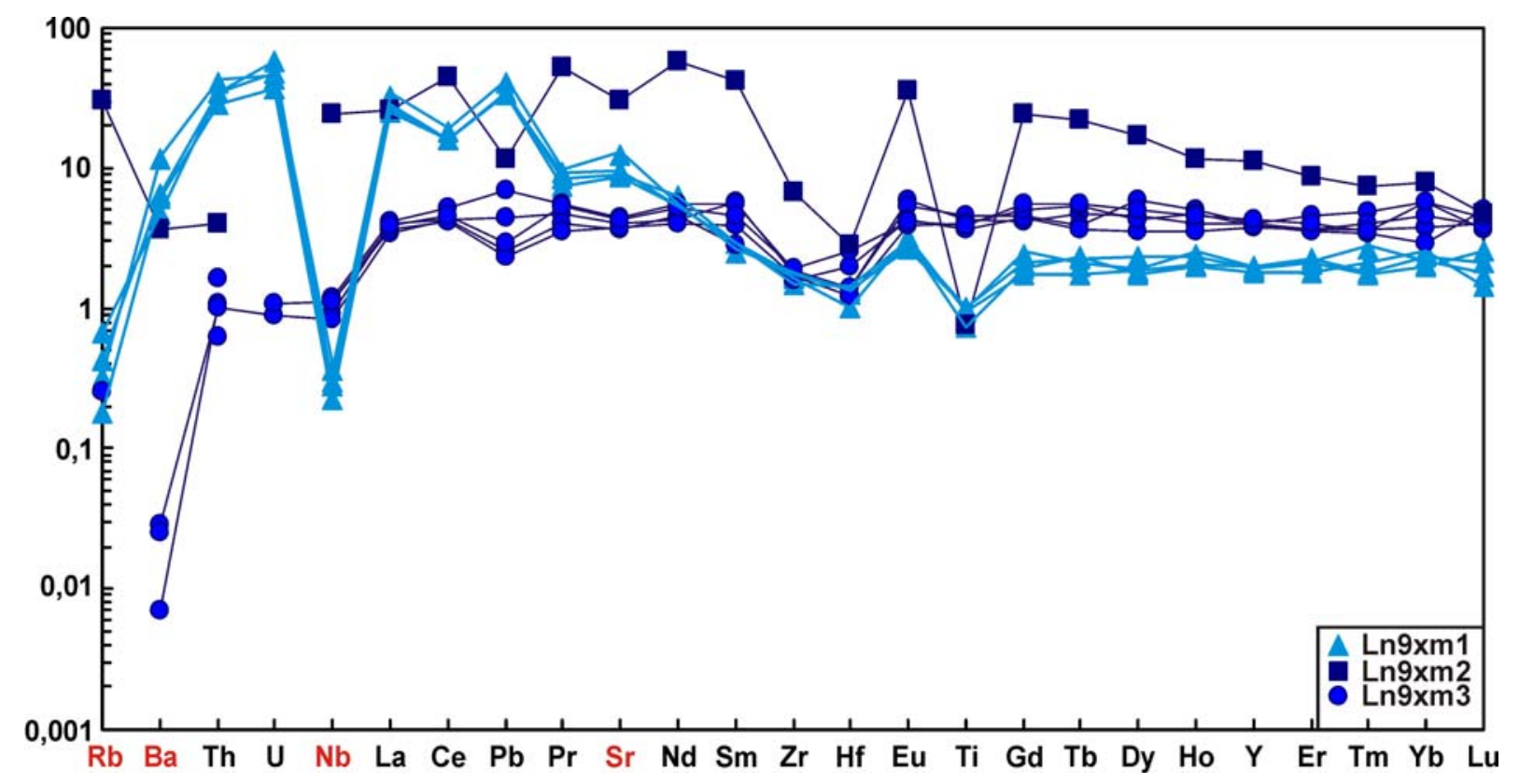

Figura 29: Padrões de elementos incompatíveis de cristais de clinopiroxênio de xenólitos de Ubatuba normalizados pelo manto primitivo de Sun \& Mcdonough (1989). Elementos relacionados às inclusões ou zoneamentos encontram-se em vermelho na escala (Ba e Sr para Ln9xm1 e Rb, Ba, Sr e Nb para Ln9xm2).

\subsection{Petrogênese}

\subsubsection{Estimativas de temperatura}

Estimativas de temperatura de equilíbrio foram feitas por meio de análises químicas de cristais dos xenólitos. Para isso foi utilizado o programa PTEXL criado por T. Koehler e A. Girnis (disponível em http://www.mineralogie.uni-frankfurt.de). O programa calcula temperaturas e pressões de rochas mantélicas a partir das composições dos minerais coexistentes em porcentagem em peso. Cristais de quatro xenólitos de Ubatuba foram utilizados para essas estimativas, e os resultados se encontram na Tabela 4. Os geotermômetros utilizados envolvem a transferência do componente $\mathrm{MgSiO}_{3}$ (enstatita) entre orto e clinopiroxênio coexistentes (Brey \& Koehler, 1990; Wells, 1977; Bertrand \& Merrier, 1985), o teor de Ca em ortopiroxênio (Brey \& Koehler, 1990), troca de Fe-Mg entre olivina e espinélio (Ballhaus, 1991; O’Neill \& Wall, 1987) e Al em ortopiroxênio (Witt-Eickshen, 1991). Cada metodologia e calibração forneceram resultados diferentes. No xenólito Ln9xm2 (grupo 2) foram feitas apenas estimativas baseadas nos teores de $\mathrm{Ca}$ e $\mathrm{Al}$ em ortopiroxênio, dada a textura de desequilíbrio em que o clinopiroxênio se encontra. 
Tabela 4: Temperaturas estimadas para xenólitos de Ubatuba. Temperatura em ${ }^{\circ} \mathrm{C}$ calculada por meio da média das composições dos núcleos dos cristais.

\begin{tabular}{|c|c|c|c|c|c|}
\hline Metodologia & Calibração & $\begin{array}{l}\text { Ln9xm1 } \\
\text { (Grupo 1) }\end{array}$ & $\begin{array}{l}\text { Ln9xm3 } \\
\text { (Grupo 1) }\end{array}$ & $\begin{array}{c}\text { Ln9h } \\
\text { (Grupo 1) }\end{array}$ & $\begin{array}{l}\text { Ln9xm2 } \\
\text { (Grupo 2) }\end{array}$ \\
\hline \multirow[t]{3}{*}{ Opx-Cpx } & $\begin{array}{l}\text { BKN (Brey \& Koehler, } \\
1990)\end{array}$ & 750 & 860 & 947 & \\
\hline & Wells (1977) & 812 & 855 & 899 & \\
\hline & Bertrand \& Merrier (1985) & 721 & 809 & 892 & \\
\hline Ca em Opx & Brey \& Koehler (1990) & 882 & 815 & 815 & 830 \\
\hline \multirow{2}{*}{$\begin{array}{l}\text { Troca de Fe-Mg entre Ol e } \\
\text { Sp }\end{array}$} & Ballhaus (1991) & 911 & 886 & 774 & \\
\hline & O’Neill \& Wall (1987) & 858 & 811 & 710 & \\
\hline Al em Opx & Witt-Eickshen (1991) & 987 & 942 & 908 & 847 \\
\hline
\end{tabular}

Segundo Brey \& Koehler (1990) termômetros baseados em reações de troca e transferência entre minerais são menos dependentes de efeitos composicionais já que são baseados em mais de um parâmetro químico. Seguindo esse princípio foi dada maior relevância aos resultados obtidos em $T_{\text {BKN }}$ e $T_{\text {Wells, }}$, duas calibrações amplamente utilizadas na literatura recente. Maiores temperaturas foram estimadas no espinélio Iherzolito Ln9h (grupo 1) ( $\mathrm{T}_{\mathrm{BKN}} 947^{\circ} \mathrm{C}$ e $\mathrm{T}_{\text {Wells }} 899^{\circ} \mathrm{C}$, a partir da média de composição dos núcleos dos cristais). No caso de Ln9xm3 as calibrações $\mathrm{T}_{\mathrm{BKN}} \mathrm{e} \mathrm{T}_{\text {Wells }}$ apresentaram praticamente o mesmo resultado $\left(860^{\circ} \mathrm{C} \mathrm{e}\right.$ $855^{\circ} \mathrm{C}$, respectivamente). No entanto, a calibração $\mathrm{T}_{\mathrm{BKN}}$ para Ln9h mostrou uma temperatura bem maior $\left(947^{\circ} \mathrm{C}\right)$ em relação à obtida em $T_{\text {Wells }}$ que mostra um aumento mais progressivo de temperatura entre Ln9xm1, Ln9xm3 e Ln9h. Relação contrária é observada nas calibrações de Brey \& Koehler (1990) (Ca em opx), Ballhaus (1991), O’Neill \& Wall (1987) e Witt-Eickshen (1991).

A calibração de Bertrand \& Merrier apresentou valores menores para os três xenólitos $\left(721^{\circ} \mathrm{C}\right.$ para Ln9xm1, $809^{\circ} \mathrm{C}$ para Ln9xm3 e $892^{\circ} \mathrm{C}$ para Ln9h). A calibração de Witt-Eickshen (1991) apresentou valores maiores para os xenólitos Ln9xm1 $\left(987^{\circ} \mathrm{C}\right)$ e $\operatorname{Ln} 9 x \mathrm{xm} 3\left(942^{\circ} \mathrm{C}\right)$ contrastando com as menores temperaturas de $T_{\mathrm{BKN}}$ e $\mathrm{T}_{\text {Wells. }}$. Para o xenólito Ln9xm2 (grupo 2) a temperatura por esse método $\left(847^{\circ} \mathrm{C}\right)$ foi maior em relação à de Brey \& Koehler (1990) (Ca em ortopiroxênio) $\left(830^{\circ} \mathrm{C}\right)$.

A pressão não foi calculada, uma vez que reconhecidamente não existem geobarômetros adequados para essas estimativas em peridotitos da fácies espinélio. Observase, de qualquer modo, que conforme a Figura 3, a pressão máxima para a fácies espinélio seria da ordem de $17 \mathrm{kbar}$ para temperaturas da ordem de $800-900^{\circ} \mathrm{C}$, como as estimadas para os xenólitos estudados. 


\subsubsection{Modelos de fusão em equilíbrio e fusão fracionada}

A composição do clinopiroxênio pode refletir tanto processos de enriquecimento metassomático como processos de empobrecimento por fusão parcial no manto superior por fusão em equilíbrio (i) e fusão fracionada (ii). Em (i) o fundido gerado permanece em contato constante com os cristais residuais, e assim a composição total permanece a mesma, enquanto em (ii) o fundido deixa o sistema assim que é formado, o que muda continuamente a composição total do sólido residual (http://quake.mit.edu). Análises de rocha total podem dimensionar esses processos, porém análises in situ de minerais constituem uma ferramenta mais confiável (Bianchinni et al., 2007).

As composições químicas de elementos traços de cristais de diopsídio do grupo 1 (xenólitos Ln9xm1 e Ln9xm3) foram submetidas aos modelamentos de fusão em equilíbrio e fusão fracionada por meio das equações descritas em Norman et al. (1998):

$$
\begin{array}{ll}
C_{c p x}=\left(D_{c p x} * C_{o}\right) /\left(D_{c p x} * X_{c p x} *(1-f)+f\right) & \text { fusão em equilíbrio (batch) } \\
C_{c p x}=\left(C_{o} / X_{c p x}\right) *(1-f)^{[1 / D c p x x c p x]-1} & \text { fusão fracionada }
\end{array}
$$

Onde:

$\boldsymbol{C}_{c p x}$ é a concentração do elemento traço no diopsídio residual.

$\boldsymbol{C}_{o}$ é a composição inicial da fonte $=3$ x condrito carbonáceo C1 de Anders \& Grevesse (1989).

$X_{c p x}$ é a fração molar de diopsídio na fonte (assumida como 0,2).

$D_{c p x}$ é o coeficiente de distribuição cristal/líquido do elemento traço no diopsídio. Foram utlilizados os mesmos valores de Norman et al. (1998): Y 0,42; Yb 0,40; Th 0,035; Nb 0,005; La 0,055; Ce 0,075; Sr 0,10; Nd 0,15; Zr 0,12; Hf 0,20; Sm 0,25; Eu 0,30; Ti 0,35; Gd 0,40; Dy 0,45; Ho 0,45; Er 0,45; Lu 0,35.

$f$ é o grau de fusão parcial.

O modelamento assume que o clinopiroxênio é o principal hospedeiro de elementos traços na fase sólida residual e que a fusão parcial se deu estritamente em fácies espinélio (Norman et al., 1998). Os elementos $\mathrm{Y}$ e Yb foram usados nos cálculos por serem elementos amplamente utilizados para esse fim (e.g. Norman et al., 1998; Beard et al. 2007) e por apresentarem menor relação com a composição de fluidos/fundidos metassomáticos.

As análises do xenólito Ln9xm3 se encaixaram melhor ao modelo e são compatíveis com apenas 2 a $3 \%$ de fusão em equilíbrio (Figura 30a), valores semelhantes aos calculados por fusão fracionada (Figura 30b). As análises do xenólito Ln9xm1 são compatíveis com cerca de $15 \%$ de fusão em equilíbrio (Figura 30a) e 8 a $9 \%$ de fusão fracionada (Figura 30b). Norman et al. (1998) constatou que para um baixo grau de fusão os dados de fusão em equilíbrio são semelhantes aos de fusão fracionada. 


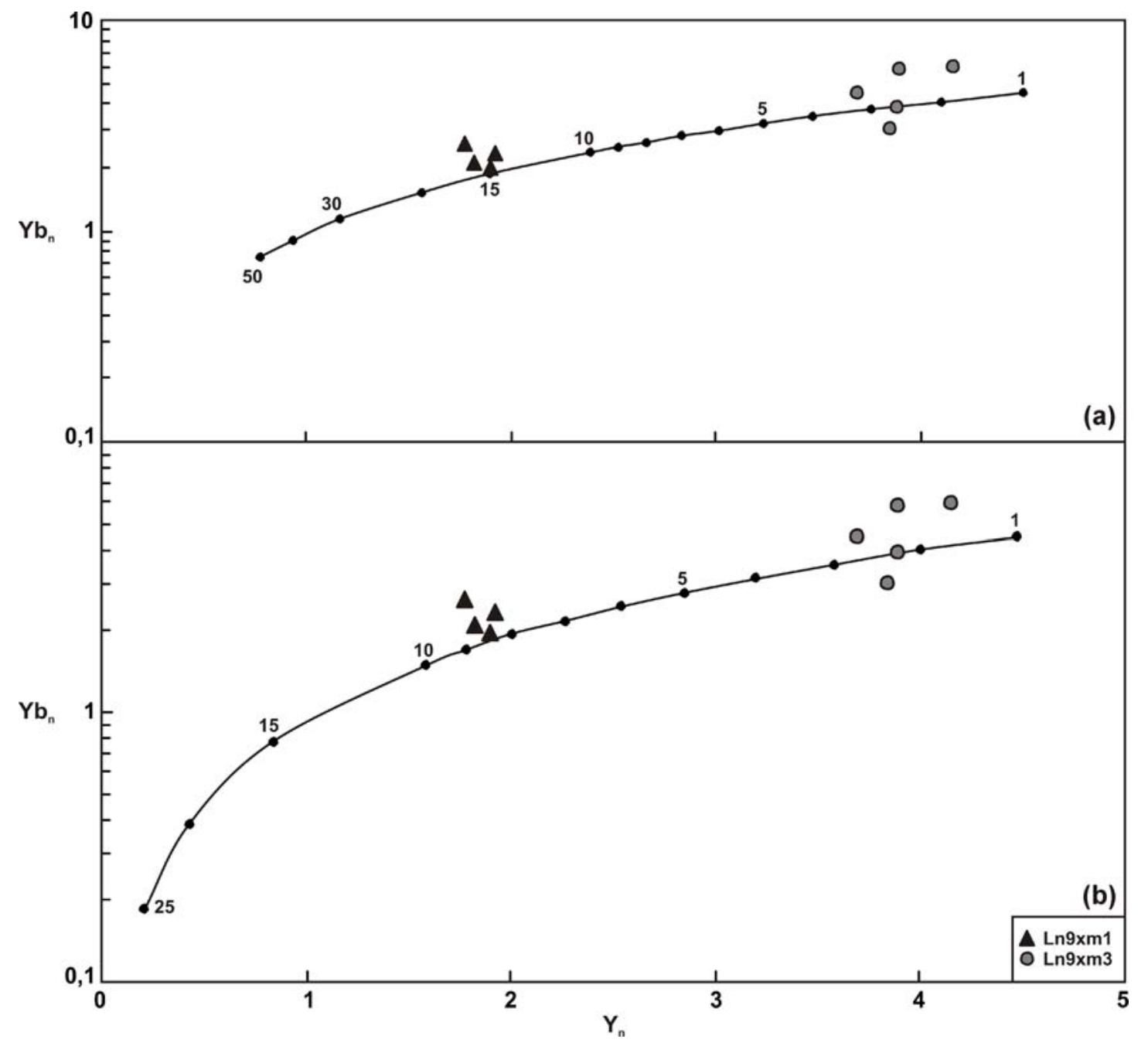

Figura 30: Curvas geradas por modelamentos por fusão em equilíbrio (a) e fusão fracionada (b) por meio de equações de Norman et al. (1998).

Os padrões de elementos incompatíveis dos xenólitos (Figura 31) foram comparados com os padrões previstos por 1 a $12 \%$ de fusão em equilíbrio e $1 \%, 3 \%$ e $5 \%$ de fusão fracionada do manto primitivo. Todos os xenólitos apresentaram padrões distintos aos previstos pelos modelamentos. Anomalias negativas de $\mathrm{Ti}$ e fracionamento de $\mathrm{Zr}$ e Hf em relação aos ETR são observados em todos os xenólitos, sendo mais acentuadas no Ln9xm2. Anomalia negativa de $\mathrm{Nb}$, prevista pelos modelos, é observada no xenólito Ln9xm1. No xenólito Ln9xm2, a ausência da anomalia positiva de Nb é esperada, já que a composição deste diopsídio reflete processos de metassomatismo. Esta mesma anomalia é muito fraca ou inexistente no xenólito Ln9xm3. Nesse caso, os teores de Nb são baixos (0,6 a 0,8 ppm) muito próximos aos do manto primitivo $(0,9$ a 1,1 vezes o manto primitivo) e não parecem estar relacionados a metassomatismo. A composição deste clinopiroxênio pode ser resultado de menos de $1 \%$ de 
fusão parcial. O padrão de ETRP (Gd-Lu) dos clinopiroxênios deste xenólito e de Ln9xm1 coincidem com os padrões previstos.

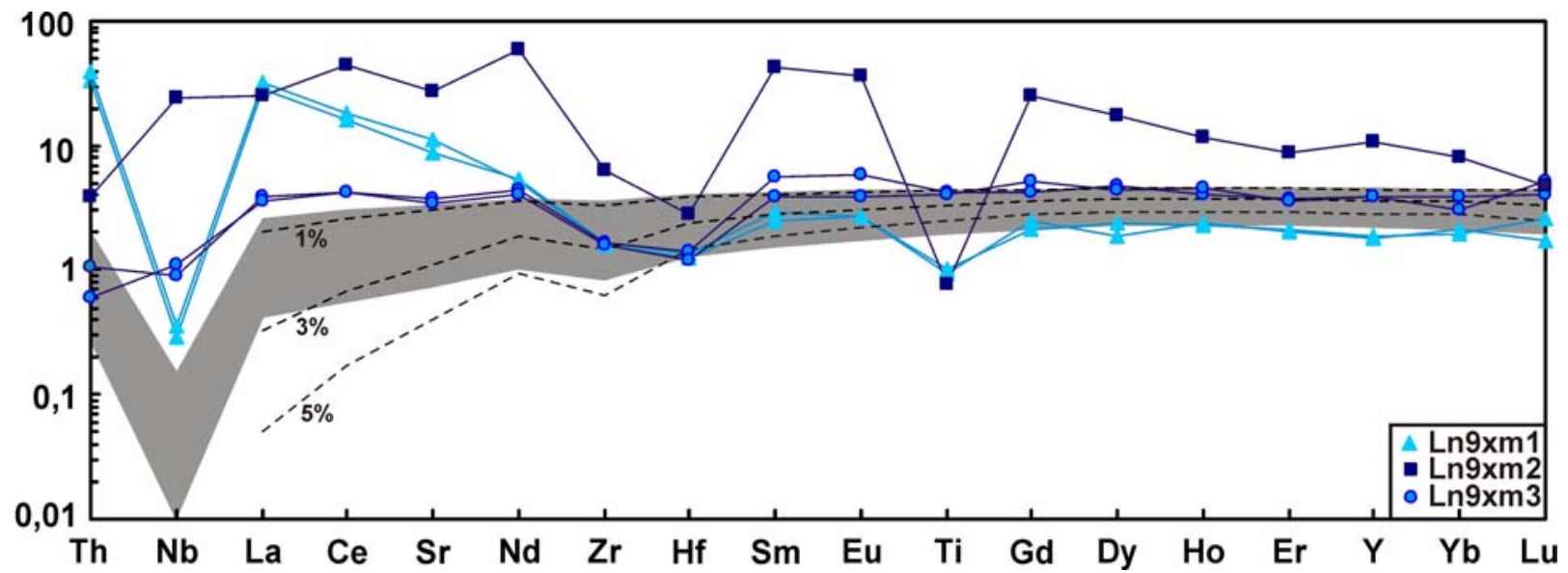

Figura 31: Padrões de elementos incompatíveis normalizados pelo manto primitivo ( $3 x$ condrito C1 de Anders \& Grevesse, 1989) comparados com os padrões previstos por 1 a 12\% de fusão em equilíbrio (região cinza) e 1, 3 e 5\% de fusão fracionada (linhas tracejadas).

\subsection{Discussão}

Trabalhos sobre xenólitos de espinélio peridotitos de várias partes do mundo utilizam informações petrográficas e químicas como índices de empobrecimento de componentes basálticos (e.g. $\mathrm{Al}_{2} \mathrm{O}_{3}, \mathrm{Na}_{2} \mathrm{O}$ ) por fusão parcial, e também refertilização de elementos incompatíveis (LILE, HFS) por introdução/reação de fluidos/fundidos com peridotitos mais empobrecidos resultando no chamado decoupling entre os componentes basálticos e os elementos altamente incompatíveis (e.g. Comin-Chiaramonti et al., 1986). Em geral, uma baixa proporção modal de clinopiroxênio, maiores $\mathrm{C}$ \# de espinélio, maiores $\mathrm{Mg} \#$ das fases silicáticas e menores teores de $\mathrm{Al}_{2} \mathrm{O}_{3}$ e $\mathrm{Na}_{2} \mathrm{O}$ dos piroxênios são alguns dos principais índices relacionados com peridotitos mais empobrecidos (e.g.; Beard et al., 2007; Grégoire et al., 2005; Pearson et al., 2003; Kubo, 2002; Fodor et al., 2002; Hellebrand et al., 2001).

A termometria mostrou que os xenólitos de Ubatuba representam fragmentos de manto com temperatura ( $\mathrm{T}_{\text {Wells }}$ ) variando de 810 a $900^{\circ} \mathrm{C}$.

A Tabela 5 apresenta um quadro comparativo entre os xenólitos estudados. As informações mostram que os xenólitos de espinélio Iherzolito Ln9xm3 e Ln9h podem representar fragmentos de manto fértil pouco afetados por fusão parcial e refertilização, haja visto os modelamentos feitos através da química mineral de elementos traços ( 2 a $3 \%$ de fusão fracionada ou em equilíbrio), altos teores de $\mathrm{Al}_{2} \mathrm{O}_{3}$ em ortopiroxênio, altos teores de $\mathrm{Al}_{2} \mathrm{O}_{3} \mathrm{e}$ 
$\mathrm{Na}_{2} \mathrm{O}$ em clinopiroxênio, abundante espinélio com baixo $\mathrm{Cr} \#$, padrões de ETR do clinopiroxênio praticamente planos com enriquecimento 10x o condrito e fases silicáticas com Mg\# menores. Em contraste, espinélio Iherzolito Ln9xm1 tem apenas traços de espinélio, menores teores de $\mathrm{Al}_{2} \mathrm{O}_{3}$ nos piroxênios e olivina com maior concentração de $\mathrm{Cr}$, todos indicativos de seu maior empobrecimento (8 a $9 \%$ de fusão fracionada). Esse último xenólito tem evidências de refertilização por LILE sem participação dos HFS (altas razões LILE/HFS), o que poderia ocorrer devido a um processo de metassomatismo associado a fluxos em zonas de subducção (e.g. Zanetti et al., 1999).

O wehrlito Ln9xm2 apresenta comportamento distinto em relação aos outros xenólitos e dificilmente se encaixa nas correlações feitas pela química dos minerais e tampouco no modelamento de traços, visando uma interpretação relacionada ao empobrecimento por fusão parcial. Os teores de $\mathrm{Al}_{2} \mathrm{O}_{3}$ são baixos, e são maiores no ortopiroxênio que no clinopiroxênio, em contraste com o observado nos outros xenólitos. A olivina mostra o mais baixo $\mathrm{Mg \#} \mathrm{e}$ também não se correlaciona ao maior empobrecimento indicado pelos teores de $\mathrm{Al}_{2} \mathrm{O}_{3}$ dos piroxênios. O clinopiroxênio está em desequilíbrio com os outros minerais e apresenta uma concentração notável de LILE e HFS e padrão de ETR com enriquecimento de ETRL, porém com $\mathrm{La} / \mathrm{Nd}_{\mathrm{N}}<1$, semelhante ao padrão encontrado em clinopiroxênios formados por reação com fundidos alcalinos (Bianchinni et al., 2007). Apesar de existir a possibilidade de terem sido formados pela interação com o lamprófiro encaixante, não apresentam química semelhante aos cristais notadamente formados por essa interação cujos teores de $\mathrm{TiO}_{2}$ e $\mathrm{Al}_{2} \mathrm{O}_{3}$ são, em geral, muito maiores. Por este motivo, a formação dos cristais de clinopiroxênio de Ln9xm2 é atribuída a um processo de metassomatismo mantélico distinto do que atuou em Ln9xm1. 
Tabela 5: Quadro comparativo com as características gerais dos xenólitos de Ubatuba.

\begin{tabular}{|c|c|c|c|}
\hline & Grupo 1 & Grupo 1 & Grupo 2 \\
\hline Xenólitos & Ln9xm3 e Ln9h & Ln9xm1 & Ln9xm2 \\
\hline Classificação & Sp-Iherzolito & Sp-Iherzolito & Wehrlito \\
\hline Textura & protogranular & protogranular & Intercresc. ol/cpx \\
\hline Sp & Abundante & Traço & $(-)$ \\
\hline Mg\# ol & $89-90$ & 91 & $88-89$ \\
\hline $\mathrm{Cr}$ ol & até 8 ppm & até 25 ppm & até 22 ppm \\
\hline $\mathrm{Ni}$ ol & até 3300 ppm & até 3300 ppm & até 2500 ppm \\
\hline Mg\# opx & $89,6-90,3$ & $90,4-90,6$ & 89,7 \\
\hline $\mathrm{Al}_{2} \mathrm{O}_{3}$ opx & $4,5-4,9 \%$ & $3,6-4,4 \%$ & $2,4 \%$ \\
\hline $\mathrm{TiO}_{2}$ opx & $0,08-0,2 \%$ & $0-0,09 \%$ & $(-)$ \\
\hline Mg\# cpx & $90,2-91,3$ & 91,6 & 91,4 \\
\hline $\mathrm{Al}_{2} \mathrm{O}_{3} \mathrm{cpx}$ & $6,2-7,6 \%$ & $4,4 \%$ & $1,5 \%$ \\
\hline $\mathrm{TiO}_{2} \mathrm{cpx}$ & $0,5-0,8 \%$ & $0,2 \%$ & $0,04 \%$ \\
\hline $\mathrm{Na}_{2} \mathrm{O} \mathrm{cpx}$ & $1,6-2,3 \%$ & $1,2 \%$ & $0,6 \%$ \\
\hline $\mathrm{Cr} \# \mathrm{sp}$ & $0,07-0,1$ & 0,2 & $(-)$ \\
\hline $\mathrm{Al}_{2} \mathrm{O}_{3} \mathrm{sp}$ & $58-61 \%$ & $49,6 \%$ & $(-)$ \\
\hline ETR cpx & plano,10x condrito & 100x La, plano Gd-Lu & $\begin{array}{l}\text { ETRL convexo; } \\
(\mathrm{La} / \mathrm{Yb})_{\mathrm{N}} \sim 3\end{array}$ \\
\hline$\left(L a_{N} / N b_{N}\right)_{c p x}$ & $3-4,3$ & $89-111$ & 1 \\
\hline$\left(L a_{N} / N d_{N}\right)_{c p x}$ & $0,7-0,9$ & $4-6,3$ & 0,4 \\
\hline$\left(G d_{N} / T i_{N}\right)_{c p x}$ & $1-1,4$ & $2-2,6$ & 32 \\
\hline$\left(\mathrm{Nd}_{N} / \mathrm{Sr}_{\mathrm{N}}\right)_{\mathrm{cpx}}$ & $1-1,2$ & $0,4-0,7$ & 2 \\
\hline$\left(\mathrm{Sm}_{\mathrm{N}} / \mathrm{Zr}_{\mathrm{N}}\right)_{\mathrm{cpx}}$ & $1,8-3,2$ & $1,5-2$ & 6,3 \\
\hline Fusão em equilíbrio & $2-3 \%$ & $15 \%$ & $(-)$ \\
\hline Fusão fracionada & $2-3 \%$ & $8-9 \%$ & $(-)$ \\
\hline Enriquecimento & $(-)$ & alto LILE/HFS & LILE, HFS \\
\hline
\end{tabular}




\section{XENÓLITOS DO KIMBERLITO LIMEIRA 1 (MONTE CARMELO- MG)}

\subsection{Situação geológica}

O Kimberlito Limeira 1 foi estudado por Meyer \& Svisero (1991), Svisero \& Ulbrich (1992), Bizzi et al. (1994), Gibson et al. (1995), Costa (1996), Costa et al. (1997), Carlson et al. (1996) e Araújo et al. (2001). Encontra-se inserido no contexto da Província Ígnea do Alto Paranaíba, uma das maiores províncias ígneas máficas potássicas do mundo $\left(>15000 \mathrm{~km}^{3}\right.$ de volume) (Gibson et al., 1995). Os corpos ígneos da província encontram-se encaixados em um cinturão móvel Proterozóico (Faixa Brasília), próximo à margem exposta do Cráton São Francisco, e faz parte de um conjunto de províncias ígneas alcalinas Cretáceas localizadas ao redor das margens da Bacia do Paraná (Gibson et al., 1995).

A Província do Alto Paranaíba é composta por rochas de suítes ultrapotássicaspotássicas, ultramáficas-máficas, lavas insaturadas em sílica e intrusões hipoabissais na forma de diques, plugues, diatremas, depósitos piroclásticos e de fluxos de lava e grandes complexos plutônicos (Gibson et al., 1995). As lavas e os tufos, representados pela Formação Mata da Corda (Figura 32), compõem as manifestações mais volumosas de magmatismo máficopotássico na província. As intrusões e pipes afloram predominantemente próximo às regiões de Coromandel (Figura 32) e Bambuí, onde ocorrem corpos como os de Bocaina, Córrego do Couro, Morro Alto, Córrego Varjão, Indaiá 1 e 2, Limeira 1 e 2, Mata do Lenço, Pântano, Serra do Bueno e Três Ranchos, além de pipes muito alterados (e.g. Boa Esperança, Cana Verde e Japecanga) (Gibson et al., 1995) (Figura 32). Xenólitos de espinélio Iherzolitos, dunitos, harzburgitos e glimmeritos ocorrem na maior parte das ocorrências. Xenólitos de granada Iherzolito são raros, porém ocorrem na intrusão Três Ranchos (Gibson et al., 1995).

As lavas e intrusões hipoabissais da província estão espacialmente e temporalmente associadas com grandes complexos plutônicos com corpos carbonatíticos como os complexos de Araxá (Barreiro), Catalão 1 e 2, Salitre 1 e 2, Serra Negra e Tapira (Figura 32). Segundo Gibson et al. (1995) as rochas da província mostram evidências de uma fonte mantélica heterogênea. As idades modelo ( $T_{\mathrm{DM}}$ de $\mathrm{Nd}$ ) de cerca de $900 \mathrm{Ma}$ sugerem que os magmas são derivados de remobilização do manto litosférico subcontinental previamente enriquecido por pequenas frações de fundidos ricos em K desde o final do Proterozóico (Gibson et al., 1995). Concentrados de mica de kimberlitos, olivina lamproitos, kamafugitos e dos complexos plutônicos mostram idades K-Ar de cerca de 85 Ma (Gibson et al., 1995). Nessa época (85 Ma), segundo Gibson et al. (1995), a região do Alto Paranaíba coincidia com a presente posição da pluma de Trindade ou Martin Vaz. 


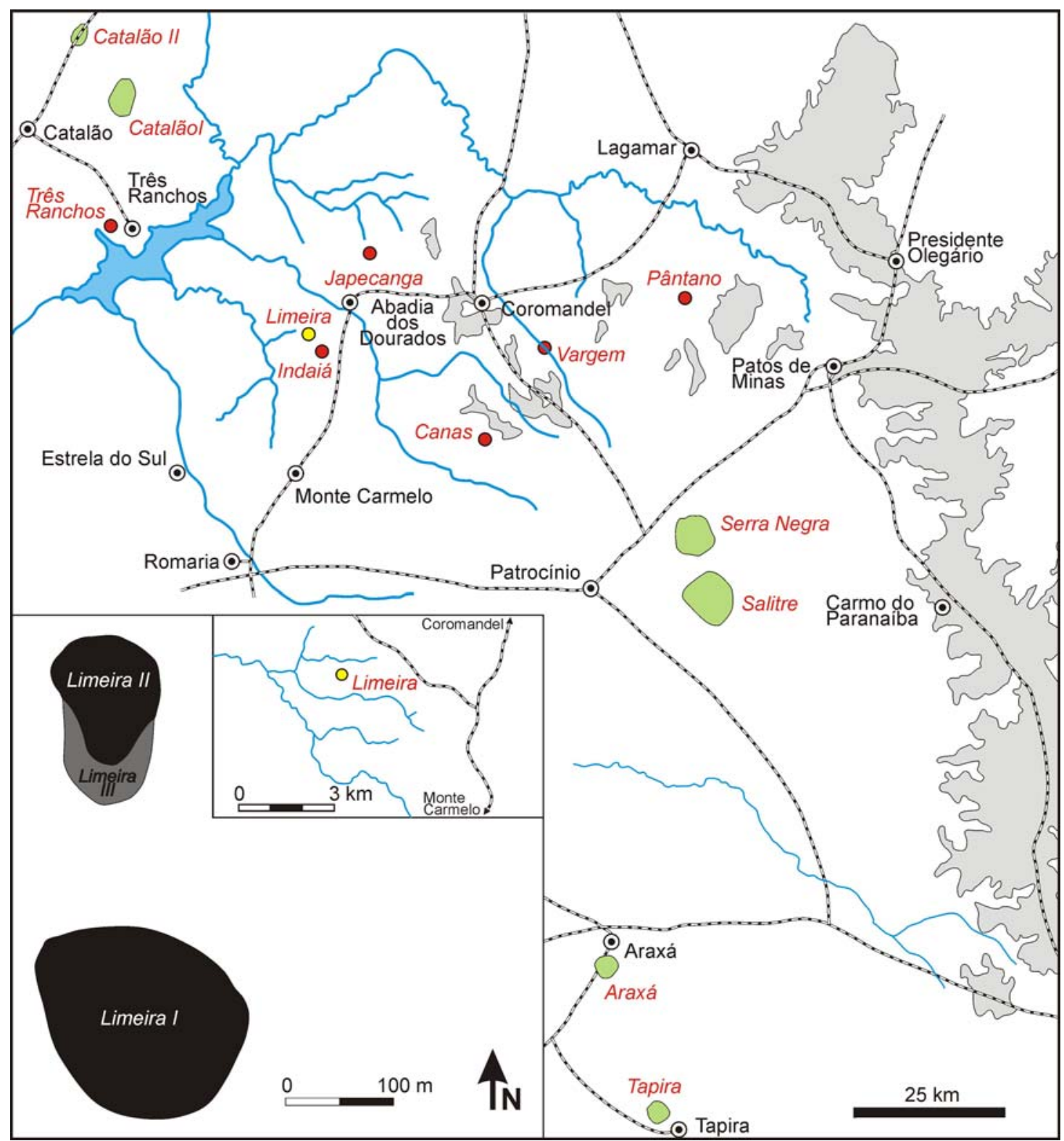

Figura 32: Localização geográfica do Kimberlito Limeira 1 e sua relação com as outras intrusões (em vermelho), complexos carbonatíticos (em verde) e a Formação Mata da Corda (em cinza) no Alto Paranaíba. Na parte inferior à esquerda encontra-se mapa com a dimensão e forma do corpo. Modificado de Meyer \& Svisero (1991).

A maioria dos xenólitos mantélicos da província parecem ter se originado de profundidades relativamente rasas (espinélio Iherzolitos, dunitos), o que levou Bizzi et al. (1994) e Meyer et al. (1994) a propor que alguns magmas da província poderiam ter origem rasa. No entanto, a pressão e temperatura, relativas ao campo de estabilidade do diamante, estimadas para xenólitos da intrusão Três Ranchos, indicam que pelo menos parte dos magmas foram originados de uma fonte profunda ( 150 km) (Gibson et al., 1995).

O Kimberlito Limeira 1, localizado $26 \mathrm{~km}$ a norte da cidade de Monte Carmelo (MG) (Figura 32), apresenta formato piriforme com diâmetro principal de 200 m na direção NW-SE, e 
é intrusivo em granito cataclasado do Grupo Araxá (Svisero \& Ulbrich, 1992) (Figura 32). A rocha kimberlítica é cinza escura com textura inequigranular bem destacada, sendo constituída por macro e microfenocristais de olivina dispersos em uma matriz constituída por monticellita, espinélio, ilmenita, perovskita, calcita, serpentina e apatita (Svisero \& Ulbrich, 1992). Macrocristais de flogopita, ilmenita e cromita também ocorrem subordinadamente (Svisero \& Ulbrich, 1992).

A mineralogia e a textura da rocha indicam que se trata de um kimberlito tipo I de fácies hipoabissal (Meyer \& Svisero, 1991; Svisero \& Ulbrich, 1992); no entanto, segundo Meyer \& Svisero (1991) as rochas diferem isotopicamente dos kimberlitos tipo I e tipo II. Xenólitos do manto com até $15 \mathrm{~cm}$ com composição de dunito, harzburgito e espinélio Iherzolito são relativamente abundantes (Svisero \& Ulbrich, 1992) e em parte portadores de flogopita (Meyer \& Svisero, 1987). Temperaturas de 750 a $850^{\circ} \mathrm{C}$ e pressão de 20 kbar são atribuídas aos xenólitos do Limeira 1 e Indaiá 1 (Meyer \& Svisero,1991). Evidências de substituição mineral e metassomatismo modal similar ao registrado por xenólitos presentes em kimberlitos da África do Sul são descritos nos xenólitos do kimberlito Limeira 1 (Meyer \& Svisero,1991).

\subsection{Petrografia}

No total foram descritos em detalhe 6 xenólitos com dimensões variando de 2 a $5,5 \mathrm{~cm}$ com formas subangulosas a arredondadas (Klxm2), granulação média a grossa e cores cinza esverdeado a verde amarelado/amarronzado (Figura 33).

A maior parte dos espécimes estudados pertencem à suíte peridotítica-piroxenítica segundo a classificação proposta por Dawson (1980). Os xenólitos Klxm1, Klxm4 e Klxm5 apresentam textura protogranular, enquanto Klxm2 mostra textura transicional entre protogranular e porfiroclástica. Textura porfiroclástica não foi observada em nenhum espécime.

Foram realizadas estimativas modais por contagem de pontos em alguns xenólitos. Os resultados encontram-se na Tabela 6 juntamente com as estimativas visuais dos outros xenólitos. O diagrama de Streckeisen (1976) com a classificação dos xenólitos encontra-se na Figura 34. Os xenólitos Klxm4, Klxm5 e Klxm6 correspondem a dunitos, enquanto Klxm1 e Klxm2 são Iherzolitos, embora estejam próximos aos campos do harzburgito (Klxm1) e dunito (KIxm2). O xenólito Klxm3 é o mais rico em fases metassomáticas e foi classificado como glimmerito.

Ao contrário de Ubatuba, os xenólitos mantélicos de Limeira 1 apresentam maior complexidade textural e mineralógica devido à presença de cristais de flogopita, cromita, ilmenita, barita e titanatos. 

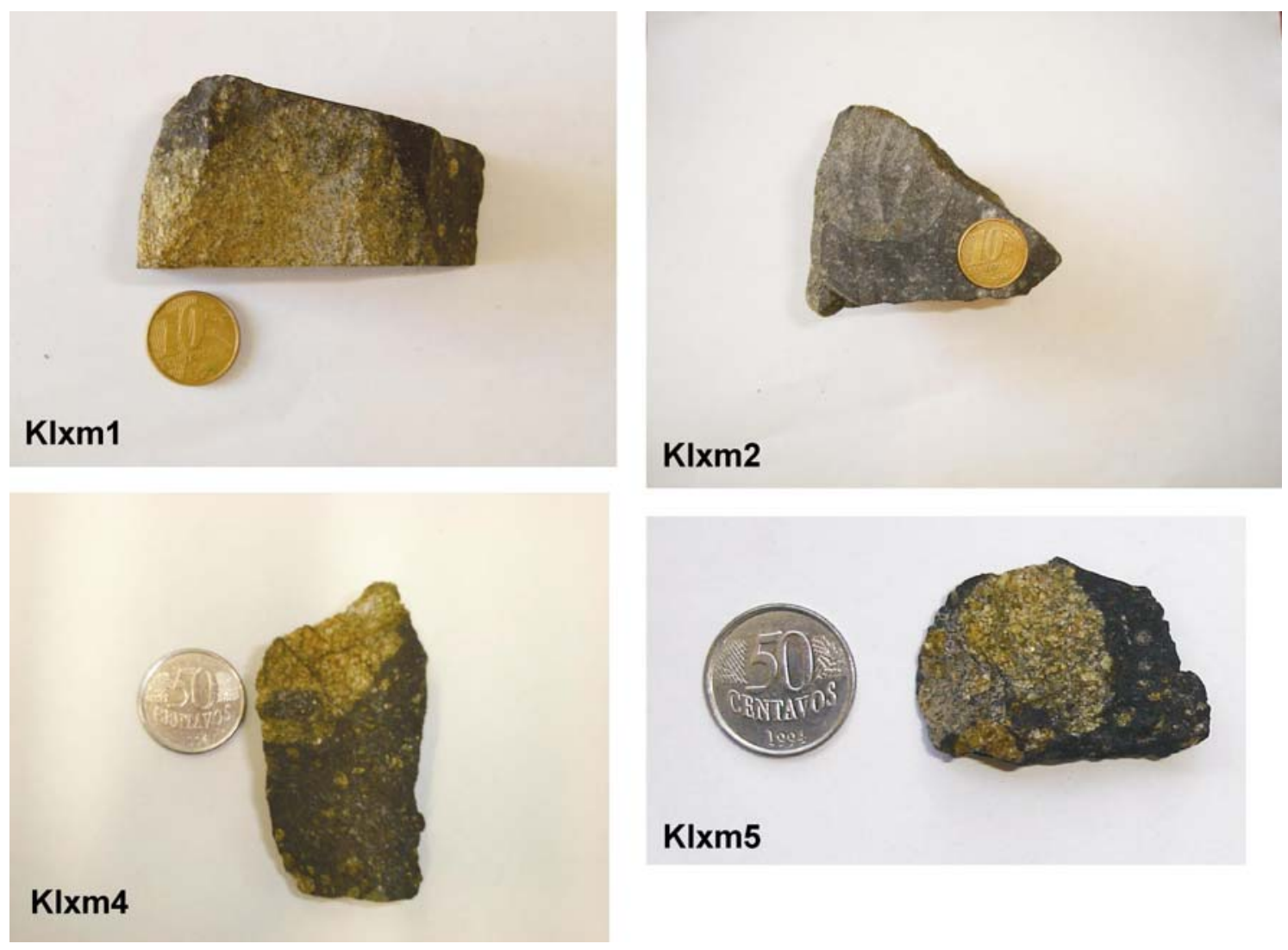

\section{KIxm5}

Figura 33: Exemplos de xenólitos estudado do Kimberlito Limeira1.

Tabela 6: Caracterização geral dos xenólitos de Monte Carmelo.

\begin{tabular}{lllcccccccc}
\hline Xenólito & Dimensão & Textura & Ol & Opx & Cpx & Sp & Phl & Ops & Cb & Classificação \\
\hline KIxm1* $^{*}$ & $6 \mathrm{~cm}$ & Protogranular & 72,4 & 18,4 & 5 & 4,2 & - & - & & Sp Iherzolito \\
KIxm2* $^{*}$ & $3,5 \mathrm{~cm}$ & Transicional & 82,2 & 6,1 & 6,2 & 0,4 & 3,6 & 1,6 & & Sp Iherzolito \\
KIxm3 & $1,5 \mathrm{~cm}$ & Protogranular & 0,5 & - & 27 & & 30 & 40 & 2,5 & glimmerito \\
KIxm4 $^{3}$ & $3 \mathrm{~cm}$ & Protogranular & 81,5 & 1,1 & 2,2 & & 10,9 & 4,3 & & dunito \\
KIxm5* $^{*}$ & $2,5 \mathrm{~cm}$ & Protogranular & 90,6 & 6,8 & 1,5 & 1 & - & 0,1 & & Sp dunito \\
KIxm6 $^{2}$ & $\mathbf{c m}$ & Transicional. & 65 & & & & 25 & 10 & & dunito \\
\hline
\end{tabular}

*estimativa por contagem de pontos. 


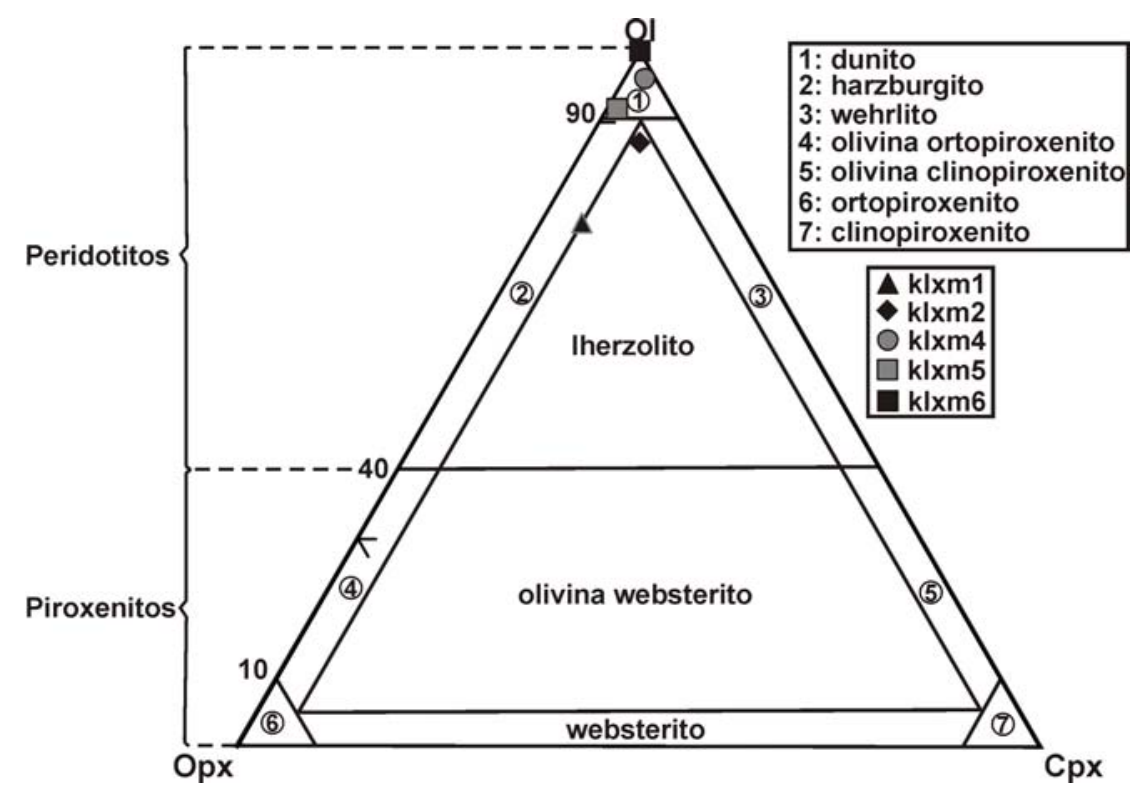

Figura 34: Diagrama de Streckeisen (1976) com a classificação dos xenólitos maiores do Kimberlito Limeira 1.

Os xenólitos estudados foram divididos petrograficamente em três grupos estabelecidos pela presença e crescente proporção de fases metassomáticas. O grupo 1 é o único que não apresenta cristais de flogopita, e tem textura estritamente protogranular. O grupo 2 é mais deformado e mostra flogopita e por vezes fases exóticas como titanatos concentrados em bolsões individualizados. O grupo 3 apresenta xenólitos com predominância de fases metassomáticas (flogopita, ilmenita e priderita) e apenas relíquias de olivina.

\subsubsection{Grupo 1: Espinélio peridotitos com textura protogranular}

\section{Xenólitos KIxm1 e KIxm5}

Os xenólitos desse grupo (Klxm1 e Klxm5) são classificados como espinélio Iherzolito e espinélio dunito, respectivamente. Apesar de mostrarem composições modais diferentes, apresentam características texturais bastante semelhantes e são os únicos xenólitos estudados que não mostram cristais de flogopita e cristais mais expressivos de minerais opacos.

O xenólito Klxm5 tem menor dimensão em relação a Klxm1 (2,5 vs. 5,5 cm). Ambos apresentam textura protogranular com cristais em contatos retos e curvados entre si. A fotomicrografia de KIxm1 encontra-se na Figura 35. 


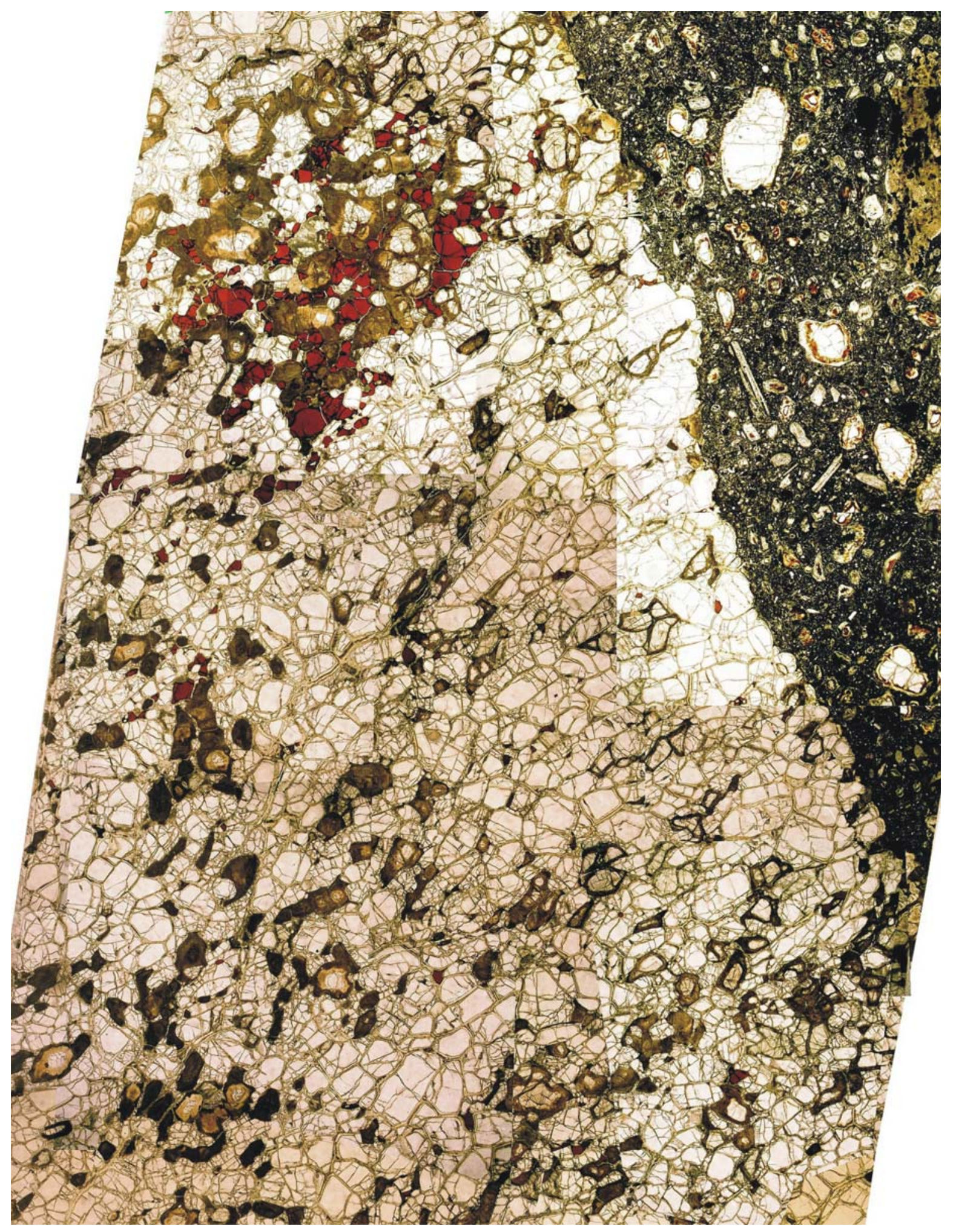

Figura 35: Fotomontagem da lâmina do xenólito KIxm1 a partir de fotomicrografias tiradas com objetiva de 1,25x. Lado maior a montagem: $4 \mathrm{~cm}$. Lado menor da montagem: $2,3 \mathrm{~cm}$. 
O contato entre os xenólitos e o kimberlito apresenta borda de reação com cerca de 0,1 $\mathrm{mm}$ com cor ferruginosa e preta. Em algumas regiões, a borda pode ser um pouco mais espessa $(0,4 \mathrm{~mm})$, com cor cinza amarronzada e minerais opacos pequenos.

Os cristais de olivina desse grupo apresentam dimensões médias de 0,5 a 2,8 mm, com alguns cristais de Klxm5 com $4 \mathrm{~mm}$. No geral os cristais de olivina são anédricos e apresentam por vezes formas alongadas. Cristais com extinção ondulante e bandas de deformação também são observados. As bordas dos cristais bem como as microfraturas estão preenchidas por serpentina esverdeada.

Os cristais de ortopiroxênio apresentam tamanho entre 0,7 e 1,3 mm, em geral menores que os de olivina. Têm cor cinza amarronzado e por vezes finas lamelas de exsolução. Mostram, em sua totalidade, uma borda de alteração fibrosa por vezes com $0,1 \mathrm{~mm}$ de espessura com cor marrom acinzentado e baixa birrefringência (Figura 36). Esse tipo de borda de alteração é restrita aos cristais de ortopiroxênio.

(a)

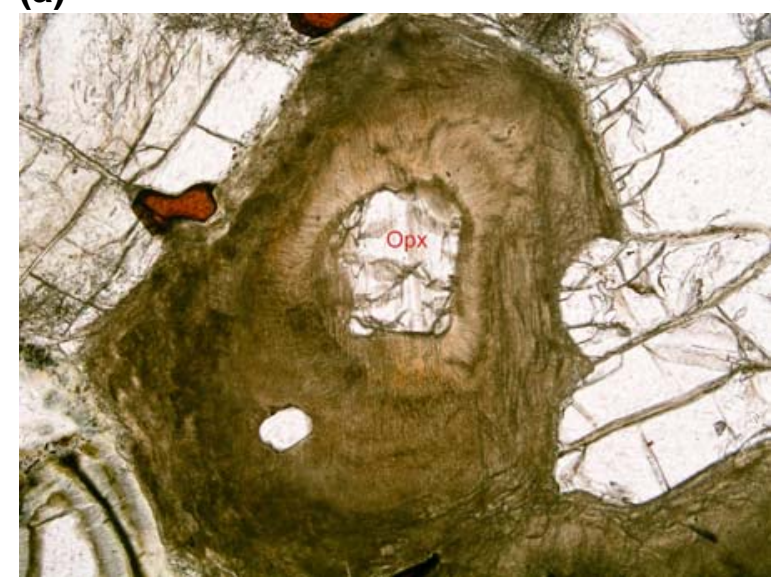

(b)

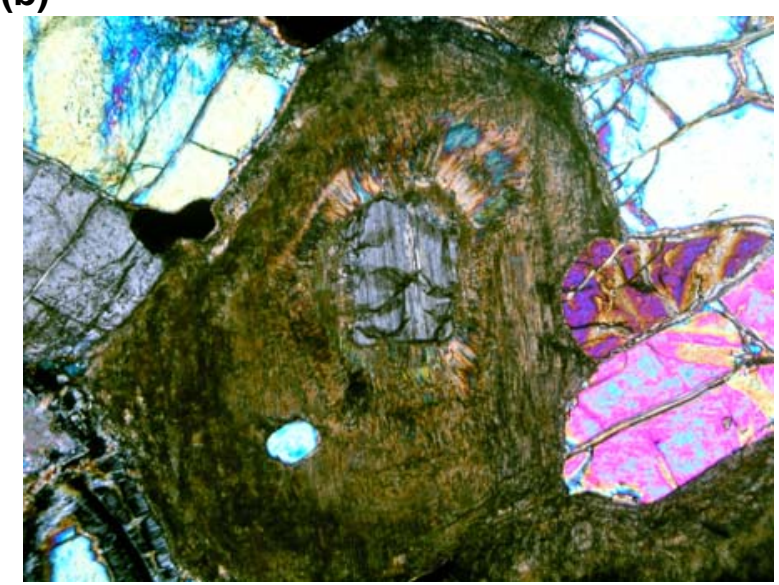

Figura 36: Cristal de ortopiroxênio (Opx) com borda de alteração cor marrom acinzentada e lamelas de exsolução observada com polarizadores cruzados (b). Lado maior da foto: 1,30 mm.

Os cristais de clinopiroxênio são anédricos, com 0,3 a 0,7 mm, por vezes intersticiais e levemente esverdeados (Figura 37). Os contatos entre clinopiroxênio e olivina são no geral curvados, ocorrendo algumas porções onde o contato é reto ou até mesmo levemente irregular. A observação dos contatos entre clino e ortopiroxênio é dificultada pela presença da borda de alteração deste últmo. Trilhas de inclusões fluidas e inclusões de minerais opacos ocorrem em maior concentração no clinopiroxênio próximo à borda dos cristais e planos de clivagem. 


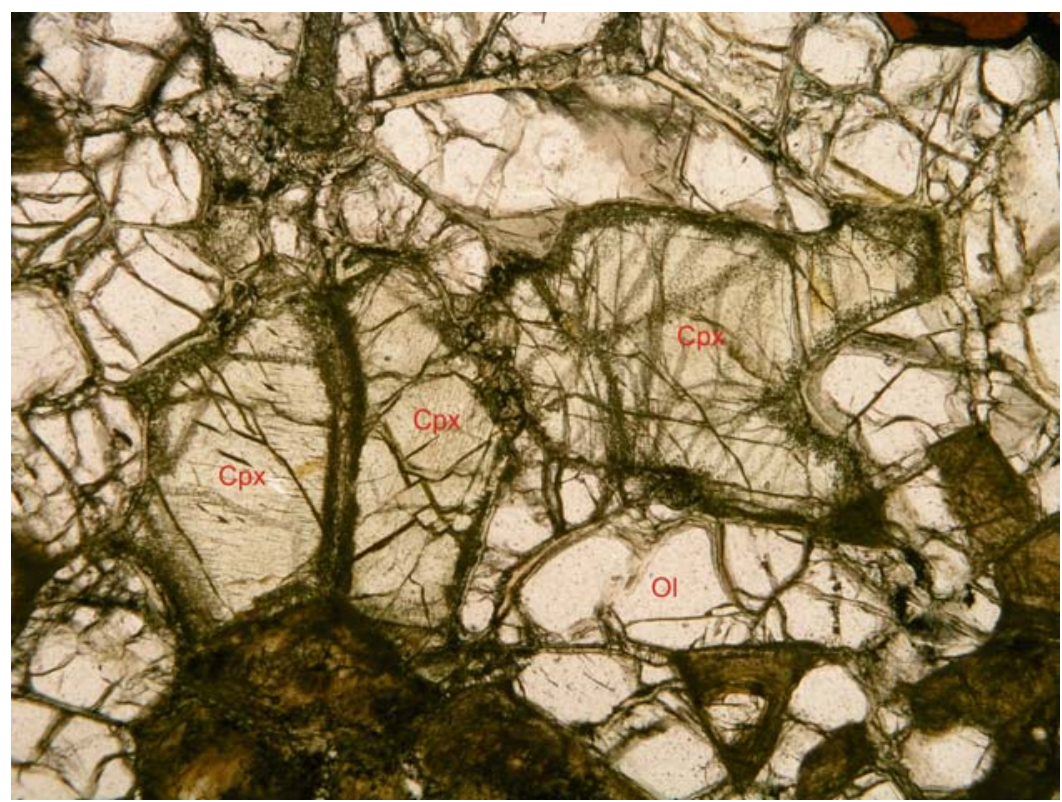

Figura 37: Cristais de clinopiroxênio (Cpx) com concentração de trilhas de inclusões fluidas. Polarizadores paralelos. Lado maior da foto: $2,60 \mathrm{~mm}$.

O espinélio é anédrico e apresenta dimensão entre 0,2 e 1,2 mm. Os cristais têm cor marrom avermelhada e borda muito estreita de cor preta, e geralmente ocupam interstícios. Em Klxm1 estão concentrados em uma região com cerca de $1 \mathrm{~cm}$, associados a ortopiroxênio (em parte pseudomorfoseado) e clinopiroxênio (Figura 38). Essa região forma uma banda com diferente composição mineralógica na amostra, já que fora desta banda são raros os cristais de espinélio (Figura 38). Em Klxm5 parte dos cristais de espinélio também são encontrados associados com piroxênio.

Venulações com até $0,15 \mathrm{~mm}$ de espessura preenchidas por carbonato cortam parte dos xenólitos na região mais próxima ao kimberlito. Cristais muito pequenos de minerais opacos se concentram nas bordas de venulações preenchidas por serpentina.

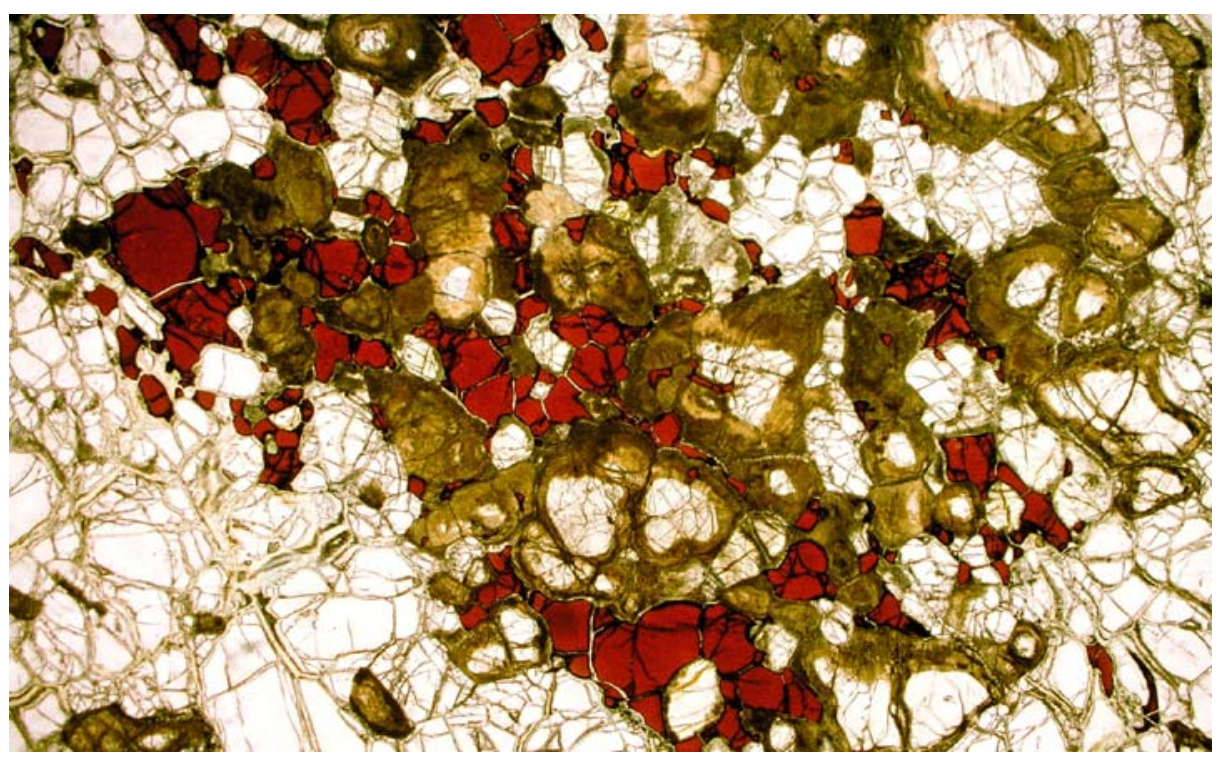

Figura 38: Detalhe na banda com ortopiroxênio (com alteração fibrosa característica), clinopiroxênio e espinélio (cristais com cor marrom avermelhada). Lado maior da foto: 10,4 mm. 


\subsubsection{Grupo 2: Espinélio-flogopita peridotitos com texturas protogranular e transicional}

\section{Xenólito KIxm2}

Este xenólito possui dimensão maior de $3,5 \mathrm{~cm}$, forma arredondada e cor cinza escuro esverdeado. Apresenta composição modal de espinélio-flogopita Iherzolito com ilmenita e mathiasita. No geral a textura pode ser considerada como transicional entre protogranular e porfiroclástica. A fotomicrografia encontra-se na Figura 39.

O xenólito apresenta borda de reação com o kimberlito com 0,1 a 0,3 mm de espessura composta por serpentina e material com cor ferruginosa. Os cristais dos xenólitos localizados na região mais próxima do contato com o kimberlito geralmente apresentam cristais de minerais opacos nas suas bordas e como preenchimento de microfraturas.

Os cristais deste xenólito apresentam maior proporção de microfraturas em relação ao grupo 1.

A olivina está presente na forma de neoblastos pequenos $(0,01$ a $0,02 \mathrm{~mm})$, anédricos, localizados nas bordas dos cristais maiores de olivina e nas suas microfraturas (Figura 40). Esses cristais maiores de olivina apresentam de $\sim 0,4$ a $5,5 \mathrm{~mm}$ e mostram extinção ondulante e bandas de deformação. A clivagem é mais proeminente em relação às dos cristais não deformados e pode aparecer dobrada (Figura 41).

Os contatos entre cristais de olivina são delimitados por venulações preenchidas por serpentina e minerais opacos, que ocupam preferencialmente a borda das venulações. Já os contatos entre olivina e clinopiroxênio são irregulares (ondulados) e assim também o são entre olivina e ortopiroxênio, quando observados.

Em algumas regiões, a olivina apresenta cor cinza esverdeada nas porções próximas aos contatos com clinopiroxênio. Essas mesmas porções também apresentam maior concentração de inclusões fluidas em relação ao restante do cristal. 


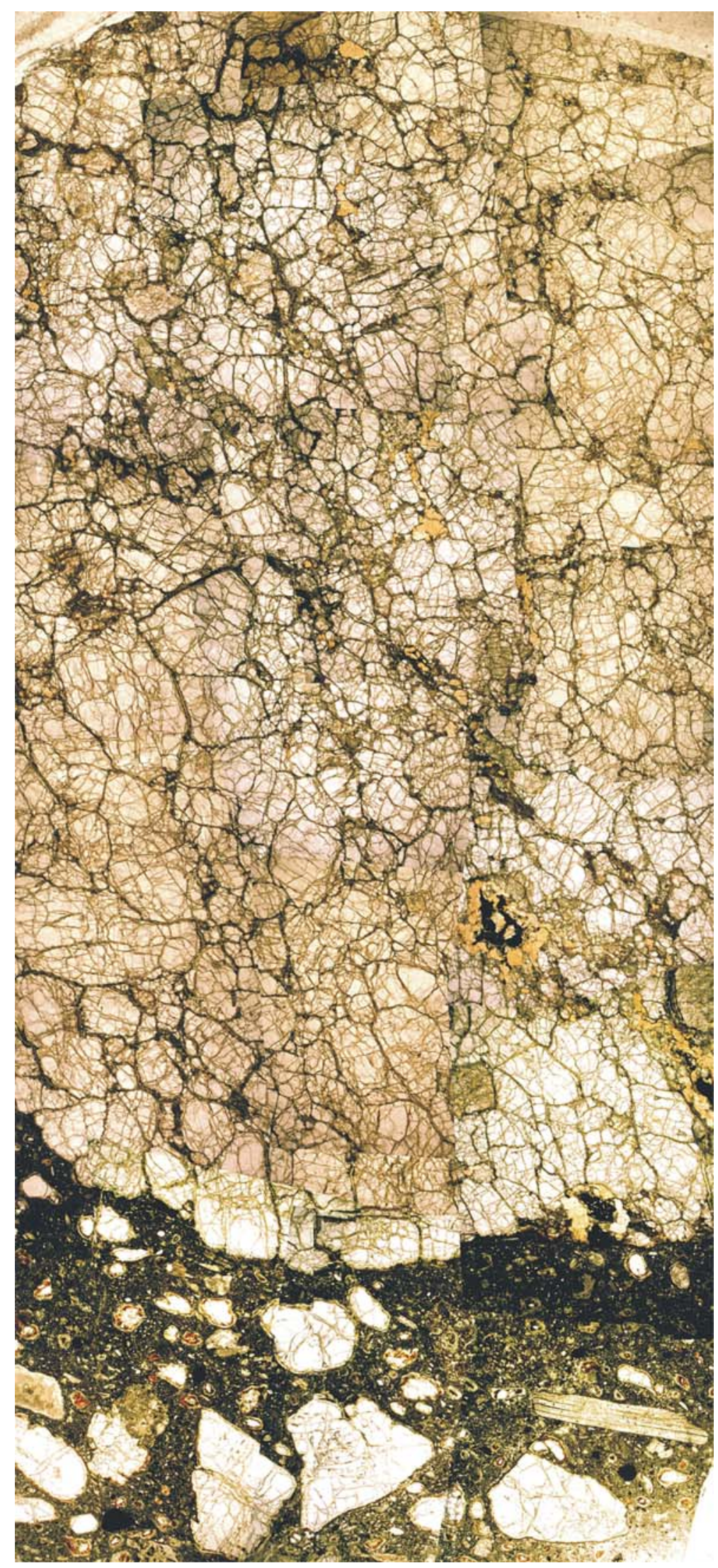

Figura 39: Fotomontagem com a lâmina do xenólito KIxm2 a partir de fotomicrografias tiradas com a objetiva de 1,25x. Lado maior da montagem: 4,5 cm. Lado menor da montagem: $2 \mathrm{~cm}$. 

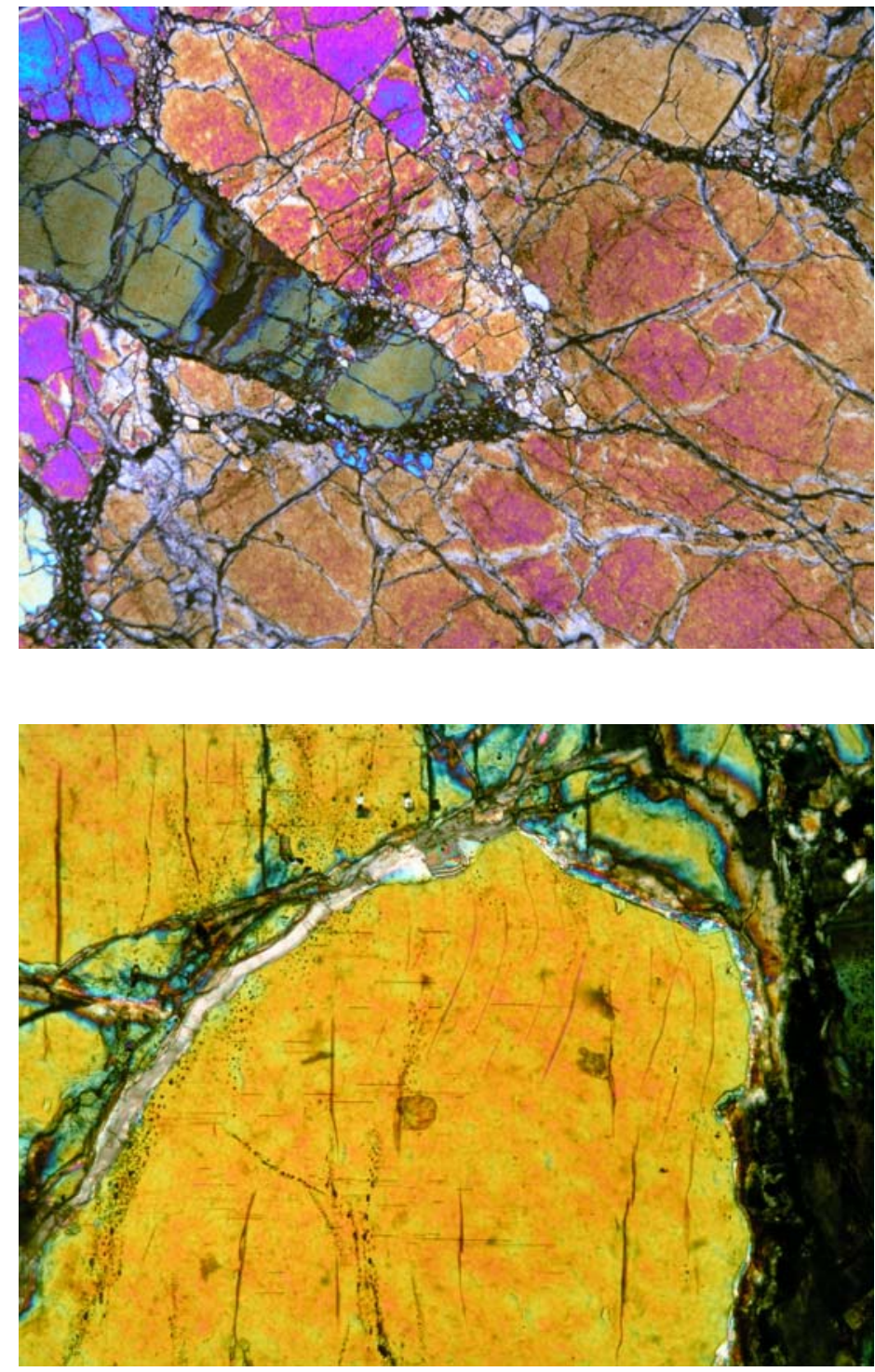

Figura 40: Neoblastos em microfraturas e no limite dos cristais de olivina. Polarizadores cruzados. Lado maior da foto: $2,60 \mathrm{~mm}$.

Figura 41: Clivagem proeminente e dobrada em cristal de olivina. Polarizadores cruzados. Lado maior da foto: $0,65 \mathrm{~mm}$.

Os cristais de ortopiroxênio são anédricos, com 0,5 a $2 \mathrm{~mm}$. Apresentam cor marrom acinzentado com borda de alteração fibrosa com até $0,3 \mathrm{~mm}$ de espessura igual à encontrada nos cristais do grupo 1 e também restrita ao ortopiroxênio (Figura 42). O ortopiroxênio pode ser encontrado em bolsões com concentração de clinopiroxênio, flogopita e minerais opacos, quando não está relacionado a estas regiões pode apresentar bandas de deformação. Cristais anédricos de clinopiroxênio são por vezes encontrados inclusos no ortopiroxênio e em contato irregular com este (Figura 43 e 44). Também ocorrem cristais de ortopiroxênio parcialmente envolvidos e em contato irregular com olivina. 


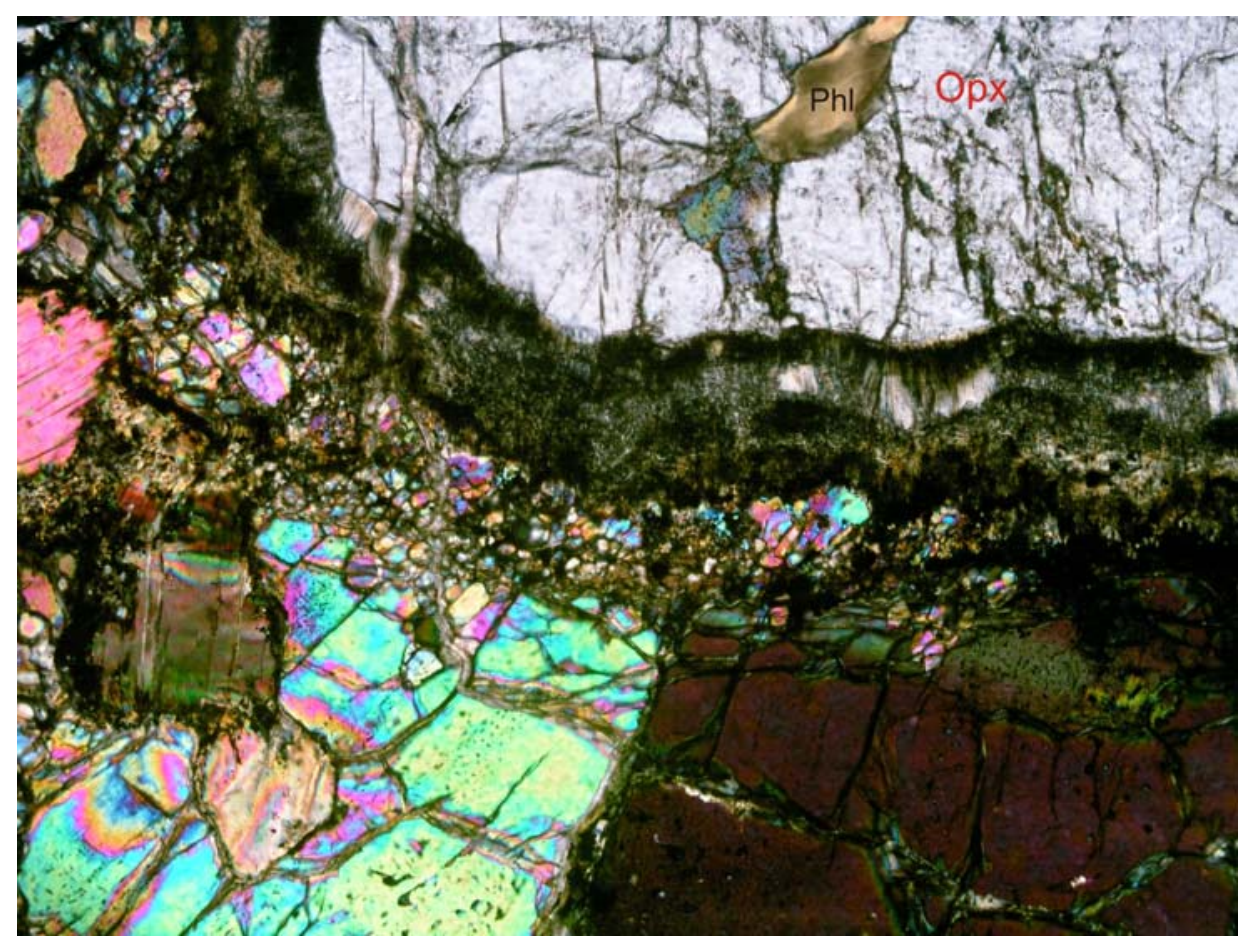

Figura 42: Borda de alteração de cristal de ortopiroxênio (Opx) com cristais fibrosos. Polarizadores cruzados. Lado maior da foto: $1,30 \mathrm{~mm}$.

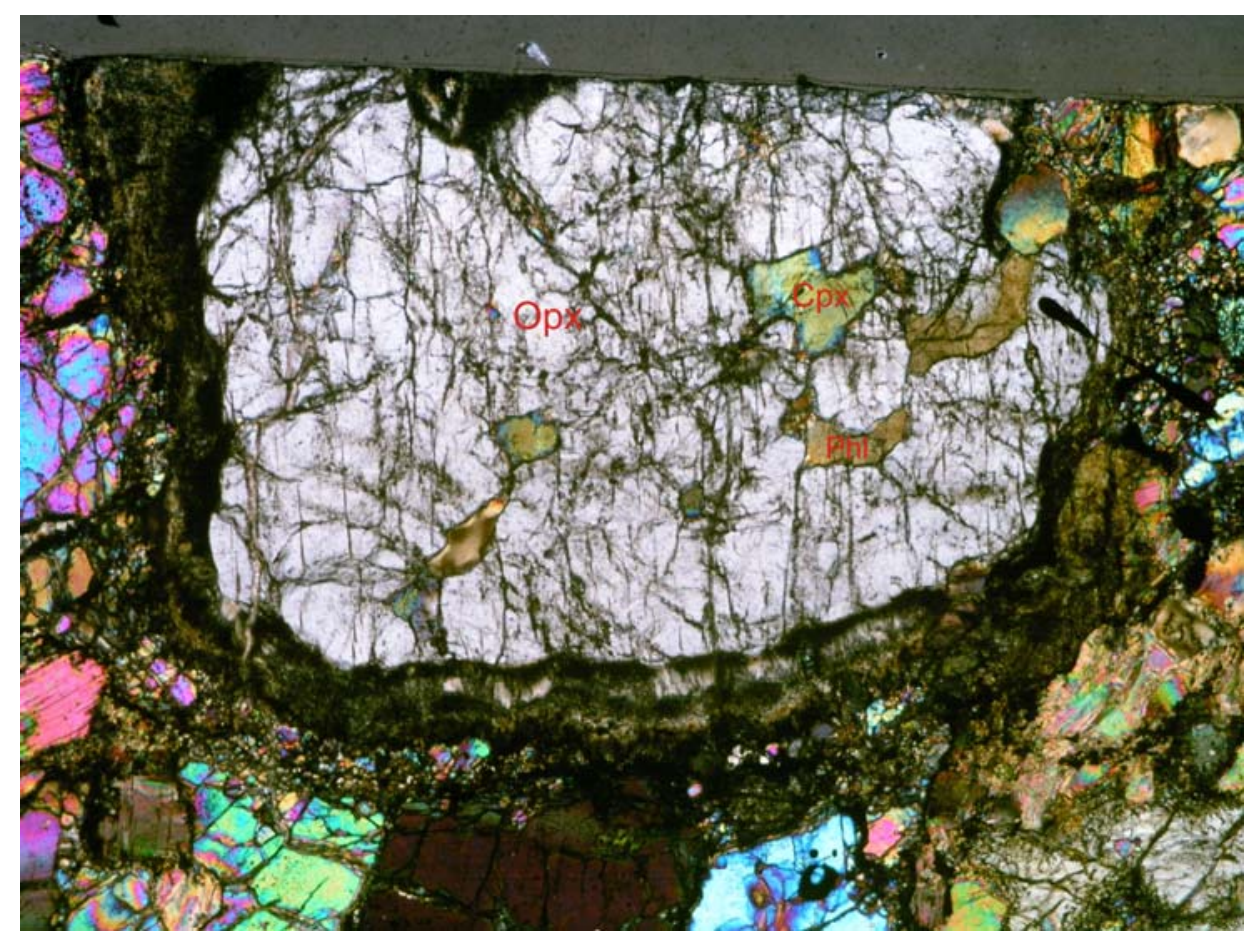

Figura 43: Cristal de ortopiroxênio (Opx) com flogopita (Phl) e clinopiroxênio (Cpx) inclusos. Polarizadores cruzados. Lado maior da foto: $2,60 \mathrm{~mm}$. 

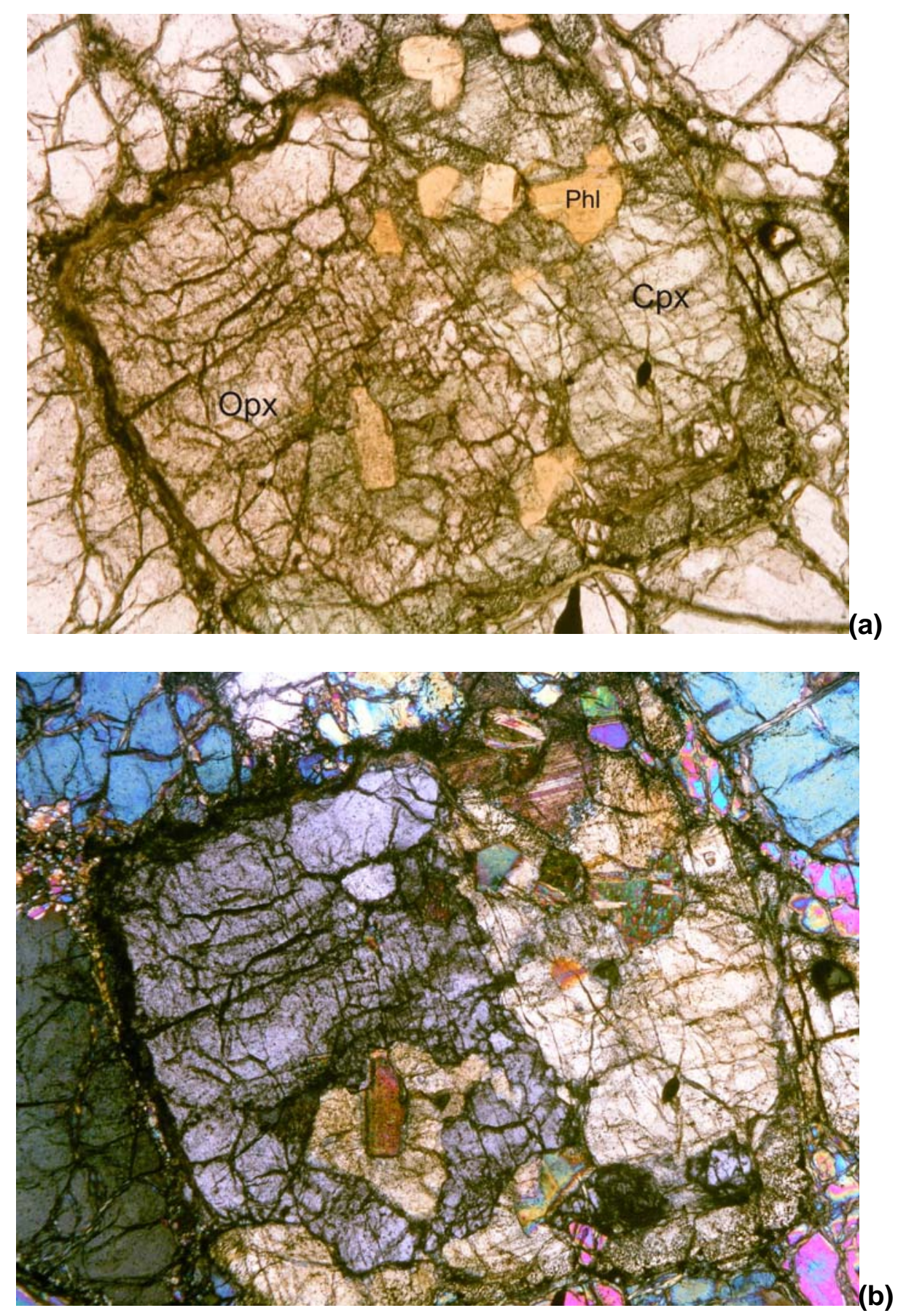

Figura 44: Contato irregular entre ortopiroxênio amarronzado (Opx) e clinopiroxênio esverdeado (Cpx) com inclusões de flogopita (Phl). Polarizadores paralelos (a) e cruzados (b). Lado maior da foto: 2,03 $\mathrm{mm}$.

Os bolsões compreendem regiões de formato irregular com 1,8 a $5,6 \mathrm{~mm}$ de comprimento e apresentam concentração de clinopiroxênio, flogopita e minerais opacos (Figura 45). Na lâmina estudada em detalhe foi possível individualizar 4 bolsões. Todos apresentam zoneamento mineral, sendo compostos da borda para o núcleo por clinopiroxênio, flogopita, clinopiroxênio e minerais opacos (Figura 45). Todos os cristais de clinopiroxênio presentes em cada bolsão apresentam continuidade óptica. 


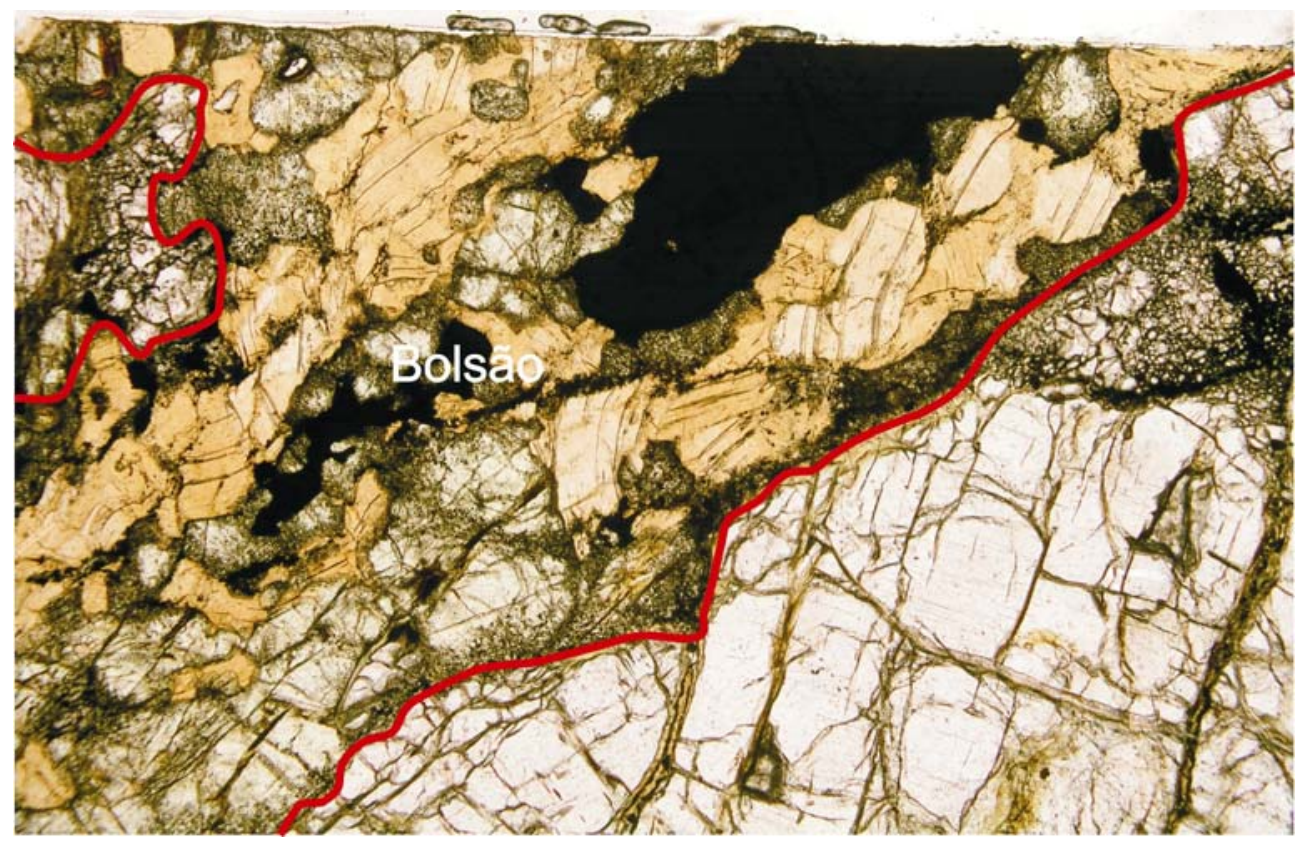

Figura 45: Bolsão zonado com clinopiroxênio, flogopita e minerais opacos. Polarizadores paralelos. Lado maior da foto: $3,25 \mathrm{~mm}$.

Os cristais de clinopiroxênio são anédricos, apresentam dimensões entre 0,5 a 2,5 mm e estão presentes principalmente nos bolsões. No geral contêm concentração de inclusões fluidas distribuídas de preferência nas bordas e em trilhas. Inclusões muito pequenas de material opaco também ocorrem associadas com as inclusões fluidas.

A flogopita é subédrica a anédrica e é freqüentemente encontrada em contato ou como inclusões em clinopiroxênio. Os cristais apresentam pleocroísmo normal que varia de laranja claro a marrom alaranjado. Os cristais presentes nos bolsões têm dimensão entre 0,2 e $1 \mathrm{~mm}$ e são deformados, com extinção ondulante, dobras e kinks (Figura 46). Já pequenos cristais inclusos em olivina e piroxênio apresentam pouca a nenhuma deformação. Os contatos da flogopita com os outros minerais é sempre irregular. Cristais de flogopita próximos ao contato entre xenólito e kimberlito apresentam borda de reação composta por minerais opacos muito pequenos (Figura 47). 


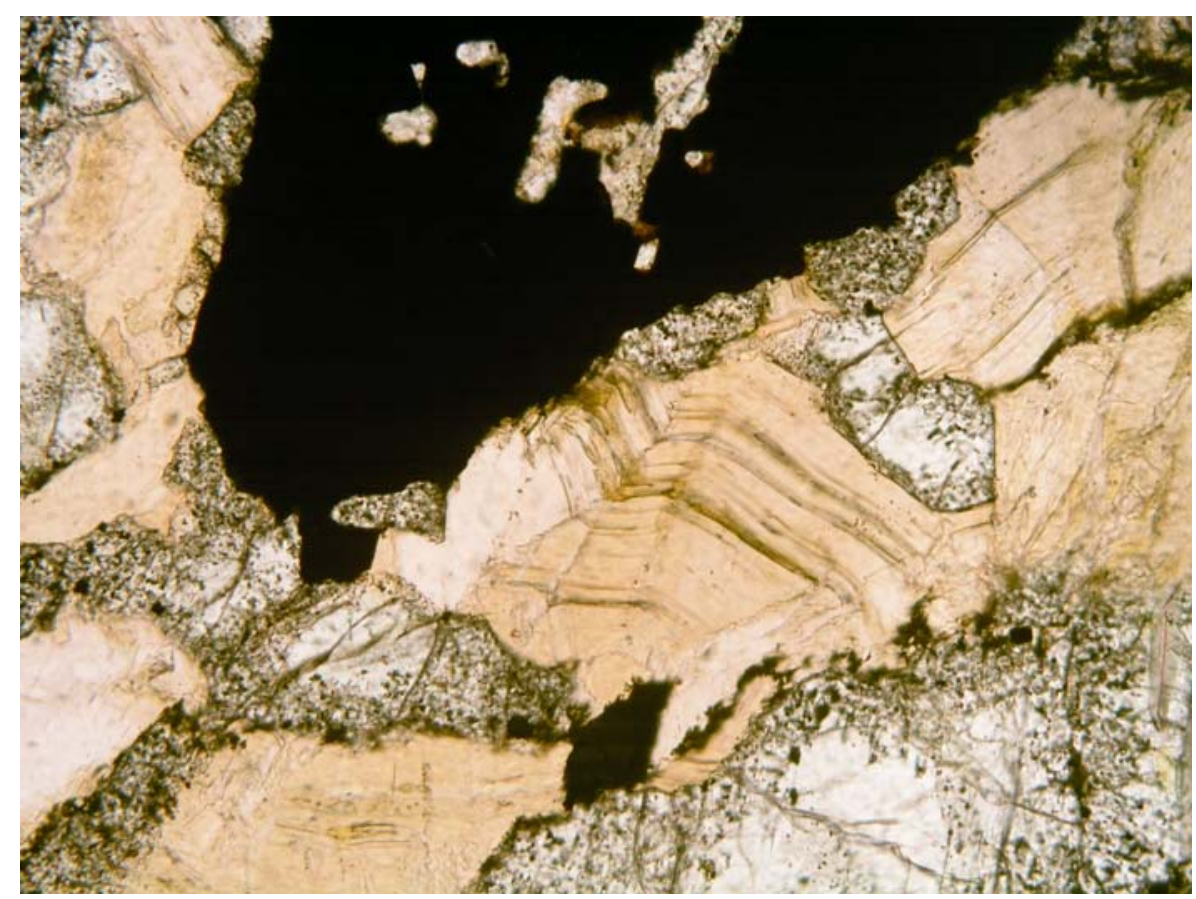

Figura 46: Cristal de flogopita dobrado. Polarizadores paralelos. Lado maior da foto: 0,81 $\mathrm{mm}$.

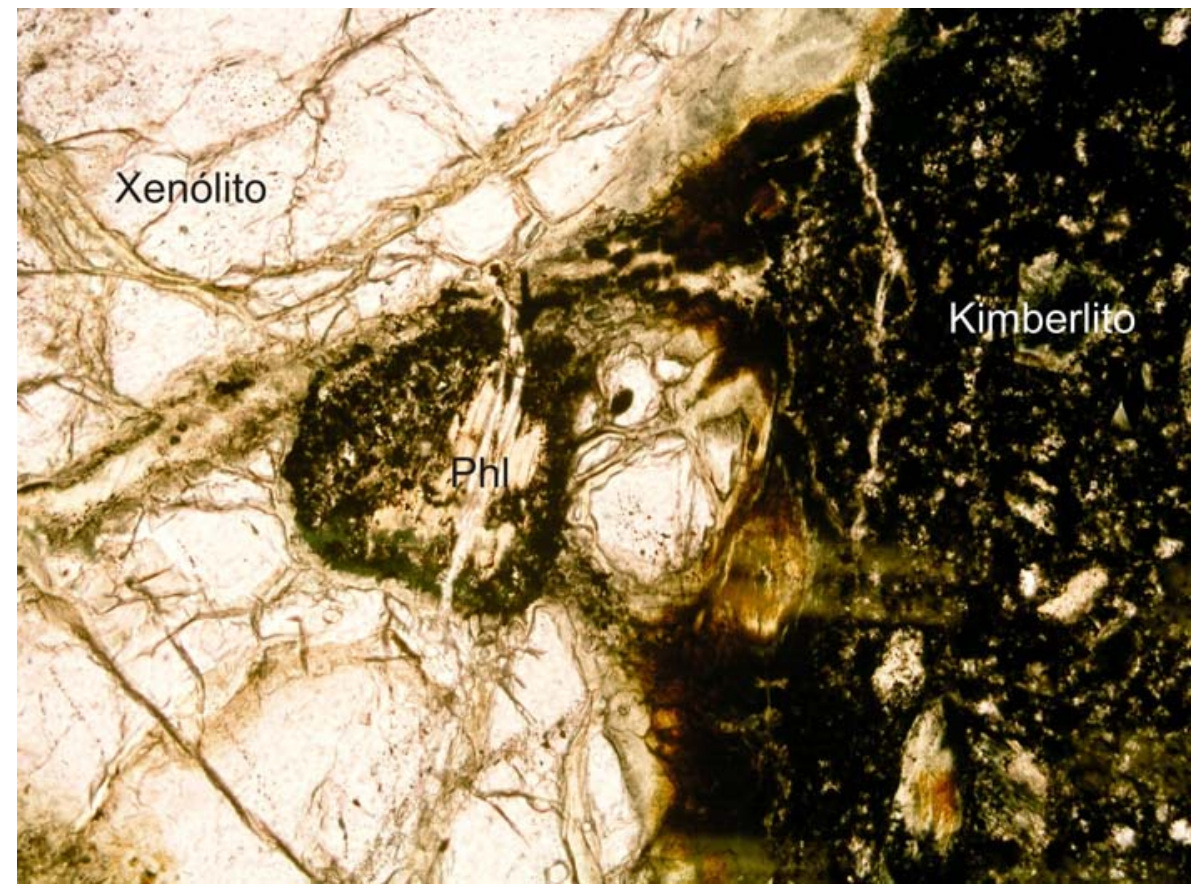

Figura 47: Cristal de flogopita no contato com o kimberlito mostrando borda de reação com minerais opacos pequenos. Polarizadores paralelos. Lado maior da foto: 1,30 mm.

Pequenos cristais de minerais opacos (até $0,05 \mathrm{~mm}$ ) ocorrem em interstícios de neoblastos de olivina e nas bordas de alteração de cristais maiores. Cristais com até $0,5 \mathrm{~mm}$ encontram-se por vezes intercrescidos com flogopita.

Cristais de cromita com 1 a $2 \mathrm{~mm}$ ocorrem próximo ao núcleo dos bolsões. São pretos, anédricos e apresentam contato irregular com clinopiroxênio e flogopita. Esta cromita é sempre manteada por titanato (mathiasita, mineral que será descrito mais adiante). 
Esse xenólito mostra evidências da substituição mineral e metassomatismo modal identificados previamente por Meyer \& Svisero (1991) em xenólitos do kimberlito Limeira 1 e Indaiá 1. A relação entre os minerais é complexa. O clinopiroxênio parece ter substituído tanto olivina como ortopiroxênio (Figura 48), que por sua vez, em algumas porções da lâmina, parece ter substituído a olivina (Figura 49). A flogopita parece ser resultado de reação com todos esses minerais, porém essa reação parece ter ocorrido preferencialmente no clinopiroxênio (Figura 50).

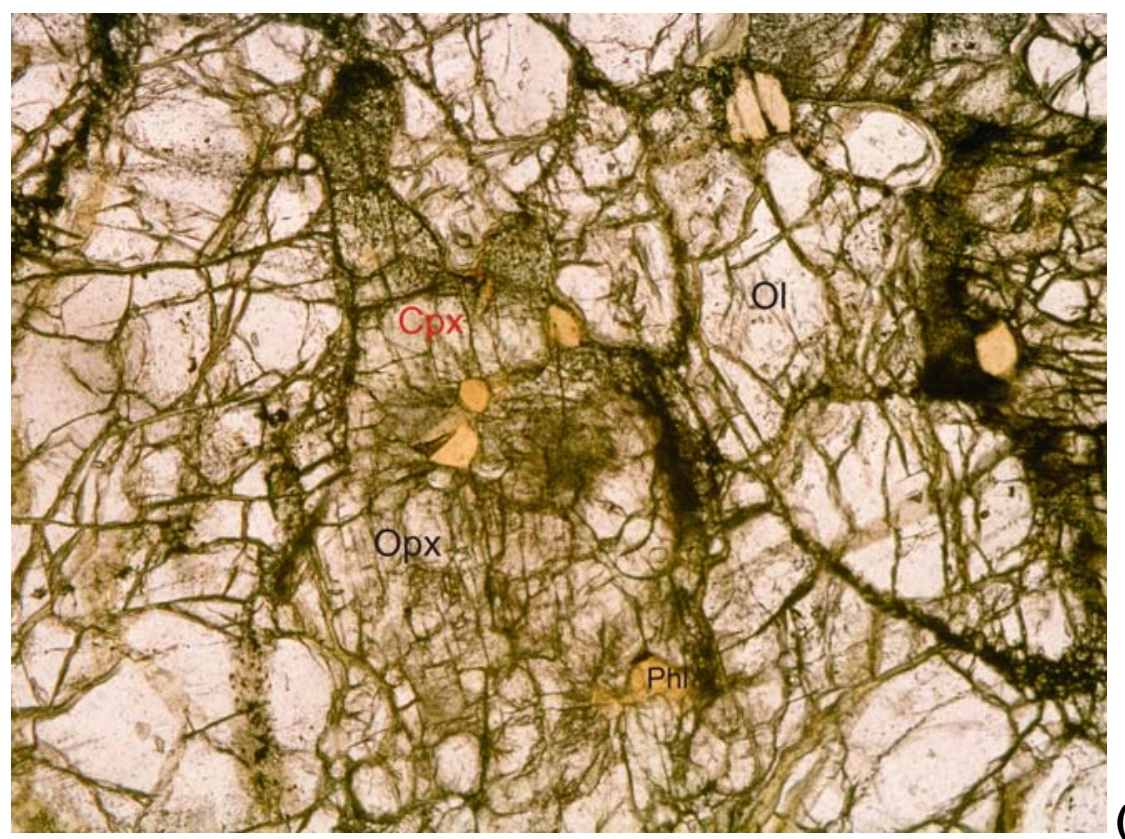

(a)

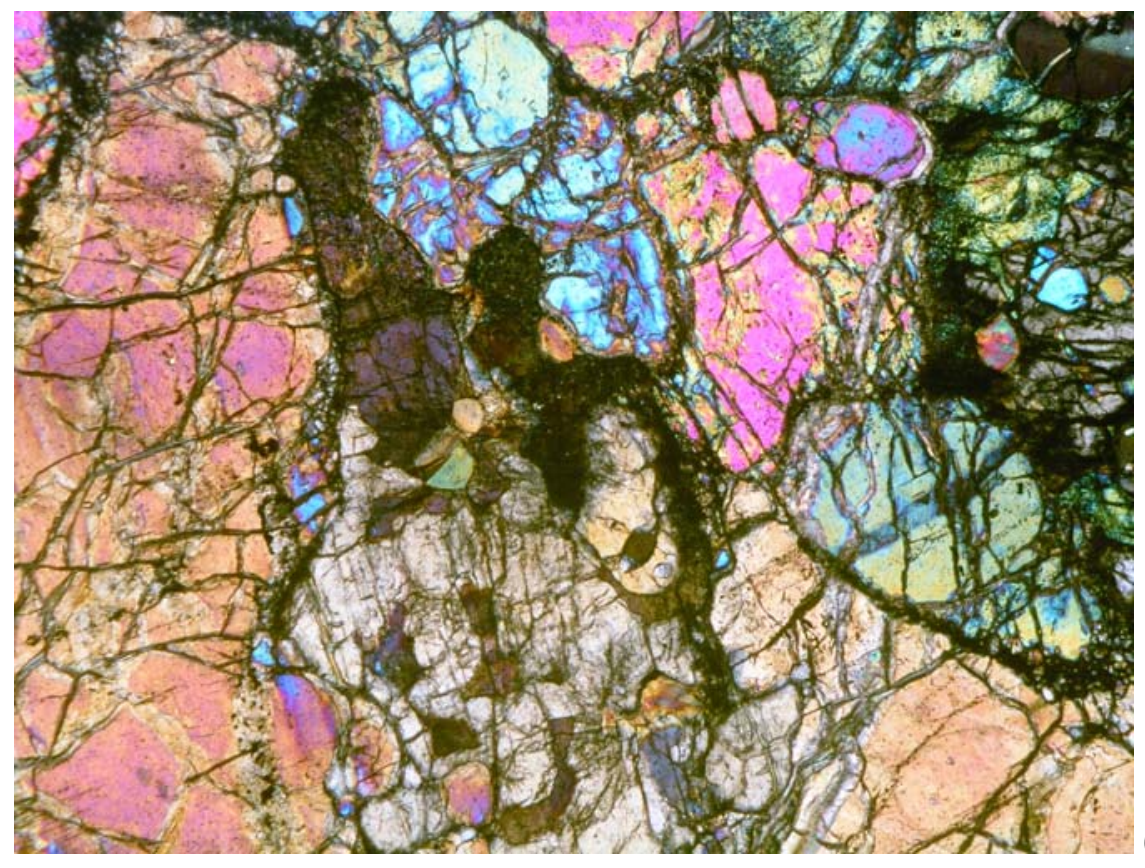

(b)

Figura 48: Relação entre clinopiroxênio (Cpx), ortopiroxênio (Opx) e olivina (OI). Polarizadores paralelos (a) e cruzados (b). Lado maior da foto: $2,03 \mathrm{~mm}$. 


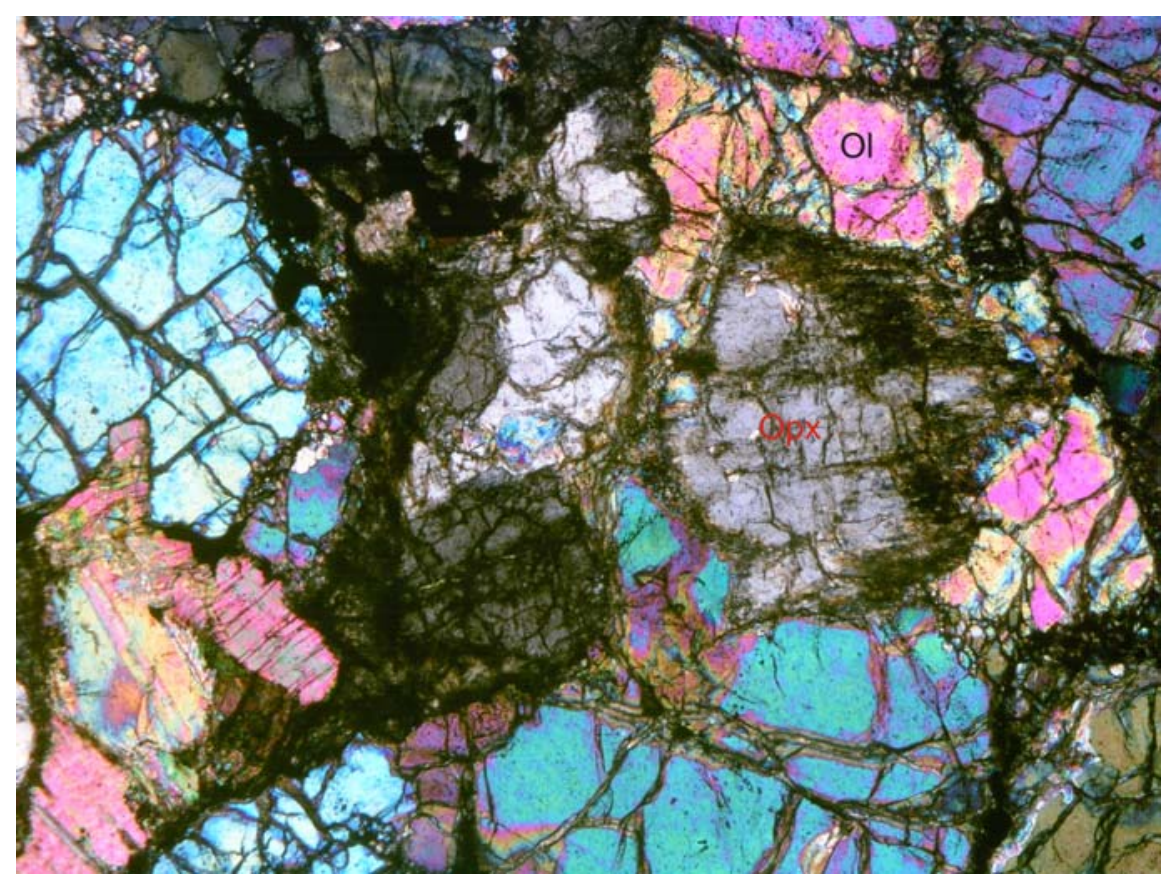

Figura 49: Ortopiroxênio (Opx) em contato com olivina (OI). Nicóis cruzados. Lado maior da foto: $2,03 \mathrm{~mm}$.

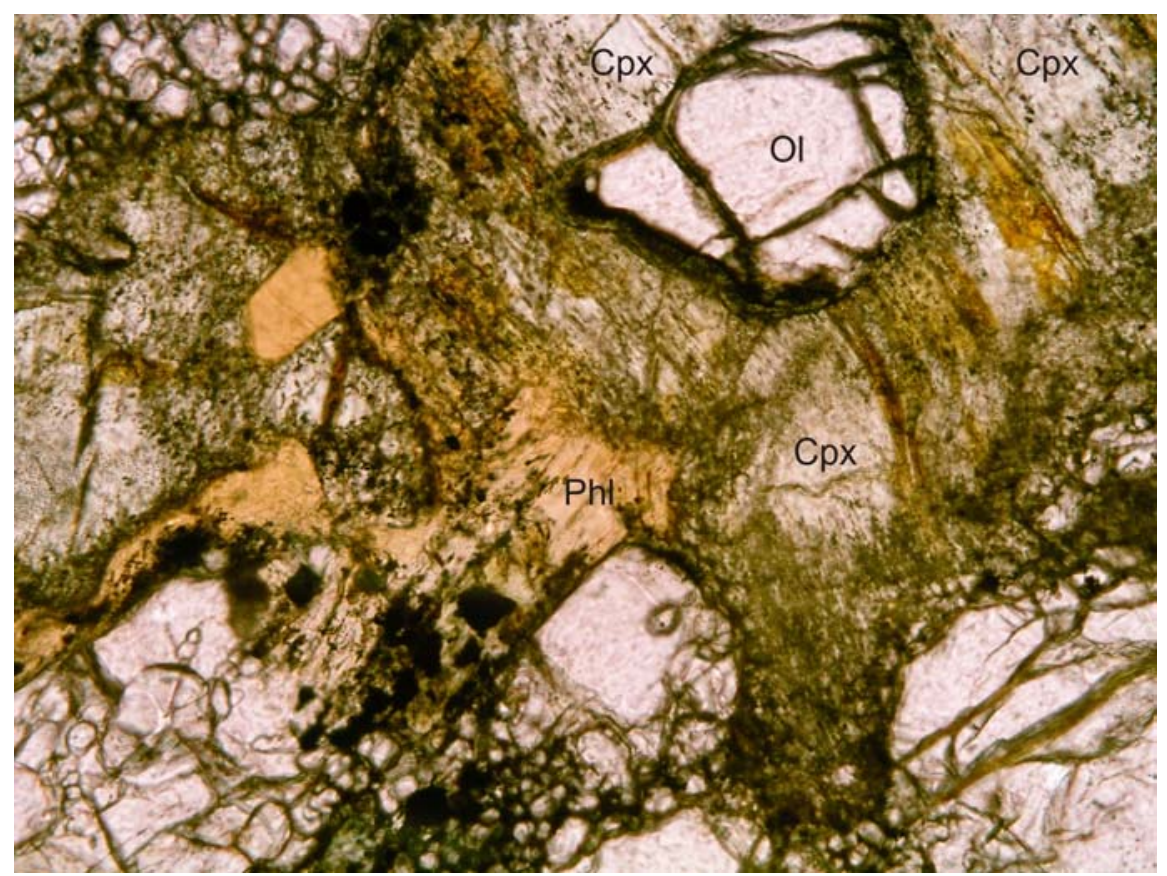

Figura 50: Relação entre olivina (Ol), clinopiroxênio (Cpx) e flogopita (Phl) mais tardia. Polarizadores paralelos. Lado maior da foto: $2,03 \mathrm{~mm}$.

\section{Xenólito KIxm4}

Este xenólito apresenta $2 \times 3 \mathrm{~cm}$ com porções de cor verde amarelado/ amarronzado e granulação média a grossa. Macroscopicamente são observadas venulações com $1 \mathrm{~mm}$ de espessura que se conectam a um bolsão micáceo de cor cinza escuro, com cerca de $1 \mathrm{~cm}$ localizado próximo ao contato com o kimberlito (Figura 51). 
A composição modal do xenólito é de espinélio-flogopita dunito e a textura é protogranular. A olivina ocorre na forma de cristais anédricos, em parte com dimensões que variam de 0,1 a $0,5 \mathrm{~mm}$ e em parte maiores, com até $8 \mathrm{~mm}$. Extinção ondulante e bandas de deformação são observadas nos cristais.

Cristais de ortopiroxênio são raros, ocorrendo apenas como pequenos núcleos de cor cinza amarronzado preservados em meio a sua alteração fibrosa característica já descrita nos outros xenólitos. Esses pequenos cristais estão em contato com clinopiroxênio próximo aos bolsões. Cristais de clinopiroxênio podem ser encontrados próximos e no interior dos bolsões. Nesse caso são anédricos, com cerca de $0,5 \mathrm{~mm}$ e incolores. Apresentam concentração de inclusões fluidas.

A lâmina apresentou dois bolsões interligados: um pequeno com $3 \mathrm{~mm}$ e outro com 1 cm de dimensão maior. Os bolsões são compostos por flogopita, cristais de minerais opacos, clinopiroxênio e subordinadamente carbonato (Figura 51). Os cristais de flogopita estão presentes somente nesses bolsões e apresentam 0,3 a 0,6 mm, sendo em sua maioria subédricos, com pleocroísmo normal variando de laranja amarronzado a marrom acinzentado e frequentes inclusões de pequenos cristais de minerais opacos. Cristais maiores de minerais opacos também ocorrem estritamente nos bolsões, sendo por vezes subédricos e atingindo dimensões de até $2 \mathrm{~mm}$. Esses cristais maiores apresentam uma série de microfraturas regulares.

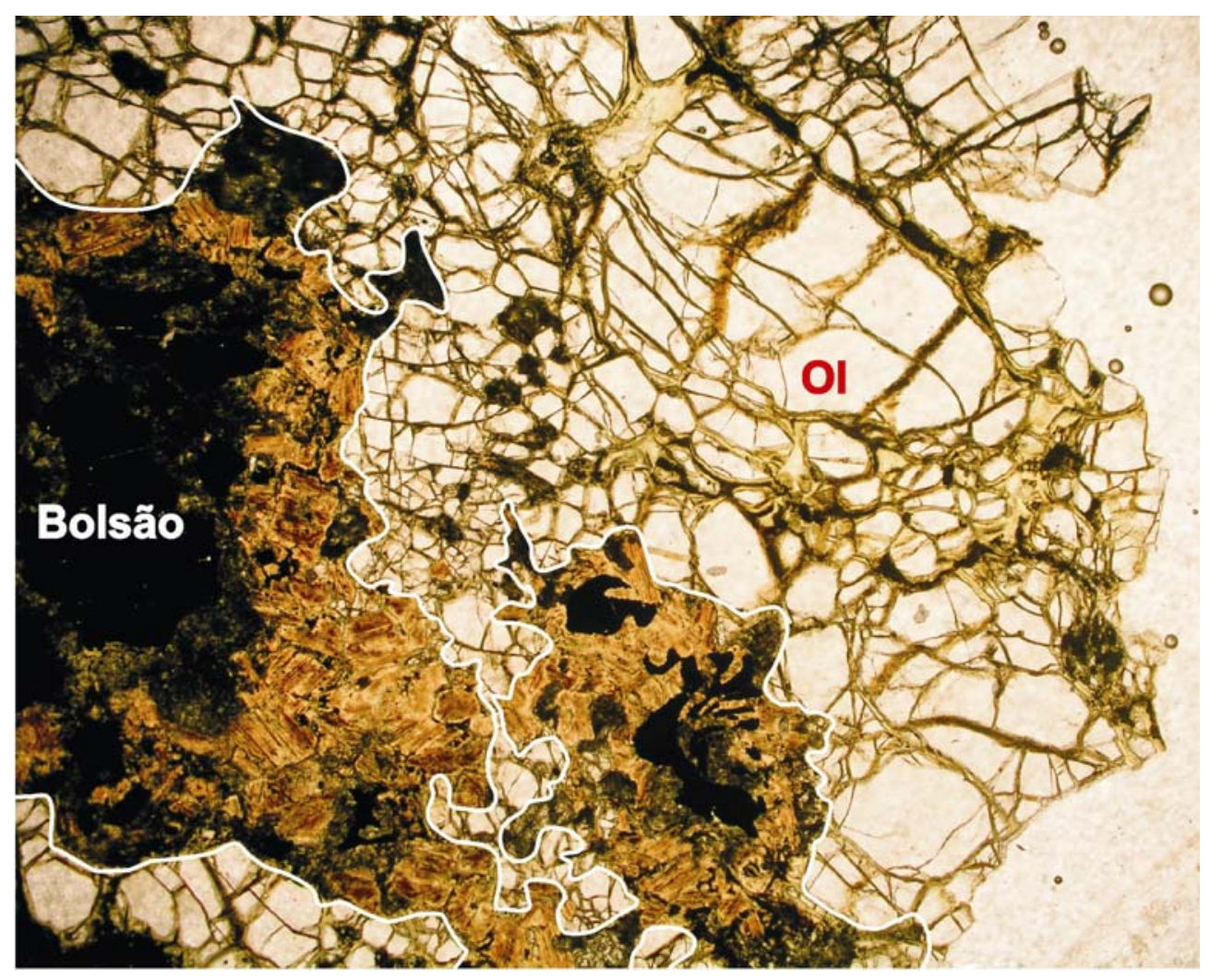

Figura 51: Fotomicrografia do xenólito Klxm4 com destaque para os bolsões. Polarizadores paralelos. Lado maior da foto: $10,4 \mathrm{~mm}$. 
Os dois bolsões também apresentam zoneamento similar ao observado na amostra Klxm2. A borda apresenta predomínio de flogopita, e é seguida internamente por clinopiroxênio e carbonato. O núcleo é ocupado pelos cristais maiores de minerais opacos.

\section{Xenólito KIxm6}

Este xenólito tem dimensões de $1,5 \times 2 \mathrm{~cm}$, forma irregular, cor cinza escuro esverdeado e granulação grossa com contatos curvados com o kimberlito observados macroscopicamente. A composição modal é de um espinélio-flogopita dunito. A lâmina mostra porções com textura transicional entre protogranular e porfiroclástica. A fotomicrografia do xenólito encontra-se na Figura 52.

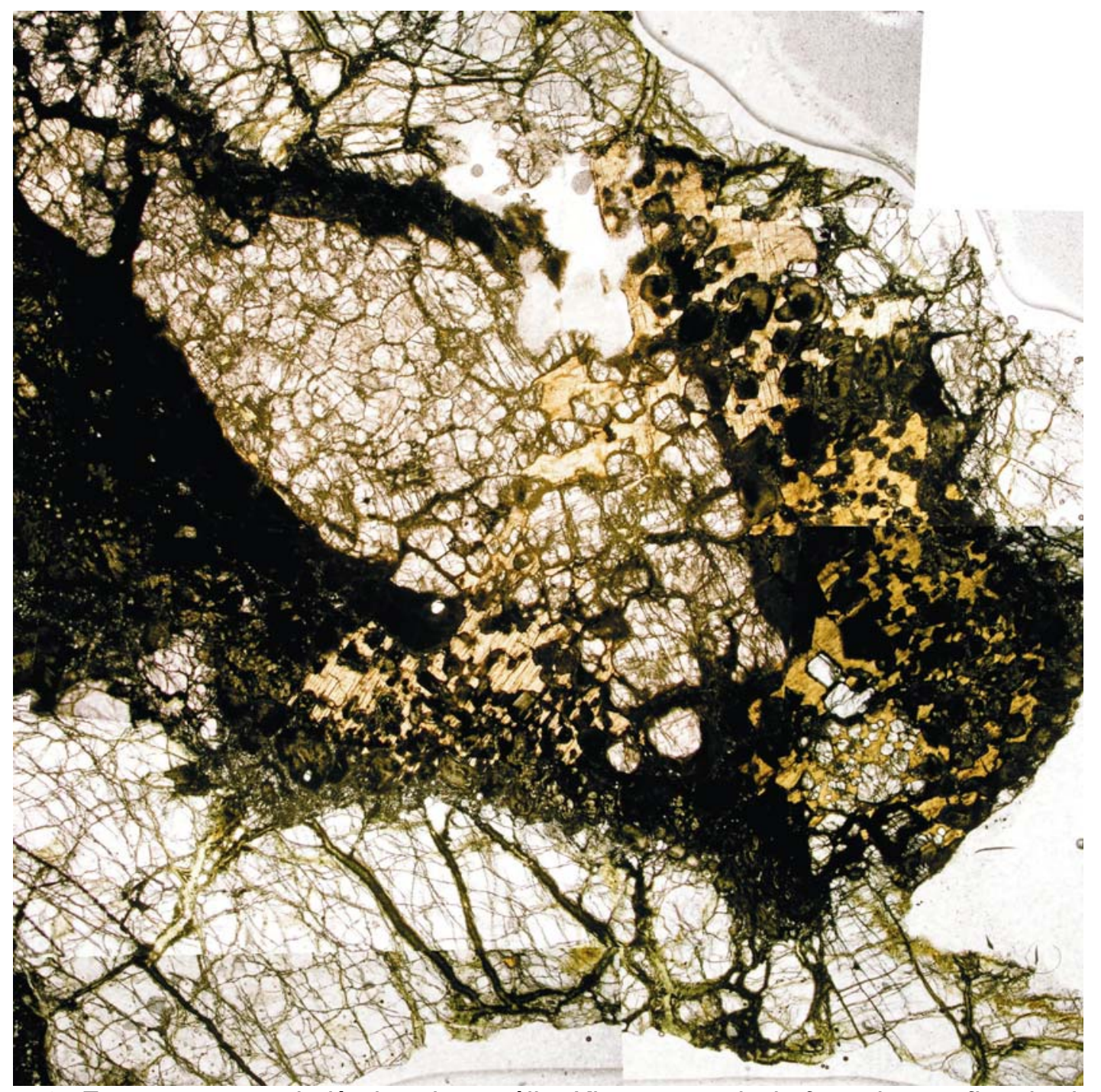

Figura 52: Fotomontagem da lâmina do xenólito KIxm6 a partir de fotomicrografias tiradas com objetiva de 1,25x. Lado maior da montagem: 1,7 cm. Lado menor da montagem: 1,2 cm. Lâmina com espessura de $60 \mu \mathrm{m}$. 
Cristais de olivina da porção com textura transicional ocorrem na forma de neoblastos muito pequenos $(\sim 0,02 \mathrm{~mm})$, anédricos, presentes próximos a microfraturas de cristais maiores de olivina $(0,5 \mathrm{~mm}$ a até $7 \mathrm{~mm}$, com extinção ondulante) também preenchidas por minerais opacos e serpentina. Trilhas de inclusões fluidas são observadas próximas a essas regiões. Essa porção mais grossa está em contato com banda composta basicamente por olivina, com 0,5 a $0,7 \mathrm{~mm}$, com contatos retos entre si por vezes poligonizados com ângulos de $120^{\circ}$ (Figura 53). Em todo o xenólito ocorrem porções com cristais de flogopita deformados, por vezes intersticiais e poiquilíticos que englobam pequenos cristais de olivina (Figura 54).

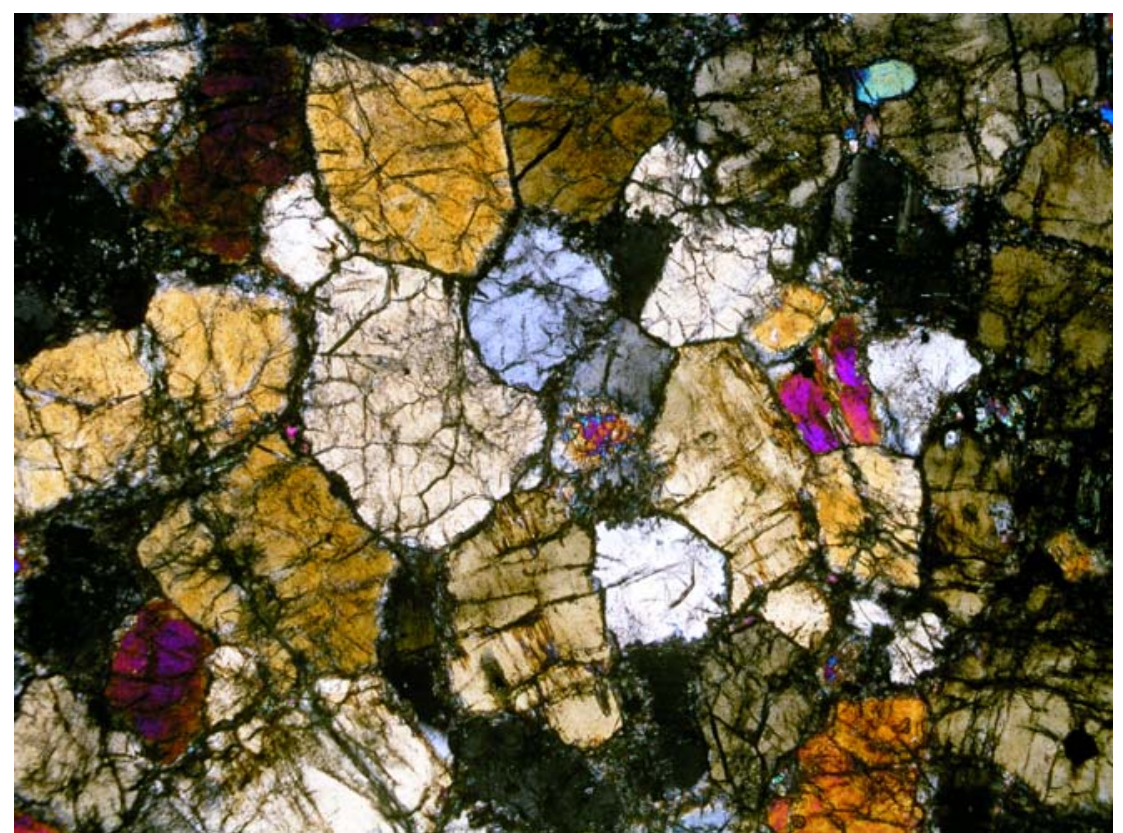

Figura 53: Porção mais fina do xenólito Klxm6 com cristais de olivina com contatos retos por vezes poligonizados. Polarizadores cruzados. Lado maior da foto: $3,25 \mathrm{~mm}$.

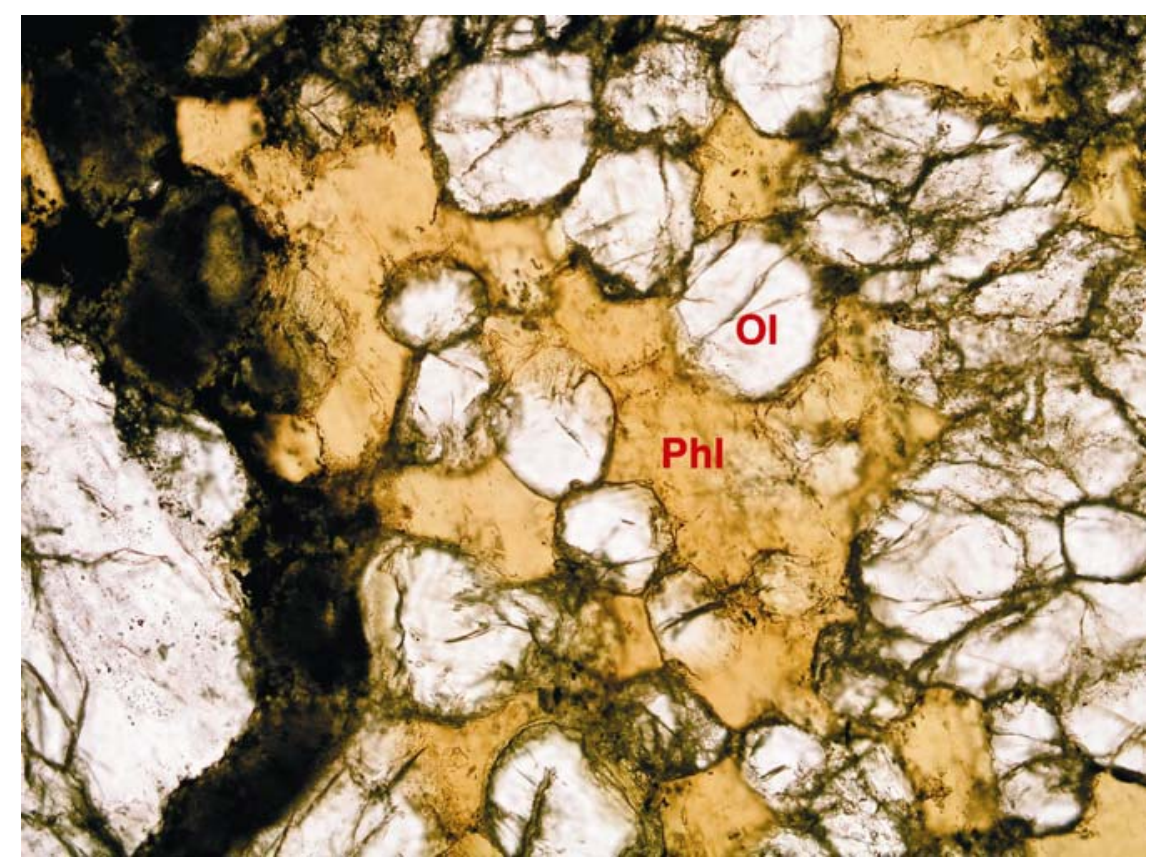

Figura 54: Cristal poiquilítico de flogopita com inclusões de pequenos cristais de olivina. Polarizadores paralelos. Lado maior da foto: $3,25 \mathrm{~mm}$. 


\subsubsection{Grupo 3: Xenólitos com predominância de fases metassomáticas}

\section{Xenólito KIXm3}

O xenólito Klxm3 apresenta dimensão maior de $1,5 \mathrm{~cm}$. Macroscopicamente mostra estrutura bandada composta por bandas de cor cinza escuro e brilho metálico com 1 a $1,5 \mathrm{~cm}$ de comprimento e $2 \mathrm{~mm}$ de largura. As bandas de brilho metálico se alternam com bandas mais claras de granulação fina a média, com espessura de 1 a $5 \mathrm{~mm}$. A composição modal é de ilmenita-clinopiroxênio glimmerito com priderita e rutilo.

A fotomicrografia do xenólito é apresentada na Figura 55. Em lâmina é possível observar que as bandas metálicas (podem ser individualizadas três) são compostas por minerais opacos e flogopita. As bandas mais claras são formadas predominantemente por clinopiroxênio, flogopita, cristais pequenos de minerais opacos e relíquias de cristais de olivina. No geral os cristais não apresentam deformação (e.g. dobras e kinks).

Cada banda metálica apresenta uma "massa policristalina" de minerais opacos. Essa "massa" tem tamanho entre 1 e $1,5 \mathrm{~cm}$, e seus cristais apresentam contato bastante irregular com clinopiroxênio e flogopita. Análises por WDS e EDS mostram que os minerais opacos correspondem a cristais de principalmente ilmenita e secundariamente priderita, rutilo e outras fases ainda não identificadas com uma relação bastante complexa.

Inclusões vermiformes de tamanho pequeno $(0,1$ a $0,5 \mathrm{~mm})$ de calcita e outras fases minerais também ocorrem em algumas porções das bandas metálicas concentradas no núcleo da massa principal e formam uma textura simplectítica (Figuras 56 e 57). As inclusões vermiformes de calcita apresentam continuidade óptica com um cristal de carbonato maior (2,2 $\mathrm{mm}$ ) presente fora da massa de minerais opacos. Este carbonato apresenta tom levemente amarelado e inclusões de cristais muito finos $(0,1$ a $0,3 \mathrm{~mm})$, euédricos, de relevo alto e esverdeados (Figura 58). Também próximo à borda desse carbonato ocorrem inclusões de cristais muito pequenos $(<0,1 \mathrm{~mm})$ de relevo muito alto, incolores e euédricos (Figura 59). Esse carbonato é cortado por veio carbonático que corta o kimberlito e o xenólito e representa, portanto, uma fase de alteração posterior ao cristal com inclusões. 


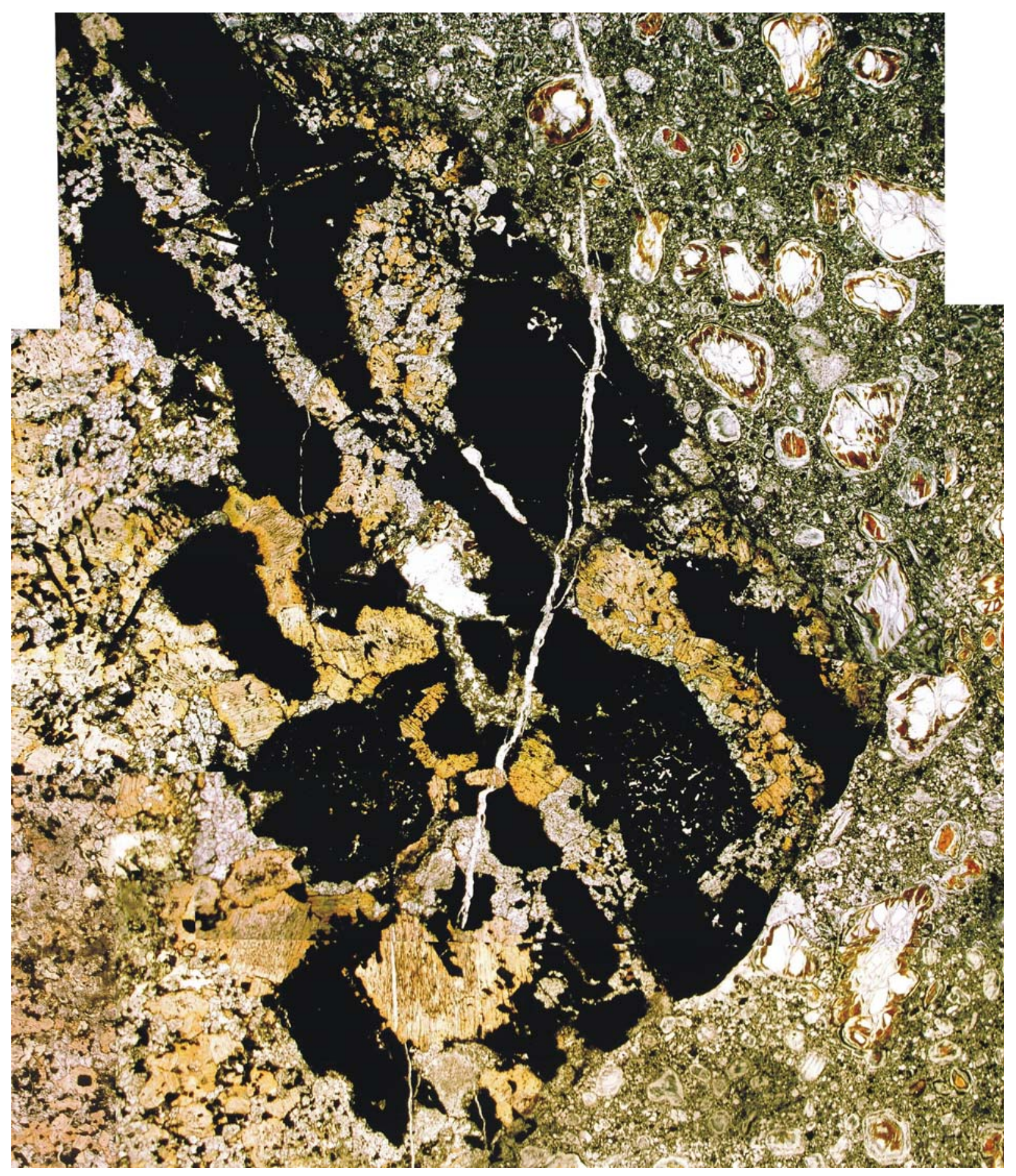

Figura 55: Fotomontagem da lâmina do xenólito KIxm3 a partir de fotomicrografias tiradas com objetiva de 1,25x. Lado maior da montagem: 1,5 mm. Lado menor da montagem: 1,3 mm. 


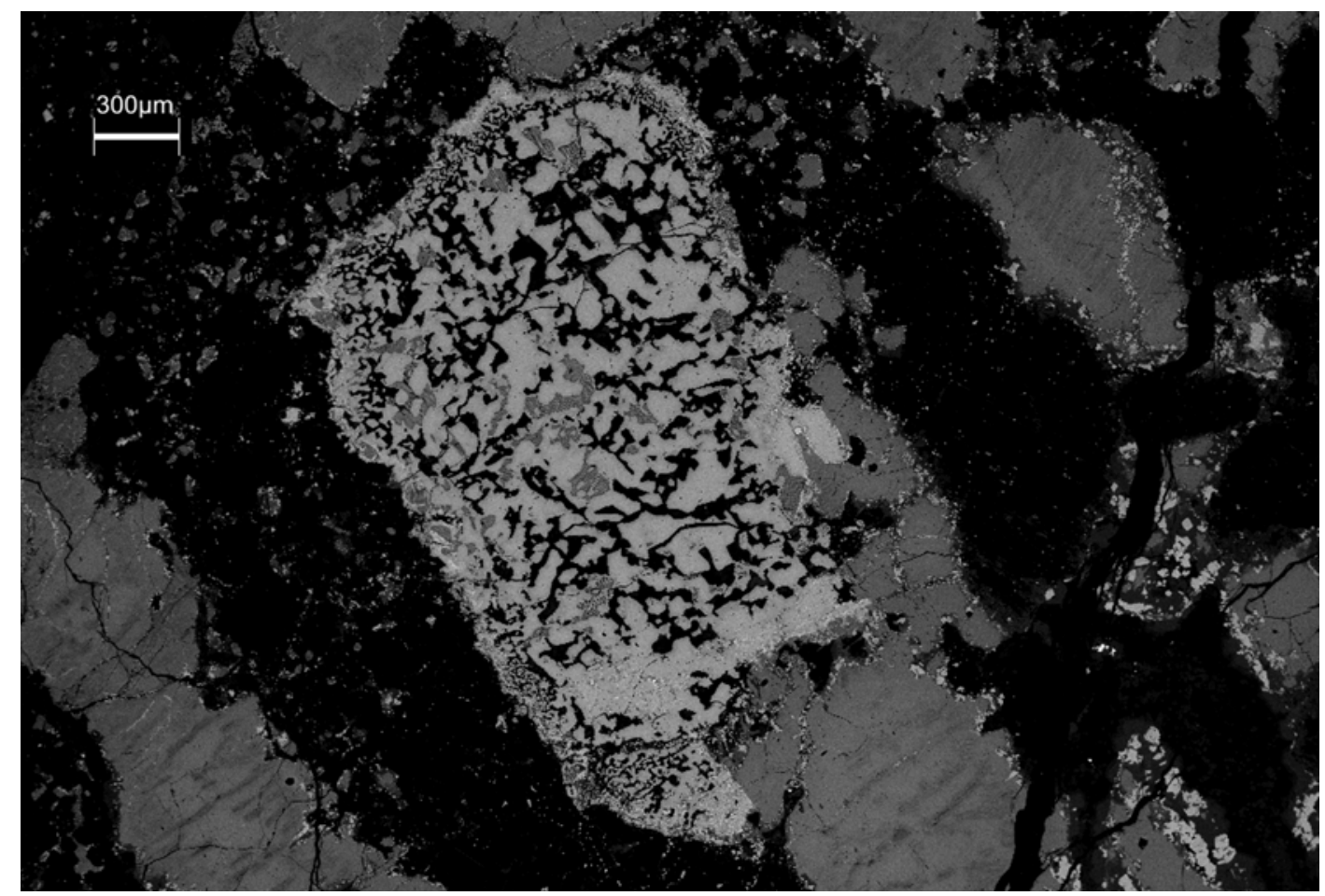

Figura 56: Imagem de elétrons retroespalhados (BSE) da massa policristalina de minerais opacos com inclusões vermiformes.

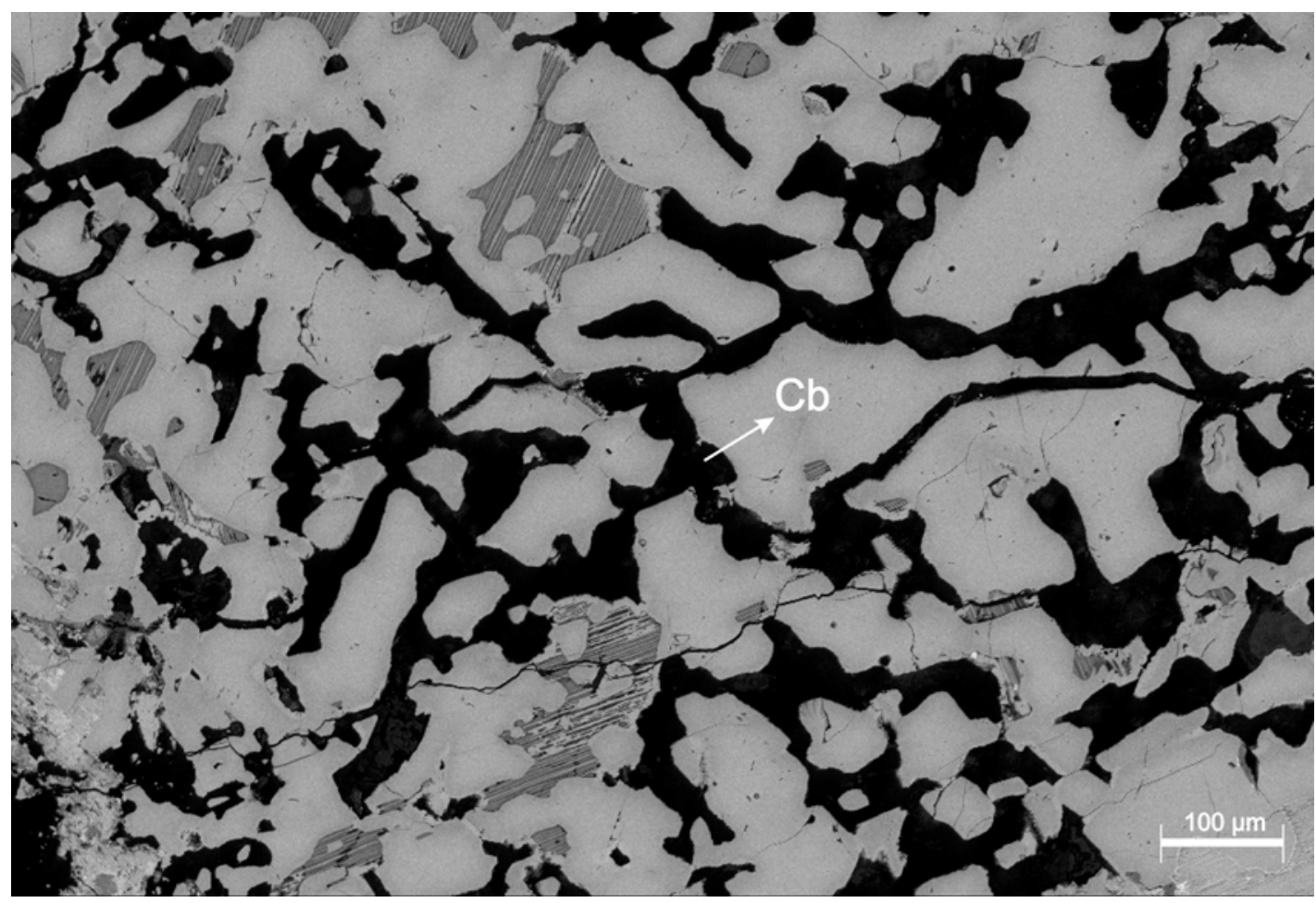

Figura 57: Indicação das inclusões vermiformes de calcita (Cb) no detalhe nas inclusões mostradas na figura anterior. 


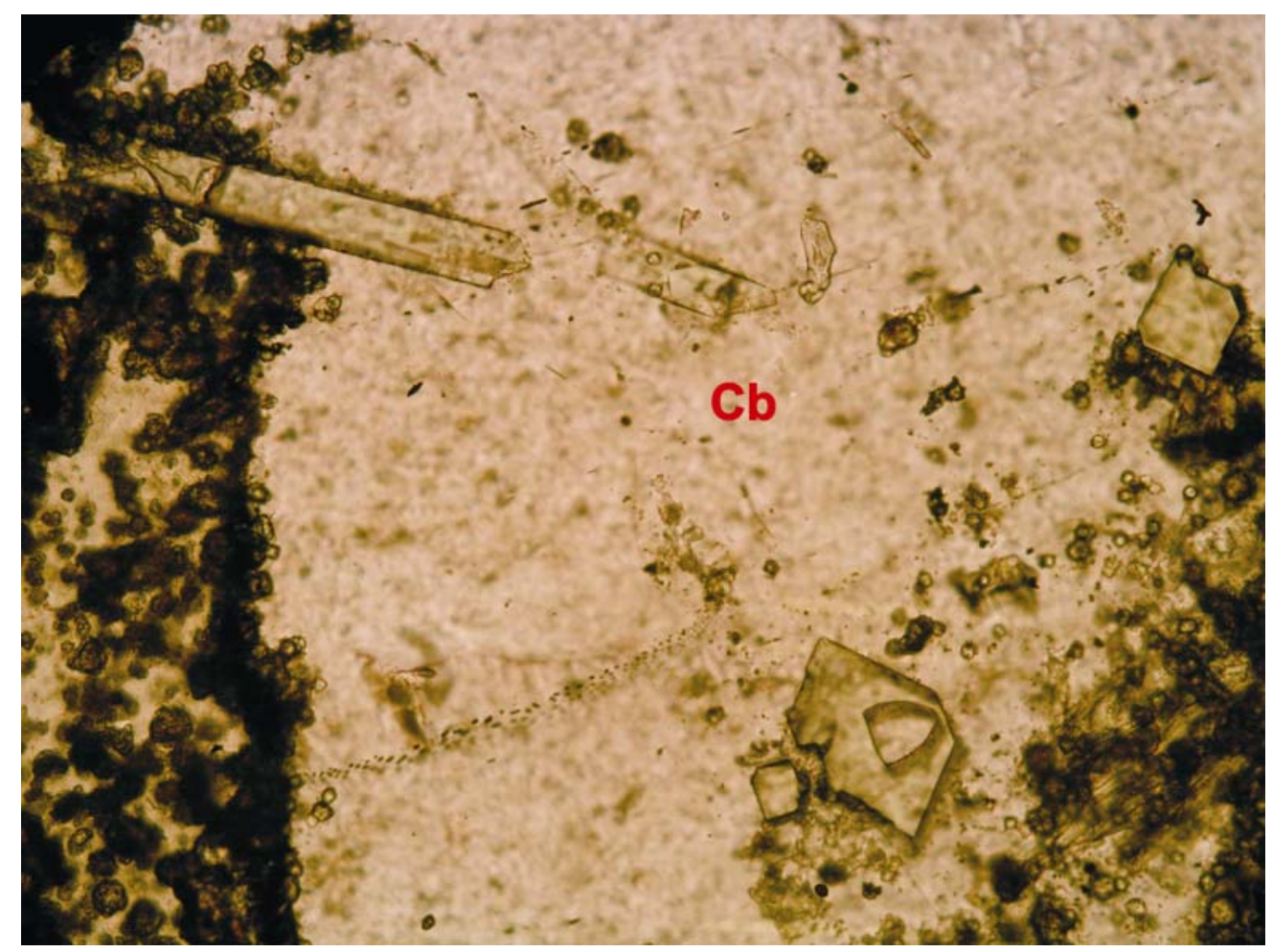

Figura 58: Inclusões de cristal euédrico, esverdeado em carbonato. Lado maior da foto: 0,65 mm.

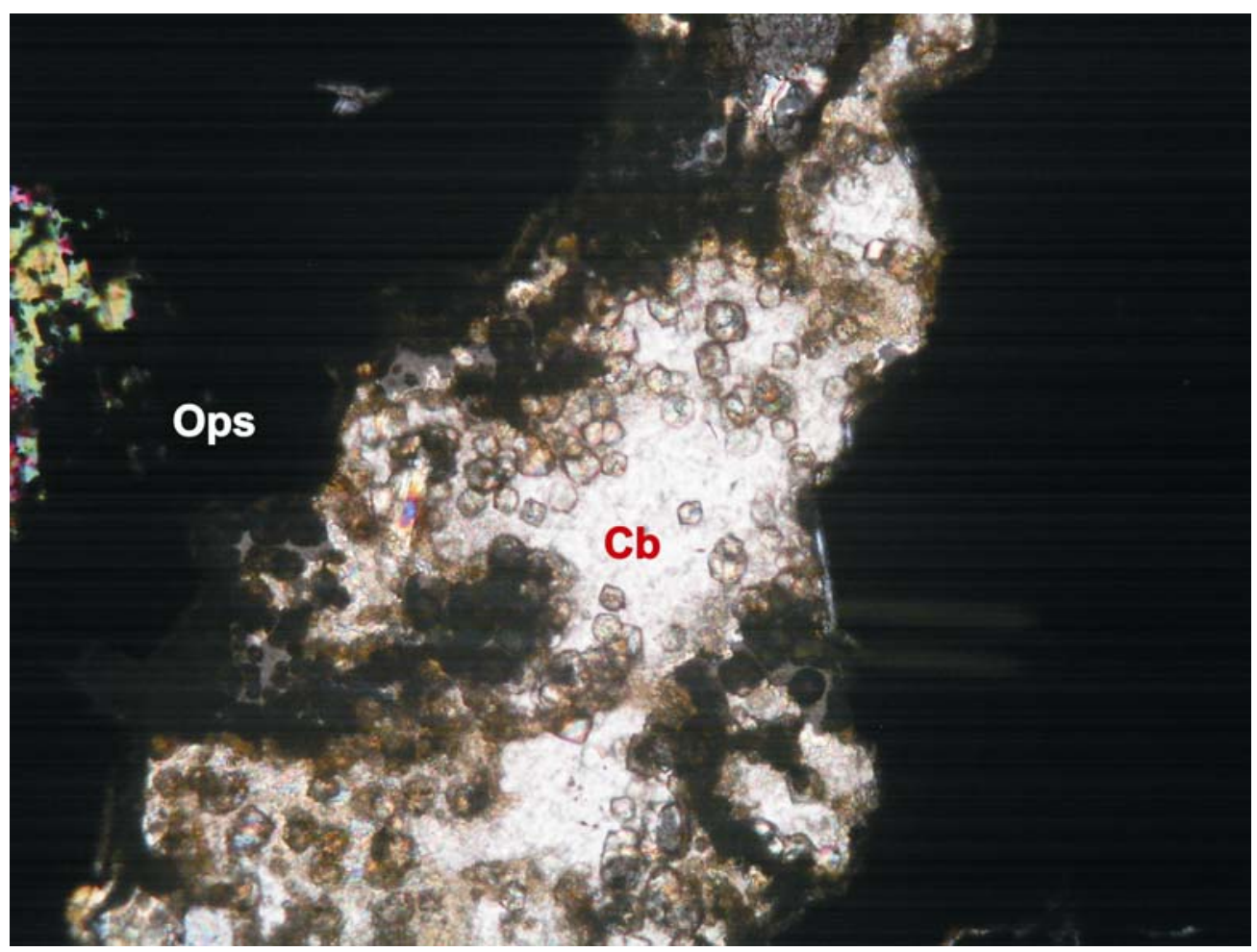

Figura 59: Inclusões em carbonato (Cb) em contato com massa de minerais opacos (Ops). Lado maior da foto: 0,65 $\mathrm{mm}$. 
A flogopita está presente com dimensões que variam de 0,3 a $2 \mathrm{~mm}$. Os cristais maiores são anédricos e apresentam zoneamento definido por núcleos mais claros com pleocroísmo normal que varia de laranja acinzentado a cinza amarronzado e bordas mais escuras com pleocroísmo também normal de laranja escuro a marrom alaranjado. Cristais de minerais opacos (ilmenita), priderita, rutilo e cristais incolores de alto relevo, com até $1 \mathrm{~mm}$, ocorrem como inclusões na flogopita (Figura 60) e são, na maioria das vezes, alongados e ocupam as clivagens na região próxima ao núcleo. Cristais menores de flogopita presentes próximo ao contato com o kimberlito apresentam zoneamento, porém nesse caso tanto os núcleos como as bordas são escuros e ricos em inclusões de minerais opacos, de modo semelhante ao observado no grupo 2.

Os contatos entre os cristais de flogopita são na maioria das vezes retos, mas em algumas regiões podem ser interlobados. O mesmo pode acontecer entre cristais de clinopiroxênio (Figura 61).

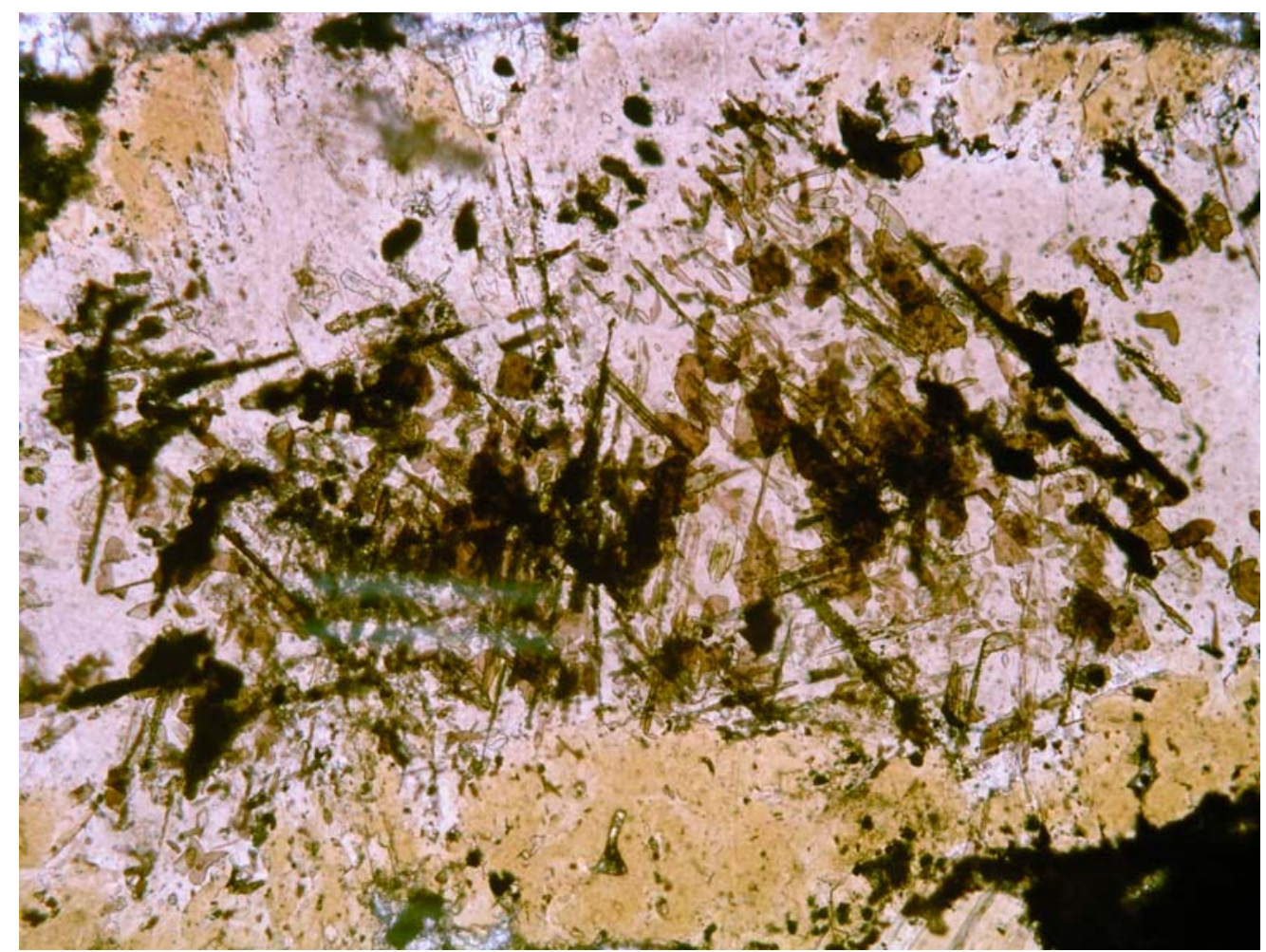

Figura 60: Inclusões e zoneamento em flogopita. Polarizadores paralelos. Lado maior da foto: $0,65 \mathrm{~mm}$. 


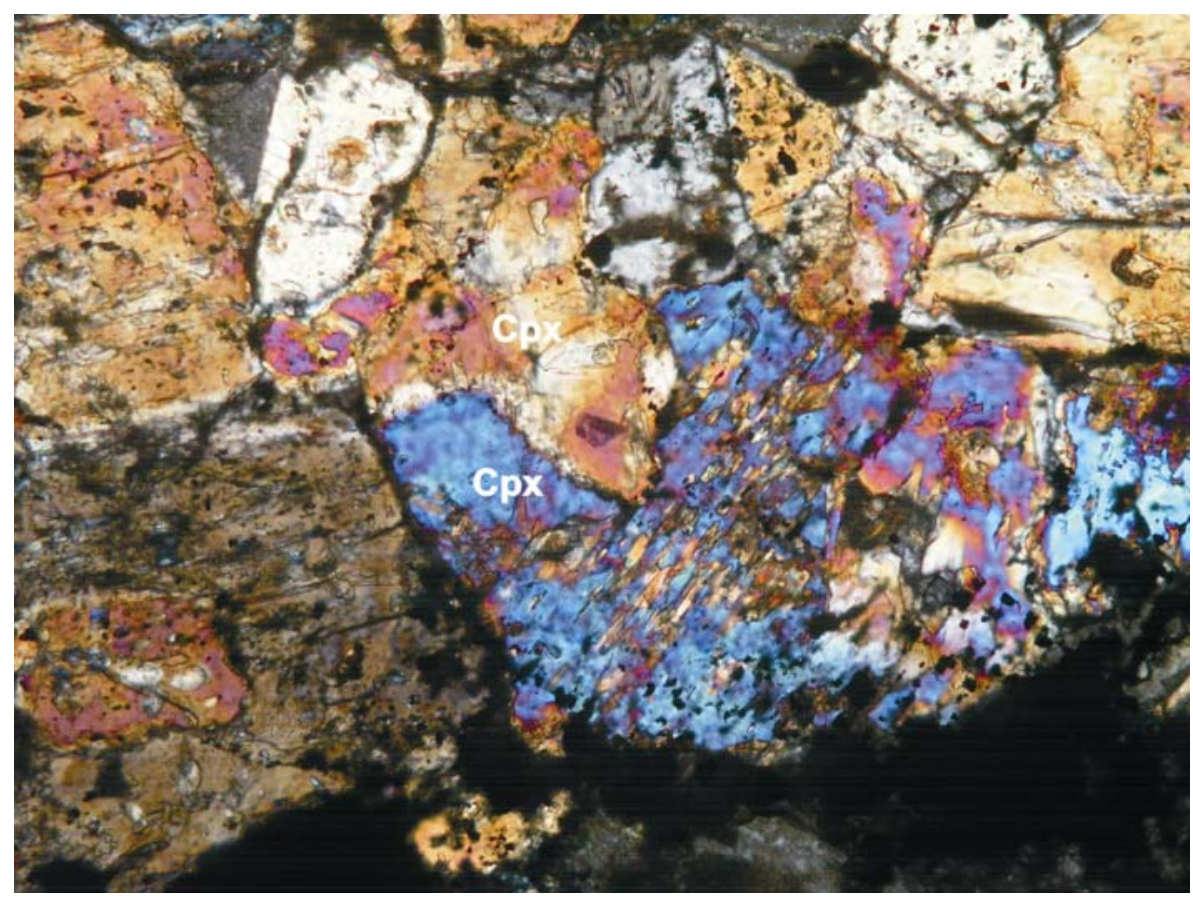

Figura 61: Cristais de clinopiroxênio em contato interlobado. Polarizadores cruzados. Lado maior da foto: 0,65 $\mathrm{mm}$.

Os cristais de clinopiroxênio são anédricos, com dimensões entre 0,2 e 0,5mm. Apresentam muitas inclusões fluidas, inclusões de cristais de minerais opacos e flogopita. Estão em contato irregular com os cristais maiores de flogopita e minerais opacos.

Cristais de olivina com cerca de 0,3 mm ocorrem apenas em uma porção do xenólito, e em geral (com exceção de um cristal, Figura 62) apresentam abundantes inclusões de minerais opacos.

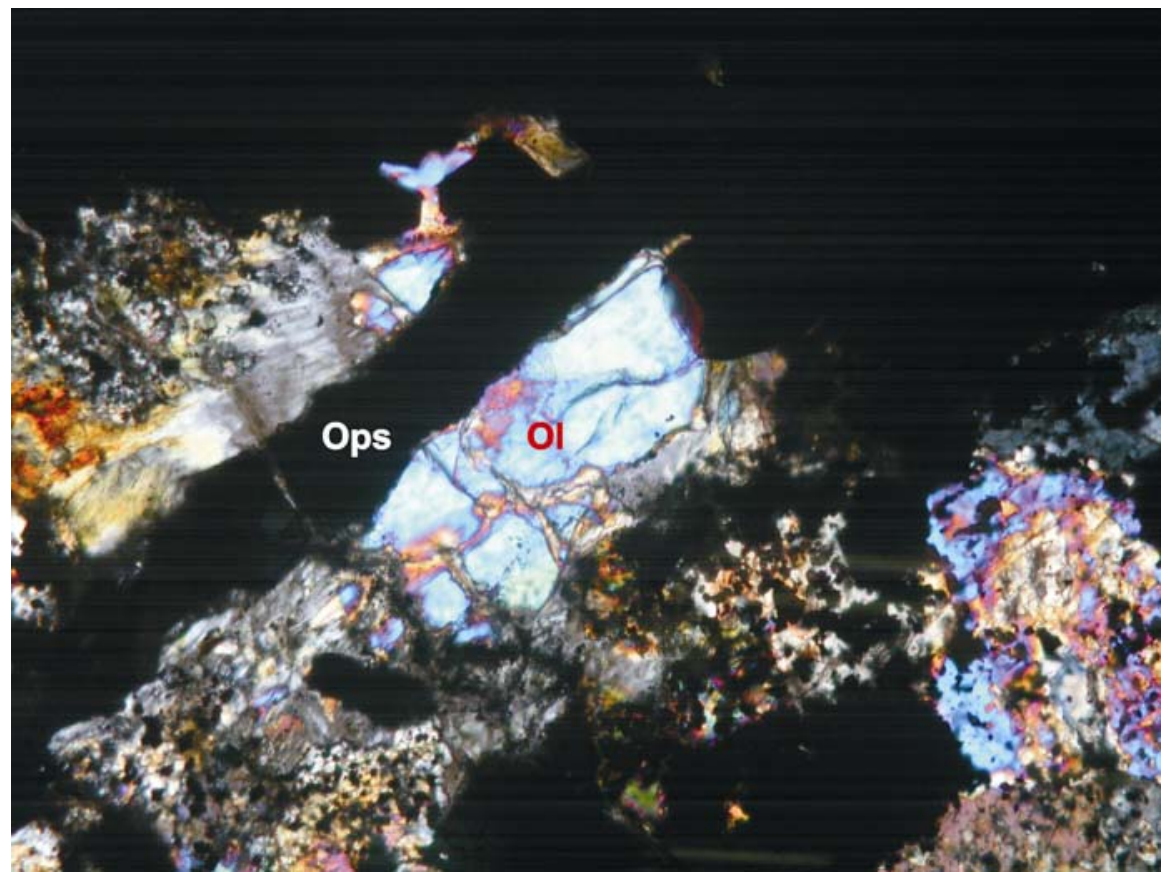

Figura 62: Cristal de olivina sem inclusões (centro da foto) em contato com cristal de mineral opaco alongado. Polarizadores cruzados. Lado maior da foto: 0,65 $\mathrm{mm}$. 
Porções com serpentina de cor amarelo esverdeado com cristais de minerais opacos nas bordas estão presentes nas bandas mais claras.

No geral os minerais deste xenólito mostram relações complexas, em parte devido à natureza dos contatos e inclusões e à variedade de minerais opacos ainda não totalmente definida.

\subsubsection{Macrocristais/Xenocristais}

Algumas lâminas petrográficas do kimberlito mostram cristais de principalmente olivina com 0,5 a $1 \mathrm{~cm}$ (Figura 63). Apesar de terem provável origem mantélica, esses cristais não foram objeto de estudo neste trabalho.

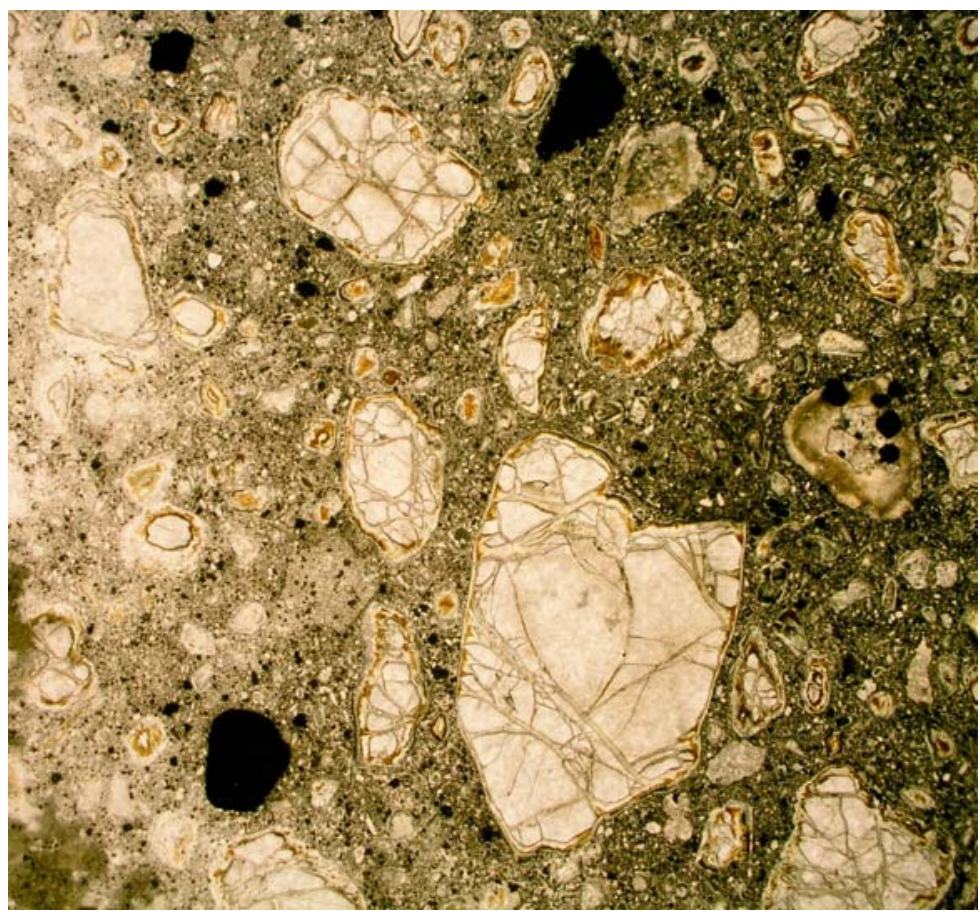

Figura 63: Cristais de olivina no kimberlito. Lado maior da foto: 10,4 $\mathrm{mm}$.

\subsection{Geoquímica de rocha total}

Os xenólitos maiores de Monte Carmelo (KIxm1 e Klxm2) e sua rocha encaixante (Kimberlito Limeira 1) foram submetidos a análises químicas de rocha total por ICP-OES (elementos maiores e menores) e ICP-MS (elementos menores e traços). Os resultados estão presentes no Anexo 10.

Os dois xenólitos (Klxm1 e Klxm2) apresentam teores semelhantes de $\mathrm{SiO}_{2}(\sim 40 \%)$, $\mathrm{Al}_{2} \mathrm{O}_{3}(\sim 0,8 \%), \mathrm{MnO}(\sim 0,1 \%), \mathrm{Na}_{2} \mathrm{O}(\sim 0,1 \%)$ e $\mathrm{K}_{2} \mathrm{O}(\sim 0,4 \%)$. O xenólito KIxm2 mostrou maiores 
proporções de $\mathrm{TiO}_{2}(0,5 \%), \mathrm{Fe}_{2} \mathrm{O}_{3 \mathrm{~T}}(10,3 \%), \mathrm{CaO}$ (3,3\%), Y (5 ppm), $\mathrm{Zr}$ (407 ppm), $\mathrm{Ba}$ (327 ppm), Nb (23 ppm), Hf (11 ppm), Ta (2 ppm) e ETR (e.g. 33 ppm de La). O xenólito Klxm1 apresentou maior proporção de $\mathrm{MgO}$ (43\%) e Sr (391 ppm). O kimberlito encaixante apresentou maiores concentrações para quase todos os elementos com exceção de alguns óxidos como: $\mathrm{SiO}_{2}(30 \%), \mathrm{MgO}(31 \%)$ e $\mathrm{Na}_{2} \mathrm{O}$ (<l.d.).

A Figura 64 mostra os padrões de elementos terras-raras dos xenólitos em comparação com o do kimberlito normalizados pelo condrito C1 de Mcdonough \& Sun (1995). O xenólito Klxm2, com razão $(\mathrm{La} / \mathrm{Yb})_{\mathrm{N}}$ extremamente elevada ( 280), tem maior concentração em ETR em relação a Klxm1, mas ambos mostram enriquecimentos em ETRL. Entre os ETRP Tb, Yb e Lu apresentam as mesmas concentrações nos dois xenólitos. O kimberlito também mostra enriquecimento em ETRL, com razão $(\mathrm{La} / \mathrm{Yb})_{\mathrm{N}}$ de 101.

Os padrões de elementos incompatíveis normalizados pelo manto primitivo de Sun \& McDonough (1989) (Figura 65) mostra o maior enriquecimento para esses elementos de KIxm2 em relação à Klxm1. Anomalia negativa de Ti ocorre nos dois xenólitos, no entanto anomalia positiva de $\mathrm{Sr}\left((\mathrm{Nd} / \mathrm{Sr})_{\mathrm{N}}=0,05\right)$ ocorre somente em Klxm1. O kimberlito é mais enriquecido e também apresenta anomalia negativa de $\mathrm{Ti}\left((\mathrm{Gd} / \mathrm{Ti})_{\mathrm{N}}=3,5\right)$.

A análise de xenólito da região de Coromandel apresentada por Carlson et al., (2007) mostrou teores de $\mathrm{TiO}_{2}(0,24 \%), \mathrm{MgO}(40 \%)$ e $\mathrm{P}_{2} \mathrm{O}_{5}(0,18 \%)$ mais parecidos com os encontrados no xenólito Klxm2. Tanto Klxm2 como Klxm1 apresentam menores teores de $\mathrm{Na}_{2} \mathrm{O}$ e maiores de $\mathrm{K}_{2} \mathrm{O}$ em relação ao resultado de Carlson et al., (2007).

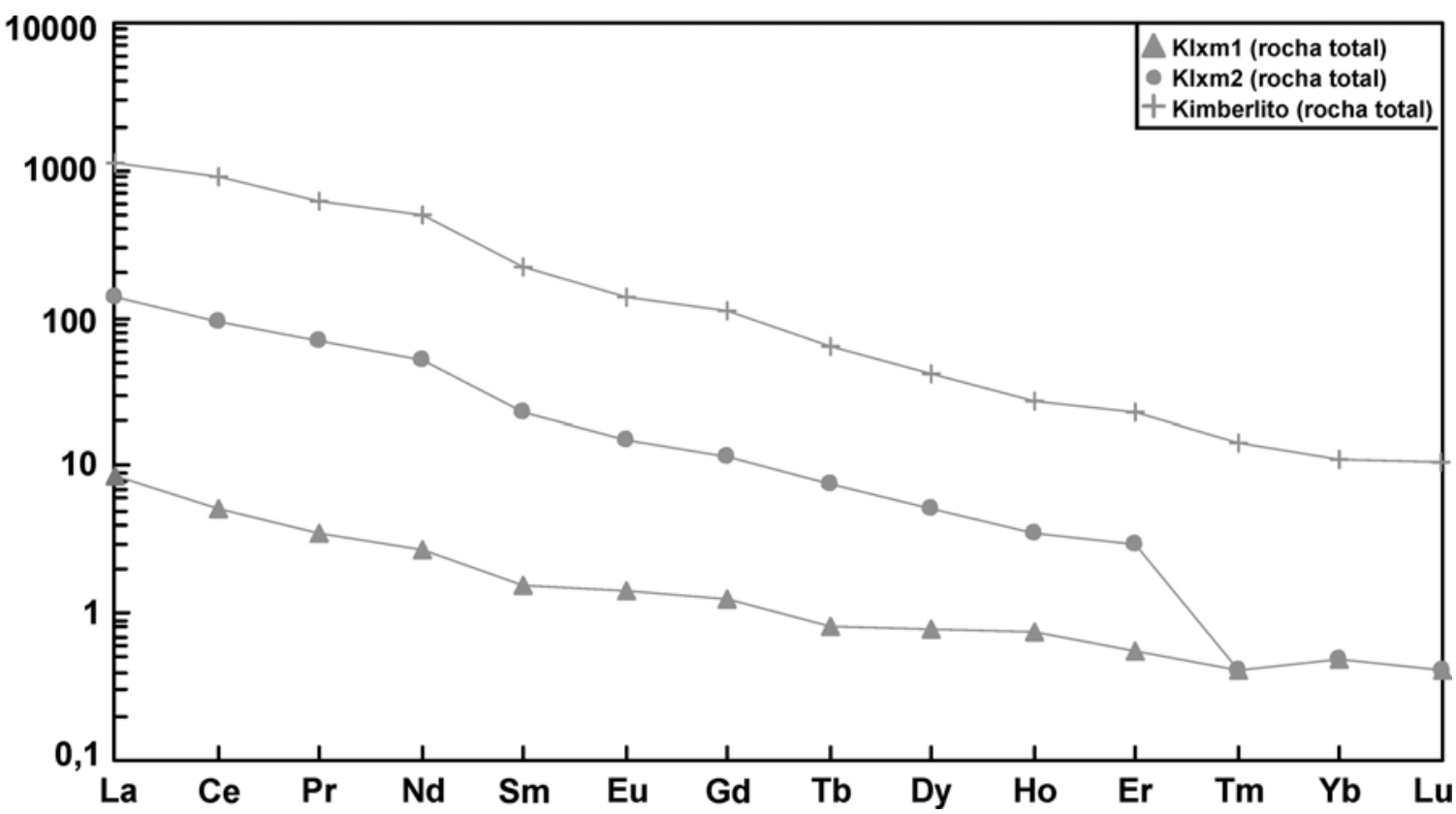

Figura 64: Padrões de elementos terras-raras de análises de rocha total dos xenólitos e do Kimberlito Limeira 1 normalizados ao padrão condrítico C1 de McDonough \& Sun (1995). 


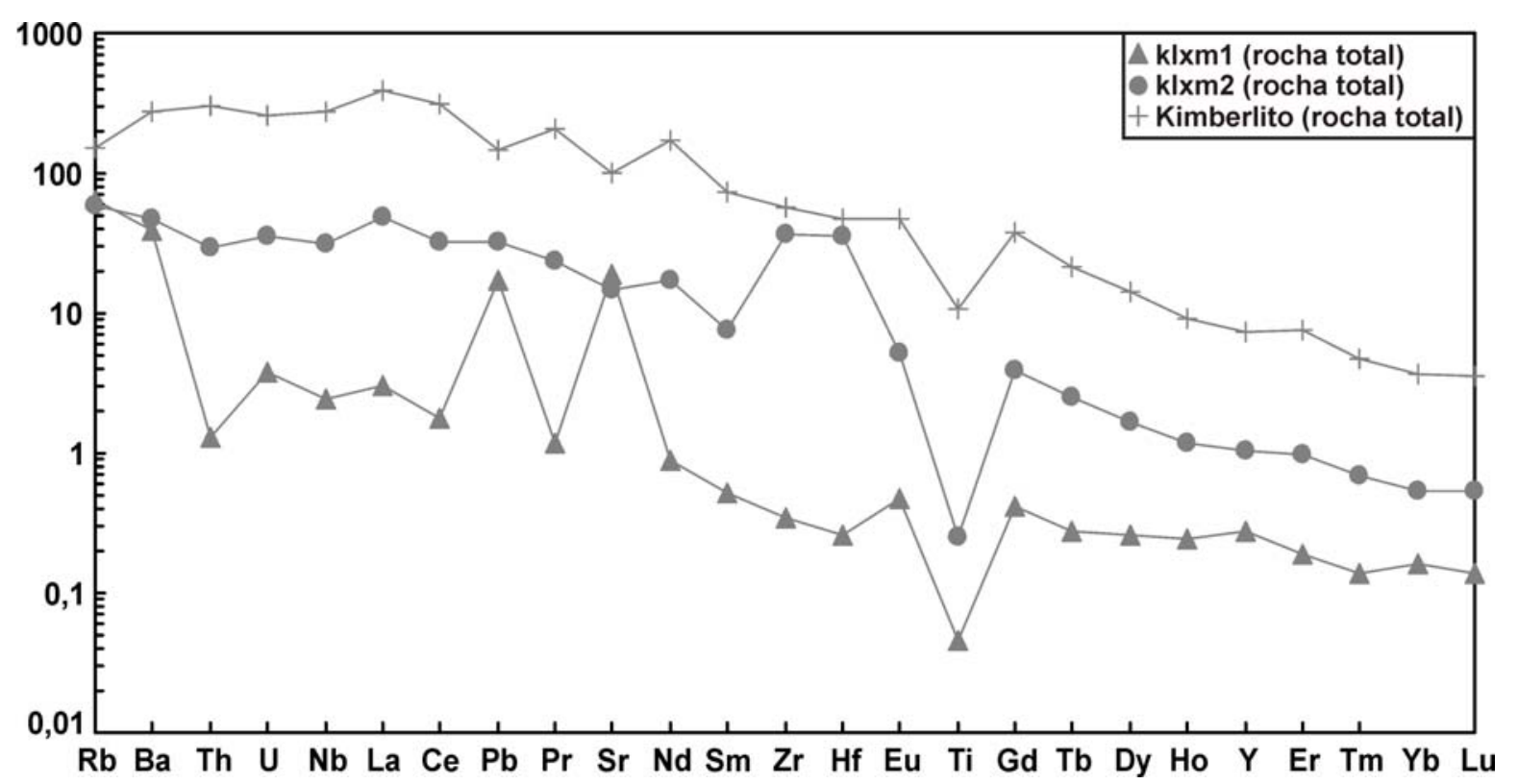

Figura 65: Padrões de elementos incompatíveis de análises de rocha total dos xenólitos e do Kimberlito Limeira 1 normalizados pelo manto primitivo de Sun \& McDonough (1989).

\subsection{Química Mineral}

\subsubsection{Olivina}

Foram analisados cristais de olivina nos xenólitos do grupo 1 (Klxm1), 2 (Klxm2) e 3 (Klxm3). As análises encontram-se no Anexo 1. A olivina mais magnesiana está presente no xenólito Klxm1 ( $\mathrm{Fo}_{92}$, sem distinção entre núcleo e borda), enquanto a olivina do xenólito Klxm2 é a mais pobre em magnésio $\left(\mathrm{Fo}_{88}\right)$. Os neoblastos presentes neste último xenólito apresentaram composição semelhante aos cristais maiores.

A olivina do grupo 3 (Klxm3) possui composição diferenciada com um zoneamento complexo. Um cristal com composição $\mathrm{Fo}_{90}$ apresenta 1,1\% de $\mathrm{CaO}$ e teor de $\mathrm{TiO}_{2}$ variando entre $0,04 \%$ (núcleo) e $0,21 \%$ (borda). Outro cristal tem núcleo notavelmente mais rico em $\mathrm{Fe}$ $\left(\mathrm{Fo}_{81}\right), 0,45 \%$ de $\mathrm{CaO}$ e borda com proporção de forsterita idêntica à do primeiro cristal (Fogo), mas com teores mais baixos de $\mathrm{CaO}(0,13 \%)$. Os teores de $\mathrm{NiO}$ são mais baixos em Klxm3 (até $0,1 \%$ contra $0,4 \%$ em $\mathrm{Klxm} 1$ ).

\subsubsection{Ortopiroxênio}

Foram analisados cristais de ortopiroxênio nos xenólitos dos grupos 1 (Klxm1) e 2 (Klxm2). As análises encontram-se no Anexo 2. As composições foram lançadas no diagrama de Morimoto (1988) (Figura 66) onde as análises dos dois xenólitos se situam no campo da 
enstatita, sendo que os de Klxm2 são ligeiramente mais ricos em $\mathrm{Fe}\left(\mathrm{Wo}_{2} \mathrm{En}_{88} \mathrm{Fs}_{10}\right)$, sem variação significativa entre núcleo e borda.

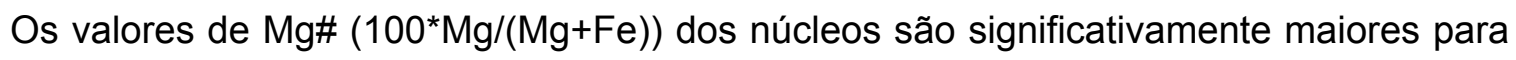
KIxm1 (91,7 a 91,9) em relação a Klxm2 (89,8 e 89,9), sendo que em Klxm1 as bordas mostram por vezes valores um pouco menores. O xenólito Klxm2 apresentou cristais com menores teores de $\mathrm{Al}_{2} \mathrm{O}_{3}$ (até $0,3 \%$ ) e maiores de $\mathrm{TiO}_{2}$ (até $0,3 \%$ ). O gráfico $\mathrm{Al}_{2} \mathrm{O}_{3} \times \mathrm{TiO}_{2}$ (Figura 67a) mostra a correlação negativa entre esses óxidos. Relação inversa é observada entre $\mathrm{Al}_{2} \mathrm{O}_{3}$ e $\mathrm{Mg \#} \mathrm{(Figura} \mathrm{67b).} \mathrm{Teores} \mathrm{de} \mathrm{Cr}_{2} \mathrm{O}_{3}$ são um pouco maiores em Klxm1 com valor máximo de $0,5 \%$.

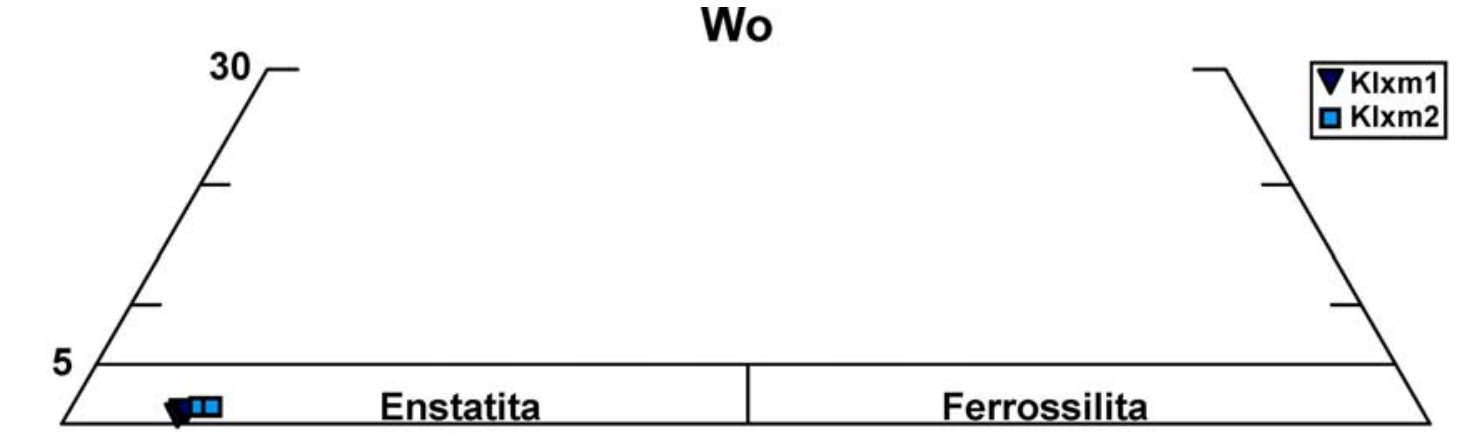

En Fs

Figura 66: Diagrama de Morimoto (1988) com classificação dos cristais de ortopiroxênio analisados em xenólitos do manto do Kimberlito Limeira 1.

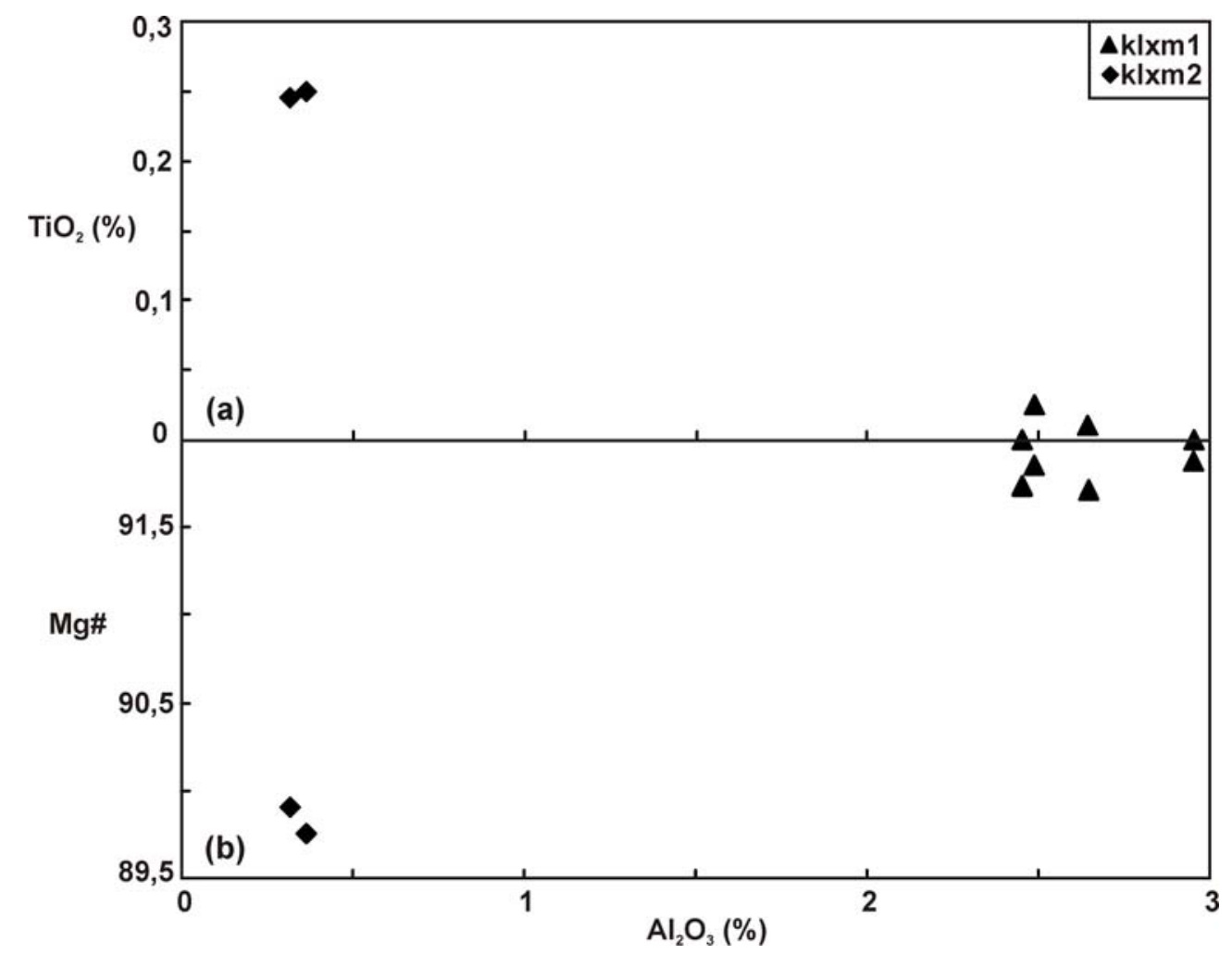

Figura 67: Composições de núcleos de cristais de ortopiroxênio mostrando a correlação negativa entre $\mathrm{Al}_{2} \mathrm{O}_{3}$ e $\mathrm{TiO}_{2}$ (a) e a correlação positiva entre $\mathrm{Al}_{2} \mathrm{O}_{3}$ e $\mathrm{Mg \#}(\mathrm{Mg} /(\mathrm{Mg}+\mathrm{Fe}))$ (b) em xenólitos do manto do Kimberlito Limeira 1. 


\subsubsection{Clinopiroxênio}

Os resultados das análises de encontram-se no Anexo 3. As análises químicas de clinopiroxênio dos diferentes xenólitos foram representadas no quadrilátero (Quad) com a divisão de campos de Morimoto (1988) presentes na Figura 68. Essa figura também mostra diferença composicional dos xenólitos (diagrama WEF $x \mathrm{Jd} \times \mathrm{Ae}$ ) quanto à proporção de Jadeíta e Aegirina, sendo o xenólito Klxm2 do grupo 2 com o cristal com o maior teor em Aegirina ((WEF) $\left.)_{90} \mathrm{Jd}_{0} \mathrm{Ae}_{10}\right)$.

No geral, os cristais dos xenólitos Klxm1 $\left(\mathrm{Wo}_{48} \mathrm{En}_{49} \mathrm{Fs}_{3}\right)$ e $\mathrm{Klxm} 3\left(\mathrm{Wo}_{45} \mathrm{En}_{44} \mathrm{Fs}_{11}\right.$ a $\mathrm{Wo}_{50} \mathrm{En}_{46} \mathrm{Fs}_{4}$ ) podem ser classificados como diopsídio, com exceção de uma análise deste último xenólito que se situa no campo da augita cálcica $\left(\mathrm{Wo}_{44} \mathrm{En}_{46} \mathrm{Fs}_{10}\right)$. Todas as análises de Klxm2 situam-se no campo da augita cálcica $\left(\mathrm{Wo}_{42} \mathrm{En}_{52} \mathrm{Fs}_{6}\right)$. Neste xenólito, não foram constatadas diferenças químicas entre as análises dos cristais de clinopiroxênio associados ou não com os bolsões. Valores de $\mathrm{Mg \#}(\mathrm{Mg} /(\mathrm{Mg}+\mathrm{Fe}))$ de núcleos de cristais são significativamente maiores em KIxm1 (94,3 a 94,9) em relação aos outros dois grupos (89,9 a 90,2 em Klxm2). Os cristais de Klxm3 mostram muita variação nos valores de Mg\# (81,9 a $92,2)$ resultantes dos zoneamentos observados.

O clinopiroxênio de Klxm3 apresentou significativas variações químicas entre núcleo e borda principalmente quanto aos teores de $\mathrm{Al}_{2} \mathrm{O}_{3}$ (0,04\% núcleo e 0,2\% borda), $\mathrm{FeO}(2,7 \%$ núcleo e 3,8\% borda) e $\mathrm{Cr}_{2} \mathrm{O}_{3}(0,12 \%$ núcleo e $0,48 \%$ borda). Esse último óxido apresenta os menores teores em relação aos outros dois xenólitos. Até mesmo análises em regiões diferentes da borda de um mesmo cristal apresentam diferentes teores de $\mathrm{TiO}_{2}(0,14 \%$ vs. $0,54 \%), \mathrm{Al}_{2} \mathrm{O}_{3}(0,5 \%$ vs. $0,2 \%), \mathrm{FeO}(6,2 \%$ vs. $4,8 \%), \mathrm{Na}_{2} \mathrm{O}(1,6 \%$ vs. $0,9 \%)$ e $\mathrm{K}_{2} \mathrm{O}(0,01 \%$ vs. $0,2 \%)$.

Ocorrem diferenças marcantes entre os xenólitos quanto aos teores de $\mathrm{TiO}_{2}$ e $\mathrm{Al}_{2} \mathrm{O}_{3}$ sendo que os cristais de $\mathrm{KIxm} 1$ têm os menores teores de $\mathrm{TiO}_{2}$ (até 0,09\%) e maiores de $\mathrm{Al}_{2} \mathrm{O}_{3}$ (até 3,7\%). O gráfico $\mathrm{Al}_{2} \mathrm{O}_{3} \times \mathrm{TiO}_{2}$ (Figura 69a) mostra a correlação negativa entre esses dois óxidos. Baixos teores de $\mathrm{Al}_{2} \mathrm{O}_{3}$ ocorrem nos cristais de $\mathrm{Klxm} 2$ (até $0,9 \%$ ) e $\mathrm{Klxm} 3(0,04 \%$ a $0,6 \%$ ). Uma aparente correlação com tendência positiva é observada entre os xenólitos quanto aos teores de $\mathrm{Al}_{2} \mathrm{O}_{3}$ e $\mathrm{Mg \#} \mathrm{(Figura} \mathrm{69b).} \mathrm{Teores} \mathrm{de} \mathrm{Na}_{2} \mathrm{O}$ mostram valores semelhantes em KIxm1 e KIxm2 (máximo de 1,3\%). 


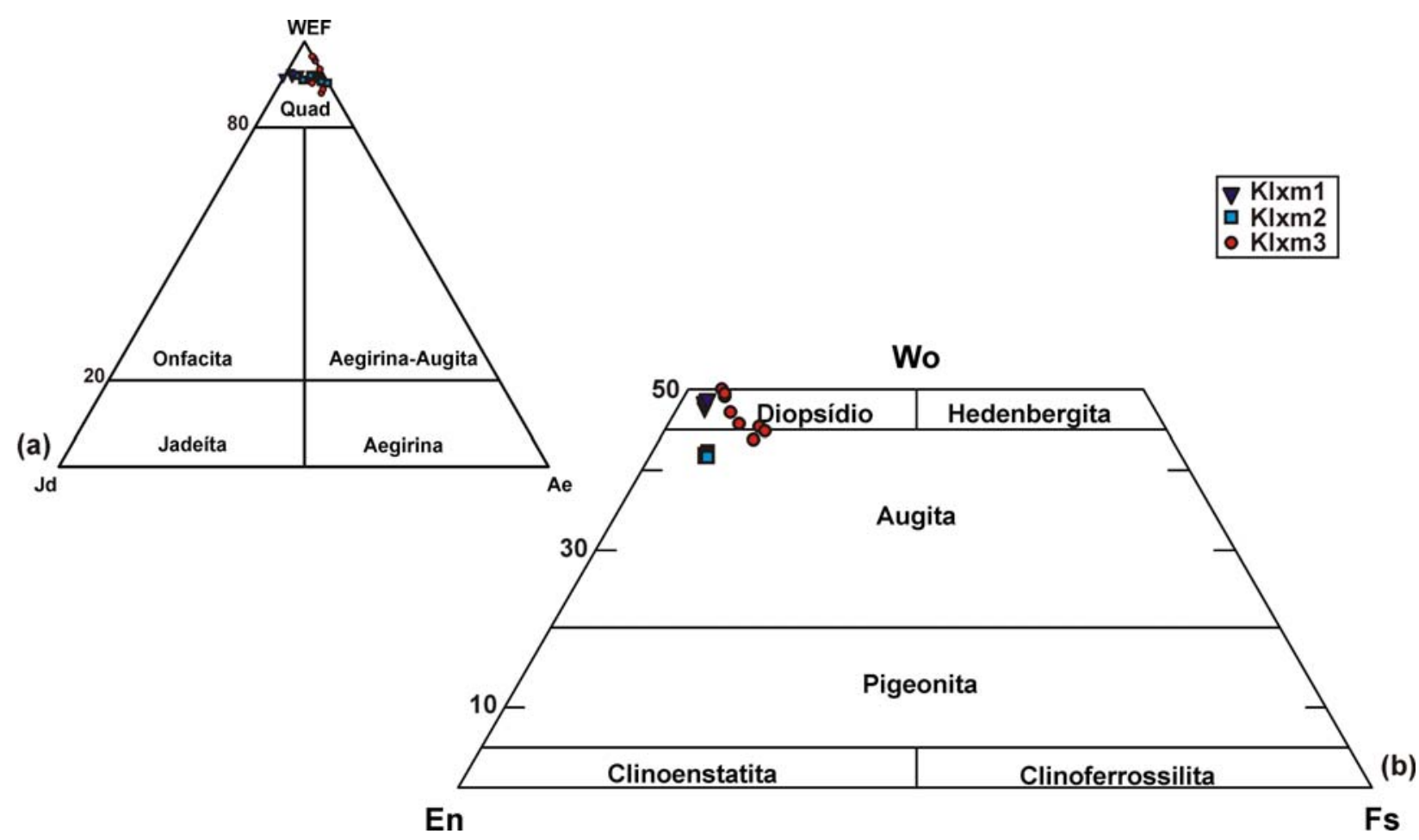

Figura 68: (a) Diagrama de Morimoto (1988) com indicação de que todos os cristais de piroxênio de xenólitos do manto do Kimberlito Limeira 1 devem ser classificados no quadrilátero (Quad). (b) Quadrilátero. Diagrama de Morimoto (1988) com classificação dos cristais de clinopiroxênio.

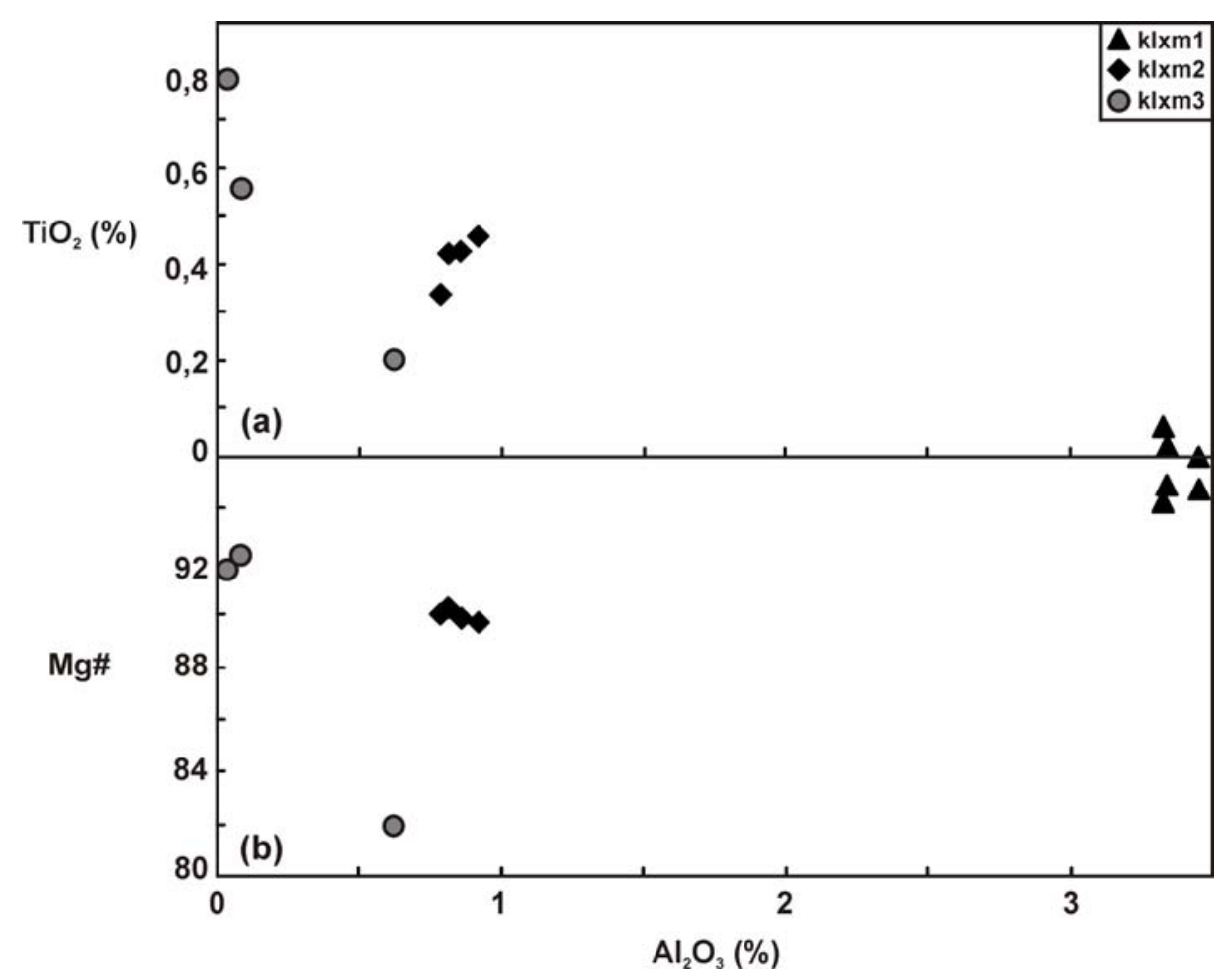

Figura 69: Composições de núcleos de cristais de clinopiroxênio de xenólitos do manto do Kimberlito Limeira 1 mostrando a correlação negativa entre $\mathrm{Al}_{2} \mathrm{O}_{3}$ e $\mathrm{TiO}_{2}$ (a) e a aparente correlação positiva entre $\mathrm{Al}_{2} \mathrm{O}_{3}$ e $\mathrm{Mg \#}(\mathrm{Mg} /(\mathrm{Mg}+\mathrm{Fe}))(\mathrm{b})$. 


\subsubsection{Espinélio}

Foram analisados cristais de espinélios nos xenólitos Klxm1 (grupo 1) e Klxm2 (grupo 2). As análises encontram-se no Anexo 4. $\mathrm{O}$ teor de $\mathrm{Fe}_{2} \mathrm{O}_{3}$ foi calculado por meio da razão $\mathrm{Fe}^{2+} / \mathrm{Fe}^{3+}$ estimada pelo procedimento de Carmichael (1967). As composições foram lançadas na Figura 70. No geral os cristais de Klxm1 apresentam maiores teores de $\mathrm{Al}_{2} \mathrm{O}_{3}$ (39 a 41\%) e $\mathrm{MgO}\left(15\right.$ a 16,8\%) e menores de $\mathrm{Cr}_{2} \mathrm{O}_{3}$ (27,2 a 29,7\%) em relação aos encontrados em Klxm2 (3,5\% de $\mathrm{Al}_{2} \mathrm{O}_{3}$ e 49,8\% de $\left.\mathrm{Cr}_{2} \mathrm{O}_{3}\right)$ e têm portanto menores razões $\mathrm{Cr} /(\mathrm{Cr}+\mathrm{Al})(\mathrm{Cr} \#)$ e menores razões $\mathrm{Fe}^{2+} /\left(\mathrm{Fe}^{2+}+\mathrm{Mg}\right)$ e $\mathrm{Fe}^{3+} /\left(\mathrm{Fe}^{3+}+\mathrm{Al}+\mathrm{Cr}\right)$. O teor de $\mathrm{Fe}_{2} \mathrm{O}_{3}$ calculado é maior em $\mathrm{KIxm} 2$ que também mostrou cerca de $5 \%$ de $\mathrm{TiO}_{2}$. Não forma observados teores significativos deste último óxido em Klxm1.

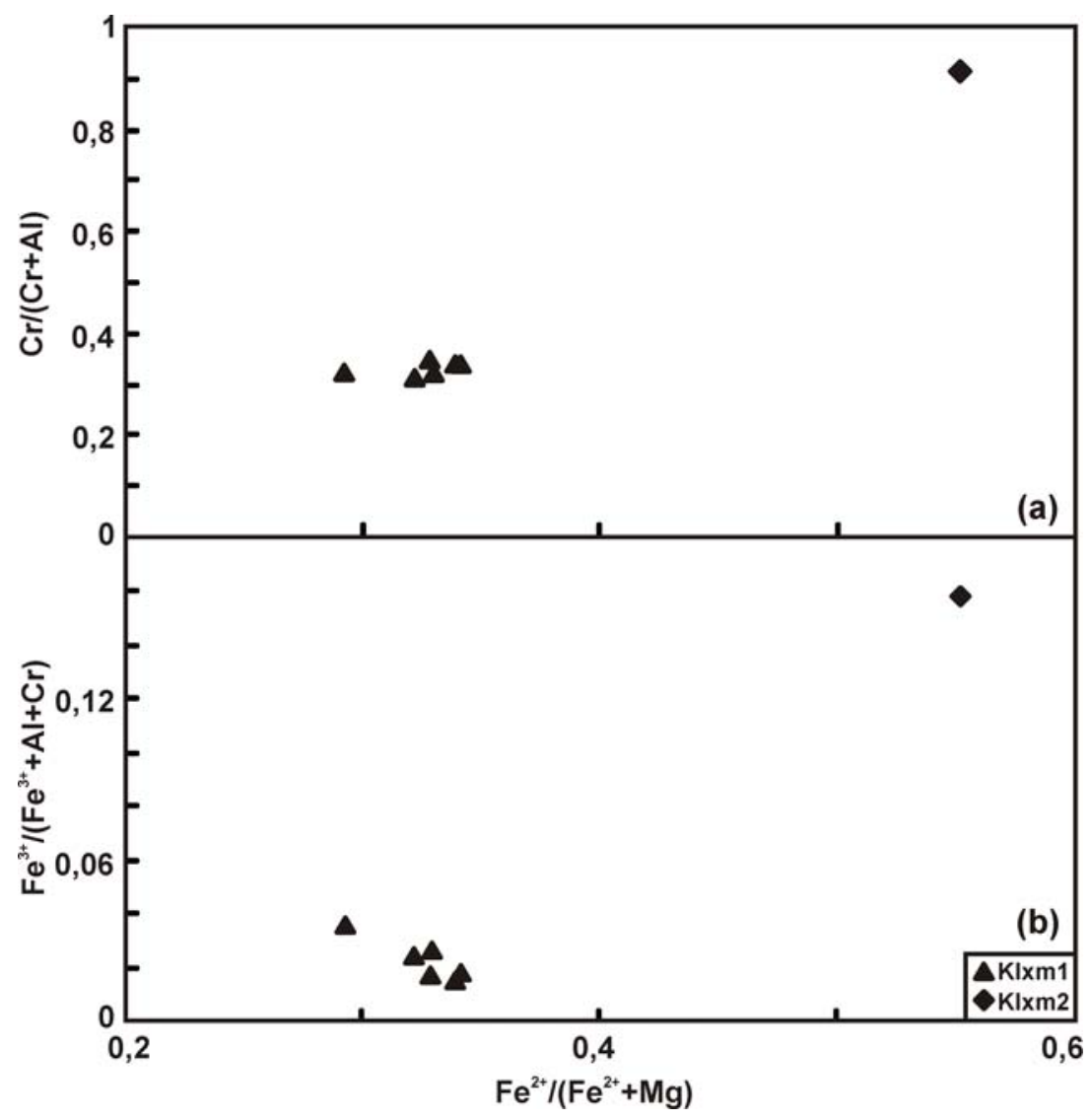

Figura 70: Composições de cristais de espinélio de xenólitos do manto do Kimberlito Limeira 1 com relação entre as razões $\mathrm{Fe}^{2+} /\left(\mathrm{Fe}^{2+}+\mathrm{Mg}\right) \operatorname{com~} \mathrm{Cr} /(\mathrm{Cr}+\mathrm{Al})$ (a) e $\mathrm{Fe}^{3+} /\left(\mathrm{Fe} \mathrm{e}^{3+}+\mathrm{Al}+\mathrm{Cr}\right)$ (b).

O espinélio do xenólito Klxm2 está associado com flogopita e é sempre manteado por mathiasita e/ou ilmenita. O maior valor de $\mathrm{Cr} \#(0,9)$ de $\mathrm{KIxm} 2$ se correlaciona ao baixo teor de $\mathrm{Al}_{2} \mathrm{O}_{3}$ do orto e clinopiroxênio deste xenólito. Tanto Klxm1 como Klxm2 mostram cristais com $\mathrm{Cr} \#$ maior que 0,3 , com valores levemente maiores $(\mathrm{Cr} \# \sim 0,32)$ em Klxm1. Apesar dos dois xenólitos serem classificados modalmente como Iherzolitos, a química mineral pode indicar, segundo os critérios de Fodor et al. (2002), que se tratam de harzburgitos com clinopiroxênio. 
As análises de espinélio obtidas se encaixam dentro do campo composicional delimitado por Barnes \& Roeder (2001) para espinélio de xenólitos mantélicos em kimberlitos (Figura 71).

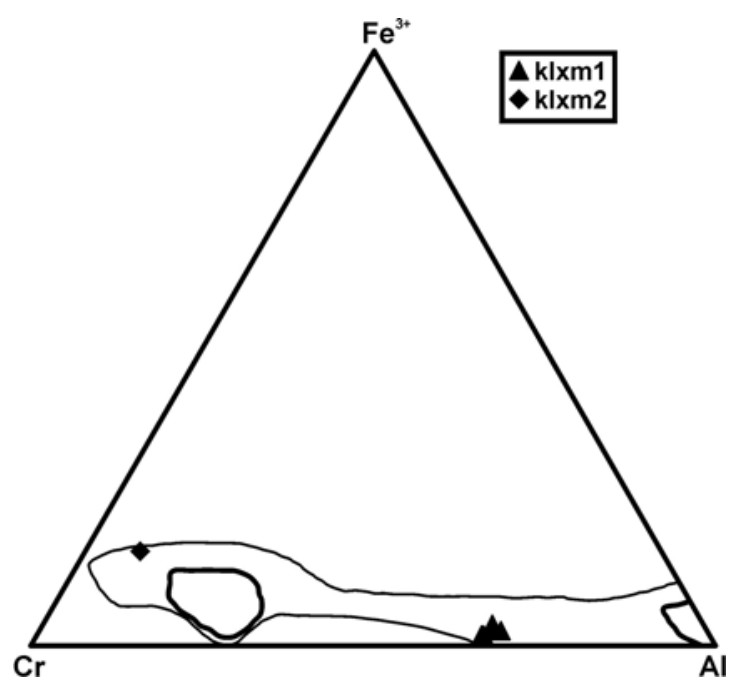

Figura 71: Diagrama ternário com campos definidos por Barnes \& Roeder (2001) para cristais de espinélio em xenólitos de kimberlitos. As linhas mais fortes indicam regiões com maior concentração de análises.

\subsubsection{Fases minerais metassomáticas}

A maior parte dos xenólitos do Kimberlito Limeira 1 apresenta fases minerais notadamente secundárias, metassomáticas, concentradas nos bolsões e interstícios e até representando quase a totalidade do xenólito (e.g. xenólito Klxm3). Essas fases se encontram em desequilíbrio com cristais de olivina, e por vezes ortopiroxênio, e sua composição química evidencia processos de refertilização por elementos incompatíveis (e.g. LILE, HFS). A química dos cristais secundários de clinopiroxênio e de espinélio, quimicamente afetado por processos secundários, já foi previamente discutida. Neste item serão focalizadas as outras fases máficas: flogopita e fases acessórias como titanatos exóticos (mathiasita e priderita) e ilmenita.

\section{Flogopita}

Cristais de flogopita foram analisados nos xenólitos do grupo 2 (Klxm2) e grupo 3 (Klxm3). As análises encontram-se nos Anexo 5. A Figura 72 mostra a relação das análises com alguns membros finais de micas trioctaédricas segundo Rieder et al. (1998). Como indicado no gráfico, os cristais do xenólito Klxm2 apresentam maior Al e menor Fe (11,9 a $12,3 \%$ de $\mathrm{Al}_{2} \mathrm{O}_{3}$ e 4,5 a $5 \%$ de $\mathrm{FeO}_{\mathrm{t}}$ ) em relação a $\mathrm{Klxm} 3$ (9,6 a 10,4\% de $\mathrm{Al}_{2} \mathrm{O}_{3}$ e 6,9 a 9,9\% de $\mathrm{FeO}$ ). Ambos os xenólitos apresentam deficiência na soma do total de cátions tetraédricos ( $\mathrm{Si}+$ $\mathrm{Al}<8$ ). No entanto, a soma de cátions octaédricos dos cristais do xenólito Klxm3 ultrapassa o esperado. Isso pode ocorrer pela superestimativa de $\mathrm{Fe}^{2+}$ nas análises de microssonda devido à presença de $\mathrm{Fe}^{3+}$ nos sítios tetraédricos (Brod et al., 2001). A presença de $\mathrm{Fe}^{3+}$ nos sítios 
tetraédricos está relacionada ao pleocroísmo invertido típico de tetra-ferriflogopita (Brod et al., 2001). No entanto, o pleocroísmo é normal nos cristais estudados do Kimberlito Limeira, o que pode ocorrer por uma concentração insuficiente de $\mathrm{Fe}^{3+}$. O valor do $\mathrm{Mg \#}(\mathrm{Mg} /(\mathrm{Mg}+\mathrm{Fe}))$ é maior nos cristais do xenólito KIxm2 $(0,9)$ em relação aos de $\operatorname{KIxm3}(0,78$ a 0,85).

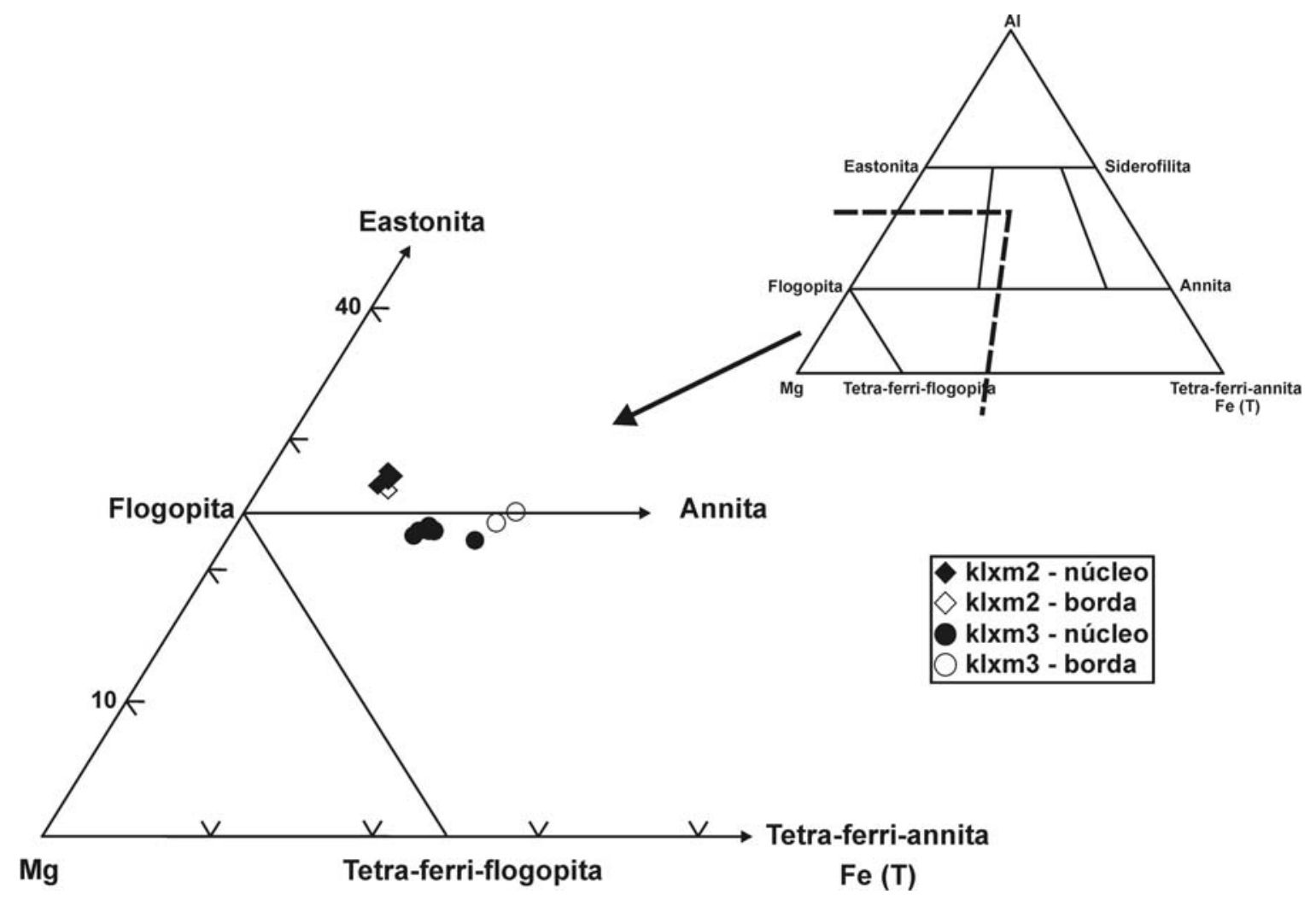

Figura 72: Diagrama com membros finais de micas trioctaédricas segundo Rieder et al. (1998) com análises de flogopita de xenólitos do manto do Kimberlito Limeira 1.

O zoneamento identificado ao microscópio nos cristais do xenólito Klxm3 é composto por núcleo, mais claro, com menor proporção de $\mathrm{TiO}_{2}$ e $\mathrm{FeO}_{\text {total }}$ (e.g. 0,96\% e 7,5\%, respectivamente) e borda, mais escura, com até $3,9 \%$ de $\mathrm{TiO}_{2}$ e $9,9 \%$ de $\mathrm{FeO}_{\text {total. }}$ A presença de inclusões ricas em $\mathrm{Ti}$ (ilmenita, priderita) localizadas no núcleo de cristais de flogopita, coincide com o baixo teor deste elemento nessa região do cristal. $\mathrm{Na}_{2} \mathrm{O}$ (até $0,4 \%$ ) e $\mathrm{BaO}$ (até 0,3\%) ocorrem em maior teor nos cristais de Klxm3.

$\mathrm{Na}$ Figura 73 as análises do xenólito Klxm2 se localizaram dentro do campo composicional de micas secundárias, enquanto as análises do xenólito Klxm3 não estão inseridas em nenhum campo delimitado. Nesse caso, o zoneamento e inclusões ricas em $\mathrm{TiO}_{2}$ na flogopita podem indicar que sua composição não reflete a química original do cristal. Análise de macrocristal de flogopita no Kimberlito Limeira 1 compilada de Costa (1996) se localiza no limite do campo de micas secundárias.

Os cristais de flogopita dos xenólitos estudados apresentam similaridades químicas com micas da suíte MARID e de peridotitos venulados metassomatizados descritos em Dawson 
(1987) principalmente quanto à deficiência em $\mathrm{Al}_{2} \mathrm{O}_{3}$, o maior teor em $\mathrm{TiO}_{2}$ e o $\mathrm{Mg \#}$ da maioria das análises. Segundo Dawson (1987) as micas da suíte MARID reportadas por Dawson \& Smith (1977) apresentam Mg\# (Mg/(Mg+Fe)) variando de 0,82 a 0,88. Matson et al. (1986) ampliaram esse intervalo para 0,81 a 0,92. No geral, micas da suíte MARID apresentam como principais características os altos teores de $\mathrm{FeO}_{\mathrm{t}}, \mathrm{TiO}_{2}, \mathrm{MnO}$ e $\mathrm{Rb}_{2} \mathrm{O}$ e baixos de $\mathrm{Al}_{2} \mathrm{O}_{3}, \mathrm{Cr}_{2} \mathrm{O}_{3}$, $\mathrm{MgO}, \mathrm{NiO}$ e $\mathrm{BaO}$ (Dawson, 1987). Deficiência na soma Si + Al nos sítios tetraédricos de micas e anfibólios da suíte MARID também é citada por Dawson (1987). Ainda segundo este autor, o intervalo de composição para os óxidos maiores de micas de peridotitos venulados metassomatizados se sobrepõem aos das micas da suíte MARID, porém os peridotitos venulados tendem a apresentar maiores $\mathrm{Mg \# ,} \mathrm{TiO}_{2}, \mathrm{Al}_{2} \mathrm{O}_{3}$ e $\mathrm{Cr}_{2} \mathrm{O}_{3}$.

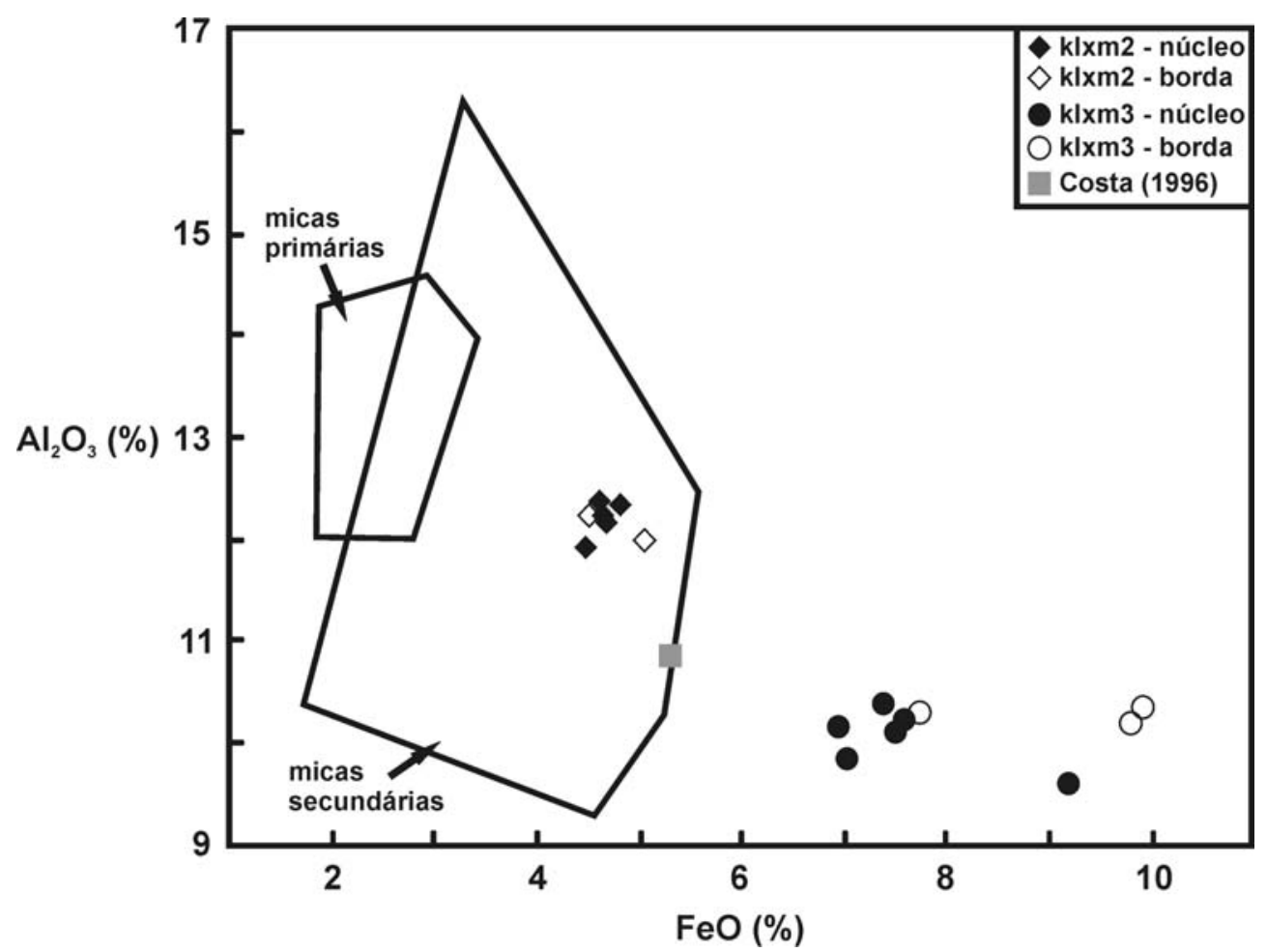

Figura 73: Diagrama $\mathrm{FeO} \times \mathrm{Al}_{2} \mathrm{O}_{3}$ com campos composicionais de micas primárias e secundárias de xenólitos mantélicos com análises de cristais dos xenólitos do manto do Kimberlito Limeira 1. Costa (1996) refere-se a macrocristal de flogopita do kimberlito Limeira 1. Modificado de Mitchell (1995).

\section{IImenita}

Cristais de ilmenita foram identificados através de estudo ao microscópio de luz refletida, imagens BSE e análises EDS e WDS em microssonda eletrônica. As análises encontram-se no Anexo 6. Os cristais ocorrem nos xenólitos dos grupos 2 (Klxm2) e 3 (Klxm3), muitas vezes associados com os titanatos exóticos (mathiasita e priderita). Alguns dos pontos analisados nesse mineral encontram-se destacados nas imagens BSE (Figuras 74, 76, 80 e 81). No xenólito KIxm2 cristais de ilmenita foram identificados apenas próximo ao contato com 
o kimberlito. Imagens e análises EDS mostraram lamelas de exsolução de provável cromita, muito finas, paralelas aos planos (0001) (Figura 74). Exsoluções paralelas a (0001) são características de intercrescimentos de magnetita em ilmenita (Danchin \& D’Orey, 1972). Exsolução de Cr-espinélio em ilmenita foi descrita pela primeira vez por Danchin \& D'Orey (1972), sendo considerada uma feição rara em cristais de ilmenita em kimberlitos.

A ilmenita dos dois xenólitos é magnesiana (Mg-ilmenita com mais de $8 \%$ em $\mathrm{MgO}$ ). A ilmenita de $\mathrm{KIxm} 2$ mostra teores de $\mathrm{Cr}_{2} \mathrm{O}_{3}$ (8,6 a 9,2\%) e $\mathrm{MgO}(12$ a 13,4\%) significativamente maiores em relação a $\mathrm{Klxm} 3\left(0,5\right.$ a 1,8\% de $\mathrm{Cr}_{2} \mathrm{O}_{3}$ e 8,4 a 9,8\% de $\left.\mathrm{MgO}\right)$, o que também se reflete na abundância de lamelas de exsolução de cromita. Assim como para os outros minerais (clinopiroxênio, flogopita) a ilmenita do xenólito $\mathrm{Klxm} 3$ também é mais rica em $\mathrm{FeO}_{\mathrm{t}}$ (36,9 a 38,2\%) e apresenta menor proporção de $\mathrm{Al}_{2} \mathrm{O}_{3}$ (máximo de $0,06 \%$ ). Macrocristais de ilmenita do kimberlito Limeira 1 analisados por Costa (1996) também são magnesianos, mostrando em média $12 \%$ de $\mathrm{MgO}$ e $5 \%$ de $\mathrm{Cr}_{2} \mathrm{O}_{3}$.

$\mathrm{O}$ baixo teor de $\mathrm{Al}_{2} \mathrm{O}_{3}$ dos cristais do xenólito $\mathrm{Klxm} 3$ apresenta similaridade com os teores de $\mathrm{Al}_{2} \mathrm{O}_{3}$ de ilmenitas da suíte MARID (até 0,2\%) e de peridotitos venulados metassomatizados de Bultfontein (África do Sul) (Dawson, 1987).

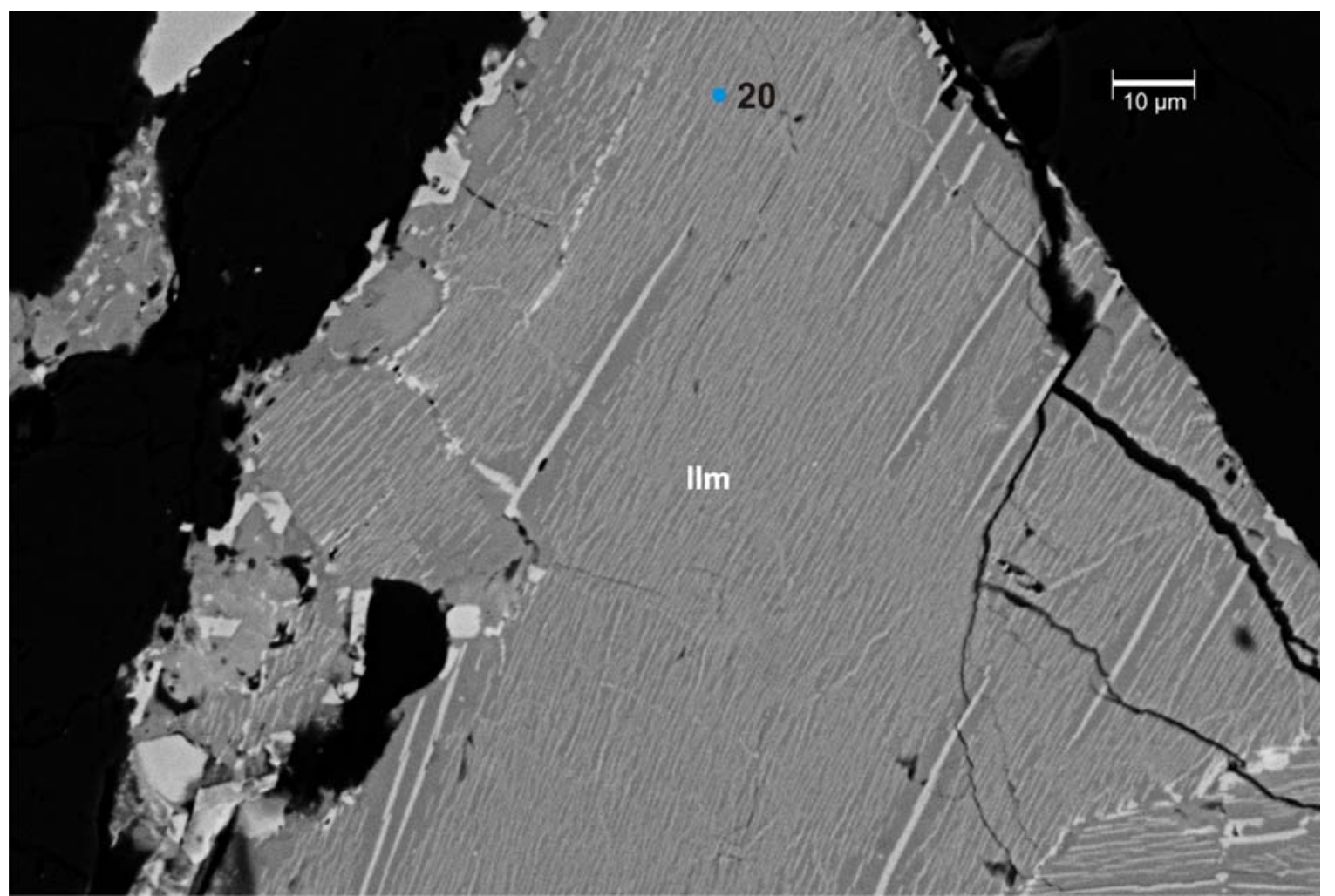

Figura 74: Detalhe de cristal de ilmenita com lamelas de cromita (mais claras). Xenólito Klxm2. 


\section{Mathiasita}

Cristais de mathiasita foram encontrados no xenólito Klxm2 envolvendo todos os cristais analisados de cromita (Figura 75) e ilmenita (Figura 76) presentes nos bolsões com clinopiroxênio e flogopita. Esses cristais foram identificados através de microscopia de luz refletida, imagens de elétrons retroespalhados (BSE) em microscópio eletrônico de varredura e análises por microssonda eletrônica. As análises encontram-se no Anexo 7 e são correspondentes aos números indicados nas imagens.

Mathiasita é um mineral opaco da série crichtonítica $\left(\mathrm{AM}_{21} \mathrm{O}_{38}\right)$, caracterizada por predominância de cátions específicos com alto raio iônico no sítio maior $\mathrm{A}$ (Ba: lindsleyita, K: mathiasita, Sr: crichtonita, $\mathrm{Na}$ : landauita, $\mathrm{Pb}$ : senaita, Ca: loveringita e U+ETR: davidita) e por cátions menores no sítio M (principalmente Ti, Cr, Fe, Mg, Zr e Nb) (Haggerty et al., 1983). Mathiasita foi originalmente identificada em peridotitos metassomatizados e concentrados de minerais de kimberlitos da África do Sul (De Beers, Bultifontein, Kolonkwanen e Jagersfontein) (e.g. Haggerty, 1975; Haggerty et al.,1983). Encontra-se associada caracteristicamente com flogopita, diopsídio, K-richterita, $\mathrm{Nb}-\mathrm{Cr}$ rutilo, $\mathrm{Mg}-\mathrm{Cr}-\mathrm{Nb}$ ilmenita e $\mathrm{Mg}-\mathrm{Cr}$ espinélio. A granada é tipicamente ausente (Haggerty et al., 1983). A mathiasita pode apresentar solução sólida com outros membros da série. No entanto, existem evidências de apenas algum grau de solubilidade entre mathiasita e lindsleyita (Haggerty et al., 1983). 
(a)

(b)
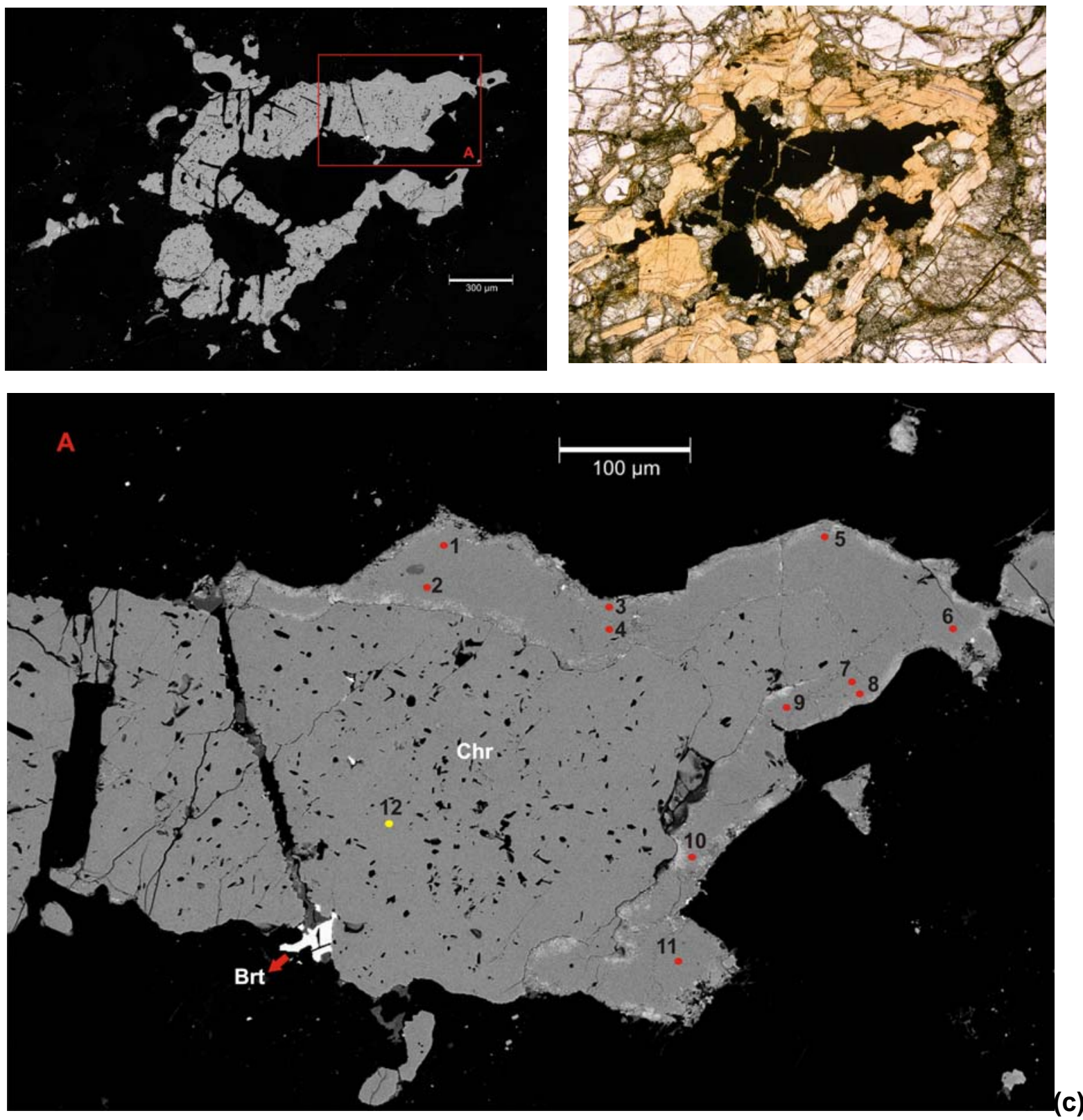

Figura 75: Imagens BSE (a e c) mostrando cristal de cromita (Chr) parcialmente manteado por mathiasita (área com tons de cinza similares, mas menos "porosa", na qual estão assinalados pontos de análise em vermelho). Pequeno cristal de alto número atômico médio (branco) na terminação da fratura corresponde a barita (Brt). A imagem no microscópio de luz transmitida é mostrada em (b). 

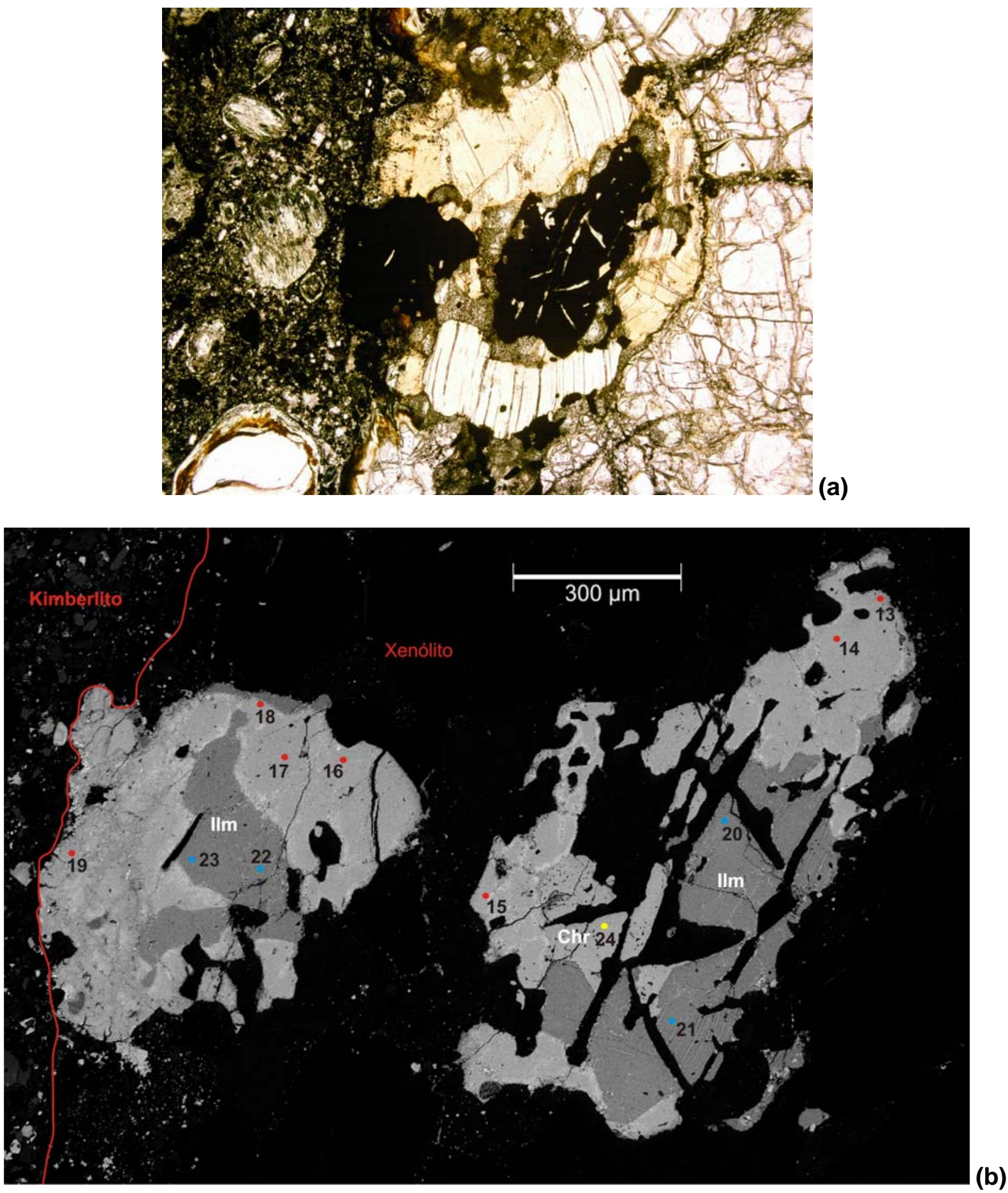

Figura 76: Imagem no microscópio de luz transmitida (a) e imagem BSE (b) mostrando relação entre cromita (Chr), Ilmenita (IIm) e mathiasita (pontos em vermelho) localizados próximo ao contato do xenólito com kimberlito.

As análises WDS apresentam de 54,9 a 60,4\% de $\mathrm{TiO}_{2}, 5,2$ a $6,7 \%$ de $\mathrm{ZrO}_{2}, 0,7$ e 0,8\% de $\mathrm{Al}_{2} \mathrm{O}_{3}$ e 13,5 a $15,2 \%$ de $\mathrm{Cr}_{2} \mathrm{O}_{3}$. Maiores variações são identificadas principalmente nos elementos do sítio A como $\mathrm{Ca}(1 \mathrm{a} 4,8 \%$ de $\mathrm{CaO})$, $\mathrm{Ba}(0,4$ a 2,6\% de $\mathrm{BaO})$ e $\mathrm{K}(0,8$ a $7,4 \%$ de $\mathrm{K}_{2} \mathrm{O}$ ), que mostram relação inversamente proporcional com o $\mathrm{Fe}$, como indicado no gráfico $\mathrm{K}(\mathrm{A}) \times \mathrm{Fe}(\mathrm{M})$ (Figura 77). As análises pertencentes ao grupo principal, circundado no gráfico, apresentam excesso de cátions nos sítios A e M. O restante das análises está localizado 
próximo à borda dos cristais e também apresentam excesso de cátions no sítio $\mathrm{A}$ e por vezes falta no sítio M. Alterações no total de cátions também foram observadas em análises de Haggerty et al. (1983), que as atribuíram tentativamente à solubilidade de outros componentes na estrutura e à possibilidade de que nem todos os ETR estejam alocados no sítio A.

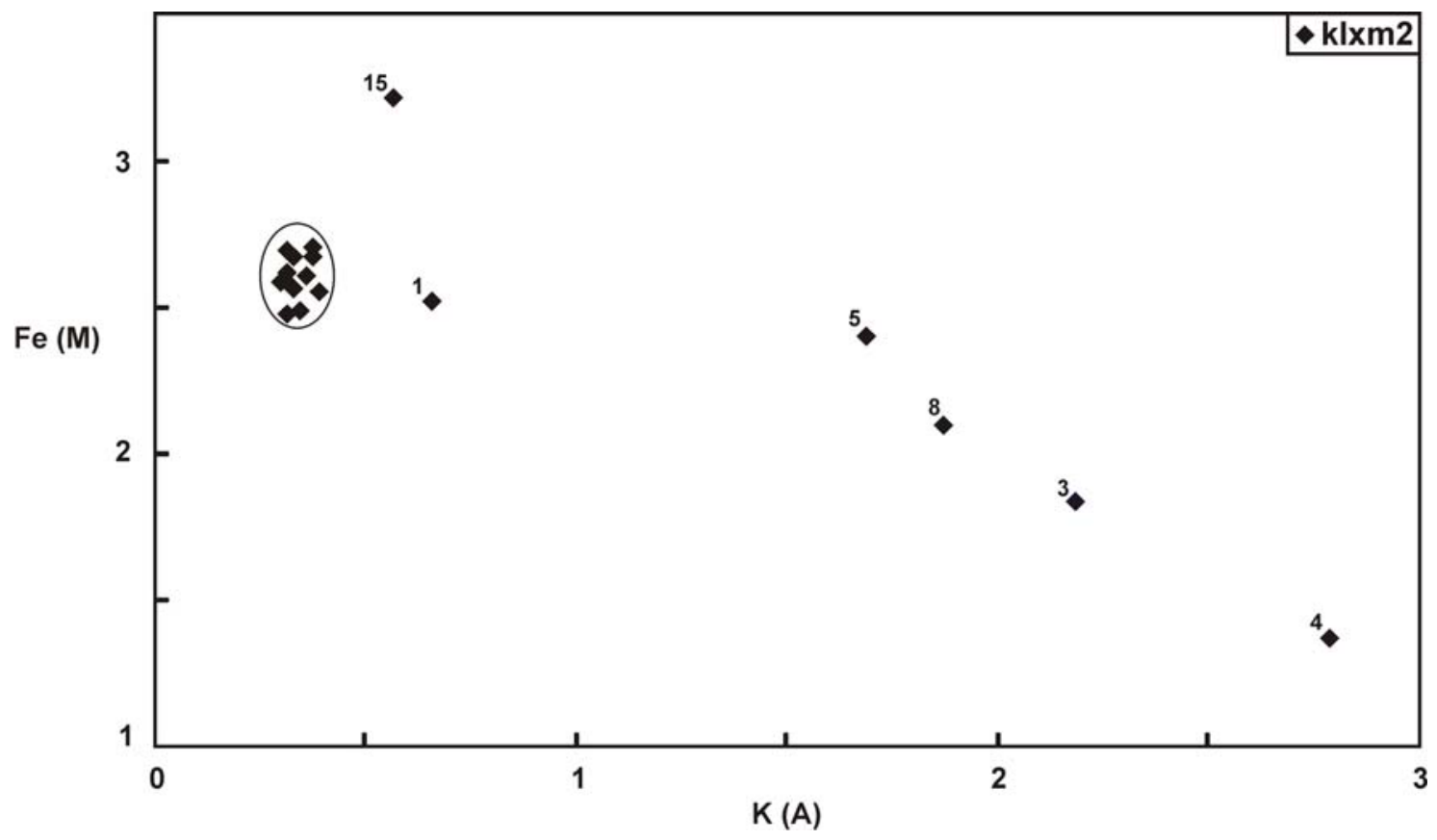

Figura 77: $K(A) \times F e(M)$ (proporções catiônicas) em cristais de mathiasita dos xenólitos do Kimberlito Limeira 1. O grupo principal de análises encontra-se circundado.

A Figura 78 mostra diagrama com as análises de lindsleyita $(\mathrm{Ba})$ e mathiasita $(\mathrm{K})$ de kimberlitos da África do Sul e a extensão da solução sólida com os membros de $\mathrm{Ca}, \mathrm{ETR}, \mathrm{Pb}$, $\mathrm{Sr}$ e $\mathrm{Na}$. Os minerais dos xenólitos do Kimberlito Limeira se assemelham às análises de mathiasita de Jagersfontein (Haggerty et al., 1983).

Os trends de reação de óxidos do manto superior segundo Haggerty (1995), mostrados na Figura 79, são definidos a partir da adição metassomática de elementos incompatíveis ( $Z$ r, $\mathrm{Ti}, \mathrm{Nb}$ e ETR) em espinélio previamente empobrecido. O grupo principal de análises se encaixa dentro do campo estabelecido para lindsleyita-mathiasita.

Segundo Haggerty et al. (1983), lindsleyita e mathiasita estão estritamente relacionadas ao metassomatismo no manto superior. Foley et al. (1994) através de investigações experimentais atribuíram um campo de estabilidade para esses minerais e priderita, de 3,5 a 5 GPa. Ambos os trabalhos salientam a importância desses minerais para o estudo da gênese de magmas alcalinos, já que são considerados como principais repositários de elementos altamente incompatíveis no manto.

Os cristais estudados neste trabalho apresentam evidências de geração por interação de fluidos/fundidos ricos em elementos incompatíveis (HFS, ETR) com espinélio (cromita) bastante empobrecido como evidenciado por seu alto $\mathrm{Cr}$. 


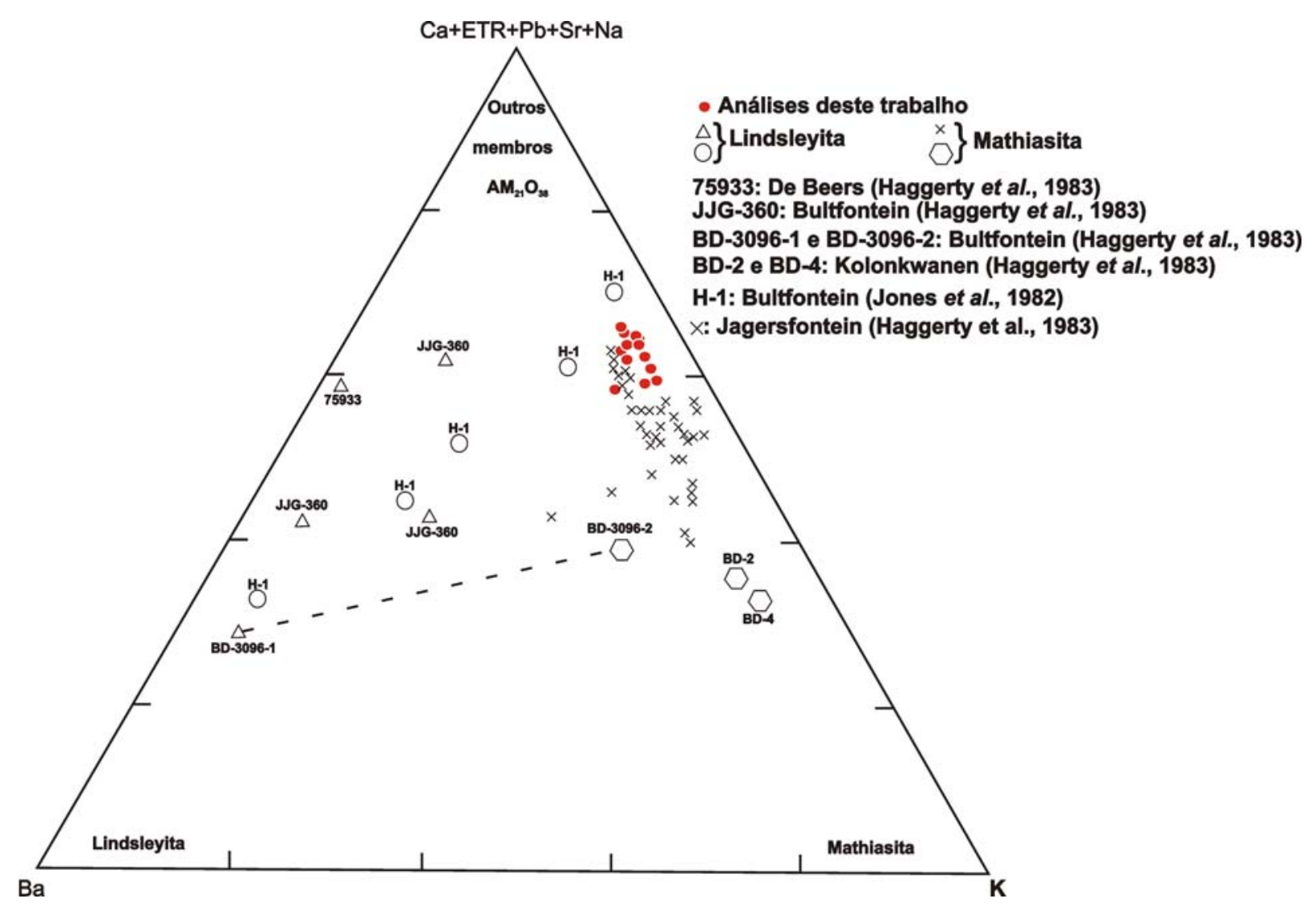

Figura 78: Diagrama ternário com análises obtidas neste trabalho (pontos em vermelho) em comparação com análises de xenólitos em kimberlitos da África do Sul. Diagrama modificado de Haggerty et al. (1983). Pb não foi analisado.

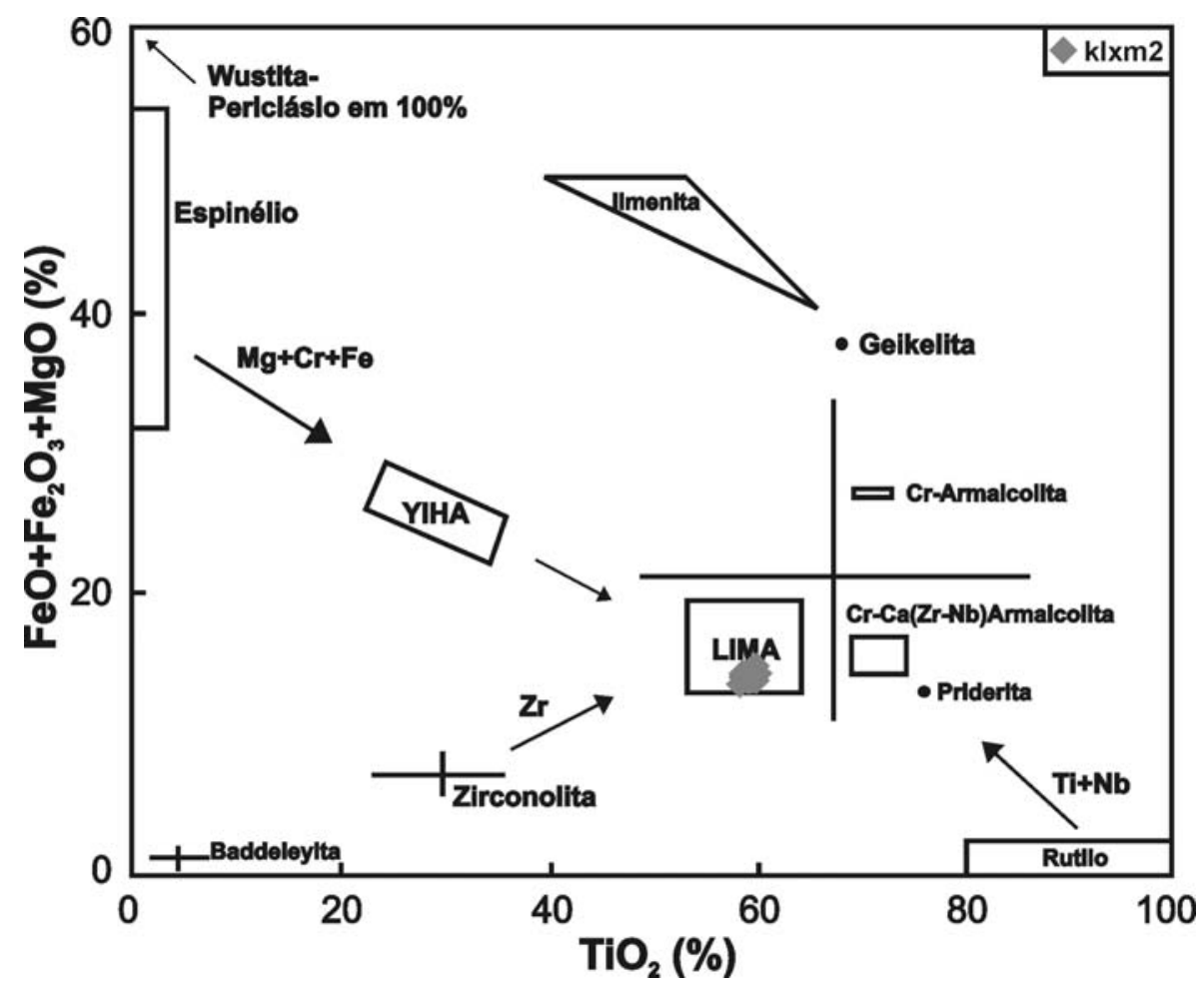

Figura 79: Dados composicionais de mathiasita do xenólito KIxm2 projetados no diagrama de Haggerty (1995). O diagrama ressalta os trends de reação de outros óxidos exóticos no manto superior derivados de espinélio previamente empobrecido. Foi considerado $\mathrm{FeO}_{\text {total }}$ no lugar de $\mathrm{FeO}+\mathrm{Fe}_{2} \mathrm{O}_{3}$. 


\section{Priderita}

Cristais de priderita foram identificados no xenólito Klxm3, onde ocorrem na forma de pequenas lamelas $(\sim 0,03 \mathrm{~mm})$ de cor vermelho escuro (semelhante a rutilo) no interior de cristais de ilmenita (Figuras 80 e 81). Os resultados das análises encontram-se no Anexo 8; os números das análises são indicados nas imagens.

A priderita foi descrita pela primeira vez por Norrish (1951) sendo comumente encontrada em leucita lamproitos (Harte, 1987) e também em nódulos como os de Prairie Creek no Alaska. É um titanato do grupo da hollandita com fórmula estrutural $A_{1,5} M_{8} O_{16}$ onde o sítio maior A é ocupado principalmente por $\mathrm{Ba}, \mathrm{K}$ e concentrações menores de $\mathrm{Sr}, \mathrm{Ca}, \mathrm{Na}$ e ETR. O sítio M é ocupado principalmente por Ti e Fe, sendo este último em concentração bem menor que o primeiro (Foley et al., 1994). No Brasil, existe a descrição de ocorrência de priderita em flogopititos do Complexo Carbonatítico de Catalão (Gaspar et al., 1994).

As análises WDS apresentaram como elementos principais do sítio M: Ti (69,3 a 91,6\% de $\left.\mathrm{TiO}_{2}\right), \mathrm{Cr}\left(1\right.$ a $2,6 \%$ de $\left.\mathrm{Cr}_{2} \mathrm{O}_{3}\right), \mathrm{Mg}(0,5$ a $2 \%$ de $\mathrm{MgO}), \mathrm{Fe}(1 \mathrm{a} 10 \%$ de $\mathrm{FeOt}), \mathrm{Nb}(1,5$ a $4 \%$ de $\left.\mathrm{Nb}_{2} \mathrm{O}_{5}\right)$ e $\mathrm{Zr}\left(0,10\right.$ a $0,5 \%$ de $\left.\mathrm{ZrO}_{2}\right)$. No sítio $\mathrm{A}: \mathrm{K}\left(2,4\right.$ a $12 \%$ de $\left.\mathrm{K}_{2} \mathrm{O}\right)$, Ca (0 a 1,7\% de $\left.\mathrm{CaO}\right)$, $\mathrm{Na}\left(0\right.$ a $0,57 \%$ de $\left.\mathrm{Na}_{2} \mathrm{O}\right)$, $\mathrm{Ba}(0,2$ a $1 \%$ de $\mathrm{BaO})$ e $\mathrm{Sr}(0$ a $0,3 \%$ de $\mathrm{SrO})$. Relação inversamente proporcional é encontrada entre $\mathrm{Ti}$ e Fe (Figura 82), possivelmente resultado de intercrescimento com rutilo que é mais evidente nas análises 32 a 35 com os mais altos teores de $\mathrm{TiO}_{2}$ (e.g. 91,6\%) e menores de $\mathrm{K}_{2} \mathrm{O}$ (e.g. 2,4\%) e FeOt (e.g. 0,5\%). Esses pontos de análise localizam-se em regiões mais escuras, próximo aos pontos de análise de priderita, na imagem BSE (Figura 81). O diagrama com os trends de reação de óxidos no manto superior (Figura 83) mostra análises com menor $\mathrm{TiO}_{2}$ e maior $\mathrm{FeO}_{\mathrm{t}}$ próximo ao ponto da priderita, enquanto as análises 32 a 35 estão mais próximas ou até mesmo dentro (ponto 32 ) do campo do rutilo. 
(a)

(b)
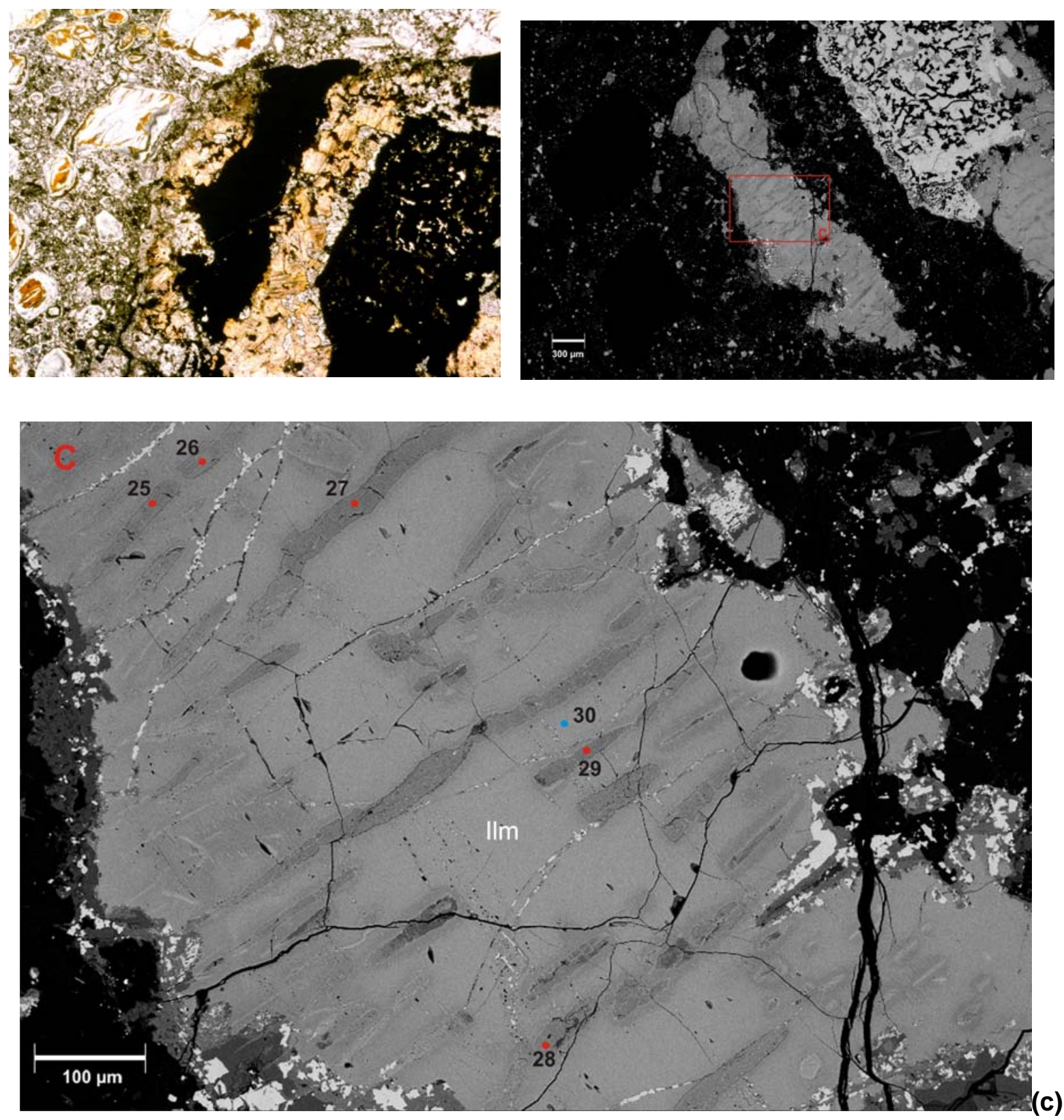

Figura 80: Imagem em microscópio de luz transmitida de cristal de ilmenita ((a) centro); imagem BSE mostrando cristal de ilmenita com priderita na forma de lamelas (b) e detalhe das lamelas de priderita (pontos em vermelho) (c). 
(a)

(b)
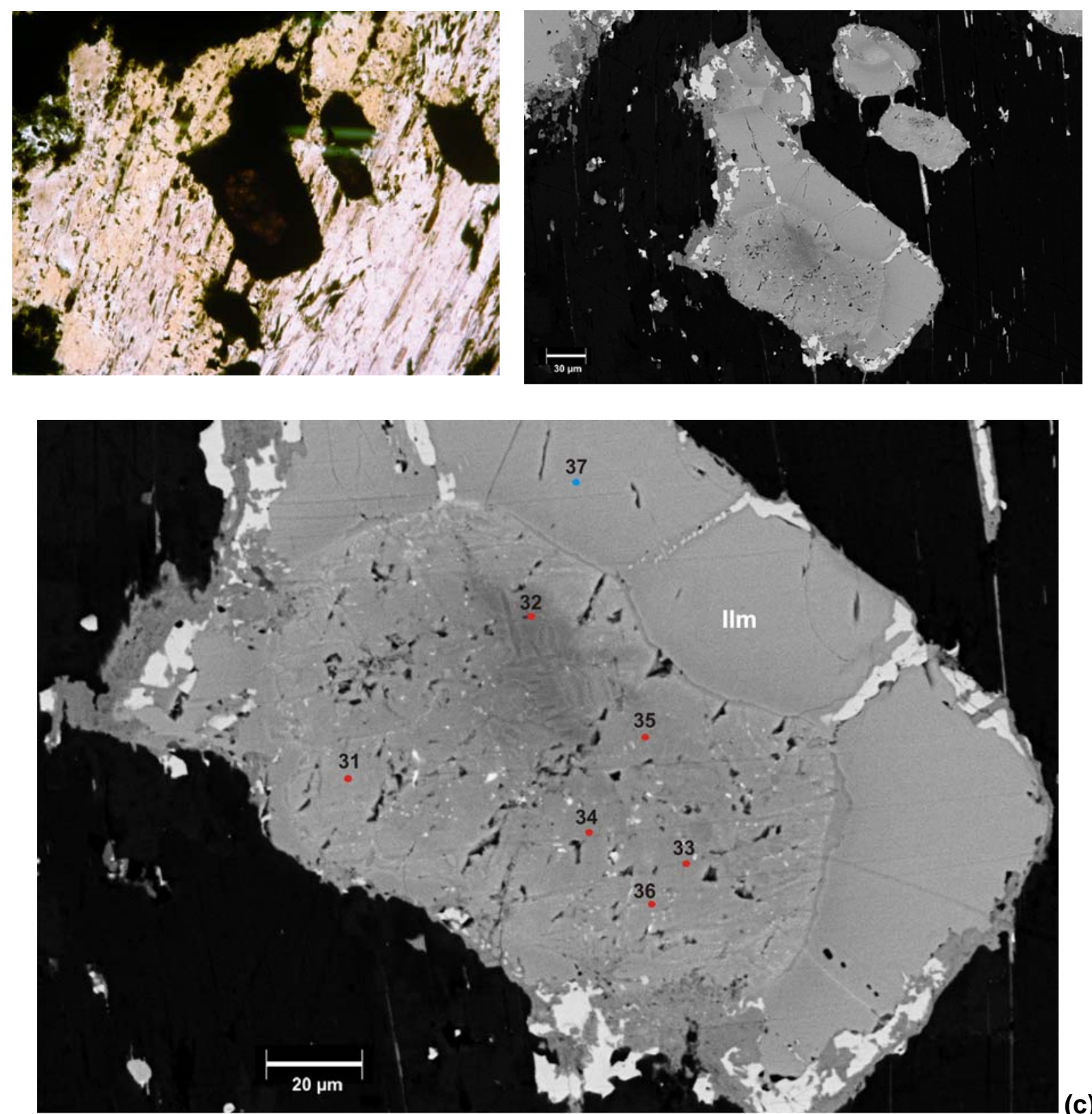

(c)

Figura 81: Imagem no microscópio de luz transmitida de priderita manteada por ilmenita (a); imagem BSE de priderita (pontos 31 e 36) manteada por ilmenita (IIm ponto 37) (b e c). Pontos 32 a 35 (região cinza escuro) apresentam intercrescimento com rutilo. 


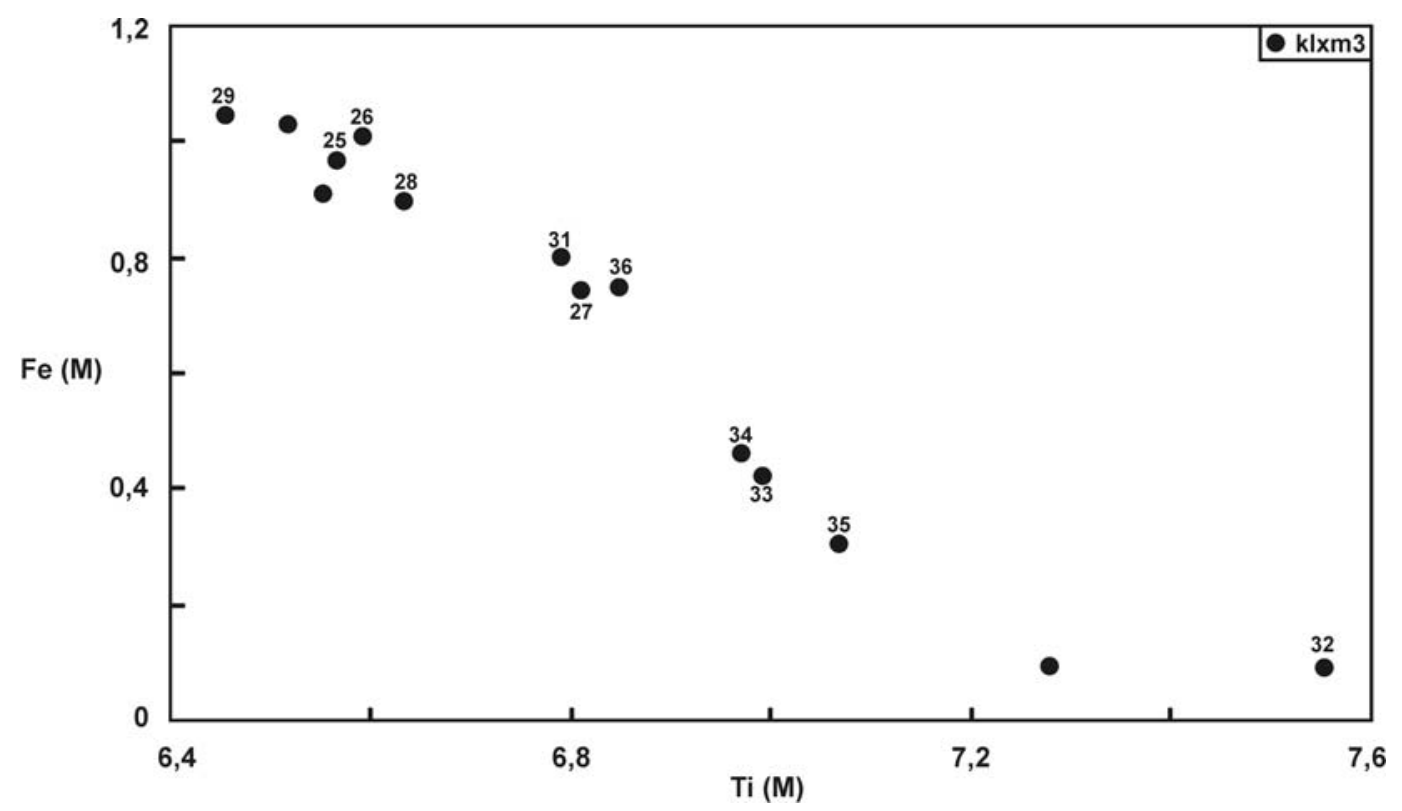

Figura 82: Relação inversamente proporcional entre Ti (M) e Fe (M) com indicação dos pontos analisados.

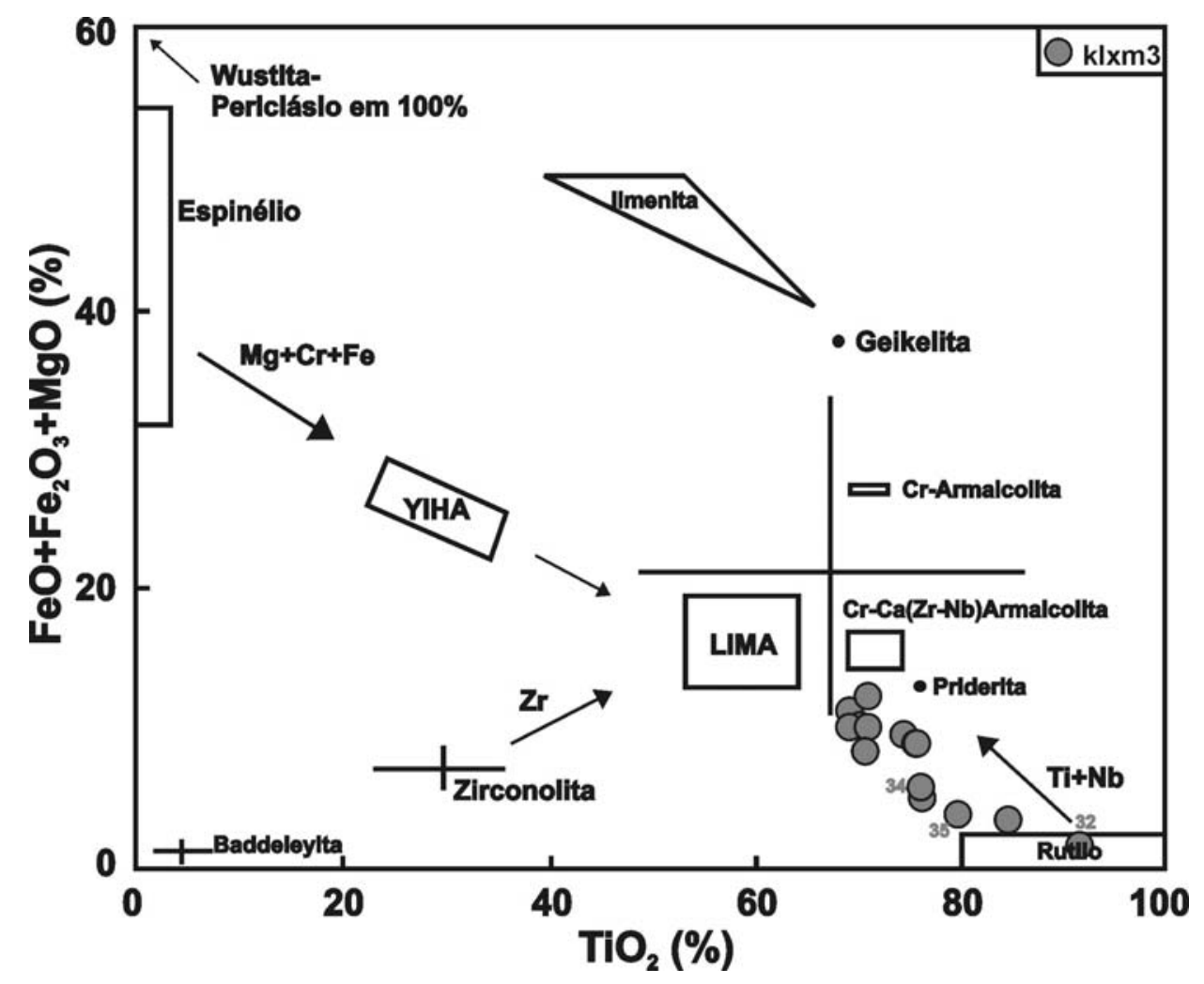

Figura 83: Dados composicionais de priderita do xenólito Klxm3 projetados no diagrama de Haggerty (1995). O diagrama ressalta os trends de reação de outros óxidos exóticos no manto superior derivados de espinélio previamente empobrecido. Foi considerado $\mathrm{FeO}_{\text {total }}$ no lugar de $\mathrm{FeO}+\mathrm{Fe}_{2} \mathrm{O}_{3}$ 


\section{Outras fases acessórias}

Outras fases máficas acessórias ocorrem nos xenólitos Klxm2 e Klxm3, porém ainda não puderam ser adequadamente definidas e analisadas dadas as suas pequenas dimensões. No xenólito Klxm2, essas fases estão localizadas no contato xenólito-kimberlito próximo à borda da mathiasita (Figura 76). As análises (Anexo 9) diferenciadas (pontos 18 e 19, Figura 76) parecem representar uma mistura com o titanato, onde os teores de $\mathrm{TiO}_{2}$ e $\mathrm{ZrO}_{2}$ são semelhantes aos da mathiasita, porém com teores muito maiores de $\mathrm{CaO}$ (7 e 21,5\%). Perovskita é um mineral que provavelmente está misturado com o titanato. No xenólito Klxm3 a presença de perovskita parece ser ainda mais evidente na borda de alguns cristais de ilmenita dentro do xenólito. Essas análises apresentam até $50 \%$ de $\mathrm{TiO}_{2}$, até $34 \%$ de $\mathrm{CaO}$ e até $3 \%$ de SrO. Costa (1996) cita a presença de perovskita na matriz e na borda de macrocristais de ilmenita do kimberlito Limeira 1. Esta análise encontra-se no Anexo 9.

\subsection{Análises de elementos traços por LA-ICPMS}

Foram analisados cristais de olivina, ortopiroxênio e clinopiroxênio dos xenólitos dos grupos 1 (KIxm1), 2 (KIm2) e 3 (KIxm3) por LA-ICPMS, selecionados por meio da análise das texturas e da química de elementos maiores por microssonda eletrônica.

\section{Olivina}

Os resultados obtidos nas análises de elementos traços em olivina são apresentados no Anexo 11. Foram analisados cristais apenas no xenólito Klxm1. Boa parte dos LILE (e.g. Rb, $\mathrm{Ba}, \mathrm{Sr}, \mathrm{ETRL}$ ) e alguns elementos HFS (e.g. Ti, Zr) apresentam teores abaixo do limite de detecção (l.d.). Entre os ETR a maior concentração foi obtida para Nd (0,04 ppm).

Os teores mais significativos são encontrados para $\mathrm{P}, \mathrm{Mn}, \mathrm{Cr}$, Co, Ni e Zn. P apresenta máximo de 53 ppm, valor por vezes maior que a concentração presente em ortopiroxênio e clinopiroxênio desse mesmo xenólito. As razões $C_{o} / C_{o p x}$ (concentração na olivina $/$ concentração no ortopiroxênio) do $\mathrm{P}$ variam de 0,9 a 1,9 e $C_{o} / C_{c p x}$ de 0,9 a 1,6. Ti apresenta somente concentrações abaixo do limite de detecção o que está em conformidade com os teores muito baixos de $\mathrm{TiO}_{2}$ obtidos pela microssonda eletrônica para olivina, orto e clinopiroxênios desse xenólito. Mn, Ni, Zn e Cr apresentam teores máximos de 953 ppm, 3240 ppm, 24 ppm e 7 ppm, respectivamente. 


\section{Ortopiroxênio}

Cristais de ortopiroxênio dos xenólitos Klxm1 e Klxm2 foram analisados. Os resultados das análises encontram-se no Anexo 12. Os cristais dos dois xenólitos mostram diferenças significativas quanto à química de traços, de modo análogo ao observado para a química de elementos maiores e menores.

O ortopiroxênio de Klxm1 apresenta baixos teores em LILE, alguns deles abaixo ou muito próximos do limite de detecção (e.g. ETR). Dentre os ETR, maior concentração foi obtida para $\mathrm{Yb}(0,07 \mathrm{ppm})$. O ortopiroxênio deste xenólito também apresenta teores muito baixos de HFS. Ti e Zr, por exemplo, apresentam máximos de 88 ppm e 0,035 ppm, respectivamente, contra 1100 ppm e 1,9 ppm no xenólito Klxm2, que apresenta maior concentração para diversos outros elementos, incluindo alguns ETR (e.g. 0,6 ppm de Ce), Y (até 0,3 ppm) e Ni (até $834 \mathrm{ppm}$ ). Inclusões ou zoneamentos envolvendo Ba e $\mathrm{Sr}$ foram por vezes identificados pela observação da variação da forma dos picos dos perfis analíticos. No entanto, na ausência dessas feições esses dois elementos também apresentam maior concentração no xenólito KIxm2.

Os dois cristais analisados de Klxm2 não estão relacionados aos bolsões ricos em flogopita dessa amostra, mas apresentam feições distintas. O primeiro cristal apresenta algumas inclusões ou vênulas de infiltração com flogopita e clinopiroxênio anédricos (Figura 43), enquanto o segundo está em desequilíbrio com cristal maior de clinopiroxênio repleto de inclusões de flogopita que parecem ter sido formados por uma reação com o ortopiroxênio (Figura 44). Os dois mostraram diferenças quanto à concentração de alguns elementos traços. O cristal apresentado na Figura 44 tem maior concentração em ETR (0,3 ppm de La) e também tem inclusões ou zoneamentos envolvendo Ba (até 6 ppm) e Sr (até 6 ppm).

\section{Clinopiroxênio}

Foram analisados cristais de clinopiroxênio nos xenólitos Klxm1, Klxm2 e Klxm3. As análises encontram-se no Anexo 13. O clinopiroxênio é o principal hospedeiro de LILE e HFS, enquanto os elementos $\mathrm{Mn}$, Co e $\mathrm{Ni}$ se concentram preferencialmente em olivina e ortopiroxênio. Inclusões ou zoneamentos químicos envolvendo principalmente $\mathrm{Ba}$, $\mathrm{Sr}$ e por vezes $\mathrm{Nb}$ e ETRL foram identificados nos xenólitos por meio do exame da variação dos picos nos perfis analíticos no software Glitter.

Os cristais dos xenólitos Klxm2 e Klxm3, relacionados a texturas secundárias, são os mais enriquecidos em elementos incompatíveis como ETRL (e.g. até 8 ppm de La em KIxm2 e até 19 ppm em Klxm3) e HFS (e.g. até 100 ppm de Zr em Klxm2 e até 178 ppm em Klxm3). Esse enriquecimento é mais pronunciado em Klxm3. 
Os cristais de KIxm1 apresentam menores concentrações de ETR (e.g. até 1,3 ppm de La) e assim como os cristais de ortopiroxênio também apresentam notável empobrecimento de alguns HFS (e.g. até $241 \mathrm{ppm}$ de Ti e até 0,2 ppm de $\mathrm{Zr}$ ). Y também ocorre em baixa concentração (até 2,3 pmm contra máximo de 7 ppm de Klxm2).

Razões LILE/HFS representadas pelos pares La/Nb e La/Zr (Figura 84) mostram diferentes valores para os xenólitos. O xenólito Klxm1 apresenta maiores razões La/Zr, devido ao empobrecimento já citado de $\mathrm{Zr}$, e razões La/Nb próximas de 2, enquanto Klxm2 e Klxm3 apresentam justamente o contrário, baixíssimas razões La/Zr e altas razões La/Nb.

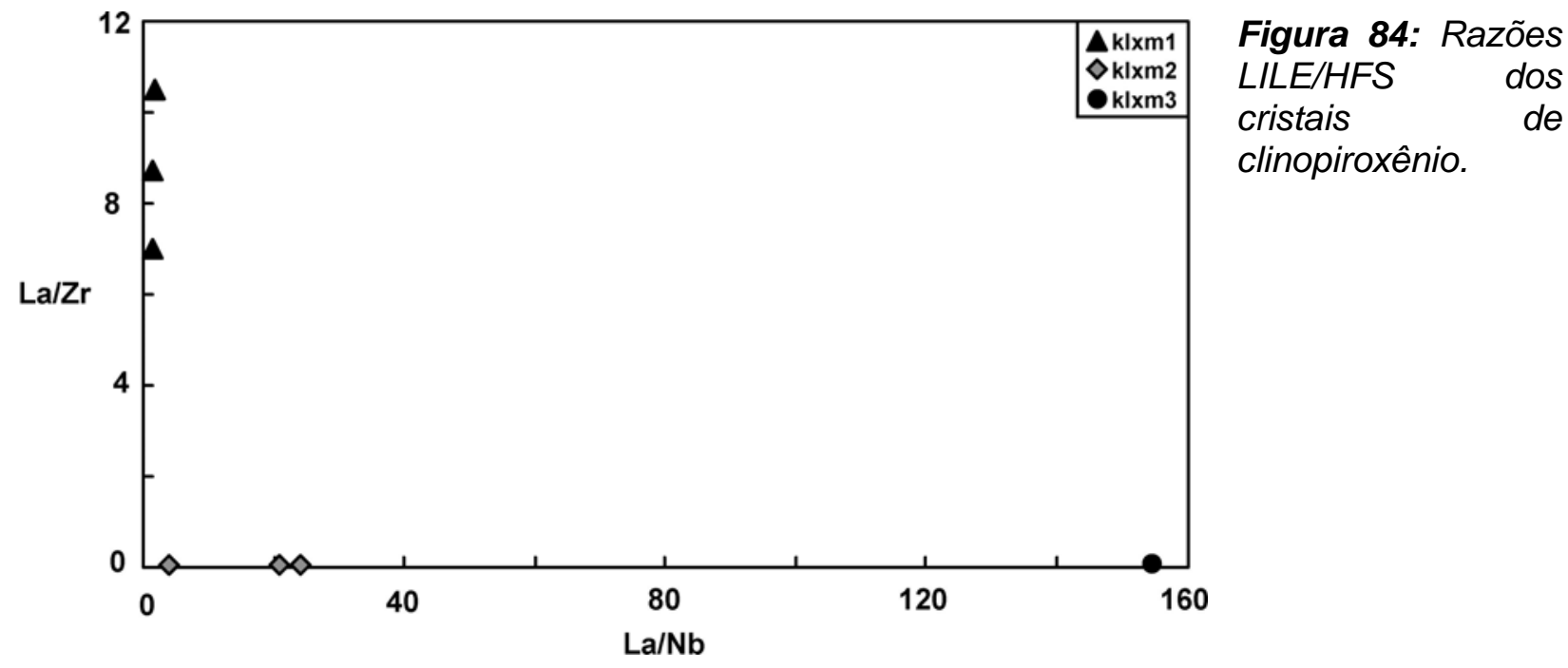

Os padrões de elementos terras-raras normalizados pelo condrito C1 de Mcdonough \& Sun (1995) são apresentados na Figura 85. Os cristais dos xenólitos Klxm2 (Mg\#= 89,9 a 90,2) e KIxm3 (Mg\#= 81,9 a 92,2) apresentam padrões com enriquecimento em ETRL $\left((\mathrm{La} / \mathrm{Yb})_{\mathrm{N}}=4 \mathrm{a}\right.$ 15) com forma convexa entre os ETRL com pico no $\mathrm{Nd}\left((\mathrm{La} / \mathrm{Nd})_{\mathrm{N}}<1\right)$. Análises de clinopiroxênio da suíte MARID e de peridotitos venulados metassomatizados de Kramers et al. (1983) foram utilizadas para comparação e mostram padrão ETR bastante similares aos padrões de Klxm2. Já os cristais de Klxm1 (Mg\# = 94,3 a 94,9) mostram padrões anômalos, no geral com leve enriquecimento de ETRL em relação aos ETRP $\left((\mathrm{La} / \mathrm{Yb})_{\mathrm{N}}=\right.$ até 1,6$)$, porém com valores de $\mathrm{Nd}$, Sm, Eu e $\mathrm{Gd}$ abaixo do condrito (e.g. $\sim 0,1$ x condrito para $\mathrm{Nd}$ ), e concentrações de Sm e Gd por vezes abaixo do limite de detecção. O enriquecimento relativo dos ETRP é evidenciado por razões $(\mathrm{Gd} / \mathrm{Lu})_{\mathrm{N}} \ll 1$.

Os cristais de clinopiroxênio de Klxm1 são muitas vezes encontrados em associação com ortopiroxênio e espinélio formando aglomerados e até mesmo uma banda com concentração desses três minerais, que são interpretados por diversos trabalhos (e.g. CominChiaramonti et al., 1986), incluindo de xenólitos do nordeste do Brasil (Fodor et al., 2002), como indicadores de presença pretérita de granada. Segundo Nicolas et al. (1987) aglomerados desse tipo poderiam ser derivados de granada e olivina, através de 
recristalização e exsolução no estado sólido, por descompressão. O clinopiroxênio gerado nessa exsolução herdaria o padrão de elementos incompatíveis da granada (Johnson et al., 1990), o que parece ser o caso desse padrão anômalo de ETR, onde o alto enriquecimento de ETRP em relação aos ETRM (elementos terras-raras médios), seria herança da composição da granada. O enriquecimento posterior em ETRL ( $L a, C e, \operatorname{Pr}$ ) deve ter sido causado por metassomatismo subseqüente.

Os padrões de elementos incompatíveis dos cristais de clinopiroxênio normalizados pelo manto primitivo de Sun \& Mcdonough (1989) são apresentados na Figura 86. Os cristais dos três xenólitos apresentam padrões bastante irregulares onde Klxm2 e Klxm3 mostram enriquecimento para boa parte desses elementos. Destacam-se anomalias negativas de $\mathrm{Zr}$ $\left((\mathrm{Sm} / \mathrm{Zr})_{\mathrm{N}}=1,3\right.$ a 2,6$)$ e $\mathrm{Ti}\left((\mathrm{Gd} / \mathrm{Ti})_{\mathrm{N}}=4,2\right.$ a 11,3$)$ nesses dois xenólitos. Os elementos menos incompatíveis que Ti, em Klxm2 e Klxm3, apresentam empobrecimento em direção ao Lu, com razões $(G d / L u)_{N}>1$. Já as análises do clinopiroxênio sem evidências de inclusões ou zoneamentos do xenólito Klxm1 apresentam concentrações mais baixas que o condrito para a maioria dos elementos (Rb-Ba, Pr-Er) e anomalias negativas de $\mathrm{Nb}\left((\mathrm{La} / \mathrm{Nb})_{\mathrm{N}}=1,3\right.$ a 1,7$)$ e $\mathrm{Zr}$ $\left((\mathrm{Sm} / \mathrm{Zr})_{\mathrm{N}}=\right.$ até 3$)$ e anomalia positiva de $\mathrm{Sr}\left((\mathrm{Nd} / \mathrm{Sr})_{\mathrm{N}}=0,05\right.$ a 0,07$)$. Os elementos menos incompatíveis que o $\mathrm{Ti}$ apresentam um enriquecimento em direção ao $\mathrm{Lu}$ com razões $\left((\mathrm{Gd} / \mathrm{Lu})_{N}<1\right)$. Dados os baixos teores de ETRM, não se definem anomalias negativas de Ti como observado nos outros dois xenólitos. Em contrapartida, a análise do clinopiroxênio desta mesma amostra (Klxm1) com inclusões ou zoneamentos, apresenta enriquecimento para a maioria dos elementos, com destaque para anomalias negativas de $\mathrm{Nb}\left((\mathrm{La} / \mathrm{Nb})_{\mathrm{N}}=3,4\right), \mathrm{Sr}$ $\left((\mathrm{Nd} / \mathrm{Sr})_{\mathrm{N}}=1,5\right)$ e $\mathrm{Ti}\left((\mathrm{Gd} / \mathrm{Ti})_{\mathrm{N}}=6,7\right)$.

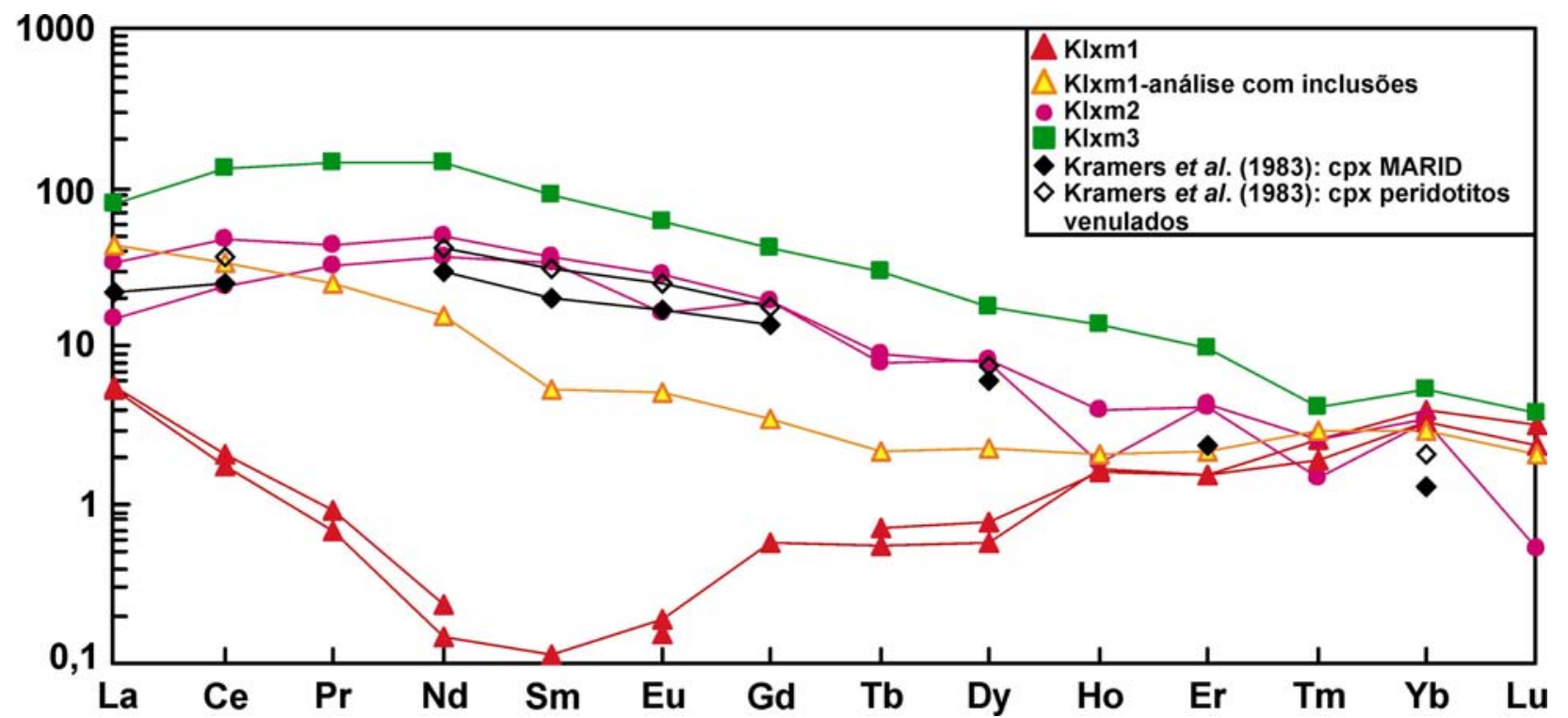

Figura 85: Padrões de elementos terras-raras de cristais de clinopiroxênio de xenólitos de Monte Carmelo normalizados ao padrão condrítico C1 de McDonough \& Sun (1995). Notar similaridade dos padrões de KIxm2 com os padrões de clinopiroxênios da suíte MARID e de peridotitos venulados de Kramers et al. (1983). 


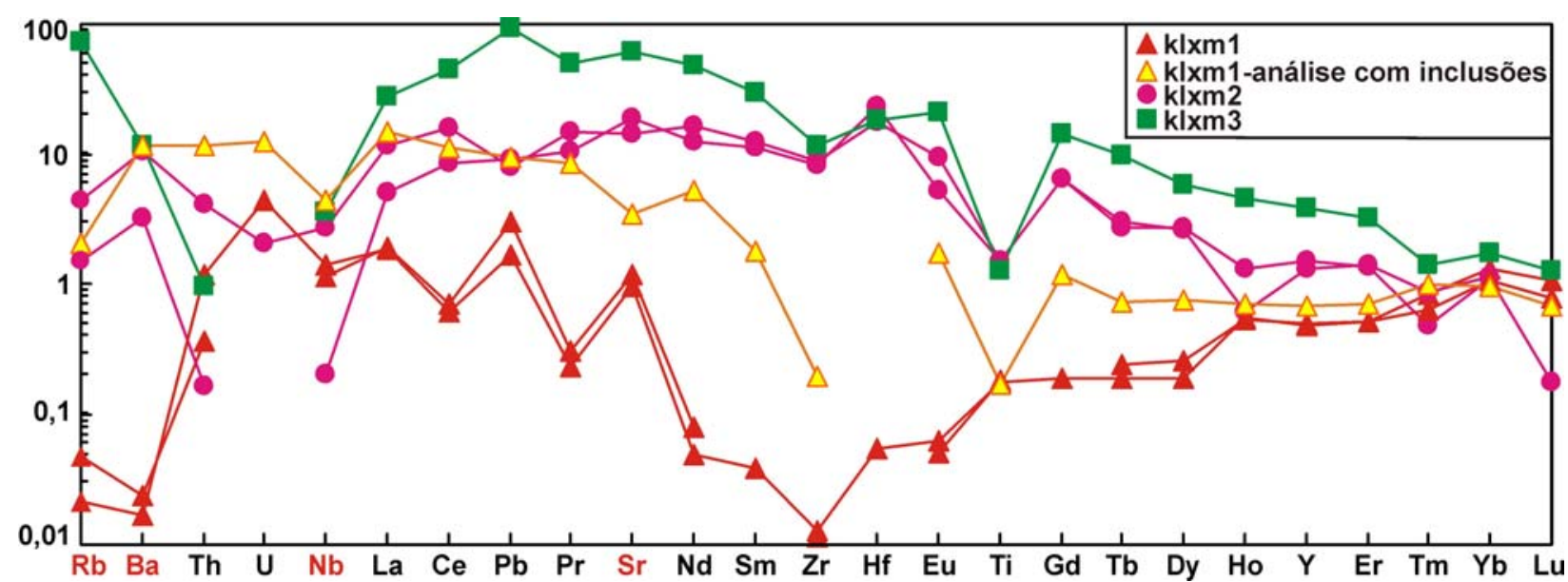

Figura 86: Padrões de elementos incompatíveis de cristais de clinopiroxênio de xenólitos de Monte Carmelo normalizados pelo manto primitivo de Sun \& Mcdonough (1989). Elementos relacionados às inclusões ou zoneamentos encontram-se em vermelho na escala..

\subsection{Petrogênese}

\subsubsection{Estimativas de temperatura}

Estimativas de temperaturas de equilíbrio também foram realizadas pelo programa PTEXL utilizando as composições químicas dos minerais principais dos xenólitos. Os resultados encontram-se na Tabela 7. As estimativas foram feitas com os mesmos geotermômetros usados para os xenólitos de Ubatuba. Apenas o método de Al em ortopiroxênio (Witt-Eickshen, 1991) foi utilizado para o xenólito Klxm2, já que as outras fases (clinopiroxênio e espinélio) encontram-se em desequilíbrio. $\mathrm{T}_{\text {Wells }}\left(822^{\circ} \mathrm{C}\right)$ do xenólito $\mathrm{KIxm} 1$ apresentou maior valor em relação à $\mathrm{T}_{\mathrm{BKN}}\left(763^{\circ} \mathrm{C}\right)$. Pelo mesmo método, a calibração de Bertrand \& Merrier $(1985)\left(761^{\circ} \mathrm{C}\right)$ forneceu valores praticamente iguais a $\mathrm{T}_{\mathrm{BKN}}$. Temperaturas obtidas pela troca de Fe-Mg entre olivina e espinélio (Ballhaus, 1991 e O’Neill \& Wall, 1987) são mais baixas $\left(638^{\circ} \mathrm{C}\right.$ e $\left.622^{\circ} \mathrm{C}\right)$. Assim como para Ubatuba, a estimativa por Al em ortopiroxênio (Witt-Eickshen, 1991) forneceu maior valor $\left(921^{\circ} \mathrm{C}\right)$. No caso do xenólito KIxm2 essa mesma estimativa apresentou valor bem mais baixo $\left(721^{\circ} \mathrm{C}\right)$.

A pressão máxima para a fácies espinélio, de acordo com a Figura 3, seria de cerca de 15 kbar para temperaturas da ordem de $800^{\circ} \mathrm{C}$, como as estimadas para os xenólitos estudados.

As temperaturas $T_{B K N}$ e $T_{\text {Wells }}$ obtidas para esses xenólitos se encontram dentro do intervalo atribuído por Meyer \& Svisero (1991) aos xenólitos dos kimberlitos Limeira 1 e Indaiá $1\left(750\right.$ a $\left.850^{\circ} \mathrm{C}\right)$. Temperatura de $785^{\circ} \mathrm{C}$ foi calculada para xenólitos de espinélio-flogopita Iherzolito do Kimberlito Três Ranchos 4 (Costa et al., 2008). Esse dado é semelhante à $\mathrm{T}_{\mathrm{BKN}}$ dos xenólitos do Kimberlito Limeira 1. 
Tabela 7: Temperaturas estimadas para xenólitos do Kimberlito Limeira 1. Temperatura em ${ }^{\circ} \mathrm{C}$ calculada por meio da média das composições dos núcleos dos cristais.

\begin{tabular}{llcc}
\hline Metodologia & Calibração & $\begin{array}{c}\text { Klxm1 } \\
\text { (Grupo 1) }\end{array}$ & $\begin{array}{c}\text { Klxm2 } \\
\text { (Grupo 2) }\end{array}$ \\
\hline Opx-Cpx solvus & BKN (Brey \& Koehler, & $\mathbf{7 6 3}$ & \\
& 1990) & 822 & \\
& Wells (1977) & $\mathbf{8 2 2}$ & \\
& Bertrand \& Merrier (1985) & 761 & \\
Ca em Opx & Brey \& Koehler (1990) & 854 & \\
Troca de Fe-Mg entre Ol e Sp & Ballhaus (1991) & 638 & \\
& O'Neill \& Wall (1987) & 622 & \\
Al em Opx & Witt-Eickshen (1991) & $\mathbf{9 2 1}$ & $\mathbf{7 6 0}$ \\
\hline
\end{tabular}

\subsubsection{Elementos traços em rocha total vs. elementos traços em clinopiroxênio}

Como o clinopiroxênio é o principal hospedeiro de elementos incompatíveis, o seu padrão de elementos terras-raras tende a imitar o padrão de rocha total (Bianchinni et al., 2007). No entanto, os padrões obtidos para os clinopiroxênios de Klxm1 (Figuras 85 e 86) nada têm a ver com o padrão de rocha total deste xenólito (Figuras 64 e 65). Na verdade, o padrão de rocha total se assemelha ao da análise de clinopiroxênio com inclusões ou zoneamentos envolvendo terras-raras (Figura 85 e 86), indicando que o padrão de rocha total é na verdade o resultado da soma das concentrações de cristais de clinopiroxênio incluindo possíveis zoneamentos, inclusões e material intergranular.

O padrão de rocha total de elementos terras-raras de Klxm2 se assemelha aos dos cristais de clinopiroxênio deste xenólito pelo enriquecimento em ETRL, porém não apresenta o padrão convexo observado entre esses elementos. Observa-se, no entanto, que o clinopiroxênio não é o principal hospedeiro de ETRL nesse xenólito, no qual os cristais de titanatos (mathiasita), com até 1\% de La e Ce, devem influenciar de modo decisivo a forma do padrão de rocha total.

\subsubsection{Modelos de fusão em equilíbrio e fusão fracionada}

Análises dos cristais de clinopiroxênio dos xenólitos Klxm1, Klxm2 e Klxm3 foram submetidas aos modelamentos de fusão em equilíbrio e fusão fracionada por meio das equações descritas em Norman et al. (1998), de modo análogo ao que foi feito para os xenólitos de Ubatuba. No entanto, como destacado anteriormente, a gênese dos cristais de clinopiroxênio dos xenólitos Klxm2 e Klxm3 está muito provavelmente relacionada a metassomatismo modal, identificado pela relação desses cristais com texturas secundárias (e.g. bolsões em Klxm2) e química semelhante a cristais da suíte MARID e de peridotitos venulados metassomatizados (e.g. baixíssimos teores de $\mathrm{Al}_{2} \mathrm{O}_{3}$ e enriquecimento em LILE e 
HFS). Deste modo sua composição química não deve ser resultado de eventos de fusão parcial, e não pode ser usada em modelamentos por fusão em equilíbrio e fracionada.

As curvas geradas pelos modelamentos encontram-se na Figura 87. Observa-se que as análises do clinopiroxênio de Klxm2 se encaixam nas duas curvas, porém seus resultados não possuem valor interpretativo, pelo exposto acima. Já as análises de Klxm3 são as mais dispersas e distantes das duas curvas.

Os pontos de análises de Klxm1 estão relativamente distantes das curvas, sendo que o mais próximo, encontra-se além do limite de $50 \%$ de fusão em equilíbrio (Figura 87a), valor considerado irreal. O mesmo ponto seria compatível com proporções entre 15 a $20 \%$ de fusão fracionada (Figura 87b), mas esses valores também são considerados altos uma vez que não parecem compatíveis com a proporção modal observada de clinopiroxênio ( 6\%) (e.g. Norman et al., 1998). Os padrões de elementos incompatíveis deste xenólito também são bastante distintos aos previstos pelos modelamentos (Figura 88). Esses cristais, portanto, também não apresentam composição química resultante de fusão parcial em fácies espinélio.

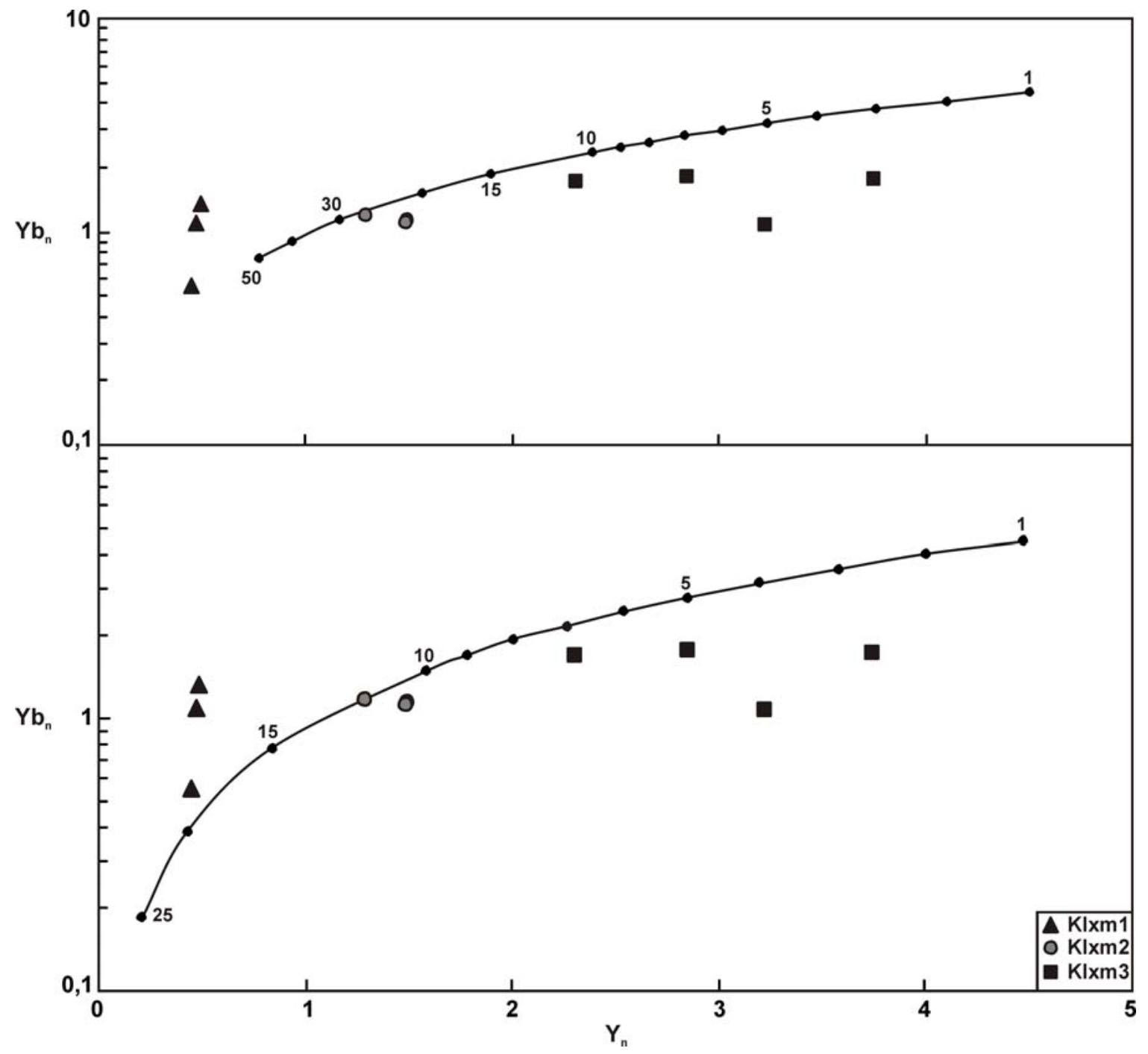

Figura 87: Correlação $Y_{n} \times Y b_{n}$ de cristais de clinopiroxênio plotadas em curvas geradas por modelamentos de fusão em equilíbrio (a) e fracionada (b). Calibração de Norman et al. (1998). Dados normalizados ao manto primitivo (3 x condrito de Anders \& Grevesse, 1989). 


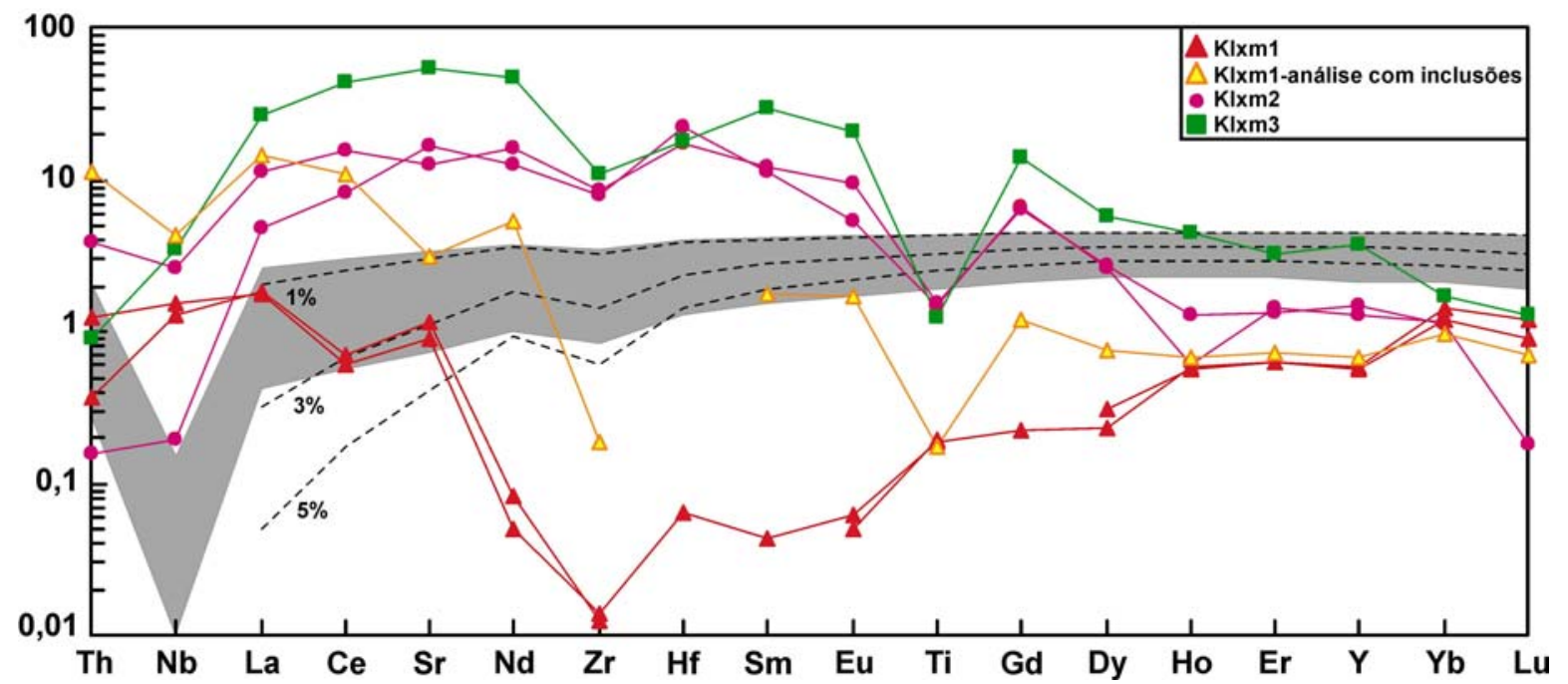

Figura 88: Padrões de elementos incompatíveis normalizados ao manto primitivo ( $3 x$ condrito C1 de Anders \& Grevesse, 1989) comparados com os padrões previstos por 1 a 12\% de fusão em equilíbrio (região cinza) e 1, 3 e 5\% de fusão fracionada (linhas tracejadas).

\subsection{Discussão}

A termometria mostrou que alguns xenólitos do Kimberlito Limeira 1 representam fragmentos mantélicos com temperatura que varia de 760 a $820^{\circ} \mathrm{C}$.

A Tabela 8 mostra um quadro comparativo entre os grupos de xenólitos estudados do Kimberlito Limeira 1. Nessa localidade, os clássicos índices de empobrecimento como o Mg\# das fases minerais, a proporção modal e teores de $\mathrm{Al}_{2} \mathrm{O}_{3}$ e $\mathrm{Na}_{2} \mathrm{O}$ de clinopiroxênio, além do $\mathrm{Cr \#}$ de espinélio, não são aplicáveis para interpretações quanto à variação do grau de extração de componentes basálticos entre os xenólitos. Isto se deve ao fato de que os cristais dos xenólitos dos grupos 2 e 3 mostram uma química mineral bastante afetada pela presença de fases minerais metassomáticas (e.g. clinopiroxênio, ilmenita, flogopita).

O clinopiroxênio, quando em texturas secundárias (bolsões) ou em outras feições de desequilíbrio com os demais cristais, sempre mostra teores baixíssimos de $\mathrm{Al}_{2} \mathrm{O}_{3}$, maiores teores de $\mathrm{TiO}_{2}$ e um enriquecimento pronunciado de LILE e HFS com padrão ETR enriquecido em ETRL. Todas essas características são semelhantes às encontradas em cristais de clinopiroxênio da suíte MARID e de peridotitos venulados metassomatizados estudados por Kramers et al. (1983). A forma convexa do padrão de ETRL também é semelhante à observada em cristais de clinopiroxênio formados por reação com fundidos alcalinos (Bianchinni et al., 2007) A flogopita também mostra carência de Al e por vezes altos teores de $\mathrm{TiO}_{2}$, como nas bordas de cristais do grupo 3 (Klxm3).

A assinatura do metassomatismo nos minerais dos grupos 2 e 3 , portanto, está sempre relacionada ao enriquecimento de LILE e HFS em clinopiroxênio e à carência de Al em todas as 
fases minerais. Enriquecimento de $\mathrm{TiO}_{2}$ é observado seja pelo maior teor deste óxido em ortopiroxênio, clinopiroxênio e flogopita, seja pela presença de minerais de Ti como ilmenita, rutilo e priderita, em Klxm3, e ilmenita e mathiasita em Klxm2, destacando-se que priderita e mathiasita são minerais estritamente relacionados com metassomatismo no manto superior (Haggerty et al., 1983 e Foley et al. 1994).

A composição química do espinélio do grupo 2 (Klxm2) também parece ter sido bastante afetada pelo metassomatismo. Segundo Comin-Chiaramonti et al. (1986), o crescimento de fases hidratadas (anfibólio e flogopita) pode afetar a composição química do espinélio, de modo que para valores semelhantes de $m g_{\text {opx }}\left(\mathrm{Mg} / \mathrm{Fe}^{2+}+\mathrm{Fe}^{3+}\right)$ os espinélios são mais ricos em $\mathrm{Cr}$ nas paragêneses hidratadas em relação às anidras.

O xenólito estudado do grupo 1 (Klxm1), sem fases metassomáticas (flogopita, ilmenita) e menos deformado, mostra evidências distintas dos outros dois grupos. Os Mg\# das fases minerais são em geral maiores e os cristais de orto e clinopiroxênio apresentam teores maiores de $\mathrm{Al}_{2} \mathrm{O}_{3}$. Os $\mathrm{Cr} \#$ de espinélio são menores em relação a $\mathrm{KIxm} 2$ e mostram valores relacionados a harzburgito com clinopiroxênio (Fodor et al., 2002) e não a Iherzolito como modalmente indicado. Ocorre uma refertilização relacionada estritamente aos LILE com altas razões LILE/HFS típicas de metassomatismo por fluidos de zona de subducção. O padrão ETR do clinopiroxênio é anômalo, com enriquecimento de alguns ETRL, porém com grande empobrecimento dos ETRM, entre Nd e Gd. Evidências petrográficas como a presença de aglomerados de orto, clinopiroxênio e espinélio sugerem a presença pretérita de granada (mineral que tipicamente tem elevada proporção ETRP/ETRM) possivelmente responsável por esse padrão anômalo.

Os modelamentos de fusão em equilíbrio e fracionada não se aplicaram aos xenólitos, visto que vários fatores químicos e petrográficos indicam que a composição química dos cristais de clinopiroxênio não são resultado de empobrecimento por extração de fundido em fácies espinélio. 
Tabela 8: Quadro comparativo com as características gerais dos xenólitos do Kimberlito Limeira 1.

\begin{tabular}{|c|c|c|c|}
\hline & Grupo 1 & Grupo 2 & Grupo 3 \\
\hline Xenólitos & KIxm1 e KIxm5 & KIxm2, KIxm4 e KIxm6 & KIxm3 \\
\hline Classificação & Sp peridotitos & Sp-phl peridotitos & Phl-ilm clinopiroxenitos \\
\hline Textura & protogranular & protogr.e transicional & protogranular \\
\hline Sp & Abundante & Abundante & traço \\
\hline Mg\# ol & 92 & 88 & 81 a 90 \\
\hline $\mathrm{Cr}$ ol & até $7 \mathrm{ppm}$ & até $0,06 \%$ de $\mathrm{Cr}_{2} \mathrm{O}_{3}$ & até $0,1 \%$ de $\mathrm{Cr}_{2} \mathrm{O}_{3}$ \\
\hline $\mathrm{NiO}$ ol & até $0,4 \%$ & até $0,4 \%$ & até $0,1 \%$ \\
\hline Mg\# opx & 91,7 a 91,9 & até 89,9 & $(-)$ \\
\hline $\mathrm{Al}_{2} \mathrm{O}_{3} \mathrm{opx}$ & até 3\% & até $0,3 \%$ & $(-)$ \\
\hline $\mathrm{TiO}_{2}$ opx & até $0,04 \%$ & até $0,3 \%$ & $(-)$ \\
\hline$M g \# \mathbf{c p x}$ & 94,3 a 94,9 & 89,9 a 90,2 & 81,9 a 92,2 \\
\hline $\mathrm{Al}_{2} \mathrm{O}_{3} \mathrm{cpx}$ & até $3,7 \%$ & até $0,9 \%$ & 0,04 a $0,6 \%$ \\
\hline $\mathrm{TiO}_{2} \mathrm{cpx}$ & até $0,09 \%$ & até $0,5 \%$ & até $0,8 \%$ \\
\hline $\mathrm{Na}_{2} \mathrm{O} \mathrm{cpx}$ & até $1,2 \%$ & até $1,3 \%$ & 0,5 a $1,7 \%$ \\
\hline Cr\# sp & $\sim 0,3$ & 0,9 & $(-)$ \\
\hline $\mathrm{Al}_{2} \mathrm{O}_{3} \mathrm{sp}$ & até $41 \%$ & até 3,5\% & $(-)$ \\
\hline Flogopita & $(-)$ & Abundante & abundante \\
\hline$(\mathrm{Si}+\mathrm{Al}) \mathrm{Phl}$ & $(-)$ & $\mathrm{Si}+\mathrm{Al}<8$ & $\mathrm{Si}+\mathrm{Al}<8$ \\
\hline IImenita & $(-)$ & Mg-ilmenita & Mg-ilmenita \\
\hline Mathiasita & $(-)$ & Mathiasita-cromita & $(-)$ \\
\hline \multirow[t]{2}{*}{ Priderita } & $(-)$ & $(-)$ & Priderita-rutilo-ilmenita \\
\hline & $(\mathrm{La} / \mathrm{Yb})_{\mathrm{N}}>1 ; \mathrm{Nd}-$ & $(\mathrm{La} / \mathrm{Yb})_{\mathrm{N}}=4$ a 10 & $(\mathrm{La} / \mathrm{Yb})_{\mathrm{N}}=15 ; \mathrm{ETRL}$ \\
\hline ETR cpx & $\begin{array}{l}\mathrm{Gd}<\text { condrito; } \\
(\mathrm{Gd} / \mathrm{Lu})_{N}<1\end{array}$ & ETRL convexo & convexo \\
\hline$(\mathrm{La} / \mathrm{Nb})_{\mathrm{N}} \mathrm{cpx}$ & até 1,7 & 4,3 a 24,9 & até 7,6 \\
\hline$(L a / N d)_{N} c p x$ & 24,8 a 38 & 0,4 a 0,7 & até 0,6 \\
\hline$(G d / T i)_{N} c p x$ & até 1 & até 4,4 & até 11,2 \\
\hline$(\mathrm{Nd} / \mathrm{Sr})_{\mathrm{N}} \mathrm{cpx}$ & até 0,07 & Até 1 & até 0,8 \\
\hline$(\mathrm{Sm} / \mathrm{Zr})_{\mathrm{N}} \mathrm{cpx}$ & até 3 & até 1,4 & até 2,6 \\
\hline Fusão em equilíbrio & $(-)$ & $(-)$ & $(-)$ \\
\hline Fusão fracionada & 15 a $20 \%$ & $(-)$ & $(-)$ \\
\hline Enriquecimento & LILE & LILE e HFS & LILE e HFS \\
\hline
\end{tabular}




\section{DISCUSSÃO INTEGRADA E CONSIDERAÇÕES FINAIS}

O estudo realizado nos xenólitos mantélicos mostrou uma evidente distinção entre as localidades estudadas (Ubatuba e Monte Carmelo), relacionadas a diferentes contextos geológicos (Faixa Ribeira vs. Faixa Brasília) e também distintas rochas encaixantes (lamprófiro vs. kimberlito). Temperaturas de 750 a $950^{\circ} \mathrm{C}$ foram estimadas para os xenólitos de Ubatuba, enquanto temperaturas de 760 a $820^{\circ} \mathrm{C}$ foram calculadas para os de Monte Carmelo. Ambas as regiões apresentam temperaturas menores em relação àquelas registradas em xenólitos de fácies espinélio do nordeste do Brasil $\left(800\right.$ a $\left.1250^{\circ} \mathrm{C}\right)$, relacionados à pluma de Fernando de Noronha (Fodor et al, 2002).

A petrografia mostrou maior variedade mineralógica e textural nos espécimes do Kimberlito Limeira 1 (Monte Carmelo) onde, além dos minerais essenciais de espinélio peridotitos, também ocorrem outras fases subordinadas, por vezes exóticas e relacionadas com metassomatismo modal mantélico. Na Praia Vermelha (Ubatuba) a textura é quase sempre protogranular e predominam os minerais essencias de espinélio peridotitos e apenas alguns cristais de sulfetos.

Os xenólitos maiores de Ubatuba representam, na maioria das vezes, espinélio Iherzolitos com índices de empobrecimento por extração de fundidos compatíveis com os de Iherzolitos férteis (Fodor et al. 2001, Arai et al. 1994) e que mostram padrões de elementos traços por vezes com enriquecimento exclusivo de LILE (Ba, Sr, ETRL), sugerindo interação com fluidos de zonas de subducção. Em geral, é possível estabelecer uma separação entre alguns dos espécimes pelos diferentes graus de empobrecimento em componentes basálticos.

Relação semelhante de empobrecimento não pôde ser estabelecida nos espécimes do Kimberlito Limeira 1, já que as fases minerais de parte dos xenólitos encontram-se bastante afetadas pelo metassomatismo modal, representado pela presença constante de bolsões ricos em flogopita nas amostras mais deformadas. Para Downes (1990) os minerais metassomáticos tendem a ocorrer realmente em regiões mais deformadas, por onde o fluxo de fluidos/fundido é facilitado. Segundo Carlson et al. (2007) o metassomatismo atuante em xenólitos de Coromandel (Província do Alto do Paranaíba) pode ter idade máxima referente ao Ciclo Brasiliano (tardi-Neoproterozóico).

As amostras do Kimberlito Limeira 1 que não apresentam evidências de metassomatismo modal mostram textura indicativa de evolução do manto para pressões mais baixas, e um empobrecimento em componentes basálticos maior em relação aos encontrados em Ubatuba, indicado pelos $\mathrm{Mg} \#$ das fases silicáticas, $\mathrm{C} \#$ de cristais de espinélio e teores de $\mathrm{Al}_{2} \mathrm{O}_{3}$ e $\mathrm{Na}_{2} \mathrm{O}$ de piroxênios.

As texturas de desequilíbrio das duas localidades mostram minerais com semelhanças químicas que consistem sempre em teores muito baixos de $\mathrm{Al}_{2} \mathrm{O}_{3}$ e notável enriquecimento em 
LILE e HFS. Existe a possibilidade do fluido/fundido metassomatizante ser pobre em Al, aliado com o fato de a interação ter ocorrido em peridotito já bastante empobrecido neste elemento. De acordo com Toramaru \& Fujii (1986) as regiões mantélicas mais empobrecidas (ricas em olivina) são as mais pervasivamente infiltradas por fluidos/fundidos devido a maior permeabilidade dessas rochas. No caso específico de Monte Carmelo, essas fases metassomáticas mostram semelhanças químicas com as fases minerais da suíte MARID e de peridotitos venulados metassomatizados estudadas em xenólitos de kimberlitos da África do Sul (e.g. Kramers et al., 1983), o que vai de encontro com Meyer \& Svisero (1991) de que os xenólitos do kimberlito Limeira 1 apresentam metassomatismo modal semelhante aos xenólitos de kimberlitos daquela localidade.

As duas regiões (Ubatuba e Monte Carmelo) mostram diferentes evidências de processos de empobrecimento e metassomatismo, o que pode refletir uma variabilidade lateral do manto superior de fácies espinélio do sudeste brasileiro, possivelmente relacionada com os processos geológicos (tectônicos e magmáticos) distintos vivenciados pelas duas regiões. 


\section{REFERÊNCIAS BIBLIOGRÁFICAS}

Almeida, F.F.M. 1958. Geologia e petrologia do arquipélago de Fernando de Noronha. Divisão de Geologia e Mineralogia. Departamento Nacional de Produção Mineral. Ministério da Agricultura. Monografia. Rio de Janeiro.

Anders, E. \& Grevesse, N. 1989. Abundances of the elements: meteoritic and solar. Geochimica et Cosmochimica Acta, 53: 197-214.

Aoki, K. 1974. Phlogopites and potassic richterites from mica nodules in South African kimberlites. Contributions to Mineralogy and Petrology, 48: 1-7.

Arai, S. 1994. Characterization of spinel peridotites by olivine-spinel compositional relationships: review and interpretations. Chemical Geology, 113: 191-204.

Araújo, A.L.N.; Carlson, R.W.; Gaspar, J.C. \& Bizzi, L.A. 2001. Petrology of kamafugites and kimberlites from the Alto Paranaíba Alkaline Province, Minas Gerais, Brazil. Contributions to Mineralogy and Petrology, 142(2): 63-177.

Ballhaus, C.; Berry, R.F. \& Green, D.H. 1991. High pressure experimental calibration of the olivine-orthopyroxene spinel oxygen geobarometer: implications for the oxidation state of the upper mantle. Contributions to Mineralogy and Petrology, 107:27-40.

Barbarin, B. 1999. A review of the relationships between granitoid types, their origins and their geodynamic environments. Lithos. 46: 605-626.

Barnes, S.J. \& Roeder, P.L. 2001. The range of spinel compositions in terrestrial mafic and ultramafic rocks. Journal of Petrology, 42(12): 2279-2302.

Bastin, G.F.; van Loo, F.J.J. \& Heijligers, H.J.M. 1984. Evaluation and use of gaussian ( $\Phi(p z))$ curves in quantitative electron probe microanalysis: a new optimization. $X$-ray Spectometry, 13: 91-97.

Batanova, V.G. \& Sobolev, A.V. 2000. Compositional heterogeniety in subduction related mantle peridotite, Troodos massif, Cypress. Geology, 28: 55-58.

Beard, A.D.; Downes, H.; Mason, P.R.D. \& Vetrin, V.R. 2007. Depletion and enrichment processes in the lithospheric mantle beneath the Kola Peninsula (Russia): Evidence from spinel Iherzolite and wehrlite xenoliths. Lithos, 94: 1-24.

Bedini, R.M. \& Bodinier, J.L. 1999. Distribution of incompatible trace elements between the constituents of spinel peridotite xenoliths: ICP-MS data from East African Rift, Geochimica et Cosmochimica Acta, 63(22): 3883-3900.

Bellieni, G.; Montes-Lauar, C.R.; De Min, A.; Piccirillo, E.M.; Cavazzini, G.; Melfi A.J. \& Pacca, I.G. 1990. Early and Late Cretaceous magmatism from São Sebastião island (SEBrazil): geochemistry and petrology, Geochimica Brasiliensis, 4: 59-83.

Bertrand, P. \& Merrier, J.C.C. 1985. The mutual solubility of coexisting ortho- and clinopyroxene: toward an absolute geothermometer for the natural system? Earth and Planetary Science Letters, 76: 109-122.

Bianchini, G.; Beccaluva, L.; Bonadiman, C.; Nowell, G.; Pearson, G.; Siena, F. \& Wilson, M. 2007. Evidence of diverse depletion and metasomatic events in harzburgite-lherzolite 
mantle xenoliths from the Iberian plate (Olot, NE Spain): Implications for lithosphere accretionary processes. Lithos, 94: 25-45.

Bizzi, L.A.; Smith, C.B.; De Wit, M.J.; Armstrong, R.A. \& Meyer, H.O.A. 1994. Mesozoic kimberlites and related rocks in the southwestern São Francisco Craton: a case for local mantle reservoirs and their interaction. Proceedings of the $5^{\text {th }}$ International Kimberlite Conference, Araxá (Minas Gerais, Brazil). CPRM Special Publication 1/A, Brasília, 156171.

Blundy, J. \& Wood, B. 2003. Partitioning of trace elements between crystals and melts. Earth and Planetary Science Letters, 210: 383-397.

Brey, G.P. \& Koehler, T. 1990. Geothermobarometry in four-phase lherzolites II: New thermobarometers, and practical assessment of existing thermobarometers. Journal of Petrology, 31: 1353-1378.

Brod, J.A.; Gaspar, J.C.; Araújo, D.P.; Gibson, S.A.; Thompson, R.N. \& Junqueira-Brod, T.C. 2001. Phlogopite and tetra-ferriphlogopite from Brazilian carbonatite complexes: petrogenetic constraints and implications for mineral-chemistry systematics. Journal of Asian Earth Sciences, 19: 265-296.

Brotzu, P.; Melluso, L.; D’Amelio, F \& Lustrino, M. 2005. Potassic dykes and intrusions of the Serra do Mar Igneous Province (SE Brazil). In: Comin-Chiaramonti, P. \& C.B. Gomes (eds.). Mesozoic to Cenozoic Alkaline Magmatism in the Brazillian Platform. EduspFapesp, p. 443-472.

Carlson, R.W.; Esperança, S. \& Svisero, D.P. 1996. Chemical and isotopic study of Cretaceous potassic rocks from southern Brazil. Contributions to Mineralogy and Petrology, 125:393405.

Carlson, R.W.; Araújo, A.L.N.; Junqueira-Brod, T.C.; Gaspar, J.C.; Brod, J.A.; Petrinovic, I.A.; Hollanda, M.H.B.M.; Pimentel, M.M. \& Sichel, S. 2007. Chemical and isotopic relationships between peridotites xenoliths and mafic-ultrapotassic rocks from Southern Brazil. Chemical Geology, 242: 415-434.

Carmichael, I.S.E. 1967. The iron-titanium oxides of salic volcanic rocks and their associated ferromagnesian silicates. Contributions to Mineralogy and Petrology, 14: 36-64.

Carvalho, J.B. 1997. Petrologia de xenólitos mantélicos da Província do Alto Paranaíba, Minas Gerais. Tese de doutorado. Instituto de Geociências. Universidade de Brasília.

Comin-Chiaramonti, P.; Demarchi, G.; Girardi, V.A.V.; Princivalle, F. \& Sinigoi, S. 1986. Evidence of mantle metasomatism and heterogeneity from peridotite inclusions of northeastern Brazil and Paraguay. Earth and Planetary Science Letters, 77:203-217.

Comin-Chiaramonti, P.; Cundari, A.; Piccirillo, E.M.; Gomes, C.B.; Castorina, F.; Censi , P.; Demin A.; Marzoli, A.; Speziale, S. \& Velázquez, V.F. 1997. Potassic and sodic igneous rocks from Eastern Paraguay: their origin from the lithospheric mantle and genetic relationships with the associated Paraná flood tholeiites. Journal of Petrology, 38: 495528.

Costa, V.S. 1996. Estudos mineralógicos e químicos do kimberlito Batovi 6 (MT) em comparação com as intrusões Três Ranchos 4 (GO) e Limeira 1 (MG). Dissertação de Mestrado. Instituto de Geociências. Universidade Estadual de Campinas. 
Costa, V.S.; Figueiredo, B.R. \& Weska, R.K. 1997. Estudos mineralógicos e químicos do kimberlito Batovi 6 (MT) em comparação com as intrusões Três Ranchos 4 (GO) e Limeira 1 (MG). Geochimica Brasiliensis, 11(1): 53-71.

Costa, V.S. \& Gaspar, J.C. 2001. Intercrescimento gráfico de ilmenita-clinopiroxênio em nódulos de kimberlito de Juína, MT: petrografia e química mineral. Revista Brasileira de Geociências, 31(4): 569-574.

Costa, G.V.; Gaspar, J.C.; Moraes, R.; Coelho-Silva, A.T.M. \& Carneiro, S. 2008. Mantle xenoliths from Canastra-01 kimberlite, Brazil. Proceedings of the $9^{\text {th }}$ International Kimberlite Conference. Extended Abstracts.

Danchin, R.V. \& D'Orey, F. 1972. Chromian spinel exsolution in ilmenite from the Premier Mine, Transvaal, South Africa. Contributions to Mineralogy and Petrology, 35: 43-49.

Dawson, J.B. \& Smith, J.V. 1977. The MARID (Mica Amphibole Rutile Ilmenite Diopside) suite of kimberlite xenoliths. Geochimica et Cosmochimica Acta, 41: 309-323.

Dawson, J.B. (ed.) 1980. Kimberlites and their xenoliths. Springer-Verlag, Berlin, 252p.

Dawson, J.B. 1982. Contrasting types of mantle metasomatism. Terra Cognita, 2: 232.

Dawson, J.B. 1987. The MARID suite of xenoliths in kimberlite: relationship to veined and metasomatised peridotite xenoliths. In: Nixon, P.H. (ed.). Mantle xenoliths. John Wiley \& Sons, 465-473.

Donatti Filho, J.P.; Oliveira, E.P.; Pisani, J.R.T. \& Ochika, F.P. 2008. The geology, mineralogy and geochemistry of the Neoproterozoic Brauna kimberlite Province, São Francisco Craton, Bahia, Brazil. Proceedings of the $9^{\text {th }}$ International kimberlite conference. Extended Abstracts.

Downes, H. 1990. Shear zones in the upper mantle - Relation between geochemical enrichment and deformation in mantle peridotites. Geology, 18: 374-377.

Eggins, S.M.; Rudnick, R.L. \& McDonough, W.F. 1998. The composition of peridotites and their minerals: a laser-ablation ICP-MS study. Earth and Planetary Science Letters, 154: 5371.

Enrich, G.E.R.; Azzone, R.G.; Ruberti, E.; Gomes, C.B.; Comin-Chiaramonti, P. 2005. Itatiaia, Passa Quatro and São Sebastião island, the major alkaline syenitic complexes from the Serra do Mar region. In: P. Comin-Chiaramonti \& C.B. Gomes (eds.). Mesozoic to Cenozoic Alkaline Magmatism in the Brazilian Platform, 419-442.

Fan, Q. \& Hooper, P.R. 1989. The mineral chemistry of ultramafic xenoliths of eastern China: implications for upper mantle composition and the paleogeotherms. Journal of Petrology, 30: 1117-1158.

Fodor, R.V.; Sial, A.N.; Gandhok, G. 2002. Petrology of spinel peridotite xenoliths from northeastern Brazil: lithosphere with a high geothermal gradient imparted by Fernando de Noronha plume. Journal of South America Earth Sciences, 15: 199-214.

Foley, S.; Höfer, H.E. and Brey, G.P. 1994. High-pressure synthesis of priderite and members of the lindsleyite-mathiasite and hawthorneite-yimengite series. Contributions to Mineralogy and Petrology, 117: 164-174. 
Garda, G.M. 1995. Os diques básicos e ultrabásicos da região costeira entre as cidades de São Sebastião e Ubatuba, Estado de São Paulo. Tese de doutorado. Instituto de Geociências. Universidade de São Paulo.

Garda, G.M.; Schorscher, H.D.; Esperança, S. \& Carlson, R.W. 1995. The petrology and geochemistry of coastal dikes from São Paulo State, Brazil: implications for variable lithospheric contributions to alkaline magmas from the western margin of the South Atlantic. Anais da Academia Brasileira de Ciências, 67: 191-216.

Gaspar, J.C.; Conceição e Silva, A.J.G. e Araújo, D.P. 1994. Composition of priderite in phlogopitites from the Catalão I carbonatite complex, Brazil. Mineralogical Magazine, 58 (3): 409-415.

Gibson, S.A.; Thompson, R.N.; Leonardos, O.H.; Dickin, A.P. \& Mitchell, L.G. 1995. The late cretaceous impact of the Trindade mantle plume: evidence from large volume, mafic, potassic magmatism in southeastern Brazil. Journal of Petrology, 36(1): 189-229.

Grégoire, M.; Tinguely, C.; Bell, D.R. \& Le Roex, A.P. 2005. Spinel Iherzolite xenoliths from the Premier kimberlite (Kaapvaal craton, South Africa): Nature and evolution of the shallow upper mantle beneath the Bushveld complex. Lithos, 84: 185-205

Griffin, W.L.; Smith, D.; Ryan, C.G.; O’Reilly, S.Y. \& Win, T.T. 1996. Trace element zoning in mantle minerals: Metasomatism and thermal events in the upper mantle. Canadian Mineralogist, 34: 1179-1193.

Haggerty, S.E. 1975. The chemistry and genesis of opaque minerals in kimberlites. Physics and Chemistry of the Earth, 9: 295-307.

Haggerty, S.E.; Smyth, J.R.; Erlank, A.J.; Rickard, R.S. \& Dachin, R.V. 1983. Lindsleyite (Ba) and Mathiasite $(\mathrm{K})$ : two new chromium-titanates in the crichtonite series from the upper mantle. American Mineralogist, 68: 494-505.

Haggerty, S.E. 1995. Upper mantle mineralogy. Journal of Geodynamics, 20(4): 331-364.

Harte, B. 1977. Rock nomenclature with particular relation to deformation and recrystallisation textures in olivine-bearing xenoliths. Journal of Geology, 85: 279-288.

Harte, B. 1987. Metasomatic events recorded in mantle xenoliths: an overview. In: Nixon, P.H. (ed.). Mantle xenoliths. John Wiley \& Sons, 625-640.

Hawkesworth, C.J.; Mantovani, M. \& Peate, D. 1988. Lithosphere remobilization during Paraná CFB magmatism. In: Journal of Petrology, Special Lithosphere Issue, 205-223.

Heaman, L.; Teixeira, N.A.; Gobbo, L. \& Gaspar, J.C. 1998. U-Pb mantle zircon ages for kimberlites from the Juína and Paranatinga provinces, Brazil. Proceedings of the $7^{\text {th }}$ International Kimberlite Conference, Cape Town. Extended Abstracts, 322-324.

Hellebrand, Eric; Snow, J.E.; Dick, H.J.B. \& Hofmann, A.W. 2001. Coupled major and trace elements as indicators of the extent of melting in mid-ocean-ridge peridotites. Nature, 410: $677-681$.

Helmbold, R. 1968. Ultrabasic nodules in analcite basanite of Guaratiba, state of Guanabara, Brazil. Anais da Academia Brasileira de Ciências, 40: 141-147.

Hirshmann, M.M. 2000. Mantle solidus: experimental constraints and the effects of peridotite composition. Geochemistry Geophysics Geosystems, 1 (20001024). 
Ionov, D.A.; Ashchepkov, I.V.; Stosch, H.G.; Witt-Eickschen, G. \& Seck, H.A. 1993a. Garnet peridotite xenoliths from the Vitim volcanic field, Baikal Region: the nature of the garnetspinel peridotite transition zone in the continental mantle. Journal of Petrology, 34: 11411175.

Jackson, S.E.; Longerich, H.P.; Dunning, G.R. \& Fryer, B.J. 1992. The application of laserablation microprobe-inductively coupled plasma-mass-spectrometry (LAM-ICP-MS) to in situ trace-element determinations in minerals. Canadian Mineralogist, 30: 1049-1064.

Janasi, V.A.; Vlach, S.R.F. \& Ulbrich, H.H.G.J. 1993. Enriched-mantle contributions to the Itu granitoid belt, southeastern Brazil: evidence from K-rich diorites and syenites, Anais da Academia Brasileira de Ciências, 65(1): 107-118.

Janasi, V.A.; Andrade, S.; Ulbrich, H.H.G.J. 1995. A correção do drift instrumental em ICP-AES com espectômetro seqüencial e a análise de elementos maiores, menores e traços em rochas. Boletim IG-USP. Série Científica, 26: 45-58.

Janasi, V.A.; Alves, F.R.; Almeida, V.V. \& Ruberti, E. 2006. A note on the occurrence of spinel Iherzolite mantle xenoliths in a lamprophyre dike, Ubatuba (SP). In: Congresso Brasileiro de Geologia, 43, Aracaju-SP, Sociedade Brasileira de Geologia. Anais.

Johnson, K.T.M.; Dick, H.J.B. \& Shimizu, N. 1990. Melting in the oceanic upper mantle: na ion microprobe study of diopsides in abyssal peridotites. Journal of Geophysical Research, 95: 2661-2678.

Koga, K.T.; Shimizu, N. \& Grove, T.L. 1999. Disequilibrium trace element redistribution during garnet to spinel fácies transformation. In: Proceedings of the 7th International Kimberlite Conference, 444-451.

Kogarko, L.N.; Kurat, G. \& Ntaflos, T. 2001. Carbonate metasomatism of the oceanic mantle beneath Fernando de Noronha Island, Brazil. Contributions to Mineralogy and Petrology, 140: $577-587$.

Kramers, J.D.; Roddick, J.C.M. \& Dawson, J.B. 1983. Trace element and isotope studies on veined, metasomatic and "MARID" xenoliths from Bultfontein, South África. Earth and Planetary Science Letters, 65: 90-106.

Kubo, K. 2002. Dunite formation processes in highly depleted peridotite: case study of the Iwanaidake peridotite, Hokkaido, Japan. Journal of Petrology, 43(3): 423-448.

Leonardos, O.H.; Carvalho, J.B.; Tallarico, F.H.B.; Gibson, S.A.; Thompson, R.N.; Meyer, H.O.A. \& Dickin, A.P. 1993. O xenólito de granada Iherzolito de Três Ranchos 4: uma rocha matriz do diamante na província magmática cretácea do Alto Paranaíba, Goiás, In: R. Weska; O.H. Leonardos \& G.M. Gonzaga (eds.). Simpósio Brasileiro de Geologia do Diamante, I, Cuiabá. Anais. Publicação Especial-UFMT 2/93, 3-16.

Matson, D.W.; Muenow, D.W. \& Garcia, M.O. 1986. Volatile contents of phlogopite micas from South African kimberlite. Contributions to Mineralogy and Petrology, 93: 399-408.

McDonough, W.F.; Stosch, H.G. \& Ware, N.G. 1991. Distribution of titanium and the rare earth elements between peridotitic minerals. Contributions to Mineralogy and Petrology, 110: 321-328.

Mcdonough, W.F. \& Sun, S. 1995. The composition of the Earth. Chemical Geology, 120: 223253. 
Mercier, J.C.C. \& Nicolas, A. 1975. Textures and fabrics of upper mantle peridotites as illustrated by xenoliths from basalts. Journal of Petrology, 16(2): 454-487.

Meyer, H.O.A. \& Svisero, D.P. 1987. Mantle xenoliths in South América. In: Nixon, P.H. (ed.). Mantle Xenoliths, John Wiley \& Sons, New York, 844 p.

Meyer, H.O.A. \& Svisero, D.P. 1991. Limeira and Indaiá intrusions, Minas Gerais. Field Guide Book. $5^{\text {th }}$ International Kimberlite Conference, Araxá (Minas Gerais, Brazil). CPRM Special Publication 3/91: 49-55.

Mitchell, R.H. 1995. Kimberlites, orangeites and related rocks. Plenum Press, New York, 410p.

Morimoto, M. 1988. Mineralogical Magazine, 52: 535-550.

Navarro, M.S.; Andrade, S.; Ulbrich, H.H.G.J.; Gomes, C.B. \& Girardi, V.A.V. 2008. The direct determination of rare earth elements in basaltic and related rocks using ICP-MS: Testing the efficiency of microwave oven sample decomposition procedures. Geostandards and Geoanalytical Research, 32(2): 167-180.

Nicolas, A.; Lucazeau, F. \& Bayer, R. 1987. Peridotite xenoliths in Massif Central basalts, France: textural and geophysical evidence for astenospheric diapirism. In: Nixon, P.H. (ed.). Mantle xenoliths, John Wiley \& Sons, New York, 844 p.

Nixon, P.H. 1980. Kimberlites in the southwest Pacific. Nature, 287: 718-720.

Nixon, P.H. (ed.). 1987. Mantle xenoliths, John Wiley \& Sons, New York, 844 p.

Norman, M.D. 1998. Melting and metasomatism in the continental lithosphere: laser ablation ICPMS analysis of minerals in spinel Iherzolites from eastern Australia. Contributions to Mineralogy and Petrology, 130: 240-255.

Norrish, K. 1951. Priderite, a new mineral from the leucite-lamproites of the west Kimberley area, Western Australia. Mineralogical Magazine, 29: 496-501.

O'Neill, H.St.C. \& Wall, V.J. 1987. The olivine-orthopyroxene-spinel oxygen geobarometer, the nickel precipitation curve, and the oxygen fugacity of the Earth's upper mantle. Journal of Petrology, 28: 1169-1191.

Patiño-Douce, A.E. 1999. What do experiments tell us about the relative contributions for crust and mantle to the origin of granitic magmas? In: Castro, A.; Fernandez, C. \& Vigneresse, J.L. (eds.): Understanding Granites: Integrating New and Classical Techniques. Geological Society, London, Special Publication, 168: 55-75.

Pearson, D.G.; Canil, D. \& Shirey, S.B. 2003. Mantle samples included in volcanic rocks: xenoliths and diamonds. In: Carlson, R.W. (ed.), Treatise on Geochemistry, The Mantle and Core, 2: 171-275.

Peate, D.W. \& Hawkesworth, C.J. 1996. Lithospheric to asthenospheric transition in low-Ti flood basalts from Southern Paraná, Brazil. Chemical Geology, 127: 1-24.

Pisani, J.R.T.; Tainton, K.M.; Allan, A.F.; Silva, S.B. \& Miranda, J.V. 2001. Geology and exploration of the Brauna diamantiferous kimberlites, Serrinha Block, Bahia, Brazil. Revista Brasileira de Geociências, 31(4): 663-664. 
Princivalle, F.; Salviulo, G. \& Demarchi, G. 1994. Inter- and intra-crystalline temperature and pressure estimates on pyroxenes from NE Brazil mantle xenoliths. Contributions to Mineralogy and Petrology, 116: 1-6.

Riccomini, C.; Velázquez, V.F. \& Gomes, C.B. 2005. Tectonic controls of the Mesozoic and Cenozoic alkaline magmatism in central-southeastern Brazillian Platform. In: CominChiaramonti, P. \& C.B. Gomes (eds.), Mesozoic to Cenozoic Alkaline Magmatism in the Brazillian Platform. Edusp-Fapesp, 31-55.

Rieder, M.; Cavazzini, G.; D’Yakonov; Frank-Kamenetskii, V.A.; Gottardi, G.; Guggenheim, S.; Koval, P.V.; Müller, G.; Neiva, A.M.R.; Radoslovich, E.W.; Robert, J.; Sassi, F.P.; Takeda, H.; Weiss, Z. \& Wones, D.R.1998. Nomenclature of the micas. The Canadian Mineralogist, 36: 41-48.

Rivalenti, G.; Mazzucchelli, M.; Girardi, V.A.V.; Vannucci, R.; Barbieri, M.A.; Zanetti, A. \& Goldstein, S.L. 2000. Composition and processes of the mantle litosphere in northeastern Brazil and Fernando de Noronha: evidence from mantle xenoliths. Contributions to Mineralogy and Petrology, 138: 308-325.

Sial, A.N. 1977. Petrology and mineral chemistry of peridotite nodules included in Tertiary basaltic rocks of northeast Brazil. Geological Society American Bulletin, 88: 1173-1176.

Sial, A.N.; Fodor, R.V. \& Long, L.E. 1991. Peridotite xenoliths and Tertiary alkaline-basalts in Northeastern Brazil. In: Leonardos, O.H.; Meyer, H.O. \& Gaspar, J.C. (eds.). Field guide book of the $5^{\text {th }}$ International Kimberlite Conference, Araxá (Minas Gerais, Brazil). CPRM Special Publication 3/91, Brasília, Brasil.

Streckeisen, A.L. 1976. Classification of the common igneous rocks by means of their chemical composition: a provisional attempt. Neues Jahrbuch für Mineralogie, Monatshefte, 1: 115.

Sun, S.S. \& Mcdonough, W.F. 1989. Chemical and isotopic systematics of oceanic basalts: implications for mantle compositions and processes. In: Saunders, A.D. \& Norry, M.J. (eds.). Magmatism in the Ocean Basins. Geological Society Special Publication, 42, 313-346.

Svisero, D.P.; Meyer, H.O.A. \& Tsai, H.M. 1977. Kimberlite minerals from Vargem (Minas Gerais) and Redondão (Piauí) diatremes, Brazil, and garnet Iherzolite xenolith from Redondão Diatreme. Revista Brasileira de Geociências, 7: 1-13.

Svisero, D.P.; Meyer, H.O.A.; Haralyi, N.L.E. \& Hasui, Y. 1984. A note on the geology of some Brazilian kimberlites. Journal of Geology, 92: 331-338.

Svisero, D.P. \& Ulbrich, M.N.C. 1992. Mineralogia, petrografia e geologia do kimberlito Limeira e intrusões associadas, município de Monte Carmelo, Minas Gerais. Boletim IG-USP. Série Especial, São Paulo, 12: 127-129.

Toramaru, A. \& Fujii, N. 1986. Connectivity of melt phase in a partially molten peridotite. Journal of Geophysical Research, Solid Earth Planets, 9: 9239-9252.

Thompson, R.N.; Gibson, S.A.; Mitchell, J.G.; Dickin, A.P.; Leonardos, O.H.; Brod, J.A. \& Greenwood, J.C. 1998. Migrating Cretaceous-Eocene magmatism in the Serra do Mar alkaline Province, SE Brazil: melts from the deflected Trindade mantle plume? Journal of Petrology, 39: 1493-1526. 
Wells, P.R.A. 1977. Pyroxene thermometry in simple and complex systems. Contributions to Mineralogy and Petrology, 62: 129-139.

Wernick, E. \& Menezes, A.C. 2001. The Late Precambrian K-alkaline magmatism in the Ribeira Fold Belt: A case study of the Piracaia pluton, state of São Paulo, SE Brazil, and its potential mineralization (Cu, Cn, Gd). Asian Journal of Earth Sciences, 19: 347-373.

Weska, R. \& Svisero, D.P. 2001. Aspectos Geológicos de algumas intrusões kimberlíticas da região de Paranatinga, Mato Grosso. Revista Brasileira de Geociências, 31(4): 555-562.

Witt-Eickshen, G.E. \& Seck, H.A. 1991. Solubility of Ca and Al in orthopyroxene from spinel peridotite: na improved version of na empirical geothermometer. Contributions to Mineralogy and Petrology, 106: 431-439.

Witt-Eickshen, G. \& O'Neill, H.St.C. 2005. The effect of temperature on the equilibrium distribution of trace elements between clinopyroxene, orthopyroxene, olivine and spinel in upper mantle peridotite. Chemical Geology, 221: 65-101.

Wood, B.J. \& Blundy, J.D. 2003. Trace element partitioning under crustal and uppermost mantle conditions: The influence of ionic radius, cation charge, pressure and temperature. In: Carlson, R.W. (ed.). Treatise on geochemistry, The mantle and core, 2: 395-447.

Zanetti, A.; Mazzucchelli, M.; Rivalenti, G. \& Vannucci, R. 1999. The Finero phlogopiteperidotite massif: an example of subduction-related metasomatism. Contributions to Mineralogy and Petrology, 134: 107-122. 
Anexo 1: Resultados de análises químicas (elementos maiores) em cristais de olivina de xenólitos do manto de Ubatuba e Monte Carmelo..

\begin{tabular}{|c|c|c|c|c|c|c|c|c|c|c|c|c|c|c|c|c|}
\hline Amostra & Ln9g & Ln9g & Ln9g & Ln9g & Ln9g & Ln9g & Ln9g & Ln9g & Ln9h & Ln9h & Ln9h & Ln9h & Ln9xm1 & Ln9xm1 & Ln9xm1 & Ln9xm1 \\
\hline Cristal & 1 & 2 & 2 & 2 & 3 & 4 & 4 & 5 & 1 & 1 & 2 & 2 & 1 & 1 & 2 & 3 \\
\hline Posição & $\mathrm{n}$ & b & $\mathbf{n}$ & b & int & b & b & $n$ & $n$ & b & $\mathrm{n}$ & b & $\mathrm{n}$ & b & $\mathrm{n}$ & $\mathrm{n}$ \\
\hline $\mathrm{SiO}_{2}$ & 40,01 & 40,10 & 38,51 & 39,92 & 39,49 & 39,80 & 39,13 & 39,64 & 39,82 & 39,43 & 39,96 & 39,99 & 40,20 & 39,63 & 39,75 & 39,49 \\
\hline $\mathrm{TiO}_{2}$ & 0,01 & 0,00 & 0,04 & 0,00 & 0,00 & 0,07 & 0,11 & 0,11 & 0,12 & 0,05 & 0,03 & 0,01 & 0,00 & 0,00 & 0,00 & 0,00 \\
\hline $\mathrm{Al}_{2} \mathrm{O}_{3}$ & 0,03 & 0,00 & 0,04 & 0,00 & 0,00 & 0,00 & 0,00 & 0,00 & 0,06 & 0,02 & 0,00 & 0,02 & 0,00 & 0,01 & 0,00 & 0,02 \\
\hline $\mathrm{FeO}$ & 9,15 & 9,06 & 13,10 & 9,25 & 11,46 & 11,51 & 11,51 & 11,54 & 10,16 & 9,90 & 10,15 & 10,56 & 9,31 & 10,03 & 9,23 & 9,21 \\
\hline MnO & 0,13 & 0,08 & 0,18 & 0,18 & 0,23 & 0,23 & 0,22 & 0,19 & 0,13 & 0,10 & 0,14 & 0,09 & 0,14 & 0,12 & 0,12 & 0,12 \\
\hline MgO & 50,68 & 50,61 & 46,77 & 50,88 & 48,81 & 48,84 & 48,38 & 48,84 & 49,47 & 50,03 & 49,91 & 49,75 & 49,65 & 48,94 & 49,93 & 49,75 \\
\hline $\mathrm{CaO}$ & 0,00 & 0,02 & 0,27 & 0,02 & 0,03 & 0,01 & 0,02 & 0,01 & 0,02 & 0,03 & 0,02 & 0,02 & 0,02 & 0,06 & 0,02 & 0,02 \\
\hline $\mathrm{Na}_{2} \mathrm{O}$ & 0,00 & 0,00 & 0,03 & 0,01 & 0,00 & 0,02 & 0,03 & 0,02 & 0,00 & 0,00 & 0,00 & 0,01 & 0,02 & 0,02 & 0,00 & 0,05 \\
\hline $\mathrm{K}_{2} \mathrm{O}$ & 0,00 & 0,00 & 0,00 & 0,01 & 0,02 & 0,02 & 0,00 & 0,00 & 0,00 & 0,00 & 0,00 & 0,00 & 0,00 & 0,02 & 0,00 & 0,00 \\
\hline $\mathrm{Cr}_{2} \mathrm{O}_{3}$ & 0,01 & 0,02 & 0,08 & 0,00 & 0,01 & 0,03 & 0,00 & 0,03 & 0,03 & 0,02 & 0,03 & 0,03 & 0,03 & 0,03 & 0,00 & 0,00 \\
\hline $\mathrm{NiO}$ & 0,44 & 0,38 & 0,26 & 0,40 & 0,40 & 0,39 & 0,34 & 0,36 & 0,38 & 0,38 & 0,36 & 0,38 & 0,39 & 0,34 & 0,41 & 0,39 \\
\hline Total & 100,46 & 100,26 & 99,29 & 100,65 & 100,45 & 100,92 & 99,72 & 100,74 & 100,20 & 99,96 & 100,58 & 100,86 & 99,76 & 99,21 & 99,45 & 99,04 \\
\hline Si & 0,977 & 0,980 & 0,971 & 0,974 & 0,976 & 0,978 & 0,974 & 0,976 & 0,979 & 0,972 & 0,979 & 0,979 & 0,988 & 0,984 & 0,981 & 0,979 \\
\hline Al & 0,001 & 0,000 & 0,001 & 0,000 & 0,000 & 0,000 & 0,000 & 0,000 & 0,002 & 0,001 & 0,000 & 0,001 & 0,000 & 0,000 & 0,000 & 0,000 \\
\hline $\mathrm{Ti}$ & 0,000 & 0,000 & 0,001 & 0,000 & 0,000 & 0,001 & 0,002 & 0,002 & 0,002 & 0,001 & 0,001 & 0,000 & 0,000 & 0,000 & 0,000 & 0,000 \\
\hline $\mathrm{Fe}^{2+}$ & 0,187 & 0,185 & 0,276 & 0,189 & 0,237 & 0,237 & 0,240 & 0,238 & 0,209 & 0,204 & 0,208 & 0,216 & 0,191 & 0,208 & 0,191 & 0,191 \\
\hline Mn & 0,003 & 0,002 & 0,004 & 0,004 & 0,005 & 0,005 & 0,005 & 0,004 & 0,003 & 0,002 & 0,003 & 0,002 & 0,003 & 0,003 & 0,002 & 0,002 \\
\hline Mg & 1,845 & 1,844 & 1,758 & 1,851 & 1,798 & 1,790 & 1,796 & 1,793 & 1,814 & 1,838 & 1,822 & 1,815 & 1,820 & 1,811 & 1,837 & 1,839 \\
\hline $\mathrm{Ca}$ & 0,000 & 0,000 & 0,007 & 0,000 & 0,001 & 0,000 & 0,000 & 0,000 & 0,000 & 0,001 & 0,001 & 0,000 & 0,001 & 0,002 & 0,001 & 0,001 \\
\hline $\mathrm{Na}$ & 0,000 & 0,000 & 0,001 & 0,001 & 0,000 & 0,001 & 0,001 & 0,001 & 0,000 & 0,000 & 0,000 & 0,000 & 0,001 & 0,001 & 0,000 & 0,003 \\
\hline K & 0,000 & 0,000 & 0,000 & 0,000 & 0,001 & 0,001 & 0,000 & 0,000 & 0,000 & 0,000 & 0,000 & 0,000 & 0,000 & 0,001 & 0,000 & 0,000 \\
\hline $\mathrm{Ni}$ & 0,009 & 0,008 & 0,005 & 0,008 & 0,008 & 0,008 & 0,007 & 0,007 & 0,008 & 0,007 & 0,007 & 0,007 & 0,008 & 0,007 & 0,008 & 0,008 \\
\hline Cátions & 3,022 & 3,019 & 3,024 & 3,027 & 3,026 & 3,021 & 3,025 & 3,021 & 3,017 & 3,026 & 3,021 & 3,020 & 3,012 & 3,017 & 3,020 & 3,023 \\
\hline $\mathrm{Fa}$ & 0,090 & 0,090 & 0,140 & 0,090 & 0,120 & 0,120 & 0,120 & 0,120 & 0,100 & 0,100 & 0,100 & 0,110 & 0,090 & 0,100 & 0,090 & 0,090 \\
\hline Fo & 0,910 & 0,910 & 0,860 & 0,910 & 0,880 & 0,880 & 0,880 & 0,880 & 0,900 & 0,900 & 0,900 & 0,890 & 0,910 & 0,900 & 0,910 & 0,910 \\
\hline
\end{tabular}

$n=$ núcleo, $b=$ borda, int= entre núcleo e borda. Fórmula estrutural calculada com base em 4 oxigênios e 3 cátions. 
Anexo 1: Análises químicas em olivina (continuação).

\begin{tabular}{|c|c|c|c|c|c|c|c|c|c|c|c|c|c|c|}
\hline Amostra & Ln9xm1 & Ln9xm2 & Ln9xm2 & Ln9xm2 & Ln9xm2 & Ln9xm2 & Ln9xm2 & Ln9xm3 & Ln9xm3 & Ln9xm3 & Ln9xm3 & Ln9xm3 & KIxm1 & KIxm1 \\
\hline Cristal & 3 & 1 & 1 & 2 & 2 & 3 & 4 & 1 & 1 & 2 & 3 & 4 & 1 & 2 \\
\hline Posição & b & $\mathrm{n}$ & b & $\mathrm{n}$ & b & $\mathbf{n}$ & $\mathrm{n}$ & $\mathrm{n}$ & b & b & int & $n$ & b & int \\
\hline $\mathrm{SiO}_{2}$ & 39,10 & 40,59 & 39,97 & 40,55 & 40,75 & 40,83 & 40,81 & 40,08 & 39,61 & 39,57 & 39,47 & 40,01 & 41,03 & 41,50 \\
\hline $\mathrm{TiO}_{2}$ & 0,00 & 0,00 & 0,01 & 0,02 & 0,00 & 0,00 & 0,00 & 0,00 & 0,01 & 0,00 & 0,00 & 0,00 & 0,00 & 0,00 \\
\hline $\mathrm{Al}_{2} \mathrm{O}_{3}$ & 0,00 & 0,02 & 0,01 & 0,01 & 0,04 & 0,00 & 0,02 & 0,00 & 0,00 & 0,01 & 0,01 & 0,01 & 0,01 & 0,03 \\
\hline $\mathrm{FeO}$ & 9,17 & 11,51 & 10,54 & 11,16 & 11,44 & 10,22 & 11,05 & 10,32 & 10,20 & 10,16 & 10,22 & 10,37 & 8,31 & 7,96 \\
\hline Mno & 0,10 & 0,21 & 0,23 & 0,21 & 0,28 & 0,22 & 0,20 & 0,18 & 0,10 & 0,12 & 0,21 & 0,15 & 0,12 & 0,15 \\
\hline MgO & 50,56 & 48,04 & 48,01 & 48,15 & 47,71 & 48,37 & 48,13 & 48,86 & 48,94 & 48,90 & 48,92 & 48,85 & 50,79 & 50,74 \\
\hline $\mathrm{CaO}$ & 0,05 & 0,02 & 0,06 & 0,03 & 0,04 & 0,09 & 0,07 & 0,01 & 0,01 & 0,01 & 0,00 & 0,02 & 0,00 & 0,02 \\
\hline $\mathrm{Na}_{2} \mathrm{O}$ & 0,00 & 0,00 & 0,02 & 0,00 & 0,00 & 0,01 & 0,00 & 0,00 & 0,00 & 0,00 & 0,00 & 0,01 & 0,01 & 0,00 \\
\hline $\mathrm{K}_{2} \mathrm{O}$ & 0,00 & 0,01 & 0,00 & 0,00 & 0,02 & 0,01 & 0,01 & 0,00 & 0,00 & 0,00 & 0,00 & 0,00 & 0,00 & 0,00 \\
\hline $\mathrm{Cr}_{2} \mathrm{O}_{3}$ & 0,01 & 0,05 & 0,03 & 0,04 & 0,01 & 0,01 & 0,03 & 0,00 & 0,00 & 0,00 & 0,02 & 0,00 & 0,01 & 0,02 \\
\hline $\mathrm{NiO}$ & 0,42 & 0,32 & 0,30 & 0,31 & 0,32 & 0,25 & 0,24 & 0,40 & 0,40 & 0,41 & 0,37 & 0,39 & 0,40 & 0,40 \\
\hline Total & 99,41 & 100,76 & 99,17 & 100,48 & 100,62 & 100,00 & 100,56 & 99,86 & 99,28 & 99,18 & 99,21 & 99,81 & 100,68 & 100,82 \\
\hline Si & 0,967 & 0,996 & 0,994 & 0,996 & 1,001 & 1,003 & 1,001 & 0,989 & 0,983 & 0,983 & 0,981 & 0,988 & 0,994 & 1,001 \\
\hline Al & 0,000 & 0,001 & 0,000 & 0,000 & 0,001 & 0,000 & 0,001 & 0,000 & 0,000 & 0,000 & 0,000 & 0,000 & 0,000 & 0,001 \\
\hline $\mathrm{Ti}$ & 0,000 & 0,000 & 0,000 & 0,000 & 0,000 & 0,000 & 0,000 & 0,000 & 0,000 & 0,000 & 0,000 & 0,000 & 0,000 & 0,000 \\
\hline $\mathrm{Fe}^{2+}$ & 0,190 & 0,236 & 0,219 & 0,229 & 0,235 & 0,210 & 0,227 & 0,213 & 0,212 & 0,211 & 0,212 & 0,214 & 0,168 & 0,161 \\
\hline Mn & 0,002 & 0,004 & 0,005 & 0,004 & 0,006 & 0,005 & 0,004 & 0,004 & 0,002 & 0,003 & 0,004 & 0,003 & 0,002 & 0,003 \\
\hline Mg & 1,864 & 1,758 & 1,779 & 1,764 & 1,747 & 1,771 & 1,759 & 1,797 & 1,811 & 1,811 & 1,813 & 1,798 & 1,834 & 1,824 \\
\hline $\mathrm{Ca}$ & 0,001 & 0,001 & 0,002 & 0,001 & 0,001 & 0,002 & 0,002 & 0,000 & 0,000 & 0,000 & 0,000 & 0,000 & 0,000 & 0,000 \\
\hline $\mathrm{Na}$ & 0,000 & 0,000 & 0,001 & 0,000 & 0,000 & 0,000 & 0,000 & 0,000 & 0,000 & 0,000 & 0,000 & 0,001 & 0,001 & 0,000 \\
\hline K & 0,000 & 0,000 & 0,000 & 0,000 & 0,001 & 0,000 & 0,000 & 0,000 & 0,000 & 0,000 & 0,000 & 0,000 & 0,000 & 0,000 \\
\hline $\mathrm{Ni}$ & 0,008 & 0,006 & 0,006 & 0,006 & 0,006 & 0,005 & 0,005 & 0,008 & 0,008 & 0,008 & 0,007 & 0,008 & 0,008 & 0,008 \\
\hline Cátions & 3,032 & 3,002 & 3,006 & 3,000 & 2,998 & 2,996 & 2,999 & 3,011 & 3,016 & 3,016 & 3,017 & 3,012 & 3,007 & 2,998 \\
\hline $\mathrm{Fa}$ & 0,090 & 0,120 & 0,110 & 0,110 & 0,120 & 0,110 & 0,110 & 0,110 & 0,100 & 0,100 & 0,100 & 0,110 & 0,080 & 0,080 \\
\hline Fo & 0,910 & 0,880 & 0,890 & 0,890 & 0,880 & 0,890 & 0,890 & 0,890 & 0,900 & 0,900 & 0,900 & 0,890 & 0,920 & 0,920 \\
\hline
\end{tabular}

$n=$ núcleo, $b=$ borda, int= entre núcleo e borda. Fórmula estrutural calculada com base em 4 oxigênios e 3 cátions. 
Anexo 1: Análises químicas em olivina (continuação).

\begin{tabular}{|c|c|c|c|c|c|c|c|c|c|c|c|c|c|c|}
\hline Amostra & KIxm1 & KIxm2 & KIxm2 & KIxm2 & KIxm2 & $\mathrm{KIxm} 2$ & KIxm2 & $\mathrm{KIxm} 2$ & KIxm2 & KIxm3 & KIxm3 & KIxm3 & KIxm3 & KIxm3 \\
\hline Cristal & 2 & 1 & 2 & 2 & 3 & 4 & 4 & 5 & 5 & 1 & 1 & 2 & 2 & 3 \\
\hline Posição & int & $\mathrm{n}$ & $\mathrm{n}$ & b & $\mathrm{n}$ & $\mathrm{n}$ & b & $\mathrm{n}$ & b & b & $\mathrm{n}$ & b & $\mathrm{n}$ & b \\
\hline $\mathrm{SiO}_{2}$ & 40,93 & 40,59 & 40,51 & 40,35 & 40,02 & 40,30 & 40,67 & 40,75 & 40,64 & 39,70 & 39,40 & 38,37 & 39,23 & 38,04 \\
\hline $\mathrm{TiO}_{2}$ & 0,00 & 0,04 & 0,00 & 0,00 & 0,04 & 0,03 & 0,02 & 0,00 & 0,00 & 0,21 & 0,04 & 0,06 & 0,02 & 0,19 \\
\hline $\mathrm{Al}_{2} \mathrm{O}_{3}$ & 0,00 & 0,03 & 0,01 & 0,02 & 0,02 & 0,01 & 0,01 & 0,00 & 0,00 & 0,02 & 0,02 & 0,37 & 0,00 & 0,00 \\
\hline $\mathrm{FeO}$ & 8,17 & 11,84 & 11,93 & 11,63 & 11,76 & 11,88 & 11,37 & 10,67 & 10,78 & 9,21 & 9,51 & 17,97 & 9,98 & 19,66 \\
\hline MnO & 0,16 & 0,14 & 0,15 & 0,19 & 0,14 & 0,14 & 0,13 & 0,11 & 0,16 & 0,21 & 0,24 & 0,35 & 0,26 & 0,34 \\
\hline MgO & 50,40 & 47,51 & 47,13 & 47,53 & 47,75 & 47,37 & 47,30 & 48,25 & 48,15 & 48,48 & 48,68 & 42,85 & 49,00 & 41,48 \\
\hline $\mathrm{CaO}$ & 0,04 & 0,05 & 0,06 & 0,09 & 0,05 & 0,06 & 0,04 & 0,00 & 0,05 & 1,14 & 1,11 & 0,13 & 0,45 & 0,17 \\
\hline $\mathrm{Na}_{2} \mathrm{O}$ & 0,01 & 0,00 & 0,02 & 0,01 & 0,00 & 0,01 & 0,00 & 0,00 & 0,00 & 0,01 & 0,02 & 0,04 & 0,02 & 0,02 \\
\hline $\mathrm{K}_{2} \mathrm{O}$ & 0,00 & 0,00 & 0,01 & 0,00 & 0,03 & 0,01 & 0,00 & 0,00 & 0,01 & 0,00 & 0,00 & 0,00 & 0,00 & 0,02 \\
\hline $\mathrm{Cr}_{2} \mathrm{O}_{3}$ & 0,00 & 0,03 & 0,02 & 0,03 & 0,06 & 0,04 & 0,01 & 0,00 & 0,02 & 0,03 & 0,07 & 0,06 & 0,08 & 0,10 \\
\hline $\mathrm{NiO}$ & 0,42 & 0,36 & 0,37 & 0,32 & 0,39 & 0,38 & 0,37 & 0,34 & 0,29 & 0,08 & 0,09 & 0,10 & 0,04 & 0,10 \\
\hline Total & 100,11 & 100,58 & 100,21 & 100,16 & 100,27 & 100,21 & 99,93 & 100,11 & 100,09 & 99,09 & 99,19 & 100,28 & 99,08 & 100,10 \\
\hline Si & 0,996 & 0,999 & 1,001 & 0,997 & 0,990 & 0,997 & 1,005 & 1,002 & 1,000 & 0,985 & 0,979 & 0,977 & 0,976 & 0,980 \\
\hline Al & 0,000 & 0,001 & 0,000 & 0,001 & 0,001 & 0,000 & 0,000 & 0,000 & 0,000 & 0,000 & 0,001 & 0,011 & 0,000 & 0,000 \\
\hline $\mathrm{Ti}$ & 0,000 & 0,001 & 0,000 & 0,000 & 0,001 & 0,001 & 0,000 & 0,000 & 0,000 & 0,004 & 0,001 & 0,001 & 0,000 & 0,004 \\
\hline $\mathrm{Fe}^{2+}$ & 0,166 & 0,244 & 0,247 & 0,240 & 0,243 & 0,246 & 0,235 & 0,219 & 0,222 & 0,191 & 0,198 & 0,383 & 0,208 & 0,423 \\
\hline Mn & 0,003 & 0,003 & 0,003 & 0,004 & 0,003 & 0,003 & 0,003 & 0,002 & 0,003 & 0,004 & 0,005 & 0,007 & 0,006 & 0,007 \\
\hline Mg & 1,829 & 1,743 & 1,737 & 1,751 & 1,761 & 1,746 & 1,742 & 1,768 & 1,767 & 1,793 & 1,803 & 1,628 & 1,818 & 1,592 \\
\hline $\mathrm{Ca}$ & 0,001 & 0,001 & 0,002 & 0,002 & 0,001 & 0,001 & 0,001 & 0,000 & 0,001 & 0,030 & 0,030 & 0,003 & 0,012 & 0,005 \\
\hline $\mathrm{Na}$ & 0,000 & 0,000 & 0,001 & 0,000 & 0,000 & 0,000 & 0,000 & 0,000 & 0,000 & 0,001 & 0,001 & 0,002 & 0,001 & 0,001 \\
\hline K & 0,000 & 0,000 & 0,000 & 0,000 & 0,001 & 0,000 & 0,000 & 0,000 & 0,000 & 0,000 & 0,000 & 0,000 & 0,000 & 0,001 \\
\hline $\mathrm{Ni}$ & 0,008 & 0,007 & 0,007 & 0,006 & 0,008 & 0,008 & 0,007 & 0,007 & 0,006 & 0,002 & 0,002 & 0,002 & 0,001 & 0,002 \\
\hline Cátions & 3,003 & 2,999 & 2,998 & 3,001 & 3,009 & 3,002 & 2,993 & 2,998 & 2,999 & 3,010 & 3,020 & 3,014 & 3,022 & 3,015 \\
\hline $\mathbf{F a}$ & 0,080 & 0,120 & 0,120 & 0,120 & 0,120 & 0,120 & 0,120 & 0,110 & 0,110 & 0,100 & 0,100 & 0,190 & 0,100 & 0,210 \\
\hline Fo & 0,920 & 0,880 & 0,880 & 0,880 & 0,880 & 0,880 & 0,880 & 0,890 & 0,890 & 0,900 & 0,900 & 0,810 & 0,900 & 0,790 \\
\hline
\end{tabular}

$n=$ núcleo, $b=$ borda, int= entre núcleo e borda. Fórmula estrutural calculada com base em 4 oxigênios e 3 cátions. 
Anexo 2: Resultados de análises químicas (elementos maiores) em cristais de ortopiroxênio de xenólitos do manto de Ubatuba e Monte Carmelo.

\begin{tabular}{|c|c|c|c|c|c|c|c|c|c|c|c|c|c|c|c|}
\hline Amostra & Ln9g & Ln9g & Ln9h & Ln9xm2 & Ln9xm2 & Ln9xm3 & Ln9xm3 & Ln9xm3 & Ln9xm3 & Ln9xm3 & Ln9xm3 & Ln9xm3 & Ln9xm1 & Ln9xm1 & Ln9xm1 \\
\hline Cristal & 1 & 1 & 1 & 2 & 2 & 1 & 2 & 2 & 3 & 3 & 4 & 5 & 1 & 2 & 3 \\
\hline Posição & b & $n$ & int & b & int & b & b & $n$ & b & $n$ & $n$ & $n$ & $n$ & $n$ & Int \\
\hline $\mathrm{SiO}_{2}$ & 54,15 & 54,86 & 55,82 & 57,37 & 55,36 & 54,29 & 55,13 & 54,85 & 55,05 & 54,47 & 55,12 & 55,26 & 55,50 & 54,68 & 55,67 \\
\hline $\mathrm{TiO}_{2}$ & 0,07 & 0,03 & 0,19 & 0,00 & 0,00 & 0,13 & 0,11 & 0,12 & 0,11 & 0,08 & 0,16 & 0,22 & 0,09 & 0,07 & 0,00 \\
\hline $\mathrm{Al}_{2} \mathrm{O}_{3}$ & 3,32 & 3,59 & 4,15 & 1,65 & 2,42 & 4,73 & 4,32 & 4,55 & 3,95 & 4,91 & 4,52 & 4,62 & 3,98 & 4,38 & 3,59 \\
\hline $\mathrm{FeO}$ & 6,28 & 5,88 & 6,49 & 7,02 & 6,87 & 6,73 & 6,69 & 6,64 & 6,84 & 6,55 & 6,83 & 6,56 & 6,18 & 6,19 & 6,13 \\
\hline Mno & 0,13 & 0,14 & 0,16 & 0,22 & 0,19 & 0,13 & 0,19 & 0,12 & 0,13 & 0,13 & 0,15 & 0,16 & 0,19 & 0,14 & 0,13 \\
\hline MgO & 34,69 & 34,08 & 33,72 & 33,39 & 33,71 & 32,53 & 32,68 & 32,42 & 32,62 & 32,63 & 33,01 & 33,00 & 33,03 & 32,73 & 33,13 \\
\hline $\mathrm{CaO}$ & 0,48 & 1,01 & 0,33 & 0,60 & 0,35 & 0,60 & 0,49 & 0,55 & 0,33 & 0,41 & 0,24 & 0,73 & 0,38 & 0,54 & 0,39 \\
\hline $\mathrm{Na}_{2} \mathrm{O}$ & 0,04 & 0,06 & 0,07 & 0,35 & 0,09 & 0,04 & 0,04 & 0,08 & 0,02 & 0,04 & 0,01 & 0,04 & 0,04 & 0,03 & 0,03 \\
\hline $\mathrm{K}_{2} \mathrm{O}$ & 0,01 & 0,00 & 0,00 & 0,14 & 0,00 & 0,00 & 0,00 & 0,00 & 0,01 & 0,00 & 0,00 & 0,00 & 0,00 & 0,00 & 0,01 \\
\hline $\mathrm{Cr}_{2} \mathrm{O}_{3}$ & 0,59 & 0,70 & 0,28 & 0,16 & 0,27 & 0,26 & 0,27 & 0,28 & 0,24 & 0,31 & 0,29 & 0,25 & 0,44 & 0,45 & 0,32 \\
\hline Total & 99,74 & 100,33 & 101,21 & 100,90 & 99,25 & 99,44 & 99,91 & 99,61 & 99,30 & 99,53 & 100,33 & 100,84 & 99,83 & 99,20 & 99,41 \\
\hline TSi & 1,863 & 1,881 & 1,902 & 1,965 & 1,923 & 1,886 & 1,908 & 1,904 & 1,917 & 1,890 & 1,899 & 1,894 & 1,920 & 1,902 & 1,932 \\
\hline Tal & 0,134 & 0,119 & 0,098 & 0,035 & 0,077 & 0,114 & 0,092 & 0,096 & 0,083 & 0,110 & 0,101 & 0,106 & 0,080 & 0,098 & 0,068 \\
\hline TFe3 & 0,002 & 0,000 & 0,000 & 0,000 & 0,000 & 0,000 & 0,000 & 0,000 & 0,000 & 0,000 & 0,000 & 0,000 & 0,000 & 0,000 & 0,000 \\
\hline M1Al & 0,000 & 0,025 & 0,069 & 0,031 & 0,022 & 0,080 & 0,084 & 0,090 & 0,080 & 0,090 & 0,082 & 0,080 & 0,082 & 0,082 & 0,078 \\
\hline M1Ti & 0,002 & 0,001 & 0,005 & 0,000 & 0,000 & 0,003 & 0,003 & 0,003 & 0,003 & 0,002 & 0,004 & 0,006 & 0,002 & 0,002 & 0,000 \\
\hline M1Fe3 & 0,119 & 0,077 & 0,016 & 0,028 & 0,053 & 0,023 & 0,000 & 0,000 & 0,000 & 0,009 & 0,003 & 0,010 & 0,000 & 0,002 & 0,000 \\
\hline M1Fe2 & 0,000 & 0,000 & 0,000 & 0,000 & 0,000 & 0,000 & 0,000 & 0,000 & 0,000 & 0,000 & 0,000 & 0,000 & 0,000 & 0,000 & 0,000 \\
\hline $\mathrm{M} 1 \mathrm{Cr}$ & 0,016 & 0,019 & 0,008 & 0,004 & 0,007 & 0,007 & 0,007 & 0,008 & 0,007 & 0,008 & 0,008 & 0,007 & 0,012 & 0,012 & 0,009 \\
\hline M1Mg & 0,863 & 0,878 & 0,903 & 0,936 & 0,918 & 0,887 & 0,906 & 0,899 & 0,911 & 0,890 & 0,903 & 0,898 & 0,904 & 0,903 & 0,913 \\
\hline M1Ni & 0,000 & 0,000 & 0,000 & 0,000 & 0,000 & 0,000 & 0,000 & 0,000 & 0,000 & 0,000 & 0,000 & 0,000 & 0,000 & 0,000 & 0,000 \\
\hline M2Mg & 0,917 & 0,864 & 0,810 & 0,769 & 0,828 & 0,798 & 0,780 & 0,778 & 0,783 & 0,797 & 0,792 & 0,788 & 0,799 & 0,795 & 0,801 \\
\hline M2Fe2 & 0,059 & 0,092 & 0,169 & 0,173 & 0,147 & 0,173 & 0,194 & 0,193 & 0,199 & 0,181 & 0,194 & 0,178 & 0,179 & 0,179 & 0,178 \\
\hline M2Mn & 0,004 & 0,004 & 0,005 & 0,006 & 0,006 & 0,004 & 0,006 & 0,004 & 0,004 & 0,004 & 0,004 & 0,005 & 0,006 & 0,004 & 0,004 \\
\hline $\mathrm{M} 2 \mathrm{Ca}$ & 0,018 & 0,037 & 0,012 & 0,022 & 0,013 & 0,022 & 0,018 & 0,021 & 0,012 & 0,015 & 0,009 & 0,027 & 0,014 & 0,020 & 0,015 \\
\hline $\mathrm{M} 2 \mathrm{Na}$ & 0,002 & 0,004 & 0,004 & 0,024 & 0,006 & 0,003 & 0,002 & 0,005 & 0,001 & 0,003 & 0,001 & 0,002 & 0,002 & 0,002 & 0,002 \\
\hline M2K & 0,000 & 0,000 & 0,000 & 0,006 & 0,000 & 0,000 & 0,000 & 0,000 & 0,000 & 0,000 & 0,000 & 0,000 & 0,000 & 0,000 & 0,000 \\
\hline Cátions & 4,000 & 4,000 & 4,000 & 3,994 & 4,000 & 4,000 & 4,000 & 4,000 & 4,000 & 4,000 & 4,000 & 4,000 & 4,000 & 4,000 & 4,000 \\
\hline
\end{tabular}

$n=$ núcleo, $b=$ borda, int= entre núcleo e borda. Fórmula estrutural calculada com base em 6 oxigênios e 4 cátions. 
Anexo 2: Análises químicas em ortopiroxênio (continuação)..

\begin{tabular}{|c|c|c|c|c|c|c|c|c|c|c|c|c|c|c|c|}
\hline Amostra & Ln9g & Ln9g & Ln9h & Ln9xm2 & Ln9xm2 & Ln9xm3 & Ln9xm3 & Ln9xm3 & Ln9xm3 & Ln9xm3 & Ln9xm3 & Ln9xm3 & Ln9xm1 & Ln9xm1 & Ln9xm1 \\
\hline Cristal & 1 & 1 & 1 & 2 & 2 & 1 & 2 & 2 & 3 & 3 & 4 & 5 & 1 & 2 & 3 \\
\hline Posição & b & $\mathrm{n}$ & int & b & int & b & b & $\mathrm{n}$ & b & $\mathrm{n}$ & $\mathbf{n}$ & $\mathrm{n}$ & $\mathrm{n}$ & $\mathbf{n}$ & Int \\
\hline $\mathrm{Ca}$ & 0,943 & 1,981 & 0,631 & 1,163 & 0,680 & 1,186 & 0,960 & 1,088 & 0,643 & 0,798 & 0,468 & 1,408 & 0,746 & 1,067 & 0,763 \\
\hline Mg & 95,664 & 92,923 & 90,213 & 89,446 & 91,347 & 89,438 & 88,578 & 88,557 & 88,716 & 89,411 & 89,104 & 88,948 & 89,560 & 89,315 & 89,719 \\
\hline Fe2_Mn & 3,393 & 5,096 & 9,156 & 9,391 & 7,973 & 9,377 & 10,462 & 10,355 & 10,641 & 9,791 & 10,428 & 9,644 & 9,694 & 9,618 & 9,518 \\
\hline JD1 & 0,000 & 0,187 & 0,224 & 1,519 & 0,311 & 0,157 & 0,125 & 0,275 & 0,073 & 0,136 & 0,027 & 0,122 & 0,126 & 0,096 & 0,134 \\
\hline AE1 & 0,138 & 0,000 & 0,000 & 0,000 & 0,000 & 0,000 & 0,000 & 0,000 & 0,000 & 0,000 & 0,000 & 0,000 & 0,000 & 0,000 & 0,000 \\
\hline CFTS1 & 6,694 & 4,902 & 1,176 & 1,685 & 3,037 & 1,508 & 0,371 & 0,385 & 0,337 & 0,889 & 0,539 & 0,847 & 0,605 & 0,696 & 0,450 \\
\hline CTTS1 & 0,097 & 0,033 & 0,247 & 0,000 & 0,000 & 0,176 & 0,142 & 0,156 & 0,149 & 0,111 & 0,205 & 0,291 & 0,122 & 0,091 & 0,000 \\
\hline CATS1 & 0,000 & 1,115 & 3,246 & 0,102 & 0,824 & 3,885 & 4,119 & 4,288 & 3,945 & 4,432 & 4,113 & 3,948 & 3,941 & 4,042 & 3,466 \\
\hline WO1 & 0,000 & 0,000 & 0,000 & 0,000 & 0,000 & 0,000 & 0,000 & 0,000 & 0,000 & 0,000 & 0,000 & 0,000 & 0,000 & 0,000 & 0,000 \\
\hline EN1 & 90,061 & 89,078 & 86,558 & 87,800 & 88,391 & 85,502 & 85,433 & 85,120 & 85,440 & 85,290 & 85,351 & 85,733 & 86,161 & 86,022 & 86,926 \\
\hline FS1 & 3,010 & 4,685 & 8,549 & 8,894 & 7,437 & 8,771 & 9,810 & 9,774 & 10,056 & 9,142 & 9,766 & 9,059 & 9,044 & 9,054 & 9,024 \\
\hline Q & 1,857 & 1,870 & 1,894 & 1,900 & 1,906 & 1,880 & 1,898 & 1,890 & 1,905 & 1,883 & 1,898 & 1,891 & 1,896 & 1,897 & 1,906 \\
\hline $\mathbf{J}$ & 0,005 & 0,007 & 0,009 & 0,047 & 0,012 & 0,006 & 0,005 & 0,010 & 0,002 & 0,005 & 0,001 & 0,005 & 0,005 & 0,004 & 0,004 \\
\hline wo & 0,886 & 1,903 & 0,626 & 1,146 & 0,662 & 1,171 & 0,960 & 1,088 & 0,643 & 0,794 & 0,467 & 1,401 & 0,746 & 1,066 & 0,763 \\
\hline EN & 89,812 & 89,260 & 89,477 & 88,134 & 88,901 & 88,372 & 88,578 & 88,557 & 88,716 & 88,976 & 88,972 & 88,489 & 89,560 & 89,245 & 89,719 \\
\hline FS & 9,302 & 8,837 & 9,898 & 10,720 & 10,437 & 10,456 & 10,462 & 10,355 & 10,641 & 10,230 & 10,561 & 10,110 & 9,694 & 9,689 & 9,518 \\
\hline WEF & 99,735 & 99,611 & 99,536 & 97,593 & 99,370 & 99,686 & 99,747 & 99,449 & 99,873 & 99,716 & 99,944 & 99,748 & 99,740 & 99,802 & 99,775 \\
\hline JD & 0,000 & 0,097 & 0,378 & 1,266 & 0,189 & 0,244 & 0,253 & 0,551 & 0,127 & 0,258 & 0,054 & 0,224 & 0,260 & 0,195 & 0,225 \\
\hline$A E$ & 0,265 & 0,292 & 0,086 & 1,141 & 0,442 & 0,070 & 0,000 & 0,000 & 0,000 & 0,026 & 0,002 & 0,028 & 0,000 & 0,004 & 0,000 \\
\hline $100 \# M g$ & 90,82 & 91,16 & 90,25 & 89,45 & 89,72 & 89,58 & 89,68 & 89,68 & 89,49 & 89,88 & 89,59 & 89,97 & 90,49 & 90,37 & 90,59 \\
\hline
\end{tabular}

$n=$ núcleo, $b=$ borda, int= entre núcleo e borda. Fórmula estrutural calculada com base em 6 oxigênios e 4 cátions. 
Anexo 2: Análises químicas em ortopiroxênio (continuação).

\begin{tabular}{|c|c|c|c|c|c|c|c|c|c|c|c|}
\hline Amostra & KIxm1 & KIxm1 & KIxm1 & KIxm1 & KIxm1 & KIxm1 & KIxm1 & KIxm1 & KIxm2 & KIxm2 & Klxm2 \\
\hline Cristal & 1 & 1 & 2 & 2 & 3 & 3 & 4 & 4 & 1 & 1 & 2 \\
\hline Posição & $n$ & int & $n$ & b & $\mathrm{n}$ & b & $n$ & b & $n$ & b & $\mathrm{n}$ \\
\hline $\mathrm{SiO}_{2}$ & 56,52 & 55,99 & 55,34 & 56,49 & 56,15 & 56,15 & 55,63 & 55,31 & 56,97 & 58,02 & 56,93 \\
\hline $\mathrm{TiO}_{2}$ & 0,00 & 0,04 & 0,03 & 0,02 & 0,01 & 0,01 & 0,00 & 0,04 & 0,25 & 0,08 & 0,25 \\
\hline $\mathrm{Al}_{2} \mathrm{O}_{3}$ & 2,45 & 2,62 & 2,49 & 2,32 & 2,65 & 2,67 & 2,95 & 2,51 & 0,32 & 0,32 & 0,37 \\
\hline $\mathrm{FeO}$ & 5,61 & 5,80 & 5,56 & 5,77 & 5,64 & 5,52 & 5,53 & 5,81 & 6,94 & 6,40 & 6,97 \\
\hline MnO & 0,14 & 0,13 & 0,11 & 0,12 & 0,14 & 0,12 & 0,16 & 0,13 & 0,18 & 0,11 & 0,19 \\
\hline MgO & 34,91 & 34,94 & 35,09 & 35,39 & 35,02 & 34,97 & 35,04 & 34,86 & 34,65 & 34,92 & 34,21 \\
\hline $\mathrm{CaO}$ & 0,43 & 0,49 & 0,34 & 0,44 & 0,49 & 0,51 & 0,38 & 0,48 & 0,82 & 0,75 & 0,74 \\
\hline $\mathrm{Na}_{2} \mathrm{O}$ & 0,06 & 0,05 & 0,04 & 0,03 & 0,03 & 0,02 & 0,00 & 0,00 & 0,10 & 0,08 & 0,10 \\
\hline $\mathrm{K}_{2} \mathrm{O}$ & 0,12 & 0,00 & 0,00 & 0,00 & 0,00 & 0,00 & 0,00 & 0,00 & 0,01 & 0,01 & 0,09 \\
\hline $\mathrm{Cr}_{2} \mathrm{O}_{3}$ & 0,41 & 0,44 & 0,46 & 0,40 & 0,45 & 0,46 & 0,47 & 0,37 & 0,32 & 0,30 & 0,26 \\
\hline Total & 100,63 & 100,49 & 99,45 & 100,98 & 100,59 & 100,42 & 100,16 & 99,51 & 100,54 & 100,99 & 100,10 \\
\hline TSi & 1,927 & 1,912 & 1,906 & 1,919 & 1,915 & 1,918 & 1,904 & 1,907 & 1,957 & 1,981 & 1,966 \\
\hline Tal & 0,073 & 0,088 & 0,094 & 0,081 & 0,085 & 0,082 & 0,096 & 0,093 & 0,013 & 0,013 & 0,015 \\
\hline TFe3 & 0,000 & 0,000 & 0,000 & 0,000 & 0,000 & 0,000 & 0,000 & 0,000 & 0,030 & 0,006 & 0,019 \\
\hline M1AI & 0,026 & 0,018 & 0,007 & 0,012 & 0,021 & 0,026 & 0,023 & 0,009 & 0,000 & 0,000 & 0,000 \\
\hline M1Ti & 0,000 & 0,001 & 0,001 & 0,000 & 0,000 & 0,000 & 0,000 & 0,001 & 0,006 & 0,002 & 0,006 \\
\hline M1Fe3 & 0,045 & 0,059 & 0,076 & 0,060 & 0,052 & 0,044 & 0,060 & 0,072 & 0,029 & 0,012 & 0,025 \\
\hline M1Fe2 & 0,000 & 0,000 & 0,000 & 0,000 & 0,000 & 0,000 & 0,000 & 0,000 & 0,000 & 0,000 & 0,000 \\
\hline $\mathrm{M} 1 \mathrm{Cr}$ & 0,011 & 0,012 & 0,013 & 0,011 & 0,012 & 0,012 & 0,013 & 0,010 & 0,009 & 0,008 & 0,007 \\
\hline M1Mg & 0,919 & 0,911 & 0,904 & 0,917 & 0,914 & 0,917 & 0,904 & 0,908 & 0,956 & 0,978 & 0,962 \\
\hline M1Ni & 0,000 & 0,000 & 0,000 & 0,000 & 0,000 & 0,000 & 0,000 & 0,000 & 0,000 & 0,000 & 0,000 \\
\hline M2Mg & 0,856 & 0,868 & 0,898 & 0,875 & 0,867 & 0,863 & 0,883 & 0,883 & 0,817 & 0,800 & 0,799 \\
\hline M2Fe2 & 0,115 & 0,107 & 0,084 & 0,104 & 0,109 & 0,113 & 0,098 & 0,095 & 0,140 & 0,164 & 0,157 \\
\hline M2Mn & 0,004 & 0,004 & 0,003 & 0,003 & 0,004 & 0,004 & 0,005 & 0,004 & 0,005 & 0,003 & 0,006 \\
\hline $\mathrm{M} 2 \mathrm{Ca}$ & 0,016 & 0,018 & 0,012 & 0,016 & 0,018 & 0,019 & 0,014 & 0,018 & 0,030 & 0,027 & 0,027 \\
\hline $\mathrm{M} 2 \mathrm{Na}$ & 0,004 & 0,003 & 0,003 & 0,002 & 0,002 & 0,001 & 0,000 & 0,000 & 0,006 & 0,005 & 0,007 \\
\hline M2K & 0,005 & 0,000 & 0,000 & 0,000 & 0,000 & 0,000 & 0,000 & 0,000 & 0,000 & 0,000 & 0,004 \\
\hline Cátions & 3,995 & 4,000 & 4,000 & 4,000 & 4,000 & 4,000 & 4,000 & 4,000 & 4,000 & 4,000 & 3,996 \\
\hline
\end{tabular}

$n=$ núcleo, $b=$ borda, int= entre núcleo e borda. Fórmula estrutural calculada com base em 6 oxigênios e 4 cátions. 
Anexo 2: Análises químicas em ortopiroxênio (continuação).

\begin{tabular}{|c|c|c|c|c|c|c|c|c|c|c|c|}
\hline Amostra & KIxm1 & Klxm1 & KIxm1 & KIxm1 & KIxm1 & KIxm1 & Klxm1 & KIxm1 & KIxm2 & KIxm2 & KIxm2 \\
\hline Cristal & 1 & 1 & 2 & 2 & 3 & 3 & 4 & 4 & 1 & 1 & 2 \\
\hline Posição & $n$ & int & $\mathrm{n}$ & b & $\mathrm{n}$ & b & $n$ & b & $\mathrm{n}$ & b & $\underline{n}$ \\
\hline $\mathrm{Ca}$ & 0,823 & 0,940 & 0,654 & 0,832 & 0,943 & 0,970 & 0,724 & 0,935 & 1,550 & 1,389 & 1,401 \\
\hline Mg & 92,925 & 93,264 & 94,748 & 93,577 & 93,163 & 92,939 & 93,881 & 93,874 & 90,985 & 90,119 & 90,255 \\
\hline Fe2_Mn & 6,252 & 5,796 & 4,598 & 5,591 & 5,894 & 6,090 & 5,395 & 5,191 & 7,465 & 8,492 & 8,344 \\
\hline JD1 & 0,457 & 0,158 & 0,131 & 0,113 & 0,114 & 0,070 & 0,004 & 0,003 & 0,000 & 0,000 & 0,000 \\
\hline AE1 & 0,000 & 0,000 & 0,000 & 0,000 & 0,000 & 0,000 & 0,000 & 0,000 & 0,347 & 0,271 & 0,549 \\
\hline CFTS1 & 2,817 & 3,582 & 4,471 & 3,581 & 3,274 & 2,877 & 3,675 & 4,155 & 1,555 & 0,757 & 1,077 \\
\hline CTTS1 & 0,000 & 0,051 & 0,033 & 0,019 & 0,013 & 0,007 & 0,000 & 0,058 & 0,323 & 0,108 & 0,332 \\
\hline CATS1 & 0,853 & 0,739 & 0,202 & 0,474 & 0,973 & 1,226 & 1,155 & 0,428 & 0,000 & 0,000 & 0,000 \\
\hline WO1 & 0,000 & 0,000 & 0,000 & 0,000 & 0,000 & 0,000 & 0,000 & 0,000 & 0,000 & 0,523 & 0,000 \\
\hline EN1 & 90,025 & 90,069 & 90,916 & 90,569 & 90,133 & 90,093 & 90,217 & 90,538 & 90,614 & 90,024 & 90,005 \\
\hline FS1 & 5,847 & 5,403 & 4,247 & 5,244 & 5,493 & 5,727 & 4,949 & 4,819 & 7,161 & 8,317 & 8,037 \\
\hline Q & 1,905 & 1,904 & 1,898 & 1,912 & 1,907 & 1,912 & 1,899 & 1,904 & 1,944 & 1,969 & 1,945 \\
\hline J & 0,008 & 0,006 & 0,005 & 0,004 & 0,004 & 0,003 & 0,000 & 0,000 & 0,013 & 0,010 & 0,014 \\
\hline wo & 0,804 & 0,912 & 0,629 & 0,807 & 0,917 & 0,948 & 0,702 & 0,901 & 1,504 & 1,376 & 1,371 \\
\hline EN & 90,803 & 90,474 & 91,108 & 90,734 & 90,675 & 90,835 & 91,003 & 90,456 & 88,311 & 89,276 & 88,266 \\
\hline FS & 8,393 & 8,614 & 8,263 & 8,459 & 8,408 & 8,216 & 8,295 & 8,643 & 10,185 & 9,347 & 10,364 \\
\hline WEF & 99,586 & 99,675 & 99,727 & 99,767 & 99,765 & 99,855 & 100,000 & 99,993 & 99,348 & 99,499 & 99,305 \\
\hline JD & 0,152 & 0,075 & 0,022 & 0,038 & 0,068 & 0,053 & 0,000 & 0,001 & 0,000 & 0,000 & 0,000 \\
\hline $\mathrm{AE}$ & 0,262 & 0,250 & 0,251 & 0,195 & 0,167 & 0,092 & 0,000 & 0,006 & 0,652 & 0,501 & 0,695 \\
\hline 100Mg\# & 91,73 & 91,47 & 91,85 & 91,62 & 91,71 & 91,89 & 91,88 & 91,47 & 89,91 & 90,71 & 89,76 \\
\hline
\end{tabular}

$n=$ núcleo, $b=$ borda, int= entre núcleo e borda. Fórmula estrutural calculada com base em 6 oxigênios e 4 cátions. 
Anexo 3: Resultados de análises químicas (elementos maiores) em cristais de clinopiroxênio de xenólitos do manto de Ubatuba e Monte Carmelo.

\begin{tabular}{|c|c|c|c|c|c|c|c|c|c|c|c|c|c|c|c|}
\hline Amostra & Ln9h & Ln9h & Ln9h & Ln9h & Ln9h & Ln9h & Ln9h & Ln9h & Ln9xm2 & Ln9xm2 & Ln9xm3 & Ln9xm3 & Ln9xm3 & Ln9xm3 & Ln9xm3 \\
\hline Cristal & 1 & 1 & 2 & 2 & 3 & 3 & 4 & 4 & 1 & 1 & 1 & 2 & 2 & 3 & 3 \\
\hline Posição & $\mathrm{n}$ & b & $\mathrm{n}$ & b & $\mathrm{n}$ & b & $\mathrm{n}$ & b & $\mathrm{n}$ & b & b & $n$ & b & $\mathbf{n}$ & b \\
\hline $\mathrm{SiO}_{2}$ & 52,06 & 51,72 & 51,90 & 52,45 & 52,07 & 51,76 & 52,36 & 51,07 & 53,67 & 53,18 & 51,40 & 51,59 & 51,72 & 51,27 & 51,99 \\
\hline $\mathrm{TiO}_{2}$ & 0,60 & 0,68 & 0,70 & 0,64 & 0,55 & 0,66 & 0,61 & 0,59 & 0,04 & 0,16 & 0,82 & 0,60 & 0,59 & 0,61 & 0,72 \\
\hline $\mathrm{Al}_{2} \mathrm{O}_{3}$ & 7,48 & 7,46 & 7,57 & 6,72 & 6,90 & 6,60 & 6,32 & 7,23 & 1,49 & 1,75 & 5,76 & 7,36 & 6,68 & 6,90 & 6,20 \\
\hline $\mathrm{FeO}$ & 2,55 & 2,60 & 2,55 & 2,80 & 2,63 & 2,64 & 2,58 & 2,99 & 2,96 & 3,07 & 2,41 & 2,58 & 2,50 & 2,48 & 2,53 \\
\hline MnO & 0,10 & 0,10 & 0,08 & 0,04 & 0,13 & 0,08 & 0,06 & 0,05 & 0,08 & 0,13 & 0,11 & 0,05 & 0,07 & 0,10 & 0,10 \\
\hline MgO & 13,99 & 13,85 & 13,85 & 14,82 & 14,41 & 14,66 & 14,96 & 14,98 & 17,68 & 17,41 & 14,97 & 13,56 & 14,18 & 14,65 & 14,64 \\
\hline $\mathrm{CaO}$ & 19,74 & 20,36 & 19,59 & 19,92 & 20,03 & 20,35 & 20,56 & 20,46 & 22,10 & 22,31 & 22,58 & 21,76 & 21,86 & 20,91 & 21,42 \\
\hline $\mathrm{Na}_{2} \mathrm{O}$ & 2,29 & 2,17 & 2,07 & 2,06 & 2,06 & 1,82 & 1,83 & 1,23 & 0,58 & 0,59 & 1,28 & 1,86 & 1,67 & 1,64 & 1,58 \\
\hline $\mathrm{K}_{2} \mathrm{O}$ & 0,01 & 0,00 & 0,01 & 0,00 & 0,01 & 0,00 & 0,00 & 0,07 & 0,01 & 0,00 & 0,00 & 0,00 & 0,01 & 0,01 & 0,00 \\
\hline $\mathrm{Cr}_{2} \mathrm{O}_{3}$ & 1,40 & 0,82 & 0,86 & 0,70 & 0,81 & 0,73 & 0,74 & 0,55 & 0,41 & 0,53 & 0,61 & 0,70 & 0,54 & 0,60 & 0,49 \\
\hline Total & 100,21 & 99,75 & 99,18 & 100,15 & 99,61 & 99,30 & 100,02 & 99,22 & 99,01 & 99,12 & 99,92 & 100,05 & 99,82 & 99,17 & 99,67 \\
\hline TSi & 1,875 & 1,871 & 1,889 & 1,887 & 1,884 & 1,881 & 1,888 & 1,862 & 1,961 & 1,944 & 1,863 & 1,866 & 1,874 & 1,866 & 1,886 \\
\hline TAl & 0,125 & 0,129 & 0,111 & 0,113 & 0,116 & 0,119 & 0,112 & 0,138 & 0,039 & 0,056 & 0,137 & 0,134 & 0,126 & 0,134 & 0,114 \\
\hline TFe3 & 0,000 & 0,000 & 0,000 & 0,000 & 0,000 & 0,000 & 0,000 & 0,000 & 0,000 & 0,000 & 0,000 & 0,000 & 0,000 & 0,000 & 0,000 \\
\hline M1AI & 0,192 & 0,189 & 0,214 & 0,171 & 0,179 & 0,164 & 0,156 & 0,172 & 0,025 & 0,019 & 0,109 & 0,180 & 0,159 & 0,161 & 0,151 \\
\hline M1Ti & 0,016 & 0,018 & 0,019 & 0,017 & 0,015 & 0,018 & 0,017 & 0,016 & 0,001 & 0,004 & 0,022 & 0,016 & 0,016 & 0,017 & 0,020 \\
\hline M1Fe3 & 0,021 & 0,032 & 0,000 & 0,030 & 0,028 & 0,025 & 0,028 & 0,007 & 0,042 & 0,055 & 0,055 & 0,032 & 0,037 & 0,038 & 0,019 \\
\hline M1Fe2 & 0,000 & 0,000 & 0,000 & 0,000 & 0,000 & 0,000 & 0,000 & 0,000 & 0,000 & 0,000 & 0,000 & 0,022 & 0,007 & 0,000 & 0,004 \\
\hline $\mathrm{M} 1 \mathrm{Cr}$ & 0,040 & 0,023 & 0,025 & 0,020 & 0,023 & 0,021 & 0,021 & 0,016 & 0,012 & 0,015 & 0,017 & 0,020 & 0,015 & 0,017 & 0,014 \\
\hline M1Mg & 0,732 & 0,738 & 0,742 & 0,761 & 0,755 & 0,772 & 0,778 & 0,789 & 0,921 & 0,907 & 0,796 & 0,731 & 0,766 & 0,767 & 0,792 \\
\hline M1Ni & 0,000 & 0,000 & 0,000 & 0,000 & 0,000 & 0,000 & 0,000 & 0,000 & 0,000 & 0,000 & 0,000 & 0,000 & 0,000 & 0,000 & 0,000 \\
\hline M2Mg & 0,019 & 0,009 & 0,010 & 0,034 & 0,022 & 0,022 & 0,027 & 0,025 & 0,042 & 0,042 & 0,012 & 0,000 & 0,000 & 0,027 & 0,000 \\
\hline M2Fe2 & 0,056 & 0,047 & 0,078 & 0,054 & 0,051 & 0,055 & 0,049 & 0,084 & 0,049 & 0,039 & 0,018 & 0,025 & 0,032 & 0,038 & 0,053 \\
\hline M2Mn & 0,003 & 0,003 & 0,003 & 0,001 & 0,004 & 0,003 & 0,002 & 0,001 & 0,002 & 0,004 & 0,003 & 0,001 & 0,002 & 0,003 & 0,003 \\
\hline $\mathrm{M} 2 \mathrm{Ca}$ & 0,762 & 0,789 & 0,764 & 0,768 & 0,777 & 0,792 & 0,794 & 0,799 & 0,865 & 0,874 & 0,877 & 0,843 & 0,849 & 0,815 & 0,832 \\
\hline $\mathrm{M} 2 \mathrm{Na}$ & 0,160 & 0,152 & 0,146 & 0,143 & 0,145 & 0,128 & 0,128 & 0,087 & 0,041 & 0,042 & 0,090 & 0,131 & 0,117 & 0,116 & 0,111 \\
\hline M2K & 0,000 & 0,000 & 0,000 & 0,000 & 0,001 & 0,000 & 0,000 & 0,003 & 0,000 & 0,000 & 0,000 & 0,000 & 0,000 & 0,000 & 0,000 \\
\hline Cátions & 4,000 & 4,000 & 4,000 & 4,000 & 3,999 & 4,000 & 4,000 & 3,997 & 4,000 & 4,000 & 4,000 & 4,000 & 4,000 & 4,000 & 4,000 \\
\hline
\end{tabular}

$n=$ núcleo, $b=$ borda, int= entre núcleo e borda. Fórmula estrutural calculada com base em 6 oxigênios e 4 cátions. 
Anexo 3: Análises químicas em clinopiroxênio (continuação).

\begin{tabular}{|c|c|c|c|c|c|c|c|c|c|c|c|c|c|c|c|}
\hline Amostra & Ln9h & Ln9h & Ln9h & Ln9h & Ln9h & Ln9h & Ln9h & Ln9h & Ln9xm2 & Ln9xm2 & Ln9xm3 & Ln9xm3 & Ln9xm3 & Ln9xm3 & Ln9xm3 \\
\hline Cristal & 1 & 1 & 2 & 2 & 3 & 3 & 4 & 4 & 1 & 1 & 1 & 2 & 2 & 3 & 3 \\
\hline Posição & $n$ & b & $\mathbf{n}$ & b & $n$ & b & $\mathbf{n}$ & b & $\mathrm{n}$ & b & b & $\mathrm{n}$ & b & $n$ & b \\
\hline $\mathrm{Ca}$ & 48,455 & 49,761 & 47,877 & 47,445 & 48,262 & 48,190 & 48,153 & 47,043 & 46,026 & 46,849 & 51,373 & 51,976 & 51,255 & 49,388 & 49,414 \\
\hline $\mathbf{M g}$ & 47,781 & 47,100 & 47,101 & 49,134 & 48,287 & 48,311 & 48,745 & 47,914 & 51,250 & 50,849 & 47,391 & 45,063 & 46,264 & 48,129 & 46,991 \\
\hline $\mathrm{Fe} 2 \_\mathrm{Mn}$ & 3,764 & 3,139 & 5,023 & 3,420 & 3,451 & 3,499 & 3,102 & 5,043 & 2,724 & 2,303 & 1,236 & 2,961 & 2,481 & 2,483 & 3,595 \\
\hline JD1 & 9,259 & 8,764 & 8,395 & 8,148 & 8,306 & 7,238 & 7,201 & 5,034 & 1,295 & 0,987 & 5,013 & 7,457 & 6,633 & 6,584 & 6,192 \\
\hline AE1 & 0,000 & 0,000 & 0,000 & 0,000 & 0,000 & 0,000 & 0,000 & 0,000 & 0,867 & 1,203 & 0,000 & 0,000 & 0,000 & 0,000 & 0,000 \\
\hline CFTS1 & 3,484 & 3,176 & 1,416 & 2,851 & 2,927 & 2,613 & 2,784 & 1,276 & 1,911 & 2,484 & 4,040 & 2,943 & 2,951 & 3,116 & 1,865 \\
\hline CTTS1 & 0,932 & 1,058 & 1,107 & 0,981 & 0,861 & 1,026 & 0,936 & 0,902 & 0,057 & 0,231 & 1,247 & 0,929 & 0,905 & 0,951 & 1,102 \\
\hline CATS1 & 1,840 & 2,103 & 3,907 & 1,582 & 1,894 & 2,002 & 1,608 & 4,597 & 0,000 & 0,000 & 1,060 & 2,796 & 2,329 & 2,552 & 2,237 \\
\hline W01 & 37,795 & 39,147 & 37,497 & 38,200 & 38,683 & 39,131 & 39,405 & 37,936 & 43,118 & 43,204 & 42,544 & 41,475 & 41,732 & 39,608 & 41,235 \\
\hline EN1 & 43,439 & 43,053 & 43,215 & 45,167 & 44,388 & 44,884 & 45,283 & 45,540 & 50,205 & 49,840 & 45,101 & 41,741 & 43,251 & 45,048 & 44,162 \\
\hline FS1 & 3,251 & 2,698 & 4,463 & 3,071 & 2,941 & 3,106 & 2,782 & 4,714 & 2,546 & 2,050 & 0,995 & 2,659 & 2,200 & 2,142 & 3,207 \\
\hline $\mathbf{Q}$ & 1,569 & 1,583 & 1,594 & 1,617 & 1,606 & 1,641 & 1,648 & 1,697 & 1,877 & 1,861 & 1,703 & 1,621 & 1,653 & 1,648 & 1,682 \\
\hline J & 0,319 & 0,304 & 0,292 & 0,287 & 0,290 & 0,256 & 0,256 & 0,173 & 0,082 & 0,083 & 0,180 & 0,261 & 0,234 & 0,231 & 0,222 \\
\hline wo & 47,829 & 48,785 & 47,877 & 46,575 & 47,437 & 47,464 & 47,341 & 46,850 & 45,030 & 45,509 & 49,767 & 50,982 & 50,141 & 48,287 & 48,853 \\
\hline EN & 47,164 & 46,176 & 47,101 & 48,233 & 47,462 & 47,582 & 47,923 & 47,717 & 50,142 & 49,395 & 45,909 & 44,202 & 45,259 & 47,056 & 46,457 \\
\hline FS & 5,007 & 5,040 & 5,023 & 5,192 & 5,101 & 4,954 & 4,737 & 5,434 & 4,828 & 5,096 & 4,325 & 4,816 & 4,600 & 4,657 & 4,690 \\
\hline WEF & 83,118 & 83,910 & 84,555 & 84,942 & 84,748 & 86,536 & 86,577 & 90,750 & 95,804 & 95,722 & 90,469 & 86,131 & 87,608 & 87,706 & 88,369 \\
\hline JD & 15,248 & 13,771 & 15,445 & 12,798 & 13,186 & 11,667 & 11,366 & 8,888 & 1,571 & 1,090 & 6,329 & 11,793 & 10,061 & 9,965 & 10,310 \\
\hline $\mathrm{AE}$ & 1,634 & 2,319 & 0,000 & 2,260 & 2,066 & 1,797 & 2,057 & 0,362 & 2,626 & 3,187 & 3,202 & 2,076 & 2,331 & 2,329 & 1,321 \\
\hline $100 * \mathrm{Mg} \#$ & 90,70 & 90,44 & 90,60 & 90,44 & 90,77 & 90,85 & 91,27 & 89,95 & 91,37 & 90,99 & 91,71 & 90,25 & 90,97 & 91,26 & 91,24 \\
\hline
\end{tabular}


Anexo 3: Análises químicas em clinopiroxênio (continuação).

\begin{tabular}{|c|c|c|c|c|c|c|c|c|c|c|c|c|c|c|c|}
\hline Amostra & Ln9xm3 & Ln9xm3 & Ln9xm3 & Ln9xm3 & Ln9xm3 & Ln9xm3 & Ln9xm3 & Ln9xm3 & Ln9xm1 & Ln9xm1 & Ln9g & Ln9xm2 & Lamprófiro & KIxm1 & KIxm1 \\
\hline Cristal & 4 & 5 & 5 & 6 & 6 & 7 & 7 & 8 & 1 & 2 & reação & reação & & 1 & 1 \\
\hline Posição & $\mathrm{n}$ & $\mathrm{n}$ & b & $\mathrm{n}$ & b & $\mathrm{n}$ & b & $\mathrm{n}$ & b & int & & & & $\mathrm{n}$ & int \\
\hline $\mathrm{SiO}_{2}$ & 51,15 & 51,32 & 52,95 & 51,07 & 50,91 & 51,25 & 48,15 & 50,92 & 52,53 & 52,09 & 51,86 & 53,06 & 40,11 & 52,89 & 52,98 \\
\hline $\mathrm{TiO}_{2}$ & 0,65 & 0,55 & 0,71 & 0,76 & 0,69 & 0,57 & 1,52 & 0,51 & 0,29 & 0,22 & 0,40 & 0,29 & 5,54 & 0,00 & 0,00 \\
\hline $\mathrm{Al}_{2} \mathrm{O}_{3}$ & 7,07 & 6,84 & 6,04 & 7,51 & 7,58 & 7,39 & 6,89 & 7,57 & 4,08 & 4,39 & 1,76 & 3,05 & 9,91 & 3,45 & 3,73 \\
\hline $\mathrm{FeO}$ & 2,99 & 2,42 & 2,47 & 2,68 & 2,51 & 2,50 & 4,69 & 2,53 & 2,58 & 2,49 & 4,18 & 2,13 & 8,14 & 1,60 & 1,54 \\
\hline MnO & 0,11 & 0,09 & 0,13 & 0,07 & 0,09 & 0,08 & 0,09 & 0,05 & 0,07 & 0,04 & 0,16 & 0,04 & 0,09 & 0,11 & 0,08 \\
\hline MgO & 15,67 & 13,99 & 14,52 & 13,98 & 13,56 & 13,75 & 13,12 & 13,90 & 15,58 & 15,39 & 19,15 & 16,43 & 10,80 & 16,14 & 16,08 \\
\hline $\mathrm{CaO}$ & 19,24 & 21,78 & 22,36 & 21,08 & 21,34 & 21,47 & 22,80 & 21,54 & 22,17 & 22,05 & 16,72 & 22,97 & 23,43 & 22,47 & 22,28 \\
\hline $\mathrm{Na}_{2} \mathrm{O}$ & 1,60 & 1,77 & 1,52 & 1,83 & 1,87 & 1,84 & 0,97 & 1,82 & 1,13 & 1,23 & 1,12 & 0,62 & 0,45 & 1,22 & 1,15 \\
\hline $\mathrm{K}_{2} \mathrm{O}$ & 0,01 & 0,01 & 0,00 & 0,00 & 0,01 & 0,00 & 0,08 & 0,01 & 0,01 & 0,01 & 0,12 & 0,02 & 0,01 & 0,00 & 0,01 \\
\hline $\mathrm{Cr}_{2} \mathrm{O}_{3}$ & 0,71 & 0,57 & 0,60 & 0,64 & 0,74 & 0,72 & 0,71 & 0,63 & 0,91 & 0,79 & 1,57 & 1,74 & 0,07 & 1,09 & 1,06 \\
\hline Total & 99,20 & 99,33 & 101,29 & 99,62 & 99,29 & 99,55 & 99,02 & 99,48 & 99,35 & 98,68 & 97,04 & 100,33 & 98,56 & 98,96 & 98,91 \\
\hline TSi & 1,856 & 1,867 & 1,895 & 1,853 & 1,854 & 1,861 & 1,784 & 1,848 & 1,916 & 1,910 & 1,923 & 1,923 & 1,528 & 1,928 & 1,933 \\
\hline TAI & 0,144 & 0,133 & 0,105 & 0,147 & 0,146 & 0,139 & 0,216 & 0,152 & 0,084 & 0,090 & 0,077 & 0,077 & 0,445 & 0,072 & 0,067 \\
\hline TFe3 & 0,000 & 0,000 & 0,000 & 0,000 & 0,000 & 0,000 & 0,000 & 0,000 & 0,000 & 0,000 & 0 & 0 & 0,027 & 0,000 & 0,000 \\
\hline M1AI & 0,159 & 0,160 & 0,149 & 0,173 & 0,179 & 0,177 & 0,085 & 0,172 & 0,091 & 0,099 & 0 & 0,053 & 0 & 0,076 & 0,093 \\
\hline M1Ti & 0,018 & 0,015 & 0,019 & 0,021 & 0,019 & 0,016 & 0,042 & 0,014 & 0,008 & 0,006 & 0,011 & 0,008 & 0,159 & 0,000 & 0,000 \\
\hline M1Fe3 & 0,041 & 0,051 & 0,006 & 0,042 & 0,038 & 0,040 & 0,098 & 0,061 & 0,030 & 0,044 & 0,095 & 0,003 & 0,185 & 0,000 & 0,025 \\
\hline M1Fe2 & 0,000 & 0,000 & 0,035 & 0,000 & 0,006 & 0,004 & 0,029 & 0,000 & 0,000 & 0,000 & 0 & 0 & 0,041 & 0,016 & 0,000 \\
\hline $\mathrm{M} 1 \mathrm{Cr}$ & 0,020 & 0,016 & 0,017 & 0,018 & 0,021 & 0,021 & 0,021 & 0,018 & 0,026 & 0,023 & 0,046 & 0,05 & 0,002 & 0,031 & 0,030 \\
\hline M1Mg & 0,762 & 0,758 & 0,775 & 0,745 & 0,736 & 0,744 & 0,725 & 0,735 & 0,844 & 0,829 & 0,848 & 0,887 & 0,613 & 0,877 & 0,852 \\
\hline M1Ni & 0,000 & 0,000 & 0,000 & 0,000 & 0,000 & 0,000 & 0,000 & 0,000 & 0,000 & 0,000 & 0 & 0 & 0 & 0,000 & 0,000 \\
\hline M2Mg & 0,086 & 0,001 & 0,000 & 0,011 & 0,000 & 0,000 & 0,000 & 0,017 & 0,003 & 0,013 & 0,21 & 0,001 & 0 & 0,000 & 0,023 \\
\hline M2Fe2 & 0,049 & 0,022 & 0,034 & 0,039 & 0,032 & 0,033 & 0,018 & 0,016 & 0,048 & 0,033 & 0,034 & 0,062 & 0,007 & 0,033 & 0,022 \\
\hline M2Mn & 0,003 & 0,003 & 0,004 & 0,002 & 0,003 & 0,002 & 0,003 & 0,002 & 0,002 & 0,001 & 0,005 & 0,001 & 0,003 & 0,003 & 0,002 \\
\hline $\mathrm{M} 2 \mathrm{Ca}$ & 0,748 & 0,849 & 0,857 & 0,819 & 0,833 & 0,835 & 0,905 & 0,838 & 0,866 & 0,866 & 0,664 & 0,892 & 0,957 & 0,877 & 0,871 \\
\hline $\mathrm{M} 2 \mathrm{Na}$ & 0,113 & 0,125 & 0,105 & 0,129 & 0,132 & 0,130 & 0,070 & 0,128 & 0,080 & 0,087 & 0,081 & 0,044 & 0,033 & 0,086 & 0,081 \\
\hline M2K & 0,000 & 0,000 & 0,000 & 0,000 & 0,000 & 0,000 & 0,004 & 0,000 & 0,001 & 0,000 & 0,005 & 0,001 & 0,001 & 0,000 & 0,000 \\
\hline Cátions & 4,000 & 4,000 & 4,000 & 4,000 & 4,000 & 4,000 & 3,996 & 4,000 & 3,999 & 4,000 & 3,995 & 3,999 & 3,999 & 4,000 & 4,000 \\
\hline
\end{tabular}

$n=$ núcleo, $b=$ borda, int= entre núcleo e borda. Fórmula estrutural calculada com base em 6 oxigênios e 4 cátions. 
Anexo 3: Análises químicas em clinopiroxênio (continuação).

\begin{tabular}{|c|c|c|c|c|c|c|c|c|c|c|c|c|c|c|c|}
\hline Amostra & Ln9xm3 & Ln9xm3 & Ln9xm3 & Ln9xm3 & Ln9xm3 & Ln9xm3 & Ln9xm3 & Ln9xm3 & Ln9xm1 & Ln9xm1 & Ln9g & Ln9xm2 & Lamprófiro & KIxm1 & KIxm1 \\
\hline Cristal & 4 & 5 & 5 & 6 & 6 & 7 & 7 & 8 & 1 & 2 & reação & reação & & 1 & 1 \\
\hline Posição & $\mathbf{n}$ & $\mathrm{n}$ & b & $\mathrm{n}$ & b & $\mathrm{n}$ & b & $\mathrm{n}$ & b & int & & & & $\mathrm{n}$ & int \\
\hline $\mathrm{Ca}$ & 45,380 & 51,987 & 50,303 & 50,677 & 51,731 & 51,637 & 53,874 & 52,127 & 49,117 & 49,730 & 37,691 & 48,419 & 59,02 & 48,574 & 49,208 \\
\hline $\mathrm{Mg}$ & 51,418 & 46,472 & 45,455 & 46,773 & 45,746 & 45,988 & 43,128 & 46,792 & 48,019 & 48,312 & 60,073 & 48,183 & 37,85 & 48,538 & 49,420 \\
\hline $\mathrm{Fe} 2 \_\mathrm{Mn}$ & 3,202 & 1,541 & 4,242 & 2,550 & 2,522 & 2,375 & 2,998 & 1,081 & 2,864 & 1,958 & 2,236 & 3,398 & 3,131 & 2,888 & 1,372 \\
\hline JD1 & 6,439 & 7,119 & 5,834 & 7,392 & 7,598 & 7,431 & 4,204 & 7,394 & 4,360 & 4,787 & 0 & 2,373 & 0 & 4,026 & 4,420 \\
\hline AE1 & 0,000 & 0,000 & 0,000 & 0,000 & 0,000 & 0,000 & 0,000 & 0,000 & 0,000 & 0,000 & 4,682 & 0 & 2,047 & 0,530 & 0,000 \\
\hline CFTS1 & 3,507 & 3,852 & 1,248 & 3,472 & 3,435 & 3,451 & 6,782 & 4,555 & 3,064 & 3,630 & 2,952 & 2,788 & 9,259 & 1,135 & 3,008 \\
\hline CTTS1 & 1,012 & 0,854 & 1,053 & 1,186 & 1,084 & 0,889 & 2,421 & 0,808 & 0,433 & 0,326 & 0,61 & 0,413 & 9,608 & 0,000 & 0,000 \\
\hline CATS1 & 2,582 & 1,982 & 2,432 & 2,553 & 2,710 & 2,694 & 0,640 & 2,521 & 0,596 & 0,634 & 0 & 0,442 & 0 & 0,000 & 0,602 \\
\hline WO1 & 35,444 & 41,681 & 42,744 & 39,780 & 40,651 & 40,834 & 41,853 & 40,439 & 42,940 & 42,793 & 32,466 & 43,653 & 39,048 & 45,312 & 43,487 \\
\hline EN1 & 48,206 & 43,239 & 42,902 & 43,372 & 42,340 & 42,631 & 41,385 & 43,377 & 45,982 & 46,031 & 57,421 & 47,067 & 37,141 & 46,412 & 47,299 \\
\hline FS1 & 2,810 & 1,272 & 3,787 & 2,245 & 2,182 & 2,070 & 2,715 & 0,906 & 2,625 & 1,799 & 1,87 & 3,262 & 2,898 & 2,585 & 1,185 \\
\hline Q & 1,645 & 1,630 & 1,700 & 1,614 & 1,607 & 1,616 & 1,678 & 1,605 & 1,762 & 1,740 & 1,757 & 1,841 & 1,618 & 1,803 & 1,767 \\
\hline $\mathbf{J}$ & 0,226 & 0,249 & 0,211 & 0,258 & 0,264 & 0,259 & 0,139 & 0,256 & 0,159 & 0,174 & 0,162 & 0,088 & 0,066 & 0,172 & 0,163 \\
\hline wo & 44,267 & 50,406 & 50,140 & 49,391 & 50,523 & 50,401 & 50,908 & 50,222 & 48,288 & 48,517 & 35,758 & 48,343 & 52,205 & 48,574 & 48,519 \\
\hline EN & 50,157 & 45,059 & 45,309 & 45,587 & 44,678 & 44,887 & 40,754 & 45,082 & 47,208 & 47,133 & 56,992 & 48,108 & 33,479 & 48,538 & 48,728 \\
\hline FS & 5,575 & 4,534 & 4,551 & 5,022 & 4,799 & 4,712 & 8,338 & 4,696 & 4,505 & 4,350 & 7,25 & 3,549 & 14,316 & 2,888 & 2,753 \\
\hline WEF & 87,962 & 86,749 & 88,997 & 86,250 & 85,919 & 86,183 & 92,340 & 86,277 & 91,712 & 90,901 & 91,598 & 95,462 & 96,068 & 91,318 & 91,575 \\
\hline JD & 9,545 & 10,034 & 10,610 & 11,064 & 11,592 & 11,284 & 3,556 & 10,130 & 6,222 & 6,321 & 0 & 4,304 & 0 & 8,682 & 6,631 \\
\hline $\mathrm{AE}$ & 2,493 & 3,217 & 0,393 & 2,686 & 2,489 & 2,533 & 4,104 & 3,593 & 2,066 & 2,779 & 8,402 & 0,234 & 3,932 & 0,000 & 1,795 \\
\hline $100 * \mathrm{Mg} \#$ & 90,41 & 91,23 & 91,18 & 90,32 & 90,64 & 90,62 & 83,33 & 90,71 & 91,57 & 91,62 & 89,13 & 93,18 & 70,22 & 94,71 & 97,55 \\
\hline
\end{tabular}


Anexo 3: Análises químicas em clinopiroxênio (continuação).

\begin{tabular}{|c|c|c|c|c|c|c|c|c|c|c|c|c|c|c|c|}
\hline Amostra & KIxm1 & KIxm1 & KIxm1 & KIxm2 & KIxm2 & KIxm2 & KIxm2 & Klxm2 & KIxm2 & KIxm2 & KIxm2 & $\mathrm{KIxm2}$ & KIxm3 & KIxm3 & KIxm3 \\
\hline Cristal & 2 & 2 & 3 & 1 & 1 & 2 & 3 & 3 & 4 & 4 & 5 & 5 & 1 & 1 & 2 \\
\hline Posição & $n$ & int & $\mathrm{n}$ & $\mathrm{n}$ & b & $\mathrm{n}$ & int & b & $\mathrm{n}$ & b & $\mathrm{n}$ & b & b & b & $\mathrm{n}$ \\
\hline $\mathrm{SiO}_{2}$ & 53,46 & 53,46 & 52,75 & 53,36 & 54,63 & 54,46 & 54,06 & 53,95 & 53,51 & 54,01 & 54,85 & 54,54 & 54,07 & 53,80 & 53,69 \\
\hline $\mathrm{TiO}_{2}$ & 0,06 & 0,09 & 0,02 & 0,46 & 0,40 & 0,42 & 0,32 & 0,32 & 0,43 & 0,28 & 0,34 & 0,36 & 0,14 & 0,54 & 0,78 \\
\hline $\mathrm{Al}_{2} \mathrm{O}_{3}$ & 3,32 & 3,37 & 3,34 & 0,92 & 0,76 & 0,81 & 0,85 & 0,79 & 0,86 & 0,82 & 0,79 & 0,81 & 0,52 & 0,24 & 0,04 \\
\hline $\mathrm{FeO}$ & 1,77 & 1,75 & 1,57 & 3,61 & 3,52 & 3,42 & 3,58 & 3,50 & 3,46 & 3,37 & 3,53 & 3,56 & 6,17 & 4,80 & 2,70 \\
\hline MnO & 0,09 & 0,07 & 0,08 & 0,16 & 0,08 & 0,11 & 0,11 & 0,11 & 0,08 & 0,09 & 0,10 & 0,13 & 0,09 & 0,13 & 0,02 \\
\hline MgO & 16,49 & 16,45 & 16,35 & 17,47 & 17,67 & 17,65 & 17,85 & 17,63 & 17,30 & 17,49 & 17,83 & 17,86 & 15,02 & 16,16 & 16,55 \\
\hline $\mathrm{CaO}$ & 22,18 & 22,43 & 22,49 & 19,76 & 20,03 & 19,76 & 20,14 & 20,20 & 19,62 & 19,81 & 19,98 & 20,13 & 21,40 & 22,20 & 24,71 \\
\hline $\mathrm{Na}_{2} \mathrm{O}$ & 1,02 & 1,07 & 1,09 & 1,32 & 1,12 & 1,25 & 1,10 & 1,18 & 1,31 & 1,24 & 1,02 & 1,11 & 1,55 & 0,88 & 0,63 \\
\hline $\mathrm{K}_{2} \mathrm{O}$ & 0,02 & 0,00 & 0,00 & 0,04 & 0,01 & 0,00 & 0,01 & 0,06 & 0,05 & 0,03 & 0,03 & 0,04 & 0,01 & 0,20 & 0,09 \\
\hline $\mathrm{Cr}_{2} \mathrm{O}_{3}$ & 1,08 & 1,04 & 1,04 & 1,70 & 1,54 & 1,52 & 1,15 & 1,28 & 1,87 & 1,63 & 1,32 & 1,21 & 0,30 & 0,34 & 0,12 \\
\hline Total & 99,49 & 99,72 & 98,72 & 98,80 & 99,75 & 99,40 & 99,18 & 99,01 & 98,48 & 98,76 & 99,77 & 99,75 & 99,26 & 99,30 & 99,34 \\
\hline TSi & 1,941 & 1,936 & 1,927 & 1,956 & 1,986 & 1,984 & 1,972 & 1,972 & 1,969 & 1,980 & 1,993 & 1,979 & 1,992 & 1,979 & 1,967 \\
\hline TAl & 0,059 & 0,064 & 0,073 & 0,040 & 0,014 & 0,016 & 0,028 & 0,028 & 0,031 & 0,020 & 0,007 & 0,021 & 0,008 & 0,011 & 0,002 \\
\hline TFe3 & 0,000 & 0,000 & 0,000 & 0,004 & 0,000 & 0,000 & 0,000 & 0,000 & 0,000 & 0,000 & 0,000 & 0,000 & 0,000 & 0,010 & 0,031 \\
\hline M1AI & 0,083 & 0,079 & 0,071 & 0,000 & 0,018 & 0,019 & 0,009 & 0,006 & 0,006 & 0,016 & 0,026 & 0,014 & 0,014 & 0,000 & 0,000 \\
\hline M1Ti & 0,002 & 0,002 & 0,001 & 0,013 & 0,011 & 0,011 & 0,009 & 0,009 & 0,012 & 0,008 & 0,009 & 0,010 & 0,004 & 0,015 & 0,022 \\
\hline M1Fe3 & 0,014 & 0,025 & 0,047 & 0,065 & 0,009 & 0,018 & 0,047 & 0,054 & 0,042 & 0,030 & 0,000 & 0,032 & 0,089 & 0,053 & 0,036 \\
\hline M1Fe2 & 0,000 & 0,000 & 0,000 & 0,000 & 0,000 & 0,000 & 0,000 & 0,000 & 0,000 & 0,000 & 0,000 & 0,000 & 0,060 & 0,036 & 0,015 \\
\hline $\mathrm{M} 1 \mathrm{Cr}$ & 0,031 & 0,030 & 0,030 & 0,049 & 0,044 & 0,044 & 0,033 & 0,037 & 0,054 & 0,047 & 0,038 & 0,035 & 0,009 & 0,010 & 0,004 \\
\hline M1Mg & 0,870 & 0,863 & 0,852 & 0,873 & 0,918 & 0,907 & 0,903 & 0,895 & 0,886 & 0,899 & 0,927 & 0,909 & 0,825 & 0,886 & 0,904 \\
\hline M1Ni & 0,000 & 0,000 & 0,000 & 0,000 & 0,000 & 0,000 & 0,000 & 0,000 & 0,000 & 0,000 & 0,000 & 0,000 & 0,000 & 0,000 & 0,000 \\
\hline M2Mg & 0,022 & 0,025 & 0,039 & 0,082 & 0,040 & 0,051 & 0,068 & 0,066 & 0,064 & 0,057 & 0,039 & 0,057 & 0,000 & 0,000 & 0,000 \\
\hline M2Fe2 & 0,040 & 0,028 & 0,001 & 0,041 & 0,098 & 0,086 & 0,063 & 0,053 & 0,065 & 0,073 & 0,107 & 0,076 & 0,041 & 0,049 & 0,000 \\
\hline M2Mn & 0,003 & 0,002 & 0,003 & 0,005 & 0,002 & 0,003 & 0,003 & 0,003 & 0,003 & 0,003 & 0,003 & 0,004 & 0,003 & 0,004 & 0,001 \\
\hline $\mathrm{M} 2 \mathrm{Ca}$ & 0,863 & 0,870 & 0,880 & 0,776 & 0,780 & 0,771 & 0,787 & 0,791 & 0,774 & 0,778 & 0,778 & 0,783 & 0,845 & 0,875 & 0,970 \\
\hline $\mathrm{M} 2 \mathrm{Na}$ & 0,072 & 0,075 & 0,077 & 0,094 & 0,079 & 0,088 & 0,078 & 0,084 & 0,093 & 0,088 & 0,072 & 0,078 & 0,111 & 0,063 & 0,045 \\
\hline M2K & 0,001 & 0,000 & 0,000 & 0,002 & 0,000 & 0,000 & 0,001 & 0,003 & 0,002 & 0,001 & 0,001 & 0,002 & 0,000 & 0,009 & 0,004 \\
\hline Cátions & 3,999 & 4,000 & 4,000 & 3,998 & 4,000 & 4,000 & 3,999 & 3,997 & 3,998 & 3,999 & 3,999 & 3,998 & 4,000 & 3,991 & 3,996 \\
\hline
\end{tabular}

$n=$ núcleo, $b=$ borda, int= entre núcleo e borda. Fórmula estrutural calculada com base em 6 oxigênios e 4 cátions. 
Anexo 3: Análises químicas em clinopiroxênio (continuação).

\begin{tabular}{|c|c|c|c|c|c|c|c|c|c|c|c|c|c|c|c|}
\hline Amostra & KIxm1 & KIxm1 & KIxm1 & KIxm2 & KIxm2 & KIxm2 & KIxm2 & KIxm2 & KIxm2 & Klxm2 & Klxm2 & KIxm2 & KIxm3 & KIxm3 & KIxm3 \\
\hline Cristal & 2 & 2 & 3 & 1 & 1 & 2 & 3 & 3 & 4 & 4 & 5 & 5 & 1 & 1 & 2 \\
\hline Posição & $n$ & int & $\mathrm{n}$ & $n$ & b & $\mathrm{n}$ & int & b & $\mathbf{n}$ & b & $\mathbf{n}$ & b & b & b & $\mathrm{n}$ \\
\hline $\mathrm{Ca}$ & 47,984 & 48,683 & 49,612 & 43,677 & 42,423 & 42,395 & 43,158 & 43,745 & 43,225 & 42,987 & 41,951 & 42,809 & 47,629 & 47,298 & 51,321 \\
\hline Mg & 49,648 & 49,659 & 50,180 & 53,739 & 52,086 & 52,700 & 53,226 & 53,133 & 53,025 & 52,826 & 52,108 & 52,831 & 46,514 & 47,919 & 47,827 \\
\hline Fe2_Mn & 2,368 & 1,658 & 0,209 & 2,584 & 5,490 & 4,906 & 3,617 & 3,123 & 3,750 & 4,187 & 5,941 & 4,360 & 5,858 & 4,783 & 0,852 \\
\hline JD1 & 3,893 & 4,052 & 3,841 & 0,000 & 0,959 & 0,998 & 0,449 & 0,307 & 0,342 & 0,833 & 1,373 & 0,745 & 0,750 & 0,000 & 0,000 \\
\hline AE1 & 0,000 & 0,000 & 0,320 & 5,135 & 3,172 & 3,640 & 3,679 & 4,258 & 4,736 & 3,874 & 2,430 & 3,462 & 5,154 & 3,770 & 2,543 \\
\hline CFTS1 & 2,403 & 2,958 & 3,837 & 0,992 & 0,000 & 0,000 & 0,519 & 0,550 & 0,371 & 0,209 & 0,000 & 0,050 & 0,032 & 0,000 & 0,000 \\
\hline CTTS1 & 0,088 & 0,124 & 0,030 & 0,676 & 0,570 & 0,603 & 0,468 & 0,464 & 0,625 & 0,407 & 0,377 & 0,510 & 0,206 & 0,551 & 0,089 \\
\hline CATS1 & 0,555 & 0,217 & 0,000 & 0,000 & 0,000 & 0,000 & 0,000 & 0,000 & 0,000 & 0,000 & 0,000 & 0,000 & 0,000 & 0,000 & 0,000 \\
\hline WO1 & 43,140 & 43,463 & 43,747 & 39,880 & 40,156 & 39,902 & 40,464 & 40,814 & 40,093 & 40,411 & 40,042 & 40,537 & 44,650 & 45,065 & 49,944 \\
\hline EN1 & 47,788 & 47,700 & 48,160 & 51,118 & 50,002 & 50,351 & 51,121 & 50,805 & 50,405 & 50,418 & 50,206 & 50,718 & 43,838 & 46,215 & 46,627 \\
\hline FS1 & 2,133 & 1,485 & 0,065 & 2,199 & 5,142 & 4,506 & 3,299 & 2,802 & 3,428 & 3,848 & 5,572 & 3,978 & 5,370 & 4,398 & 0,797 \\
\hline Q & 1,795 & 1,786 & 1,772 & 1,772 & 1,836 & 1,816 & 1,821 & 1,805 & 1,787 & 1,807 & 1,850 & 1,825 & 1,771 & 1,846 & 1,889 \\
\hline J & 0,143 & 0,151 & 0,154 & 0,188 & 0,157 & 0,176 & 0,156 & 0,167 & 0,187 & 0,176 & 0,144 & 0,157 & 0,222 & 0,126 & 0,090 \\
\hline wo & 47,612 & 48,007 & 48,335 & 42,030 & 42,227 & 41,971 & 42,084 & 42,473 & 42,237 & 42,280 & 41,951 & 42,065 & 45,352 & 45,732 & 49,557 \\
\hline EN & 49,264 & 48,968 & 48,888 & 51,712 & 51,845 & 52,173 & 51,901 & 51,589 & 51,814 & 51,958 & 52,108 & 51,913 & 44,291 & 46,332 & 46,183 \\
\hline FS & 3,124 & 3,025 & 2,777 & 6,259 & 5,928 & 5,856 & 6,015 & 5,938 & 5,950 & 5,762 & 5,941 & 6,022 & 10,357 & 7,936 & 4,260 \\
\hline WEF & 92,622 & 92,220 & 92,020 & 90,435 & 92,118 & 91,164 & 92,140 & 91,539 & 90,549 & 91,143 & 92,791 & 92,117 & 88,887 & 93,630 & 95,464 \\
\hline JD & 6,312 & 5,907 & 4,807 & 0,000 & 5,379 & 4,494 & 1,218 & 0,819 & 1,259 & 3,037 & 7,209 & 2,406 & 1,520 & 0,000 & 0,000 \\
\hline$A E$ & 1,066 & 1,873 & 3,172 & 9,565 & 2,503 & 4,342 & 6,642 & 7,642 & 8,191 & 5,820 & 0,000 & 5,477 & 9,593 & 6,370 & 4,536 \\
\hline $100 * \mathrm{Mg} \#$ & 95,71 & 96,94 & 99,89 & 95,88 & 90,72 & 91,76 & 93,91 & 94,77 & 93,60 & 92,91 & 90,03 & 92,71 & 89,09 & 91,25 & 98,37 \\
\hline
\end{tabular}

$n=$ núcleo, $b=$ borda, int= entre núcleo e borda. Fórmula estrutural calculada com base em 6 oxigênios e 4 cátions. 
Anexo 3: Análises químicas em clinopiroxênio (continuação).

\begin{tabular}{lrrrrrr}
\hline Amostra & KIxm3 & KIxm3 & KIxm3 & KIxm3 & KIxm3 & KIxm3 \\
\hline Cristal & $\mathbf{2}$ & $\mathbf{3}$ & $\mathbf{4}$ & $\mathbf{5}$ & $\mathbf{5}$ & $\mathbf{6}$ \\
\hline Posição & $\mathbf{b}$ & $\mathbf{n}$ & $\mathbf{b}$ & $\mathbf{n}$ & $\mathbf{b}$ & int \\
\hline SiO2 & 53,40 & 54,28 & 54,20 & 53,87 & 53,84 & 54,27 \\
TiO2 & 0,84 & 0,20 & 0,07 & 0,56 & 0,47 & 0,38 \\
Al2O3 & 0,20 & 0,63 & 0,56 & 0,09 & 0,09 & 0,04 \\
FeO & 3,77 & 6,17 & 6,47 & 2,49 & 2,43 & 2,75 \\
MnO & 0,09 & 0,10 & 0,14 & 0,04 & 0,00 & 0,04 \\
MgO & 16,47 & 15,59 & 14,78 & 16,48 & 16,62 & 16,55 \\
CaO & 23,39 & 20,77 & 21,01 & 24,95 & 25,20 & 25,03 \\
Na2O & 0,56 & 1,34 & 1,69 & 0,49 & 0,48 & 0,50 \\
K2O & 0,01 & 0,01 & 0,00 & 0,02 & 0,02 & 0,01 \\
Cr2O3 & 0,48 & 0,28 & 0,39 & 0,54 & 0,55 & 0,39 \\
Total & 99,22 & 99,35 & 99,33 & 99,52 & 99,70 & 99,96 \\
\hline TSi & 1,967 & 1,997 & 1,996 & 1,973 & 1,967 & 1,979 \\
TAI & 0,009 & 0,003 & 0,004 & 0,004 & 0,004 & 0,002 \\
TFe3 & 0,024 & 0,000 & 0,000 & 0,023 & 0,029 & 0,020 \\
M1AI & 0,000 & 0,024 & 0,021 & 0,000 & 0,000 & 0,000 \\
M1Ti & 0,023 & 0,006 & 0,002 & 0,015 & 0,013 & 0,011 \\
M1Fe3 & 0,012 & 0,055 & 0,088 & 0,016 & 0,026 & 0,025 \\
M1Fe2 & 0,046 & 0,052 & 0,066 & 0,037 & 0,019 & 0,039 \\
M1Cr & 0,014 & 0,008 & 0,011 & 0,016 & 0,016 & 0,011 \\
M1Mg & 0,904 & 0,855 & 0,812 & 0,900 & 0,905 & 0,899 \\
M1Ni & 0,000 & 0,000 & 0,000 & 0,000 & 0,000 & 0,000 \\
M2Mg & 0,000 & 0,000 & 0,000 & 0,000 & 0,000 & 0,000 \\
M2Fe2 & 0,034 & 0,082 & 0,045 & 0,000 & 0,000 & 0,000 \\
M2Mn & 0,003 & 0,003 & 0,004 & 0,001 & 0,000 & 0,001 \\
M2Ca & 0,923 & 0,819 & 0,829 & 0,979 & 0,986 & 0,978 \\
M2Na & 0,040 & 0,096 & 0,121 & 0,034 & 0,034 & 0,036 \\
M2K & 0,000 & 0,000 & 0,000 & 0,001 & 0,001 & 0,000 \\
Cátions & 4,000 & 4,000 & 4,000 & 3,999 & 3,999 & 4,000 \\
\hline
\end{tabular}

\begin{tabular}{lrrrrrr}
\hline Amostra & KIxm3 & KIxm3 & Klxm3 & Klxm3 & KIxm3 & KIxm3 \\
\hline Cristal & $\mathbf{2}$ & $\mathbf{3}$ & $\mathbf{4}$ & $\mathbf{5}$ & $\mathbf{5}$ & $\mathbf{6}$ \\
\hline Posição & $\mathbf{b}$ & $\mathbf{n}$ & $\mathbf{b}$ & $\mathbf{n}$ & $\mathbf{b}$ & int \\
\hline Ca & 48,316 & 45,206 & 47,214 & 51,068 & 51,624 & 50,989 \\
Mg & 47,332 & 47,208 & 46,217 & 46,932 & 47,376 & 46,905 \\
Fe2_Mn & 4,352 & 7,586 & 6,569 & 2,000 & 1,001 & 2,107 \\
JD1 & 0,000 & 1,272 & 1,112 & 0,000 & 0,000 & 0,000 \\
AE1 & 2,052 & 3,763 & 5,355 & 1,815 & 1,779 & 1,840 \\
CFTS1 & 0,000 & 0,000 & 0,000 & 0,000 & 0,357 & 0,016 \\
CTTS1 & 0,450 & 0,157 & 0,109 & 0,197 & 0,199 & 0,086 \\
CATS1 & 0,000 & 0,000 & 0,000 & 0,000 & 0,000 & 0,000 \\
WO1 & 46,947 & 42,846 & 44,160 & 49,978 & 50,149 & 49,981 \\
EN1 & 46,432 & 44,907 & 43,334 & 46,112 & 46,533 & 46,072 \\
FS1 & 4,119 & 7,054 & 5,929 & 1,898 & 0,983 & 2,006 \\
Q & 1,908 & 1,808 & 1,752 & 1,916 & 1,911 & 1,916 \\
J & 0,079 & 0,191 & 0,242 & 0,069 & 0,068 & 0,071 \\
WO & 47,421 & 43,862 & 44,954 & 50,041 & 50,179 & 49,825 \\
EN & 46,456 & 45,804 & 44,005 & 45,989 & 46,050 & 45,834 \\
FS & 6,123 & 10,333 & 11,041 & 3,969 & 3,772 & 4,341 \\
WEF & 96,016 & 90,457 & 87,890 & 96,532 & 96,577 & 96,417 \\
JD & 0,000 & 2,900 & 2,311 & 0,000 & 0,000 & 0,000 \\
AE & 3,984 & 6,643 & 9,799 & 3,468 & 3,423 & 3,583 \\
100*Mg\# & 91,87 & 86,45 & 87,97 & 96,05 & 97,94 & 95,84 \\
\hline & & & & & &
\end{tabular}

$n=$ núcleo, $b=$ borda, int= entre núcleo e borda. Fórmula estrutural calculada com base em 6 oxigênios e 4 cátions. 
Anexo 4: Resultados de análises químicas (elementos maiores) em cristais de espinélio de xenólitos do manto de Ubatuba e Monte Carmelo.

\begin{tabular}{|c|c|c|c|c|c|c|c|c|c|c|c|c|c|c|c|}
\hline Amostra & Ln9h & Ln9h & Ln9h & Ln9h & Ln9h & Ln9xm3 & Ln9xm3 & $\operatorname{Ln} 9 \times \mathrm{xm} 3$ & Ln9xm3 & Ln9xm3 & Ln9xm1 & KIxm1 & KIxm1 & KIxm1 & KIxm1 \\
\hline Cristal & 1 & 1 & 2 & 3 & 3 & 1 & 2 & 3 & 4 & 4 & 1 & 1 & 1 & 2 & 2 \\
\hline Posição & $n$ & b & $n$ & $n$ & b & $n$ & int & b & $\mathrm{n}$ & b & b & $\mathrm{n}$ & b & $\mathbf{n}$ & b \\
\hline $\mathrm{TiO}_{2}$ & 0,13 & 0,12 & 0,08 & 0,00 & 0,11 & 0,06 & 0,10 & 0,15 & 0,08 & 0,05 & 0,10 & 0,00 & 0,00 & 0,01 & 0,00 \\
\hline $\mathrm{Al}_{2} \mathrm{O}_{3}$ & 58,00 & 57,96 & 57,70 & 57,52 & 57,91 & 58,75 & 57,71 & 57,95 & 59,37 & 60,62 & 49,56 & 39,98 & 41,00 & 38,90 & 39,74 \\
\hline $\mathrm{Cr}_{2} \mathrm{O}_{3}$ & 9,33 & 9,23 & 9,69 & 9,57 & 9,61 & 7,52 & 7,65 & 7,41 & 6,53 & 6,16 & 14,94 & 27,80 & 27,21 & 29,71 & 27,78 \\
\hline $\mathrm{FeO}$ & 10,57 & 10,76 & 10,96 & 10,11 & 10,85 & 9,95 & 8,93 & 9,57 & 9,85 & 10,81 & 9,49 & 13,88 & 13,63 & 14,37 & 12,37 \\
\hline $\mathrm{Fe}_{2} \mathrm{O}_{3}$ & 2,02 & 1,76 & 1,60 & 2,77 & 1,97 & 2,71 & 3,83 & 3,89 & 2,61 & 1,38 & 5,43 & 2,45 & 2,24 & 1,54 & 3,25 \\
\hline MnO & 0,09 & 0,14 & 0,09 & 0,09 & 0,08 & 0,08 & 0,06 & 0,11 & 0,10 & 0,05 & 0,14 & 0,14 & 0,09 & 0,10 & 0,12 \\
\hline MgO & 20,01 & 19,82 & 19,61 & 20,19 & 19,78 & 20,24 & 20,76 & 20,45 & 20,23 & 19,88 & 19,51 & 15,78 & 16,15 & 15,49 & 16,76 \\
\hline Zno & 0,22 & 0,14 & 0,18 & 0,19 & 0,20 & 0,25 & 0,14 & 0,24 & 0,23 & 0,18 & 0,13 & 0,32 & 0,24 & 0,18 & 0,21 \\
\hline Total & 100,38 & 99,93 & 99,91 & 100,44 & 100,51 & 99,56 & 99,18 & 99,76 & 98,99 & 99,14 & 99,32 & 100,35 & 100,56 & 100,29 & 100,22 \\
\hline FeOI & 12,390 & 12,343 & 12,397 & 12,604 & 12,618 & 12,388 & 12,374 & 13,068 & 12,194 & 12,056 & 14,375 & 16,084 & 15,649 & 15,760 & 15,292 \\
\hline Al & 1,763 & 1,769 & 1,764 & 1,749 & 1,760 & 1,789 & 1,763 & 1,765 & 1,811 & 1,842 & 1,568 & 1,327 & 1,350 & 1,299 & 1,314 \\
\hline $\mathrm{Ti}$ & 0,003 & 0,002 & 0,002 & 0,000 & 0,002 & 0,001 & 0,002 & 0,003 & 0,001 & 0,001 & 0,002 & 0,000 & 0,000 & 0,000 & 0,000 \\
\hline $\mathrm{Cr}$ & 0,190 & 0,189 & 0,199 & 0,195 & 0,196 & 0,154 & 0,157 & 0,151 & 0,134 & 0,126 & 0,317 & 0,619 & 0,601 & 0,665 & 0,616 \\
\hline $\mathrm{Fe} 2$ & 0,228 & 0,233 & 0,238 & 0,218 & 0,234 & 0,215 & 0,194 & 0,207 & 0,213 & 0,233 & 0,213 & 0,327 & 0,319 & 0,341 & 0,290 \\
\hline Fe3 & 0,039 & 0,034 & 0,031 & 0,054 & 0,038 & 0,053 & 0,075 & 0,076 & 0,051 & 0,027 & 0,110 & 0,052 & 0,047 & 0,033 & 0,069 \\
\hline Mn & 0,002 & 0,003 & 0,002 & 0,002 & 0,002 & 0,002 & 0,001 & 0,002 & 0,002 & 0,001 & 0,003 & 0,003 & 0,002 & 0,002 & 0,003 \\
\hline Mg & 0,770 & 0,766 & 0,759 & 0,777 & 0,761 & 0,780 & 0,803 & 0,789 & 0,781 & 0,765 & 0,781 & 0,663 & 0,673 & 0,655 & 0,701 \\
\hline Zn & 0,000 & 0,000 & 0,000 & 0,000 & 0,000 & 0,000 & 0,000 & 0,000 & 0,000 & 0,000 & 0,000 & 0,010 & 0,000 & 0,000 & 0,000 \\
\hline Cátions & 2,995 & 2,996 & 2,995 & 2,995 & 2,993 & 2,994 & 2,995 & 2,993 & 2,993 & 2,995 & 2,994 & 3,001 & 2,992 & 2,995 & 2,993 \\
\hline
\end{tabular}

$n=$ núcleo, $b=$ borda, int= entre núcleo e borda. Fórmula estrutural calculada com base em 4 oxigênios e 3 cátions. 
Anexo 4: Análises químicas em espinélio (continuação)..

\begin{tabular}{|c|c|c|c|c|c|c|c|c|c|c|c|c|c|c|c|}
\hline Amostra & Ln9h & Ln9h & Ln9h & Ln9h & Ln9h & Ln9xm3 & Ln9xm3 & Ln9xm3 & Ln9xm3 & Ln9xm3 & Ln9xm1 & KIxm1 & KIxm1 & KIxm1 & KIxm1 \\
\hline Cristal & 1 & 1 & 2 & 3 & 3 & 1 & 2 & 3 & 4 & 4 & 1 & 1 & 1 & 2 & 2 \\
\hline Posição & $\mathbf{n}$ & b & $\mathbf{n}$ & $\mathbf{n}$ & b & $\mathrm{n}$ & int & b & $\mathrm{n}$ & b & b & $\mathbf{n}$ & b & $\mathbf{n}$ & b \\
\hline Fe3_TRIVAL & 0,020 & 0,017 & 0,016 & 0,027 & 0,019 & 0,027 & 0,038 & 0,038 & 0,026 & 0,014 & 0,055 & 0,026 & 0,024 & 0,017 & 0,035 \\
\hline AI_TRIVAL & 0,885 & 0,888 & 0,885 & 0,875 & 0,883 & 0,896 & 0,884 & 0,886 & 0,907 & 0,923 & 0,786 & 0,664 & 0,676 & 0,650 & 0,657 \\
\hline Cr_TRIVAL & 0,095 & 0,095 & 0,100 & 0,098 & 0,098 & 0,077 & 0,079 & 0,076 & 0,067 & 0,063 & 0,159 & 0,310 & 0,301 & 0,333 & 0,308 \\
\hline $\mathrm{Cr} \#$ & 0,097 & 0,097 & 0,101 & 0,100 & 0,100 & 0,079 & 0,082 & 0,079 & 0,069 & 0,064 & 0,168 & 0,318 & 0,308 & 0,339 & 0,319 \\
\hline XFe & 0,228 & 0,233 & 0,239 & 0,219 & 0,235 & 0,216 & 0,195 & 0,208 & 0,214 & 0,233 & 0,214 & 0,330 & 0,322 & 0,342 & 0,293 \\
\hline XMg & 0,772 & 0,767 & 0,761 & 0,781 & 0,765 & 0,784 & 0,805 & 0,792 & 0,786 & 0,767 & 0,786 & 0,670 & 0,678 & 0,658 & 0,707 \\
\hline PMTiO2 & 0,002 & 0,002 & 0,001 & 0,000 & 0,001 & 0,001 & 0,001 & 0,002 & 0,001 & 0,001 & 0,001 & 0,000 & 0,000 & 0,000 & 0,000 \\
\hline PMAI2O3 & 0,569 & 0,569 & 0,566 & 0,564 & 0,568 & 0,576 & 0,566 & 0,568 & 0,582 & 0,595 & 0,486 & 0,392 & 0,402 & 0,382 & 0,390 \\
\hline PMCr2O3 & 0,061 & 0,061 & 0,064 & 0,063 & 0,063 & 0,049 & 0,050 & 0,049 & 0,043 & 0,041 & 0,098 & 0,183 & 0,179 & 0,195 & 0,183 \\
\hline PMFeOI & 0,172 & 0,172 & 0,173 & 0,175 & 0,176 & 0,172 & 0,172 & 0,182 & 0,170 & 0,168 & 0,200 & 0,224 & 0,218 & 0,219 & 0,213 \\
\hline PMFeO & 0,147 & 0,150 & 0,153 & 0,141 & 0,151 & 0,138 & 0,124 & 0,133 & 0,137 & 0,150 & 0,132 & 0,193 & 0,190 & 0,200 & 0,172 \\
\hline PMFe2O3 & 0,013 & 0,011 & 0,010 & 0,017 & 0,012 & 0,017 & 0,024 & 0,024 & 0,016 & 0,009 & 0,034 & 0,015 & 0,014 & 0,010 & 0,020 \\
\hline PMMnO & 0,001 & 0,002 & 0,001 & 0,001 & 0,001 & 0,001 & 0,001 & 0,002 & 0,001 & 0,001 & 0,002 & 0,002 & 0,001 & 0,001 & 0,002 \\
\hline PMMgO & 0,496 & 0,491 & 0,486 & 0,501 & 0,491 & 0,502 & 0,515 & 0,507 & 0,502 & 0,493 & 0,484 & 0,391 & 0,401 & 0,384 & 0,416 \\
\hline PMZnO & 0,003 & 0,002 & 0,002 & 0,002 & 0,002 & 0,003 & 0,002 & 0,003 & 0,003 & 0,002 & 0,002 & 0,004 & 0,003 & 0,002 & 0,003 \\
\hline SUM1 & 0,634 & 0,634 & 0,632 & 0,627 & 0,633 & 0,627 & 0,618 & 0,621 & 0,627 & 0,638 & 0,586 & 0,575 & 0,581 & 0,577 & 0,573 \\
\hline DIFFEO & 0,038 & 0,033 & 0,030 & 0,052 & 0,037 & 0,051 & 0,072 & 0,073 & 0,049 & 0,026 & 0,102 & 0,046 & 0,042 & 0,029 & 0,061 \\
\hline
\end{tabular}

$n=$ núcleo, $b=$ borda, int= entre núcleo e borda. Fórmula estrutural calculada com base em 4 oxigênios e 3 cátions. 
Anexo 4: Análises químicas em espinélio (continuação).

\begin{tabular}{|c|c|c|c|c|c|c|c|}
\hline Amostra & KIxm1 & KIxm1 & KIxm2 & Amostra & KIxm1 & KIxm1 & KIxm2 \\
\hline Cristal & 3 & 3 & 1 & Cristal & 3 & 3 & 1 \\
\hline Posição & $\mathbf{n}$ & b & $\underline{n}$ & Posição & $\mathrm{n}$ & b & $\mathrm{n}$ \\
\hline $\mathrm{TiO}_{2}$ & 0,00 & 0,00 & 4,74 & Fe3_TRIVAL & 0,015 & 0,017 & 0,159 \\
\hline $\mathrm{Al}_{2} \mathrm{O}_{3}$ & 38,91 & 39,01 & 3,51 & Al_TRIVAL & 0,654 & 0,653 & 0,080 \\
\hline $\mathrm{Cr}_{2} \mathrm{O}_{3}$ & 29,38 & 29,39 & 49,83 & Cr_TRIVAL & 0,331 & 0,330 & 0,761 \\
\hline $\mathrm{FeO}$ & 14,13 & 13,73 & 21,61 & $\mathrm{Cr} \#$ & 0,336 & 0,336 & 0,905 \\
\hline $\mathrm{Fe}_{2} \mathrm{O}_{3}$ & 1,33 & 1,60 & 10,91 & $\mathrm{XFe}$ & 0,340 & 0,329 & 0,553 \\
\hline MnO & 0,11 & 0,15 & 0,19 & $\mathrm{XMg}$ & 0,660 & 0,671 & 0,447 \\
\hline MgO & 15,40 & 15,74 & 9,81 & PMTiO2 & 0,000 & 0,000 & 0,059 \\
\hline Zno & 0,26 & 0,22 & 0,16 & PMAI2O3 & 0,382 & 0,383 & 0,034 \\
\hline Total & 99,52 & 99,83 & 100,76 & PMCr2O3 & 0,193 & 0,193 & 0,328 \\
\hline FeOI & 15,328 & 15,174 & 31,424 & PMFeOI & 0,213 & 0,211 & 0,437 \\
\hline Al & 1,307 & 1,305 & 0,140 & PMFeO & 0,197 & 0,191 & 0,301 \\
\hline Ti & 0,000 & 0,000 & 0,121 & PMFe2O3 & 0,008 & 0,010 & 0,068 \\
\hline $\mathrm{Cr}$ & 0,662 & 0,659 & 1,337 & PMMnO & 0,002 & 0,002 & 0,003 \\
\hline Fe2 & 0,337 & 0,326 & 0,614 & PMMgO & 0,382 & 0,390 & 0,243 \\
\hline $\mathrm{Fe} 3$ & 0,029 & 0,034 & 0,279 & PMZno & 0,003 & 0,003 & 0,002 \\
\hline Mn & 0,003 & 0,003 & 0,006 & SUM1 & 0,575 & 0,576 & 0,480 \\
\hline Mg & 0,655 & 0,666 & 0,497 & DIFFEO & 0,025 & 0,030 & 0,205 \\
\hline
\end{tabular}

Cátions $\quad 3,003 \quad 2,993 \quad 2,994$

$n=$ núcleo, $b=$ borda, int= entre núcleo e borda. Fórmula estrutural calculada com base em 4 oxigênios e 3 cátions. 
Anexo 5: Resultados de análises químicas (elementos maiores) em cristais de flogopita de xenólitos do manto de Monte Carmelo.

\begin{tabular}{|c|c|c|c|c|c|c|c|c|c|c|c|c|c|c|c|}
\hline Amostra & KIxm2 & KIxm2 & KIxm2 & KIxm2 & Klxm2 & Klxm2 & KIxm2 & $\mathrm{KIxm2}$ & KIxm3 & KIxm3 & Klxm3 & KIxm3 & KIxm3 & KIxm3 & KIxm3 \\
\hline Cristal & 1 & 1 & 2 & 2 & 3 & 4 & 5 & 5 & 1 & 1 & 1 & 2 & 2 & 2 & 3 \\
\hline Posição & $\mathrm{n}$ & b & $\mathbf{n}$ & int & $\mathbf{n}$ & $\mathrm{n}$ & $\mathrm{n}$ & b & $\mathrm{n}$ & int & b & b & int & b & $\mathrm{n}$ \\
\hline $\mathrm{SiO}_{2}$ & 40,89 & 40,56 & 40,59 & 40,19 & 41,27 & 40,45 & 41,22 & 41,00 & 41,14 & 41,39 & 38,79 & 39,62 & 41,11 & 41,43 & 40,64 \\
\hline $\mathrm{TiO}_{2}$ & 2,62 & 2,70 & 2,41 & 2,49 & 2,71 & 3,08 & 2,73 & 2,81 & 0,96 & 1,09 & 3,95 & 3,25 & 1,12 & 1,03 & 2,10 \\
\hline $\mathrm{Al}_{2} \mathrm{O}_{3}$ & 12,38 & 12,01 & 12,24 & 12,18 & 12,17 & 11,94 & 12,36 & 12,24 & 10,11 & 10,38 & 10,35 & 10,19 & 10,23 & 10,31 & 9,86 \\
\hline $\mathrm{FeO}$ & 4,60 & 5,04 & 4,65 & 4,69 & 4,68 & 4,47 & 4,81 & 4,51 & 7,50 & 7,39 & 9,92 & 9,80 & 7,59 & 7,74 & 7,02 \\
\hline MnO & 0,02 & 0,03 & 0,03 & 0,02 & 0,04 & 0,03 & 0,04 & 0,02 & 0,05 & 0,03 & 0,03 & 0,05 & 0,01 & 0,06 & 0,05 \\
\hline MgO & 23,02 & 23,63 & 22,90 & 23,34 & 23,10 & 23,53 & 23,27 & 22,80 & 22,37 & 22,60 & 19,72 & 20,58 & 22,87 & 22,65 & 22,79 \\
\hline $\mathrm{CaO}$ & 0,07 & 0,07 & 0,00 & 0,01 & 0,02 & 0,00 & 0,02 & 0,00 & 0,03 & 0,06 & 0,03 & 0,06 & 0,03 & 0,00 & 0,01 \\
\hline $\mathrm{Na}_{2} \mathrm{O}$ & 0,09 & 0,03 & 0,08 & 0,06 & 0,09 & 0,10 & 0,03 & 0,04 & 0,23 & 0,37 & 0,05 & 0,03 & 0,43 & 0,44 & 0,23 \\
\hline $\mathrm{K}_{2} \mathrm{O}$ & 10,27 & 10,37 & 10,63 & 10,81 & 10,61 & 10,85 & 10,71 & 10,67 & 10,44 & 10,24 & 10,12 & 10,16 & 10,01 & 10,44 & 10,49 \\
\hline$F$ & 0,67 & 0,58 & 0,24 & 0,73 & 0,61 & 0,55 & 0,35 & 0,58 & 0,38 & 0,36 & 0,39 & 0,57 & 0,29 & 0,78 & 0,23 \\
\hline $\mathrm{Cl}$ & 0,02 & 0,00 & 0,01 & 0,05 & 0,02 & 0,02 & 0,00 & 0,01 & 0,04 & 0,03 & 0,01 & 0,01 & 0,04 & 0,03 & 0,03 \\
\hline $\mathrm{BaO}$ & 0,07 & 0,13 & 0,08 & 0,04 & 0,01 & 0,01 & 0,03 & 0,05 & 0,21 & 0,21 & 0,24 & 0,16 & 0,07 & 0,25 & 0,30 \\
\hline Total & 94,69 & 95,14 & 93,85 & 94,60 & 95,32 & 95,03 & 95,57 & 94,73 & 93,45 & 94,15 & 93,59 & 94,48 & 93,80 & 95,16 & 93,75 \\
\hline Si & 5,898 & 5,846 & 5,898 & 5,841 & 5,919 & 5,835 & 5,887 & 5,914 & 6,105 & 6,083 & 5,838 & 5,901 & 6,057 & 6,072 & 6,008 \\
\hline AlIV & 2,102 & 2,038 & 2,095 & 2,085 & 2,056 & 2,029 & 2,080 & 2,080 & 1,767 & 1,797 & 1,835 & 1,788 & 1,776 & 1,779 & 1,717 \\
\hline AIVI & 0,001 & 0,000 & 0,000 & 0,000 & 0,000 & 0,000 & 0,000 & 0,000 & 0,000 & 0,000 & 0,000 & 0,000 & 0,000 & 0,000 & 0,000 \\
\hline Total & 8,000 & 7,884 & 7,993 & 7,926 & 7,975 & 7,864 & 7,967 & 7,994 & 7,872 & 7,880 & 7,673 & 7,689 & 7,833 & 7,851 & 7,725 \\
\hline Ti & 0,284 & 0,292 & 0,264 & 0,273 & 0,292 & 0,334 & 0,293 & 0,305 & 0,107 & 0,120 & 0,447 & 0,364 & 0,125 & 0,113 & 0,234 \\
\hline Fe2 & 0,555 & 0,608 & 0,565 & 0,570 & 0,561 & 0,539 & 0,574 & 0,544 & 0,931 & 0,908 & 1,249 & 1,221 & 0,935 & 0,949 & 0,868 \\
\hline Mn & 0,002 & 0,003 & 0,003 & 0,003 & 0,004 & 0,004 & 0,005 & 0,003 & 0,006 & 0,004 & 0,004 & 0,007 & 0,001 & 0,008 & 0,006 \\
\hline Mg & 4,949 & 5,077 & 4,961 & 5,056 & 4,939 & 5,060 & 4,954 & 4,903 & 4,948 & 4,951 & 4,425 & 4,570 & 5,024 & 4,948 & 5,023 \\
\hline $\mathrm{Ba}$ & 0,004 & 0,007 & 0,005 & 0,002 & 0,000 & 0,001 & 0,002 & 0,003 & 0,012 & 0,012 & 0,014 & 0,009 & 0,004 & 0,015 & 0,017 \\
\hline $\mathrm{Ca}$ & 0,010 & 0,011 & 0,000 & 0,002 & 0,002 & 0,000 & 0,003 & 0,000 & 0,004 & 0,010 & 0,004 & 0,009 & 0,005 & 0,000 & 0,002 \\
\hline $\mathrm{Na}$ & 0,024 & 0,009 & 0,023 & 0,016 & 0,024 & 0,028 & 0,007 & 0,011 & 0,065 & 0,105 & 0,014 & 0,010 & 0,123 & 0,124 & 0,065 \\
\hline K & 1,889 & 1,907 & 1,971 & 2,004 & 1,940 & 1,997 & 1,952 & 1,964 & 1,976 & 1,920 & 1,943 & 1,930 & 1,882 & 1,953 & 1,979 \\
\hline Total & 7,718 & 7,914 & 7,792 & 7,926 & 7,762 & 7,963 & 7,790 & 7,733 & 8,049 & 8,030 & 8,100 & 8,120 & 8,099 & 8,110 & 8,194 \\
\hline Cátions & 15,718 & 15,798 & 15,785 & 15,852 & 15,737 & 15,827 & 15,757 & 15,727 & 15,921 & 15,910 & 15,773 & 15,809 & 15,932 & 15,961 & 15,919 \\
\hline CF & 0,607 & 0,527 & 0,220 & 0,670 & 0,551 & 0,497 & 0,316 & 0,527 & 0,357 & 0,332 & 0,366 & 0,533 & 0,271 & 0,718 & 0,216 \\
\hline $\mathrm{CCl}$ & 0,008 & 0,001 & 0,002 & 0,026 & 0,011 & 0,010 & 0,000 & 0,002 & 0,018 & 0,016 & 0,004 & 0,005 & 0,018 & 0,015 & 0,014 \\
\hline $\mathrm{Fe} \_\mathrm{FeMg}$ & 0,100 & 0,110 & 0,100 & 0,100 & 0,100 & 0,100 & 0,100 & 0,100 & 0,160 & 0,150 & 0,220 & 0,210 & 0,160 & 0,160 & 0,150 \\
\hline Mg_FeMg & 0,900 & 0,890 & 0,900 & 0,900 & 0,900 & 0,900 & 0,900 & 0,900 & 0,840 & 0,850 & 0,780 & 0,790 & 0,840 & 0,840 & 0,850 \\
\hline
\end{tabular}

$n=$ núcleo, $b=$ borda, int= entre núcleo e borda. Fórmula estrutural calculada com base em 22 oxigênios. 
Anexo 5: Análises químicas em flogopita (continuação).

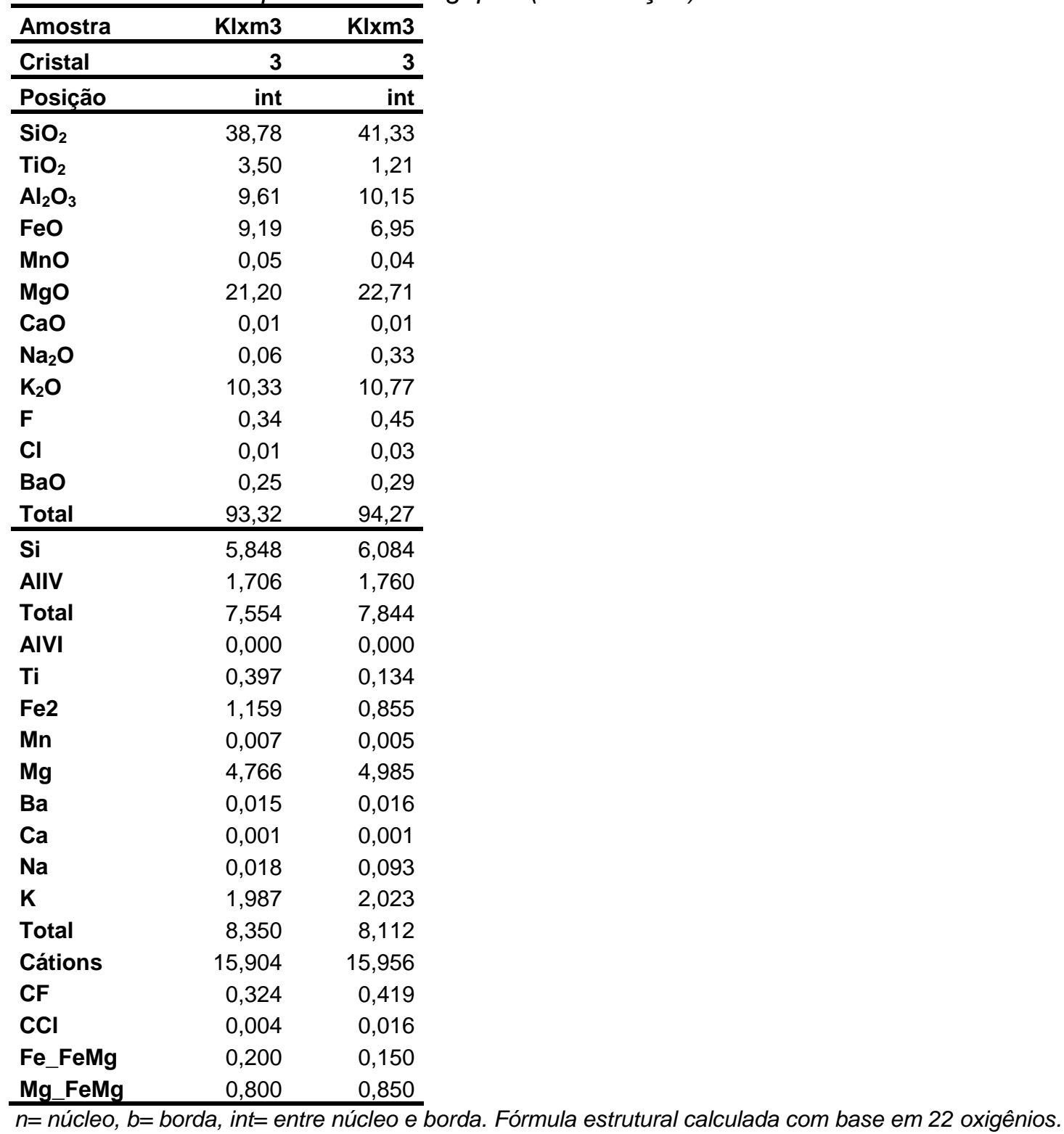


Anexo 6: Resultados de análises químicas (elementos maiores) em cristais de ilmenita de xenólitos do manto de Monte Carmelo.

\begin{tabular}{|c|c|c|c|c|c|c|c|}
\hline Amostra & KIxm2 & KIxm2 & KIxm2 & KIxm2 & KIxm3 & KIxm3 & KIxm3 \\
\hline Ponto & 20 & 21 & 22 & 23 & 37 & & \\
\hline $\mathrm{Nb}_{2} \mathrm{O}_{5}$ & 0,03 & 0,04 & 0,06 & 0,02 & 0,14 & 0,03 & 0,06 \\
\hline $\mathrm{SiO}_{2}$ & 0,02 & 0,07 & 0,00 & 0,02 & 0,04 & 0,02 & 0,02 \\
\hline $\mathrm{TiO}_{2}$ & 46,32 & 45,56 & 44,53 & 46,65 & 50,71 & 48,79 & 49,30 \\
\hline $\mathrm{ZrO}_{2}$ & 0,18 & 0,11 & 0,16 & 0,14 & 0,05 & 0,02 & 0,03 \\
\hline $\mathrm{Al}_{2} \mathrm{O}_{3}$ & 0,29 & 0,24 & 0,32 & 0,23 & 0,06 & 0,02 & 0,05 \\
\hline $\mathrm{Cr}_{2} \mathrm{O}_{3}$ & 9,13 & 9,25 & 9,21 & 8,62 & 1,78 & 0,52 & 0,46 \\
\hline MgO & 12,40 & 12,03 & 12,97 & 13,35 & 9,78 & 8,44 & 8,61 \\
\hline $\mathrm{CaO}$ & 0,08 & 0,33 & 0,06 & 0,08 & 0,05 & 0,02 & 0,02 \\
\hline MnO & 0,26 & 0,23 & 0,29 & 0,30 & 0,52 & 0,57 & 0,55 \\
\hline $\mathrm{FeO}$ & 30,02 & 30,58 & 31,35 & 29,87 & 36,92 & 38,22 & 37,82 \\
\hline SrO & 0,00 & 0,10 & 0,00 & 0,00 & 0,06 & 0,00 & 0,06 \\
\hline $\mathrm{BaO}$ & 0,06 & 0,11 & 0,02 & 0,01 & 0,07 & 0,24 & 0,02 \\
\hline $\mathrm{Na}_{2} \mathrm{O}$ & 0,20 & 0,12 & 0,11 & 0,12 & 0,01 & 0,06 & 0,09 \\
\hline $\mathrm{K}_{2} \mathrm{O}$ & 0,00 & 0,02 & 0,03 & 0,05 & 0,06 & 0,00 & 0,01 \\
\hline $\mathrm{La}_{2} \mathrm{O}_{3}$ & 0,01 & 0,02 & 0,05 & 0,00 & 0,02 & 0,01 & 0,00 \\
\hline $\mathrm{Ce}_{2} \mathrm{O}_{3}$ & 0,05 & 0,00 & 0,05 & 0,00 & 0,00 & 0,07 & 0,11 \\
\hline Zno & 0,11 & 0,02 & 0,07 & 0,07 & 0,06 & 0,02 & 0,04 \\
\hline Total & 99,14 & 98,83 & 99,27 & 99,51 & 100,31 & 97,06 & 97,24 \\
\hline $\mathrm{Nb}$ & 0,000 & 0,000 & 0,001 & 0,000 & 0,002 & 0,000 & 0,001 \\
\hline Si & 0,000 & 0,002 & 0,000 & 0,000 & 0,001 & 0,001 & 0,001 \\
\hline $\mathrm{Ti}$ & 0,833 & 0,826 & 0,805 & 0,833 & 0,916 & 0,922 & 0,926 \\
\hline $\mathrm{Zr}$ & 0,002 & 0,001 & 0,002 & 0,002 & 0,001 & 0,000 & 0,000 \\
\hline Al & 0,008 & 0,007 & 0,009 & 0,006 & 0,002 & 0,001 & 0,002 \\
\hline $\mathrm{Cr}$ & 0,173 & 0,176 & 0,175 & 0,162 & 0,034 & 0,010 & 0,009 \\
\hline Mg & 0,442 & 0,432 & 0,465 & 0,472 & 0,350 & 0,316 & 0,320 \\
\hline $\mathrm{Ca}$ & 0,002 & 0,008 & 0,002 & 0,002 & 0,001 & 0,001 & 0,001 \\
\hline Mn & 0,005 & 0,005 & 0,006 & 0,006 & 0,011 & 0,012 & 0,012 \\
\hline $\mathrm{Fe}$ & 0,600 & 0,616 & 0,630 & 0,593 & 0,742 & 0,803 & 0,790 \\
\hline $\mathrm{Sr}$ & 0,000 & 0,001 & 0,000 & 0,000 & 0,001 & 0,000 & 0,001 \\
\hline $\mathrm{Ba}$ & 0,001 & 0,001 & 0,000 & 0,000 & 0,001 & 0,002 & 0,000 \\
\hline $\mathrm{Na}$ & 0,009 & 0,006 & 0,005 & 0,006 & 0,000 & 0,003 & 0,004 \\
\hline K & 0,000 & 0,001 & 0,001 & 0,001 & 0,002 & 0,000 & 0,000 \\
\hline La & 0,000 & 0,000 & 0,000 & 0,000 & 0,000 & 0,000 & 0,000 \\
\hline $\mathrm{Ce}$ & 0,000 & 0,000 & 0,000 & 0,000 & 0,000 & 0,001 & 0,001 \\
\hline $\mathrm{Zn}$ & 0,004 & 0,001 & 0,002 & 0,002 & 0,002 & 0,001 & 0,001 \\
\hline Total & 2,080 & 2,083 & 2,104 & 2,086 & 2,064 & 2,072 & 2,069 \\
\hline $\mathrm{FeTiO}_{3}$ & 57,30 & 58,51 & 57,24 & 55,34 & 67,28 & 71,00 & 70,41 \\
\hline $\mathrm{MgTiO}_{3}$ & 42,19 & 41,04 & 42,23 & 44,09 & 31,76 & 27,93 & 28,56 \\
\hline $\mathrm{MnTiO}_{3}$ & 0,51 & 0,45 & 0,53 & 0,56 & 0,96 & 1,08 & 1,04 \\
\hline
\end{tabular}

Fórmula estrutural calculada com base em 3 oxigênios e 2 cátions. 
Anexo 7: Resultados de análises químicas (elementos maiores) em cristais de mathiasita de xenólitos do manto de Monte Carmelo.

\begin{tabular}{|c|c|c|c|c|c|c|c|c|c|c|}
\hline Amostra & KIxm2 & KIxm2 & KIxm2 & Klxm2 & $\mathrm{KIxm} 2$ & KIxm2 & KIxm2 & KIxm2 & KIxm2 & KIxm2 \\
\hline Ponto & 1 & 2 & 3 & 4 & 5 & 6 & 7 & 8 & 9 & 10 \\
\hline $\mathrm{Nb}_{2} \mathrm{O}_{5}$ & 0,18 & 0,21 & 0,25 & 0,23 & 0,17 & 0,21 & 0,20 & 0,18 & 0,19 & 0,14 \\
\hline $\mathrm{SiO}_{2}$ & 0,03 & 0,00 & 0,02 & 0,05 & 0,00 & 0,04 & 0,05 & 0,05 & 0,06 & 0,05 \\
\hline $\mathrm{TiO}_{2}$ & 59,25 & 60,24 & 56,14 & 59,09 & 53,01 & 60,40 & 58,56 & 57,82 & 59,77 & 59,09 \\
\hline $\mathrm{ZrO}_{2}$ & 5,94 & 5,83 & 6,66 & 5,19 & 5,28 & 5,80 & 5,83 & 5,76 & 5,66 & 5,82 \\
\hline $\mathrm{Al}_{2} \mathrm{O}_{3}$ & 0,76 & 0,82 & 0,66 & 0,81 & 0,71 & 0,77 & 0,78 & 0,76 & 0,76 & 0,77 \\
\hline $\mathrm{Cr}_{2} \mathrm{O}_{3}$ & 14,34 & 14,35 & 14,12 & 14,76 & 13,53 & 14,62 & 14,62 & 14,42 & 15,18 & 14,61 \\
\hline MgO & 3,27 & 3,29 & 2,45 & 2,14 & 3,11 & 3,18 & 3,22 & 2,49 & 3,22 & 3,24 \\
\hline $\mathrm{CaO}$ & 1,54 & 1,47 & 2,10 & 0,98 & 4,81 & 1,51 & 1,57 & 1,09 & 1,49 & 1,58 \\
\hline MnO & 0,12 & 0,11 & 0,03 & 0,03 & 0,12 & 0,07 & 0,09 & 0,07 & 0,07 & 0,05 \\
\hline $\mathrm{FeO}$ & 10,42 & 10,24 & 7,31 & 5,52 & 9,49 & 10,91 & 10,15 & 8,44 & 10,66 & 10,73 \\
\hline SrO & 0,70 & 0,62 & 0,75 & 0,48 & 0,83 & 0,61 & 0,54 & 0,40 & 0,71 & 0,68 \\
\hline $\mathrm{BaO}$ & 0,63 & 0,54 & 0,94 & 1,11 & 2,58 & 0,43 & 0,65 & 1,65 & 0,42 & 0,43 \\
\hline $\mathrm{Na}_{2} \mathrm{O}$ & 0,16 & 0,06 & 0,33 & 0,26 & 0,56 & 0,04 & 0,08 & 0,01 & 0,03 & 0,13 \\
\hline $\mathrm{K}_{2} \mathrm{O}$ & 1,77 & 0,84 & 5,69 & 7,37 & 4,37 & 0,86 & 0,91 & 4,92 & 0,90 & 0,97 \\
\hline $\mathrm{La}_{2} \mathrm{O}_{3}$ & 0,19 & 0,34 & 0,50 & 0,26 & 0,18 & 0,21 & 0,18 & 0,18 & 0,14 & 0,27 \\
\hline $\mathrm{Ce}_{2} \mathrm{O}_{3}$ & 0,23 & 0,27 & 0,55 & 0,40 & 0,23 & 0,32 & 0,32 & 0,22 & 0,23 & 0,34 \\
\hline Zno & 0,03 & 0,04 & 0,04 & 0,05 & $\mathrm{n}, \mathrm{a}$ & 0,01 & 0,00 & 0,01 & 0,01 & 0,00 \\
\hline total & 99,55 & 99,27 & 98,52 & 98,75 & 98,97 & 99,98 & 97,74 & 98,48 & 99,49 & 98,90 \\
\hline $\mathrm{Ca}(\mathrm{A})$ & 0,478 & 0,455 & 0,675 & 0,312 & 1,564 & 0,464 & 0,495 & 0,348 & 0,460 & 0,492 \\
\hline $\mathrm{Sr}$ & 0,117 & 0,104 & 0,130 & 0,082 & 0,146 & 0,101 & 0,091 & 0,070 & 0,118 & 0,114 \\
\hline $\mathrm{Ba}$ & 0,071 & 0,061 & 0,110 & 0,129 & 0,307 & 0,048 & 0,075 & 0,193 & 0,047 & 0,049 \\
\hline $\mathrm{Na}$ & 0,090 & 0,031 & 0,190 & 0,147 & 0,332 & 0,023 & 0,045 & 0,004 & 0,015 & 0,073 \\
\hline K & 0,655 & 0,311 & 2,178 & 2,787 & 1,690 & 0,313 & 0,342 & 1,869 & 0,332 & 0,360 \\
\hline La & 0,020 & 0,036 & 0,056 & 0,028 & 0,020 & 0,022 & 0,019 & 0,019 & 0,015 & 0,029 \\
\hline $\mathrm{Ce}$ & 0,024 & 0,029 & 0,060 & 0,044 & 0,025 & 0,034 & 0,034 & 0,024 & 0,024 & 0,036 \\
\hline total A & 1,457 & 1,026 & 3,400 & 3,530 & 4,084 & 1,006 & 1,102 & 2,527 & 1,011 & 1,153 \\
\hline $\mathrm{Nb}$ (M) & 0,023 & 0,027 & 0,034 & 0,031 & 0,024 & 0,027 & 0,026 & 0,024 & 0,025 & 0,019 \\
\hline Si & 0,010 & 0,000 & 0,006 & 0,016 & 0,000 & 0,012 & 0,016 & 0,013 & 0,016 & 0,015 \\
\hline $\mathrm{Ti}$ & 12,923 & 13,077 & 12,679 & 13,174 & 12,098 & 13,032 & 12,939 & 12,953 & 12,955 & 12,924 \\
\hline $\mathrm{Zr}$ & 0,839 & 0,820 & 0,974 & 0,750 & 0,780 & 0,811 & 0,835 & 0,836 & 0,796 & 0,824 \\
\hline Al & 0,260 & 0,278 & 0,233 & 0,282 & 0,253 & 0,260 & 0,270 & 0,268 & 0,259 & 0,264 \\
\hline $\mathrm{Cr}$ & 3,287 & 3,274 & 3,351 & 3,459 & 3,245 & 3,316 & 3,396 & 3,394 & 3,459 & 3,357 \\
\hline Mg & 1,411 & 1,416 & 1,095 & 0,945 & 1,405 & 1,359 & 1,411 & 1,106 & 1,384 & 1,404 \\
\hline Mn & 0,029 & 0,026 & 0,008 & 0,008 & 0,030 & 0,016 & 0,021 & 0,018 & 0,018 & 0,012 \\
\hline $\mathrm{Fe}$ & 2,526 & 2,472 & 1,836 & 1,368 & 2,407 & 2,618 & 2,492 & 2,103 & 2,569 & 2,609 \\
\hline Zn & 0,005 & 0,008 & 0,008 & 0,011 & 0,000 & 0,001 & 0,000 & 0,001 & 0,001 & 0,000 \\
\hline total M & 21,314 & 21,399 & 20,224 & 20,044 & 20,242 & 21,451 & 21,404 & 20,717 & 21,481 & 21,428 \\
\hline
\end{tabular}

Fórmula estrutural calculada com base em 38 oxigênios e 22 cátions. 
Anexo 7: Análises químicas em mathiasita (continuação).

\begin{tabular}{|c|c|c|c|c|c|c|c|c|}
\hline Amostra & Klxm2 & $\mathrm{KIxm} 2$ & KIxm2 & KIxm2 & KIxm2 & Klxm2 & KIxm2 & KIxm2 \\
\hline Ponto & 11 & 13 & 14 & 15 & 16 & 17 & & \\
\hline $\mathrm{Nb}_{2} \mathrm{O}_{5}$ & 0,24 & 0,18 & 0,17 & 0,22 & 0,16 & 0,17 & 0,21 & 0,15 \\
\hline $\mathrm{SiO}_{2}$ & 0,07 & 0,01 & 0,10 & 0,06 & 0,00 & 0,04 & 0,05 & 0,00 \\
\hline $\mathrm{TiO}_{2}$ & 59,00 & 60,10 & 58,81 & 54,87 & 59,52 & 59,47 & 59,61 & 58,84 \\
\hline $\mathrm{ZrO}_{2}$ & 5,90 & 6,12 & 6,02 & 5,64 & 6,09 & 6,02 & 5,84 & 5,77 \\
\hline $\mathrm{Al}_{2} \mathrm{O}_{3}$ & 0,84 & 0,76 & 0,82 & 0,74 & 0,79 & 0,81 & 0,78 & 0,82 \\
\hline $\mathrm{Cr}_{2} \mathrm{O}_{3}$ & 14,50 & 13,78 & 13,85 & 13,59 & 13,98 & 14,82 & 14,32 & 14,11 \\
\hline MgO & 3,15 & 3,36 & 3,21 & 4,07 & 3,40 & 3,25 & 3,12 & 3,26 \\
\hline $\mathrm{CaO}$ & 1,45 & 1,54 & 1,48 & 2,27 & 1,49 & 1,42 & 1,46 & 1,49 \\
\hline MnO & 0,08 & 0,04 & 0,03 & 0,14 & 0,08 & 0,09 & 0,10 & 0,10 \\
\hline $\mathrm{FeO}$ & 11,07 & 11,22 & 10,89 & 12,91 & 11,05 & 10,74 & 10,51 & 10,54 \\
\hline SrO & 0,70 & 0,41 & 0,78 & 0,74 & 0,57 & 0,64 & 0,71 & 0,60 \\
\hline $\mathrm{BaO}$ & 0,41 & 0,47 & 0,56 & 1,52 & 0,49 & 0,62 & 0,65 & 0,51 \\
\hline $\mathrm{Na}_{2} \mathrm{O}$ & 0,07 & 0,05 & 0,12 & 0,25 & 0,13 & 0,08 & 0,09 & 0,10 \\
\hline $\mathrm{K}_{2} \mathrm{O}$ & 0,85 & 1,02 & 0,87 & 1,49 & 1,02 & 0,82 & 1,05 & 0,79 \\
\hline $\mathrm{La}_{2} \mathrm{O}_{3}$ & 0,32 & 0,18 & 0,31 & 0,21 & 0,24 & 0,16 & 0,20 & 0,28 \\
\hline $\mathrm{Ce}_{2} \mathrm{O}_{3}$ & 0,32 & 0,35 & 0,28 & 0,29 & 0,23 & 0,33 & 0,23 & 0,32 \\
\hline Zno & 0,00 & 0,03 & $\mathrm{n}, \mathrm{a}$ & 0,05 & 0,00 & 0,04 & 0,00 & 0,00 \\
\hline total & 98,97 & 99,62 & 98,31 & 99,05 & 99,22 & 99,53 & 98,91 & 97,68 \\
\hline $\mathrm{Ca}(\mathrm{A})$ & 0,450 & 0,477 & 0,465 & 0,723 & 0,462 & 0,439 & 0,454 & 0,468 \\
\hline $\mathrm{Sr}$ & 0,117 & 0,068 & 0,132 & 0,127 & 0,096 & 0,107 & 0,120 & 0,101 \\
\hline $\mathrm{Ba}$ & 0,046 & 0,053 & 0,064 & 0,177 & 0,056 & 0,071 & 0,074 & 0,059 \\
\hline $\mathrm{Na}$ & 0,041 & 0,030 & 0,069 & 0,146 & 0,071 & 0,047 & 0,050 & 0,056 \\
\hline K & 0,317 & 0,375 & 0,326 & 0,566 & 0,377 & 0,303 & 0,390 & 0,298 \\
\hline La & 0,035 & 0,019 & 0,034 & 0,023 & 0,025 & 0,017 & 0,021 & 0,031 \\
\hline $\mathrm{Ce}$ & 0,034 & 0,037 & 0,030 & 0,031 & 0,024 & 0,035 & 0,024 & 0,034 \\
\hline total A & 1,040 & 1,058 & 1,120 & 1,794 & 1,110 & 1,019 & 1,134 & 1,047 \\
\hline $\mathrm{Nb}(\mathrm{M})$ & 0,032 & 0,023 & 0,023 & 0,029 & 0,021 & 0,022 & 0,028 & 0,020 \\
\hline Si & 0,019 & 0,004 & 0,028 & 0,018 & 0,000 & 0,012 & 0,013 & 0,000 \\
\hline $\mathrm{Ti}$ & 12,903 & 13,033 & 12,953 & 12,275 & 12,973 & 12,921 & 13,026 & 13,004 \\
\hline $\mathrm{Zr}$ & 0,836 & 0,861 & 0,859 & 0,818 & 0,861 & 0,848 & 0,827 & 0,827 \\
\hline Al & 0,287 & 0,259 & 0,282 & 0,261 & 0,268 & 0,275 & 0,266 & 0,284 \\
\hline $\mathrm{Cr}$ & 3,333 & 3,141 & 3,206 & 3,194 & 3,202 & 3,385 & 3,288 & 3,278 \\
\hline Mg & 1,366 & 1,443 & 1,401 & 1,803 & 1,468 & 1,398 & 1,353 & 1,427 \\
\hline Mn & 0,020 & 0,010 & 0,008 & 0,035 & 0,018 & 0,022 & 0,023 & 0,026 \\
\hline $\mathrm{Fe}$ & 2,690 & 2,705 & 2,667 & 3,211 & 2,677 & 2,593 & 2,553 & 2,589 \\
\hline Zn & 0,000 & 0,006 & 0,000 & 0,010 & 0,000 & 0,009 & 0,000 & 0,000 \\
\hline total M & 21,488 & 21,485 & 21,427 & 21,653 & 21,488 & 21,485 & 21,378 & 21,455 \\
\hline
\end{tabular}

Fórmula estrutural calculada com base em 38 oxigênios e 22 cátions. 
Anexo 8: Resultados de análises químicas (elementos maiores) em cristais de priderita de xenólitos do manto de Monte Carmelo.

\begin{tabular}{|c|c|c|c|c|c|c|c|c|c|}
\hline Amostra & KIxm3 & KIxm3 & KIxm3 & KIxm3 & KIxm3 & KIxm3 & KIxm3 & KIxm3 & KIxm3 \\
\hline Ponto & 25 & 26 & 27 & 28 & 29 & 31 & 32 & 33 & 34 \\
\hline $\mathrm{Nb}_{2} \mathrm{O}_{5}$ & 3,39 & 3,40 & 2,97 & 3,58 & 3,97 & 1,67 & 2,47 & 1,84 & 2,41 \\
\hline $\mathrm{SiO}_{2}$ & 0,10 & 0,05 & 0,00 & 0,00 & 0,05 & 0,00 & 0,00 & 0,00 & 0,00 \\
\hline $\mathrm{TiO}_{2}$ & 70,32 & 70,89 & 75,68 & 71,15 & 69,28 & 74,61 & 91,64 & 76,43 & 76,28 \\
\hline $\mathrm{ZrO}_{2}$ & 0,10 & 0,10 & 0,13 & 0,11 & 0,15 & 0,32 & 0,34 & 0,31 & 0,49 \\
\hline $\mathrm{Al}_{2} \mathrm{O}_{3}$ & 0,04 & 0,07 & 0,04 & 0,04 & 0,08 & 0,16 & 0,01 & 0,00 & 0,00 \\
\hline $\mathrm{Cr}_{2} \mathrm{O}_{3}$ & 2,36 & 2,21 & 1,87 & 2,06 & 2,58 & 1,69 & 1,40 & 1,19 & 1,02 \\
\hline MgO & 0,75 & 0,72 & 1,21 & 1,20 & 0,97 & 1,44 & 0,46 & 0,64 & 1,08 \\
\hline $\mathrm{CaO}$ & 0,82 & 0,48 & 0,03 & 0,17 & 0,58 & 0,73 & 0,12 & 0,01 & 0,06 \\
\hline MnO & 0,00 & 0,00 & 0,01 & 0,02 & 0,00 & 0,00 & 0,05 & 0,00 & 0,00 \\
\hline $\mathrm{FeO}$ & 9,34 & 9,76 & 7,42 & 8,66 & 10,08 & 7,92 & 0,97 & 4,15 & 4,54 \\
\hline SrO & 0,04 & 0,06 & 0,00 & 0,00 & 0,12 & 0,11 & 0,02 & 0,08 & 0,03 \\
\hline $\mathrm{BaO}$ & 0,43 & 0,60 & 0,39 & 0,37 & 0,61 & 1,31 & 0,17 & 1,18 & 0,87 \\
\hline $\mathrm{Na}_{2} \mathrm{O}$ & 0,57 & 0,46 & 0,31 & 0,49 & 0,57 & 0,06 & 0,02 & 0,23 & 0,12 \\
\hline $\mathrm{K}_{2} \mathrm{O}$ & 8,67 & 8,57 & 8,72 & 8,62 & 8,90 & 8,20 & 2,44 & 11,84 & 10,21 \\
\hline $\mathrm{La}_{2} \mathrm{O}_{3}$ & 0,00 & 0,00 & 0,00 & 0,00 & 0,04 & 0,02 & 0,00 & 0,00 & 0,00 \\
\hline $\mathrm{Ce}_{2} \mathrm{O}_{3}$ & 0,06 & 0,08 & 0,07 & 0,05 & 0,00 & 0,09 & 0,00 & 0,12 & 0,08 \\
\hline ZnO & 0,00 & 0,00 & 0,00 & 0,02 & 0,00 & 0,04 & 0,00 & 0,00 & 0,03 \\
\hline total & 96,97 & 97,45 & 98,85 & 96,53 & 97,96 & 98,36 & 100,10 & 98,01 & 97,23 \\
\hline $\mathrm{Ca}(\mathrm{A})$ & 0,109 & 0,063 & 0,004 & 0,022 & 0,076 & 0,095 & 0,014 & 0,002 & 0,008 \\
\hline $\mathrm{Sr}$ & 0,003 & 0,004 & 0,000 & 0,000 & 0,008 & 0,008 & 0,001 & 0,006 & 0,002 \\
\hline $\mathrm{Ba}$ & 0,021 & 0,029 & 0,018 & 0,018 & 0,030 & 0,062 & 0,007 & 0,056 & 0,042 \\
\hline $\mathrm{Na}$ & 0,137 & 0,110 & 0,072 & 0,118 & 0,137 & 0,013 & 0,003 & 0,054 & 0,029 \\
\hline $\mathrm{K}$ & 1,372 & 1,351 & 1,331 & 1,363 & 1,405 & 1,265 & 0,341 & 1,837 & 1,583 \\
\hline La & 0,000 & 0,000 & 0,000 & 0,000 & 0,002 & 0,001 & 0,000 & 0,000 & 0,000 \\
\hline $\mathrm{Ce}$ & 0,003 & 0,004 & 0,003 & 0,002 & 0,000 & 0,004 & 0,000 & 0,005 & 0,004 \\
\hline total A & 1,645 & 1,561 & 1,428 & 1,524 & 1,658 & 1,448 & 0,367 & 1,960 & 1,667 \\
\hline $\mathrm{Nb}(\mathrm{M})$ & 0,190 & 0,190 & 0,161 & 0,201 & 0,222 & 0,091 & 0,122 & 0,101 & 0,132 \\
\hline Si & 0,012 & 0,007 & 0,000 & 0,000 & 0,007 & 0,000 & 0,000 & 0,000 & 0,000 \\
\hline $\mathrm{Ti}$ & 6,567 & 6,593 & 6,811 & 6,634 & 6,454 & 6,791 & 7,556 & 6,992 & 6,971 \\
\hline $\mathrm{Zr}$ & 0,006 & 0,006 & 0,007 & 0,007 & 0,009 & 0,019 & 0,018 & 0,018 & 0,029 \\
\hline Al & 0,006 & 0,010 & 0,006 & 0,005 & 0,011 & 0,023 & 0,001 & 0,000 & 0,000 \\
\hline $\mathrm{Cr}$ & 0,231 & 0,216 & 0,177 & 0,202 & 0,252 & 0,161 & 0,121 & 0,114 & 0,097 \\
\hline $\mathbf{M g}$ & 0,139 & 0,132 & 0,216 & 0,222 & 0,179 & 0,260 & 0,076 & 0,116 & 0,195 \\
\hline Mn & 0,000 & 0,000 & 0,001 & 0,002 & 0,000 & 0,000 & 0,005 & 0,000 & 0,000 \\
\hline $\mathrm{Fe}$ & 0,969 & 1,009 & 0,742 & 0,898 & 1,044 & 0,802 & 0,089 & 0,422 & 0,461 \\
\hline $\mathrm{Zn}$ & 0,000 & 0,000 & 0,000 & 0,002 & 0,000 & 0,003 & 0,000 & 0,000 & 0,003 \\
\hline total $M$ & 8,120 & 8,164 & 8,121 & 8,171 & 8,178 & 8,150 & 7,987 & 7,764 & 7,890 \\
\hline $\mathrm{K} /(\mathrm{K}+\mathrm{Ba})$ & 0,985 & 0,979 & 0,987 & 0,987 & 0,979 & 0,953 & 0,979 & 0,970 & 0,974 \\
\hline
\end{tabular}

Fórmula estrutural calculada com base em 16 oxigênios e 9,5 cátions. 
Anexo 8: Análises químicas em priderita (continuação).

\begin{tabular}{|c|c|c|c|c|c|}
\hline Amostra & Klxm3 & KIxm3 & KIxm3 & KIxm3 & Klxm3 \\
\hline Ponto & 35 & 36 & & & \\
\hline $\mathrm{Nb}_{2} \mathrm{O}_{5}$ & 1,56 & 1,94 & 3,42 & 3,08 & 1,48 \\
\hline $\mathrm{SiO}_{2}$ & 0,04 & 0,00 & 0,00 & 0,01 & 0,00 \\
\hline $\mathrm{TiO}_{2}$ & 79,94 & 75,85 & 71,14 & 69,32 & 84,75 \\
\hline $\mathrm{ZrO}_{2}$ & 0,36 & 0,35 & 0,13 & 0,21 & 0,34 \\
\hline $\mathrm{Al}_{2} \mathrm{O}_{3}$ & 0,04 & 0,06 & 0,01 & 0,16 & 0,10 \\
\hline $\mathrm{Cr}_{2} \mathrm{O}_{3}$ & 1,49 & 1,77 & 2,52 & 1,62 & 2,09 \\
\hline MgO & 0,52 & 1,30 & 2,05 & 1,20 & 2,21 \\
\hline $\mathrm{CaO}$ & 0,02 & 0,14 & 0,04 & 1,75 & 0,06 \\
\hline MnO & 0,00 & 0,00 & 0,06 & 0,00 & 0,12 \\
\hline $\mathrm{FeO}$ & 3,12 & 7,47 & 10,10 & 8,67 & 0,98 \\
\hline SrO & 0,03 & 0,01 & 0,09 & 0,28 & 0,00 \\
\hline $\mathrm{BaO}$ & 0,96 & 1,13 & 0,33 & 0,96 & 0,23 \\
\hline $\mathrm{Na}_{2} \mathrm{O}$ & 0,22 & 0,08 & 0,37 & 0,43 & 0,04 \\
\hline $\mathrm{K}_{2} \mathrm{O}$ & 12,08 & 8,64 & 8,08 & 8,17 & 5,46 \\
\hline $\mathrm{La}_{2} \mathrm{O}_{3}$ & 0,08 & 0,02 & 0,00 & 0,00 & 0,00 \\
\hline $\mathrm{Ce}_{2} \mathrm{O}_{3}$ & 0,03 & 0,06 & 0,07 & 0,06 & 0,06 \\
\hline Zno & 0,04 & 0,04 & 0,00 & 0,03 & 0,04 \\
\hline total & 100,51 & 98,86 & 98,42 & 95,94 & 97,97 \\
\hline $\mathrm{Ca}(\mathrm{A})$ & 0,002 & 0,018 & 0,005 & 0,236 & 0,007 \\
\hline $\mathrm{Sr}$ & 0,002 & 0,001 & 0,006 & 0,020 & 0,000 \\
\hline $\mathrm{Ba}$ & 0,044 & 0,053 & 0,016 & 0,047 & 0,010 \\
\hline $\mathrm{Na}$ & 0,049 & 0,020 & 0,088 & 0,104 & 0,009 \\
\hline $\mathrm{K}$ & 1,812 & 1,323 & 1,256 & 1,309 & 0,795 \\
\hline La & 0,003 & 0,001 & 0,000 & 0,000 & 0,000 \\
\hline $\mathrm{Ce}$ & 0,001 & 0,002 & 0,003 & 0,003 & 0,003 \\
\hline total A & 1,914 & 1,417 & 1,374 & 1,719 & 0,824 \\
\hline $\mathrm{Nb}(\mathrm{M})$ & 0,083 & 0,105 & 0,189 & 0,175 & 0,077 \\
\hline Si & 0,005 & 0,000 & 0,000 & 0,001 & 0,000 \\
\hline $\mathrm{Ti}$ & 7,069 & 6,849 & 6,517 & 6,552 & 7,280 \\
\hline $\mathrm{Zr}$ & 0,021 & 0,021 & 0,008 & 0,013 & 0,019 \\
\hline Al & 0,006 & 0,008 & 0,002 & 0,024 & 0,013 \\
\hline $\mathrm{Cr}$ & 0,138 & 0,168 & 0,243 & 0,161 & 0,189 \\
\hline Mg & 0,091 & 0,233 & 0,373 & 0,225 & 0,376 \\
\hline Mn & 0,000 & 0,000 & 0,006 & 0,000 & 0,011 \\
\hline $\mathrm{Fe}$ & 0,306 & 0,750 & 1,029 & 0,911 & 0,094 \\
\hline $\mathrm{Zn}$ & 0,003 & 0,003 & 0,000 & 0,003 & 0,004 \\
\hline total M & 7,722 & 8,137 & 8,366 & 8,065 & 8,062 \\
\hline $\mathrm{K}(\mathrm{K} / \mathrm{Ba})$ & 0,976 & 0,961 & 0,988 & 0,965 & 0,987 \\
\hline
\end{tabular}

Fórmula estrutural calculada com base em 16 oxigênios e 9,5 cátions. 
Anexo 9: Resultados de análises químicas (elementos maiores) de fases acessórias de xenólitos do manto de Monte Carmelo.

\begin{tabular}{|c|c|c|c|c|c|c|}
\hline Amostra & KIxm2 & KIxm2 & KIxm3 & KIxm3 & KIxm3 & Costa (1996) \\
\hline ponto & 18 & 19 & & & & \\
\hline $\mathrm{Nb}_{2} \mathrm{O}_{5}$ & 0,28 & 0,14 & 1,39 & 0,67 & 0,06 & \\
\hline $\mathrm{SiO}_{2}$ & 0,33 & 0,20 & 3,67 & 6,10 & 4,68 & 3,7 \\
\hline $\mathrm{TiO}_{2}$ & 45,48 & 35,67 & 49,66 & 44,27 & 37,41 & 54,41 \\
\hline $\mathrm{ZrO}_{2}$ & 6,60 & 2,72 & 0,13 & 0,08 & 0,05 & \\
\hline $\mathrm{Al}_{2} \mathrm{O}_{3}$ & 0,28 & 0,71 & 0,18 & 0,40 & 0,18 & 0,05 \\
\hline $\mathrm{Cr}_{2} \mathrm{O}_{3}$ & 6,27 & 9,15 & 0,29 & 0,06 & 4,27 & \\
\hline MgO & 8,29 & 3,94 & 1,55 & 3,11 & 1,97 & 0,04 \\
\hline $\mathrm{CaO}$ & 6,92 & 21,52 & 33,72 & 31,90 & 21,48 & 36,5 \\
\hline $\mathrm{MnO}$ & 0,29 & 0,60 & 0,01 & 0,05 & 0,19 & \\
\hline $\mathrm{FeO}$ & 19,28 & 20,97 & 1,59 & 2,03 & 17,37 & 1,11 \\
\hline SrO & 1,33 & 1,65 & 2,86 & 3,18 & 1,69 & \\
\hline $\mathrm{BaO}$ & 0,92 & 0,17 & 0,34 & 0,70 & 0,21 & \\
\hline $\mathrm{Na}_{2} \mathrm{O}$ & 0,64 & 1,02 & 1,58 & 2,03 & 0,97 & 0,51 \\
\hline $\mathrm{K}_{2} \mathrm{O}$ & 0,96 & 0,14 & 0,29 & 0,56 & 0,06 & \\
\hline $\mathrm{La}_{2} \mathrm{O}_{3}$ & 0,35 & 0,32 & 0,29 & 0,25 & 0,00 & 0,99 \\
\hline $\mathrm{Ce}_{2} \mathrm{O}_{3}$ & 0,49 & 0,50 & 0,30 & 0,38 & 0,00 & 2,66 \\
\hline Zno & 0,00 & 0,11 & 0,05 & 0,00 & 0,02 & \\
\hline Total & 98,69 & 99,53 & 97,89 & 95,77 & 90,59 & 99,97 \\
\hline
\end{tabular}


Anexo 10: Análises químicas de rocha total dos xenólitos do Kimberlito Limeira 1 (Klxm1 e KIxm2) e do kimberlito por ICP-OES (elementos maiores e menores) e ICP-MS (elementos traços).

\begin{tabular}{|c|c|c|c|c|c|}
\hline Amostra & KIxm1 & KIxm2 & Kimberlito & \multicolumn{2}{|c|}{ Carlson et al,, (2007) } \\
\hline $\mathrm{SiO}_{2}(\%)$ & 40,60 & 39,91 & 30,92 & $\mathrm{SiO}_{2}(\%)$ & 39,75 \\
\hline $\mathrm{TiO}_{2}$ & 0,01 & 0,54 & 2,29 & $\mathrm{TiO}_{2}$ & 0,24 \\
\hline $\mathrm{Al}_{2} \mathrm{O}_{3}$ & 0,85 & 0,78 & 1,89 & $\mathrm{Al}_{2} \mathrm{O}_{3}$ & 0,91 \\
\hline $\mathrm{Fe}_{2} \mathrm{O}_{3}(\mathrm{~T})$ & 7,81 & 10,34 & 11,10 & $\mathrm{Fe}_{2} \mathrm{O}_{3}$ & 1,64 \\
\hline MnO & 0,12 & 0,15 & 0,22 & $\mathrm{FeO}$ & 10,25 \\
\hline MgO & 43,17 & 40,62 & 31,03 & MnO & 0,19 \\
\hline $\mathrm{CaO}$ & 2,59 & 3,34 & 10,48 & MgO & 40,00 \\
\hline $\mathrm{Na}_{2} \mathrm{O}$ & 0,08 & 0,05 & $<0,01$ & $\mathrm{CaO}$ & 3,12 \\
\hline $\mathrm{K}_{2} \mathrm{O}$ & 0,38 & 0,37 & 0,66 & $\mathrm{Na}_{2} \mathrm{O}$ & 0,22 \\
\hline $\mathrm{P}_{2} \mathrm{O}_{5}$ & 0,03 & 0,19 & 2,28 & $\mathrm{~K}_{2} \mathrm{O}$ & 0,13 \\
\hline LOI & 5,16 & 4,79 & 10,58 & $\mathrm{P}_{2} \mathrm{O}_{5}$ & 0,18 \\
\hline Total & 100,78 & 101,08 & 101,45 & LOI & 2,67 \\
\hline $\mathrm{Rb}(\mathrm{ppm})$ & 40,7 & 36,8 & 95,5 & Total & 99,30 \\
\hline $\mathrm{Sr}$ & 391 & 307 & 2105 & Sr(ppm) & 204 \\
\hline$Y$ & 1,26 & 4,76 & 33,5 & $Z r$ & 46 \\
\hline $\mathrm{Zr}$ & 3,86 & 407 & 633 & v & 81 \\
\hline Nb & 1,72 & 22,5 & 197 & $\mathrm{Ni}$ & 2685 \\
\hline Cs & 0,40 & 0,33 & 1,57 & $\mathrm{Cr}$ & 1445 \\
\hline $\mathrm{Ba}$ & 271 & 327 & 1911 & Co & 109 \\
\hline La & 2,06 & 32,9 & 267 & $\operatorname{Re}(\mathrm{ppb})$ & 2,06 \\
\hline $\mathrm{Ce}$ & 3,16 & 57,5 & 559 & Os(ppb) & 4,09 \\
\hline $\mathrm{Pr}$ & 0,32 & 6,49 & 57,7 & & \\
\hline Nd & 1,21 & 23,5 & 229 & & \\
\hline Sm & 0,23 & 3,34 & 32,2 & & \\
\hline Eu & 0,08 & 0,86 & 7,95 & & \\
\hline Gd & 0,25 & 2,30 & 22,3 & & \\
\hline Tb & 0,03 & 0,27 & 2,29 & & \\
\hline Dy & 0,19 & 1,24 & 10,3 & & \\
\hline Ho & 0,04 & 0,19 & 1,47 & & \\
\hline $\mathrm{Er}$ & 0,09 & 0,47 & 3,65 & & \\
\hline $\mathrm{Tm}$ & 0,01 & 0,05 & 0,35 & & \\
\hline $\mathrm{Yb}$ & 0,08 & 0,26 & 1,78 & & \\
\hline Lu & 0,01 & 0,04 & 0,26 & & \\
\hline $\mathrm{Hf}$ & 0,08 & 10,9 & 14,3 & & \\
\hline $\mathrm{Ta}$ & 0,32 & 1,91 & 12,7 & & \\
\hline $\mathbf{P b}$ & 1,20 & 2,28 & 10,3 & & \\
\hline Th & 0,11 & 2,48 & 26,0 & & \\
\hline u & 0,08 & 0,75 & 5,37 & & \\
\hline$(\mathrm{La} / \mathrm{Yb})_{\mathrm{N}}$ & 18,31 & 86,20 & 101,36 & & \\
\hline
\end{tabular}


Anexo 11: Análises químicas de elementos traços em cristais de olivina de xenólitos do manto de Ubatuba e Monte Carmelo por LA-ICPMS.

\begin{tabular}{|c|c|c|c|c|c|c|c|}
\hline Amostra & Ln9xm1 & Ln9xm1 & Ln9xm2 & Ln9xm3 & Ln9xm3 & KIxm1 & KIxm1 \\
\hline Li & 2,34 & 2,63 & 7,36 & $<$ l.d. & $<$ l.d. & 1,29 & 1,02 \\
\hline $\mathrm{Be}$ & $<$ l.d. & $<$ l.d. & $<$ l.d. & $<$ l.d. & $<$ l.d. & $<$. .l.d. & $<$ <.l.d. \\
\hline $\mathrm{Mg}$ & 300038,6 & 304905,66 & 289520,44 & $48,92(\%)$ & $48,86(\%)$ & 303952,75 & 306335 \\
\hline $\mathbf{P}$ & 67,62 & 56,07 & 57,15 & 74,17 & 66,79 & 53,19 & 43,35 \\
\hline $\mathrm{Ca}$ & 155,81 & $<$ l.d. & $<$ l.d. & $<$ l.d. & $<$ l.d. & $<$. .l.d. & $<$.l.d. \\
\hline Sc & 1,45 & 1,75 & 1,57 & 2,22 & 2,54 & 2,1 & 2,27 \\
\hline $\mathrm{Ti}$ & 3,89 & 3,77 & 4,99 & 29,06 & 35,41 & $<$.l.d. & $<. l . d$. \\
\hline v & 1,15 & 1,46 & 0,69 & 1,35 & 1,18 & 0,41 & $<. I . d$. \\
\hline $\mathrm{Cr}$ & 24,59 & 24,96 & 21,78 & 8,08 & $<$ l.d. & 4,31 & 7,12 \\
\hline Mn & 1110,18 & 1123,62 & 1886,87 & 1125,34 & 1094,72 & 952,65 & 895,82 \\
\hline Co & 160,95 & 156,63 & 148,28 & 160,67 & 159,89 & 144,12 & 139,71 \\
\hline $\mathrm{Ni}$ & 3335,45 & 3202,58 & 2483,52 & 3295,8 & 3283,64 & 3240,82 & 3216,83 \\
\hline $\mathrm{Cu}$ & 0,68 & 1,14 & 0,45 & $<$ l.d. & $<$ l.d. & 0,26 & 0,3 \\
\hline $\mathrm{Zn}$ & 42,79 & 45,26 & 120,45 & 30,68 & 32,57 & 23,56 & 23,29 \\
\hline $\mathbf{G a}$ & $<$ l.d. & 0,096 & $<$ l.d. & $<$ l.d. & 0,145 & $<. I . d$. & 0,021 \\
\hline $\mathbf{R b}$ & $<$ l.d. & $<$ l.d. & $<$ l.d. & $<$ l.d. & $<$ l.d. & $<$. l.d. & $<$.l.d. \\
\hline $\mathrm{Sr}$ & $<$ l.d. & $<$ l.d. & $<$ l.d. & 0,0078 & $<$ l.d. & $<$. l.d. & $<. l . d$. \\
\hline $\mathbf{Y}$ & 0,0185 & $<$ l.d. & 0,097 & 0,042 & $<$ l.d. & $<$.l.d. & $<. I . d$. \\
\hline $\mathrm{Zr}$ & 0,0094 & $<$ l.d. & $<$ l.d. & $<$ l.d. & $<$ l.d. & $<. l . d$ & $<$. I.d. \\
\hline $\mathrm{Nb}$ & 0,021 & $<$ l.d. & $<$ l.d. & 0,03 & $<$ l.d. & 0,0077 & $<. l . d$. \\
\hline Mo & $<$ l.d. & 0,036 & $<$ l.d. & $<$ l.d. & $<$ l.d. & 0,023 & $<$.l.d. \\
\hline Sn & 1,15 & 0,73 & $<$ l.d. & 1,61 & 1,77 & 0,87 & 1,04 \\
\hline Sb & $<$ l.d. & $<$ l.d. & $<$ l.d. & $<$ l.d. & $<$ l.d. & $<$. l.d. & $<$.l.d. \\
\hline Cs & $<$ l.d. & $<$ l.d. & $<$ l.d. & $<$ l.d. & $<$ l.d. & 0,0054 & 0,0023 \\
\hline $\mathrm{Ba}$ & 0,031 & $<$ l.d. & 0,055 & $<$ l.d. & $<$ l.d. & $<$. l.d. & $<$.l.d. \\
\hline La & $<$ l.d. & $<$ l.d. & $<$ l.d. & $<$ l.d. & $<$ l.d. & $<$. l.d. & $<$.l.d. \\
\hline $\mathrm{Ce}$ & $<$ l.d. & 0,0048 & 0,015 & $<$ l.d. & 0,009 & 0,0032 & $<. l . d$. \\
\hline $\mathrm{Pr}$ & $<$ l.d. & $<$ l.d. & $<$ l.d. & $<$ l.d. & $<$ l.d. & 0,0025 & $<$.l.d. \\
\hline Nd & $<$ l.d. & $<$ l.d. & $<$ l.d. & $<$ l.d. & 0,066 & $<$. l.d. & 0,038 \\
\hline Sm & $<$ l.d. & $<$ l.d. & $<$ l.d. & $<$ l.d. & 0,054 & $<$. l.d. & 0,015 \\
\hline $\mathrm{Eu}$ & $<$ l.d. & $<$ l.d. & $<$ l.d. & $<$ l.d. & 0,079 & 0,0054 & $<$.l.d. \\
\hline Gd & $<$ l.d. & $<$ l.d. & $<$ l.d. & 0,23 & 0,071 & $<$.l.d. & 0,017 \\
\hline Tb & $<$ l.d. & $<$ l.d. & $<$ l.d. & 0,0069 & 0,017 & $<$. l.d. & 0,0022 \\
\hline Dy & $<$ l.d. & 0,015 & 0,023 & 0,086 & $<$ l.d. & $<. I . d$. & $<$.l.d. \\
\hline Ho & $<$ l.d. & 0,0039 & $<$ l.d. & 0,014 & 0,027 & $<. I . d$. & $<. l . d$. \\
\hline $\mathrm{Er}$ & $<$ l.d. & 0,011 & $<$ l.d. & $<$ l.d. & $<$ l.d. & $<. l . d$ & $<$. I.d. \\
\hline $\mathrm{Tm}$ & $<$ l.d. & $<$ l.d. & $<$ l.d. & $<$ l.d. & $<$ l.d. & $<$.l.d. & $<. l . d$. \\
\hline $\mathrm{Yb}$ & $<$ l.d. & 0,049 & $<$ l.d. & 0,092 & 0,057 & $<$.l.d. & $<. I . d$. \\
\hline Lu & 0,0035 & 0,004 & 0,0122 & 0,0076 & $<$ l.d. & $<. l . d$ & 0,0022 \\
\hline $\mathrm{Hf}$ & $<$ l.d. & $<$ l.d. & 0,043 & $<$ l.d. & 0,06 & $<$. l.d. & $<$.l.d. \\
\hline $\mathrm{Ta}$ & 0,0034 & 0,0039 & $<$ l.d. & $<$ l.d. & $<$ l.d. & $<$. l.d. & $<$.l.d. \\
\hline $\mathbf{P b}$ & $<$ l.d. & 0,05 & $<$ l.d. & $<$ l.d. & $<$ l.d. & $<. I . d$. & $<$. I.d. \\
\hline Th & $<$ l.d. & $<$ l.d. & 0,039 & 0,0077 & $<$ l.d. & $<. l . d$ & $<. I . d$. \\
\hline $\mathbf{U}$ & 0,06 & $<$ l.d. & $<$ l.d. & 0,02 & $<$ l.d. & $<$ l. d. & $<$.l.d. \\
\hline
\end{tabular}

Concentrações em ppm. 
Anexo 12: Análises químicas de elementos traços em cristais de ortopiroxênio de xenólitos de Ubatuba e Monte Carmelo por LA-ICPMS.

\begin{tabular}{|c|c|c|c|c|c|c|}
\hline Amostra & Ln9xm3 & Ln9xm3 & Ln9xm3 & Ln9xm3 & Ln9xm1 & Ln9xm1 \\
\hline Li & $<$ l.d. & 1,34 & 1,41 & 1,82 & 2,16 & 2,03 \\
\hline $\mathrm{Be}$ & 0,82 & $<$ l.d. & $<$ l.d. & 2,43 & 0,52 & $<$ l.d. \\
\hline Mg & $32,53(\%)$ & $33(\%)$ & $32,63(\%)$ & $32,62(\%)$ & 199193,44 & 197414,3 \\
\hline $\mathbf{P}$ & 67,23 & 86,16 & 39,55 & 55,76 & 30,4 & 50,66 \\
\hline $\mathrm{Ca}$ & 4771,67 & 4094,19 & 4398,65 & 2841,43 & 2770,15 & 3390,17 \\
\hline Sc & 16,35 & 16,53 & 17,38 & 15,97 & 13,5 & 14,67 \\
\hline $\mathrm{Ti}$ & 1058,98 & 1024,07 & 1078,67 & 975,67 & 364,8 & 422,58 \\
\hline V & 106,5 & 100,35 & 107,54 & 102,88 & 89,9 & 99,35 \\
\hline $\mathrm{Cr}$ & 2117,13 & 2130,04 & 2421,86 & 2272,02 & 2923,96 & 3016,29 \\
\hline Mn & 1177,6 & 1186,19 & 1150,63 & 1173,95 & 1139,93 & 1121,64 \\
\hline Co & 59,3 & 58,8 & 60,49 & 57,76 & 57,06 & 55,76 \\
\hline $\mathrm{Ni}$ & 637,07 & 672,8 & 688,14 & 649,85 & 632,18 & 642,36 \\
\hline $\mathrm{Cu}$ & 0,77 & 0,62 & 0,65 & $<$ l.d. & 0,32 & 0,76 \\
\hline $\mathrm{Zn}$ & 22,71 & 24,77 & 28,25 & 23,38 & 31,55 & 26,52 \\
\hline $\mathbf{G a}$ & 3,81 & 3,58 & 4,19 & 3,74 & 3,19 & 3,18 \\
\hline $\mathbf{R b}$ & $<$ l.d. & $<$ l.d. & $<$ l.d. & $<$ l.d. & $<$ l.d. & $<$ l.d. \\
\hline $\mathrm{Sr}$ & 0,342 & 0,298 & 0,276 & $<$ l.d. & 1,188 & 0,26 \\
\hline $\mathbf{Y}$ & 0,86 & 0,782 & 0,9 & 0,676 & 0,271 & 0,351 \\
\hline $\mathrm{Zr}$ & 0,92 & 0,93 & 0,81 & 0,66 & 0,607 & 0,646 \\
\hline $\mathrm{Nb}$ & $<$ l.d. & $<$ l.d. & 0,038 & $<$ l.d. & $<$ l.d. & 0,0047 \\
\hline Mo & 0,2 & 0,125 & $<$ l.d. & $<$ l.d. & $<$ l.d. & $<$ l.d. \\
\hline Sn & $<$ l.d. & $<$ l.d. & $<$ l.d. & $<$ l.d. & 0,66 & 0,69 \\
\hline Sb & $<$ l.d. & 0,028 & $<$ l.d. & $<$ l.d. & $<$ l.d. & 0,059 \\
\hline Cs & $<$ l.d. & $<$ l.d. & 0,046 & $<$ l.d. & $<$ l.d. & 0,0159 \\
\hline $\mathrm{Ba}$ & 0,055 & $<$ l.d. & 0,051 & 0,22 & 0,7 & 0,056 \\
\hline La & $<$ l.d. & $<$ l.d. & 0,0139 & 0,0075 & 0,097 & 0,031 \\
\hline $\mathrm{Ce}$ & 0,045 & 0,021 & $<$ l.d. & $<$ l.d. & 0,197 & 0,03 \\
\hline $\mathrm{Pr}$ & 0,0061 & $<$ l.d. & 0,0111 & $<$ l.d. & $<$ l.d. & $<$ l.d. \\
\hline Nd & 0,055 & 0,103 & $<$ l.d. & $<$ l.d. & 0,088 & $<$ l.d. \\
\hline Sm & 0,045 & $<$ l.d. & $<$ l.d. & $<$ l.d. & $<$ l.d. & 0,021 \\
\hline $\mathrm{Eu}$ & 0,052 & 0,012 & $<$ l.d. & $<$ l.d. & $<$ l.d. & $<$ l.d. \\
\hline Gd & $<$ l.d. & $<$ l.d. & $<$ l.d. & $<$ l.d. & $<$ l.d. & 0,023 \\
\hline $\mathrm{Tb}$ & $<$ l.d. & $<$ l.d. & 0,032 & 0,014 & 0,0107 & $<$ l.d. \\
\hline Dy & 0,088 & 0,109 & 0,184 & 0,116 & 0,053 & 0,046 \\
\hline Ho & 0,03 & 0,056 & 0,041 & 0,051 & 0,0201 & 0,015 \\
\hline $\mathrm{Er}$ & 0,088 & 0,184 & 0,08 & 0,065 & 0,057 & 0,042 \\
\hline $\mathrm{Tm}$ & 0,029 & 0,061 & $<$ l.d. & $<$ l.d. & 0,0063 & 0,0084 \\
\hline $\mathbf{Y b}$ & $<$ l.d. & 0,133 & $<$ l.d. & 0,187 & 0,21 & 0,113 \\
\hline Lu & 0,078 & 0,044 & 0,043 & 0,085 & 0,0142 & 0,0308 \\
\hline Hf & 0,099 & 0,047 & $<$ l.d. & $<$ l.d. & 0,024 & $<$ l.d. \\
\hline $\mathrm{Ta}$ & 0,017 & $<$ l.d. & $<$ l.d. & $<$ l.d. & 0,0034 & $<$ l.d. \\
\hline $\mathrm{Pb}$ & $<$ l.d. & $<$ l.d. & $<$ l.d. & $<$ l.d. & $<$ l.d. & $<$ l.d. \\
\hline Th & $<$ l.d. & $<$ l.d. & $<$ l.d. & $<$ l.d. & 0,117 & 0,083 \\
\hline $\mathbf{U}$ & $<$ l.d. & 0,0129 & $<$ l.d. & 0,027 & 0,114 & 0,061 \\
\hline
\end{tabular}


Anexo 12: Análises químicas em ortopiroxênio por LA-ICPMS (continuação).

\begin{tabular}{|c|c|c|c|c|c|}
\hline Amostra & KIxm1 & KIxm1 & KIxm1 & KIxm2 & KIxm2 \\
\hline Li & 1,66 & 2,27 & 1,77 & 12,46 & 3,14 \\
\hline $\mathrm{Be}$ & $<$. I.d. & $<$.l.d. & $<$. l.d. & $<$.l.d. & 2,8 \\
\hline Mg & 210513,7 & 210875,59 & 211189,19 & $34,92(\%)$ & $34,21(\%)$ \\
\hline $\mathbf{P}$ & 28,23 & 38,27 & 56,91 & 43,73 & 76,4 \\
\hline $\mathrm{Ca}$ & 3159,24 & 4032,93 & 4777,02 & 5973,09 & 5332,93 \\
\hline Sc & 21,49 & 20,49 & 21,45 & 8,57 & 4,56 \\
\hline $\mathrm{Ti}$ & 87,79 & 80,88 & 86,62 & 1612,95 & 1098,15 \\
\hline v & 94,69 & 93,59 & 95,77 & 42,4 & 30,54 \\
\hline $\mathrm{Cr}$ & 3429,44 & 3527,2 & 3788,67 & 2449,94 & 2335,92 \\
\hline Mn & 1136,34 & 1119,93 & 1160,01 & 1285,34 & 1229,67 \\
\hline Co & 49,39 & 51,39 & 53 & 64,42 & 62,81 \\
\hline $\mathrm{Ni}$ & 604,28 & 651,17 & 641,86 & 833,62 & 853,16 \\
\hline $\mathrm{Cu}$ & 0,38 & 0,6 & 0,41 & 0,85 & 1,55 \\
\hline $\mathrm{Zn}$ & 18,09 & 19,38 & 18,37 & 71,97 & 65,65 \\
\hline $\mathbf{G a}$ & 1,73 & 1,42 & 1,91 & 3,02 & 2,56 \\
\hline $\mathbf{R b}$ & $<$. I.d. & 0,0086 & $<. \mathrm{l} . \mathrm{d}$ & 0,49 & 0,85 \\
\hline $\mathrm{Sr}$ & 0,029 & 0,106 & 0,191 & 0,58 & 6,49 \\
\hline $\mathbf{Y}$ & 0,127 & 0,142 & 0,078 & 0,144 & 0,262 \\
\hline $\mathrm{Zr}$ & 0,035 & 0,0129 & 0,019 & 1,52 & 1,93 \\
\hline $\mathrm{Nb}$ & 0,0117 & 0,043 & 0,032 & $<$.l.d. & $<. I . d$. \\
\hline Mo & $<$. I.d. & $<. l . d$ & 0,044 & $<$. I.d. & $<$. I.d. \\
\hline Sn & 1,15 & 1,06 & 0,91 & $<$.l.d. & $<. I . d$. \\
\hline Sb & $<$. I.d. & $<$ l.d. & $<$. I.d. & $<$.l.d. & 0,051 \\
\hline Cs & $<$. I.d. & 0,0025 & $<. I . d$ & 0,137 & <.l.d. \\
\hline $\mathrm{Ba}$ & $<$. I.d. & 0,022 & 0,044 & 0,11 & 6,32 \\
\hline La & $<$. I.d. & 0,003 & 0,0061 & $<. I . d$ & 0,321 \\
\hline $\mathrm{Ce}$ & $<$. l.d. & $<$. l.d. & 0,0059 & $<$.l.d. & 0,62 \\
\hline Pr & $<$. I.d. & 0,0023 & 0,0047 & $<$. I.d. & 0,071 \\
\hline Nd & $<$. l.d. & 0,041 & $<$. l.d. & $<$.I.d. & $<$.l.d. \\
\hline Sm & 0,017 & 0,016 & 0,017 & 0,53 & $<$.I.d. \\
\hline Eu & 0,026 & $<$.l.d. & $<$. l.d. & 0,026 & 0,045 \\
\hline Gd & $<$. l.d. & 0,037 & $<$. l.d. & 0,12 & 0,2 \\
\hline Tb & $<$. I.d. & $<. I . d$ & $<. l . d$ & $<. I . d$ & $<$.I.d. \\
\hline Dy & $<$. l.d. & $<$ l.d. & $<. l . d$ & 0,058 & $<. l . d$. \\
\hline Ho & 0,0025 & $<. l . d$ & 0,0047 & 0,088 & $<$.I.d. \\
\hline Er & $<$. l.d. & $<. l . d$ & $<. l . d$ & $<$.l.d. & 0,112 \\
\hline $\mathrm{Tm}$ & $<$. l.d. & 0,0197 & 0,0022 & 0,014 & 0,025 \\
\hline $\mathrm{Yb}$ & 0,063 & 0,073 & 0,057 & $<$. I.d. & 0,081 \\
\hline Lu & 0,0258 & 0,0145 & 0,0098 & $<$.l.d. & $<$. I.d. \\
\hline $\mathrm{Hf}$ & 0,035 & $<. l . d$ & 0,017 & $<$. I.d. & $<$.I.d. \\
\hline $\mathrm{Ta}$ & $<$. I.d. & $<$.l.d. & 0,0024 & $<$. I.d. & $<$.l.d. \\
\hline $\mathbf{P b}$ & $<$. l.d. & 0,061 & $<$. l.d. & 0,12 & 0,125 \\
\hline Th & $<$. I.d. & $<. I . d$ & $<$. l.d. & 0,016 & 0,04 \\
\hline $\mathbf{U}$ & <.I.d. & $<$. l.d. & <.I.d. & 0,014 & 0,024 \\
\hline
\end{tabular}


Anexo 13: Análises químicas de elementos traços em cristais de clinopiroxênio de xenólitos do manto de Ubatuba e Monte Carmelo por LA-ICPMS.

\begin{tabular}{|c|c|c|c|c|c|c|c|}
\hline Amostra & Ln9xm1 & Ln9xm1 & Ln9xm1 & Ln9xm1 & Ln9xm2 & Ln9xm3 & Ln9xm3 \\
\hline Li & 1,43 & 1,68 & 10,34 & 3,63 & 104,92 & 2,64 & 4,98 \\
\hline $\mathrm{Be}$ & $<$.l.d. & 1,67 & <.I.d. & <.l.d. & 3,61 & 0,7 & 2,17 \\
\hline Mg & 101117,6 & 98181,42 & 107585,7 & 99073,26 & 141894,3 & 93635,09 & 95657,77 \\
\hline $\mathbf{P}$ & 44,38 & 42,8 & 79,6 & 84,7 & $<$ l.d. & 89,09 & 86,22 \\
\hline $\mathrm{Ca}$ & 157555,8 & 157555,8 & 158456,3 & 158456,33 & 157927,5 & $21,47(\%)$ & $22,8(\%)$ \\
\hline Sc & 68,04 & 65,59 & 62,91 & 65,46 & 43,25 & 55,72 & 58,76 \\
\hline Ti & 1242,17 & 1323,86 & 1236,6 & 962,9 & 1007,49 & 5548,49 & 6065,27 \\
\hline V & 262,51 & 266,71 & 267,59 & 248,97 & 194,6 & 269,06 & 288,83 \\
\hline $\mathrm{Cr}$ & 8261,51 & 7752,04 & 8038,23 & 7502,41 & 3940,09 & 5151,48 & 5614,71 \\
\hline Mn & 588,4 & 591,48 & 615,79 & 588,31 & 1245,55 & 677,07 & 745,24 \\
\hline Co & 25,89 & 23,57 & 24,68 & 20,45 & 31,79 & 18,95 & 18,76 \\
\hline $\mathrm{Ni}$ & 383,09 & 347,9 & 374,18 & 338,22 & 475,64 & 282,32 & 307,16 \\
\hline $\mathrm{Cu}$ & 0,5 & 0,44 & 2,29 & 0,54 & 4,28 & 0,66 & 1,01 \\
\hline $\mathrm{Zn}$ & 29,55 & 23,5 & 21,26 & 10,38 & 34,08 & 4,72 & 6,54 \\
\hline $\mathbf{G a}$ & 3,85 & 4,08 & 3,7 & 2,62 & 12,69 & 4,97 & 5,5 \\
\hline $\mathbf{R b}$ & 0,209 & 0,274 & 0,42 & 0,115 & 19,39 & $<. l . d$ & 0,164 \\
\hline $\mathrm{Sr}$ & 265,39 & 204,43 & 182,77 & 189,23 & 634,33 & 85,99 & 93,85 \\
\hline Y & 8,53 & 8,87 & 8,99 & 8,29 & 50,71 & 18,23 & 18,24 \\
\hline $\mathrm{Zr}$ & 19,01 & 19,94 & 18,33 & 16,53 & 74,95 & 19,7 & 21,27 \\
\hline $\mathrm{Nb}$ & 0,262 & 0,215 & 0,203 & 0,162 & 17,61 & 0,67 & 0,85 \\
\hline Mo & 0,43 & 0,29 & 0,46 & 0,205 & 0,23 & $<. \mathrm{l} . \mathrm{d}$ & $<$.l.d. \\
\hline Sn & 0,9 & 0,5 & $<$ l. d. & 1,13 & 2,03 & $<$ l.d. & $<$ l. d. \\
\hline Sb & $<$. I.d. & $<$.I.d. & 0,109 & $<$. I.d. & $<$ l.d. & $<$.l.d. & $<$.l.d. \\
\hline Cs & 0,027 & 0,019 & 0,03 & 0,0136 & 0,376 & <.l.d. & $<$ l. d. \\
\hline $\mathrm{Ba}$ & 81,24 & 45,59 & 32,81 & 43,41 & 25,36 & 0,049 & $<$.I.d. \\
\hline La & 22,46 & 19,72 & 18,41 & 17,38 & 17,62 & 2,75 & 2,84 \\
\hline $\mathrm{Ce}$ & 32,63 & 28,82 & 28,58 & 28,41 & 80,3 & 7,75 & 9,28 \\
\hline $\mathrm{Pr}$ & 2,54 & 2,54 & 2,05 & 2,37 & 14,33 & 1,31 & 1,53 \\
\hline Nd & 7 & 7,36 & 7,22 & 8,57 & 79,23 & 5,86 & 7,49 \\
\hline $\mathrm{Sm}$ & 1,12 & 1,3 & 1,3 & 1,3 & 18,7 & 2,52 & 2,51 \\
\hline Eu & 0,459 & 0,451 & 0,535 & 0,504 & 6,09 & 0,99 & 0,9 \\
\hline Gd & 1,46 & 1,26 & 1,06 & 1,15 & 14,76 & 2,49 & 2,73 \\
\hline Tb & 0,216 & 0,249 & 0,189 & 0,253 & 2,41 & 0,518 & 0,421 \\
\hline Dy & 1,34 & 1,73 & 1,36 & 1,29 & 12,73 & 3,42 & 4,43 \\
\hline Ho & 0,396 & 0,381 & 0,344 & 0,325 & 1,92 & 0,673 & 0,838 \\
\hline $\mathrm{Er}$ & 0,979 & 1,01 & 1,08 & 0,87 & 4,23 & 1,79 & 2,19 \\
\hline Tm & 0,195 & 0,13 & 0,136 & 0,159 & 0,547 & 0,274 & 0,367 \\
\hline Yb & 1,03 & 0,97 & 1,15 & 1,27 & 3,9 & 1,88 & 2,82 \\
\hline Lu & 0,126 & 0,19 & 0,16 & 0,106 & 0,347 & 0,3 & 0,274 \\
\hline Hf & 0,392 & 0,42 & 0,313 & 0,45 & 0,87 & 0,44 & 0,43 \\
\hline $\mathrm{Ta}$ & $<$. I.d. & 0,01 & 0,0222 & 0,0121 & 0,332 & $<$.l.d. & 0,157 \\
\hline $\mathrm{Pb}$ & 2,9 & 2,41 & 2,37 & 2,46 & 0,82 & 0,315 & 0,49 \\
\hline Th & 3,44 & 2,99 & 2,99 & 2,42 & 0,349 & 0,093 & 0,141 \\
\hline $\mathbf{U}$ & 0,914 & 1,019 & 1,214 & 0,778 & $<$ l.d. & $<$ l.d. & $<$ I.d. \\
\hline
\end{tabular}

Concentrações em ppm. 
Anexo 13: Análises químicas de clinopiroxênio por LA-ICPMS (continuação).

\begin{tabular}{|c|c|c|c|c|c|c|}
\hline Amostra & Ln9xm3 & Ln9xm3 & Ln9xm3 & KIxm1 & KIxm1 & KIxm1 \\
\hline Li & 1,88 & 2,55 & 1,56 & 3,36 & 2,7 & 4,15 \\
\hline $\mathrm{Be}$ & $<. I . d$ & 0,76 & $<$.l.d. & $<. I . d$. & $<$. I.d. & 0,37 \\
\hline Mg & 82837,84 & 91052,98 & 96591,75 & 91654,86 & 102068,4 & 100127,5 \\
\hline $\mathbf{P}$ & 76,88 & 45,45 & 55,74 & 47,78 & 33,78 & 57,6 \\
\hline $\mathrm{Ca}$ & $19,24(\%)$ & $20,88(\%)$ & $21,76(\%)$ & 158485 & 159249,7 & 159249,7 \\
\hline Sc & 53,5 & 60,23 & 59,52 & 81,92 & 81,33 & 70,89 \\
\hline $\mathrm{Ti}$ & 4842,49 & 5259,36 & 5100,33 & 238,18 & 241,35 & 226,37 \\
\hline v & 261,65 & 285,51 & 281,05 & 225,7 & 254,08 & 234,92 \\
\hline $\mathrm{Cr}$ & 5027,44 & 5206,18 & 5092,64 & 6835,69 & 7024,61 & 7496,64 \\
\hline $\mathrm{Mn}$ & 684,6 & 687,88 & 701,56 & 502,35 & 558,06 & 577,62 \\
\hline Co & 18,46 & 19,29 & 20,44 & 14,36 & 15,15 & 17,54 \\
\hline $\mathrm{Ni}$ & 268,31 & 281,2 & 297,62 & 265,57 & 272,34 & 286,56 \\
\hline $\mathrm{Cu}$ & 0,48 & 0,99 & 0,45 & 0,29 & $<. I . d$ & <.l.d. \\
\hline Zn & 5,12 & 7,01 & 8,69 & 3,39 & 5,66 & 5,84 \\
\hline $\mathbf{G a}$ & 4,25 & 4,75 & 4,5 & 1,55 & 1,34 & 1,43 \\
\hline $\mathbf{R b}$ & $<. I . d$ & $<$. l.d. & $<$.I.d. & 0,03 & $<. \mathrm{l} . \mathrm{d}$ & 0,0137 \\
\hline $\mathrm{Sr}$ & 78,39 & 81,29 & 90,07 & 25,42 & 25,12 & 20,04 \\
\hline $\mathbf{Y}$ & 17,28 & 18,02 & 19,47 & 2,29 & 2,08 & 2,21 \\
\hline $\mathrm{Zr}$ & 17,89 & 19,09 & 21,63 & 0,128 & 0,187 & 0,145 \\
\hline $\mathrm{Nb}$ & 0,6 & 0,81 & 0,8 & 0,812 & 0,881 & 0,995 \\
\hline Mo & $<. I . d$ & $<$. I.d. & 0,074 & 0,151 & $<. \mathrm{l} . \mathrm{d}$ & <.l.d. \\
\hline Sn & $<$.l.d. & 1,55 & $<$.l.d. & 0,97 & 0,88 & 0,85 \\
\hline Sb & 0,109 & $<$. l.d. & $<$.l.d. & $<$.l.d. & 0,06 & $<$. I.d. \\
\hline Cs & $<$.l.d. & $<$. I.d. & $<$.l.d. & $<. I . d$ & <.l.d. & $<$.l.d. \\
\hline $\mathrm{Ba}$ & 0,2 & $<$. l.d. & 0,18 & 0,165 & 0,92 & 0,116 \\
\hline La & 2,34 & 2,52 & 2,72 & 1,345 & 1,31 & 1,266 \\
\hline $\mathrm{Ce}$ & 7,6 & 7,5 & 8,3 & 1,262 & 1,183 & 1,085 \\
\hline $\operatorname{Pr}$ & 1,12 & 0,98 & 1,51 & 0,086 & 0,077 & 0,064 \\
\hline Nd & 6,18 & 5,5 & 7 & 0,107 & 0,182 & 0,066 \\
\hline $\mathrm{Sm}$ & 1,27 & 1,73 & 2,03 & $<$.l.d. & $<$. l.d. & 0,017 \\
\hline Eu & 0,73 & 0,65 & 0,71 & 0,0086 & 0,011 & 0,0105 \\
\hline Gd & 2,64 & 2,99 & 3,28 & $<$. I.d. & $<. l . d$ & 0,115 \\
\hline Tb & 0,402 & 0,592 & 0,602 & 0,026 & 0,0105 & 0,0202 \\
\hline Dy & 2,61 & 3,14 & 3,73 & 0,191 & 0,306 & 0,142 \\
\hline Ho & 0,576 & 0,77 & 0,764 & 0,088 & 0,041 & 0,091 \\
\hline Er & 1,75 & 1,71 & 1,92 & 0,247 & 0,41 & 0,248 \\
\hline $\mathrm{Tm}$ & 0,304 & 0,254 & 0,263 & 0,063 & 0,038 & 0,048 \\
\hline Yb & 2,25 & 1,47 & 2,86 & 0,65 & 0,272 & 0,537 \\
\hline Lu & 0,286 & 0,37 & 0,325 & 0,078 & 0,063 & 0,058 \\
\hline $\mathrm{Hf}$ & 0,62 & 0,38 & 0,8 & $<. I . d$ & $<$. l.d. & 0,017 \\
\hline $\mathrm{Ta}$ & 0,11 & 0,033 & 0,083 & 0,0137 & $<. l . d$ & 0,0174 \\
\hline $\mathbf{P b}$ & 0,185 & 0,165 & 0,209 & 0,217 & 0,124 & 0,119 \\
\hline Th & 0,086 & 0,053 & $<$.I.d. & 0,031 & 0,027 & 0,1 \\
\hline U & 0,019 & $<$. l.d. & 0,023 & <.l.d. & $<$. l.d. & 0,093 \\
\hline
\end{tabular}


Anexo 13: Análises químicas de clinopiroxênio por LA-ICPMS (continuação).

\begin{tabular}{|c|c|c|c|c|}
\hline Amostra & Klxm2 & Klxm2 & KIxm2 & KIxm3 \\
\hline Li & 5,91 & 6,96 & 9,74 & 9,46 \\
\hline $\mathrm{Be}$ & $<$ l.d. & $<$ l.d. & $<$ l.d. & $<$ l.d. \\
\hline Mg & 102537,6 & 108524,6 & 108295,2 & 109950,7 \\
\hline $\mathbf{P}$ & 92,52 & 198,17 & 77,67 & 103,56 \\
\hline $\mathrm{Ca}$ & $20,03(\%)$ & $20,14(\%)$ & $19,98(\%)$ & 167175,7 \\
\hline Sc & 47,04 & 51,56 & 56,8 & 73,64 \\
\hline Ti & 2194,08 & 1995,17 & 1960,77 & 1641,42 \\
\hline V & 218,08 & 274,07 & 302,52 & 354,49 \\
\hline $\mathrm{Cr}$ & 6158,44 & 8155,5 & 8729,52 & 2776,3 \\
\hline $\mathrm{Mn}$ & 798,08 & 867,9 & 863,84 & 1072,03 \\
\hline Co & 23,72 & 25,69 & 25,36 & 38,56 \\
\hline $\mathrm{Ni}$ & 381,44 & 375,58 & 387,64 & 383,71 \\
\hline $\mathrm{Cu}$ & $<$ l.d. & 2,2 & $<$ l.d. & 72,35 \\
\hline Zn & 20,93 & 18,11 & 26,22 & 84,23 \\
\hline $\mathbf{G a}$ & 5,52 & 7,02 & 5,74 & 4,63 \\
\hline $\mathbf{R b}$ & 1,5 & 2,86 & 0,96 & 45,91 \\
\hline $\mathrm{Sr}$ & 240,46 & 302,88 & 395,42 & 1298,83 \\
\hline $\mathbf{Y}$ & 6,97 & 6,87 & 6,05 & 17,54 \\
\hline $\mathrm{Zr}$ & 99,43 & 100,15 & 93,71 & 128,9 \\
\hline $\mathrm{Nb}$ & 0,246 & 1,96 & 0,145 & 2,58 \\
\hline Mo & $<$ l.d. & $<$ l.d. & $<$ l.d. & 0,69 \\
\hline Sn & 1,48 & 1,55 & $<$ l.d. & 2,49 \\
\hline Sb & 0,088 & 0,049 & 0,156 & 0,154 \\
\hline Cs & 0,068 & $<$ l.d. & $<$ l.d. & 0,347 \\
\hline $\mathrm{Ba}$ & 58,42 & 72,36 & 22,56 & 80,47 \\
\hline La & 5,18 & 8,09 & 3,48 & 18,77 \\
\hline $\mathrm{Ce}$ & 17,66 & 28,58 & 14,99 & 79,89 \\
\hline $\mathrm{Pr}$ & 3,06 & 4,05 & 2,95 & 13,69 \\
\hline Nd & 18,84 & 22,19 & 17,09 & 65,3 \\
\hline Sm & 4,14 & 5,47 & 4,99 & 13,28 \\
\hline Eu & 0,95 & 1,59 & 0,9 & 3,49 \\
\hline Gd & 1,8 & 3,82 & 3,92 & 8,48 \\
\hline Tb & 0,349 & 0,29 & 0,328 & 1,064 \\
\hline Dy & 1,87 & 2 & 1,91 & 4,3 \\
\hline Ho & 0,268 & 0,213 & 0,101 & 0,752 \\
\hline $\mathrm{Er}$ & 0,64 & 0,65 & 0,69 & 1,54 \\
\hline $\mathrm{Tm}$ & 0,108 & 0,036 & 0,064 & 0,104 \\
\hline $\mathrm{Yb}$ & 0,55 & 0,54 & 0,57 & 0,85 \\
\hline Lu & $<$ l.d. & 0,013 & $<$ l.d. & 0,093 \\
\hline $\mathrm{Hf}$ & 5,41 & 5,54 & 7,1 & 5,75 \\
\hline $\mathrm{Ta}$ & $<$ l.d. & 0,16 & 0,015 & 0,158 \\
\hline $\mathrm{Pb}$ & 0,6 & 0,56 & 0,65 & 6,6 \\
\hline Th & 0,103 & 0,349 & 0,014 & 0,081 \\
\hline $\mathbf{U}$ & $<$ l.d. & 0,044 & $<$ l.d. & $<$ l.d. \\
\hline
\end{tabular}

